\title{
De rol van tutoren in probleemgestuurd onderwijs : contrasten tussen student- en docent-tutoren
}

Citation for published version (APA):

Moust, J. H. C. (1993). De rol van tutoren in probleemgestuurd onderwijs : contrasten tussen student- en docent-tutoren. [Doctoral Thesis, Maastricht University]. Datawyse / Universitaire Pers Maastricht. https://doi.org/10.26481/dis.19930101jm

Document status and date:

Published: 01/01/1993

DOI:

10.26481/dis.19930101jm

Document Version:

Publisher's PDF, also known as Version of record

\section{Please check the document version of this publication:}

- A submitted manuscript is the version of the article upon submission and before peer-review. There can be important differences between the submitted version and the official published version of record.

People interested in the research are advised to contact the author for the final version of the publication, or visit the DOI to the publisher's website.

- The final author version and the galley proof are versions of the publication after peer review.

- The final published version features the final layout of the paper including the volume, issue and page numbers.

Link to publication

\footnotetext{
General rights rights.

- You may freely distribute the URL identifying the publication in the public portal. please follow below link for the End User Agreement:

www.umlib.nl/taverne-license

Take down policy

If you believe that this document breaches copyright please contact us at:

repository@maastrichtuniversity.nl

providing details and we will investigate your claim.
}

Copyright and moral rights for the publications made accessible in the public portal are retained by the authors and/or other copyright owners and it is a condition of accessing publications that users recognise and abide by the legal requirements associated with these

- Users may download and print one copy of any publication from the public portal for the purpose of private study or research.

- You may not further distribute the material or use it for any profit-making activity or commercial gain

If the publication is distributed under the terms of Article $25 \mathrm{fa}$ of the Dutch Copyright Act, indicated by the "Taverne" license above, 
DE ROL VAN TUTOREN

IN PROBLEEMGESTUURD ONDERWIJS 
Promotores:

Prof.dr. H.G. Schmidt

Prof.mr. M.J. Cohen

\title{
Beoordelingscommissie:
}

\author{
Prof.dr. H.F.M. Crombag (voorzitter) \\ Dr. Th.J. ten Cate \\ Prof.mr. G.P.M.F. Mols \\ Prof.dr. W.H.F.W. Wijnen
}

Produktie: Datawyse / Universitaire Pers Maastricht

\section{CIP-GEGEVENS KONINKLIJKE BIBLIOTHEEK, DEN HAAG}

Moust, Jozef Hubertus Christiaan

De rol van tutoren in probleengestuurd onderwijs:

contrasten tussen student- en docent-tutoren /

Jozef Hubertus Christiaan Moust. - Maastricht:

Universitaire Pers Maastricht. - III.

Proefschrift Maastricht - Mct lit. opg. -

Met samenvatting in het Engels.

ISBN 90-5278-066-8

NUGI 724

Trefwoord: doceren / problecmgestuurd onderwijs; hoger onderwijs; onderzoek. 
Voor Margriet, Björn, Nina en Ingmar 
In dit proefschrift wordt een beeld geschetst van de rol van de tutor in probleemgestuurd onderwijs. Omwille van de leesbaarheid is de mannelijke persoonsvorm gebruikt. De auteur is er zich van bewust dat ook vrouwelijke docenten en ouderejaarsstudenten de tutorrol met evenveel plezier, deskundigheid en betrokkenheid vervullen als hun mannelijke collega's. Het zal duidelijk zijn dat overal waar hij of zijn staat ook zij of haar gelezen kan worden. 


\section{Het onderwijs in de Faculteit der Rechtsgeleerdheid}

Inleiding $I$

Kenmerken van probleemgestuurd onderwijs 4

Het probleemgestuurd juridisch curriculum van de Rijksuniversiteit Limburg:

een globale beschrijving 8

De rol van de tutor in probleemgestuurd onderwijs 11

Samenvatting 14

\section{Studenten als docenten in het onderwijs}

Inleiding 15

Overwegingen om studenten als docent in het onderwijs in te schakelen 15

Vormen van studentgeleid onderwijs in het hoger onderwijs 18

Effecten van studentgeleid onderwijs 20

- Effecten van peer teaching 20

- Effecten van peer tutoring 26

- Effecten van begeleiding door studenten binnen de context van probleemgestuurd onderwijs 29

Beperkingen van bovengenoemd onderzoek 33

Verklaringen voor de mogelijke effectiviteit van studentgeleid onderwijs 34

Samenvatting 39

De inhoud van dit proefschrift 39

\section{Globaal overzicht van het onderzoek}

Inleiding 41

Beschrijving van de onderwijsblokken waarin het onderzoek plaatsvond 41

Opzet van het onderzoek 43

Beschrijving van de gebruikte onderzoeksinstrumenten 47

- Instrumentarium ten behoeve van de studenten 47

- Instrumentarium voor de tutoren 49

Samenvatting 50

4 Verschillen in leerprestaties in docentgeleide en studentgeleide onderwijsgroepen. Resultaten van de bloktoetsmetingen

Inleiding 51

Het meten van leerprestaties met behulp van essayvragen 51

Experiment 1: Leerprestaties van de studenten in het blok "Rechtshandeling" 55

- Methode 55

- Resultaten 59

Experiment 2: Leerprestaties van de studenten in het blok "Onrechtmatig gedrag" 61

- Methode 61

- Resultaten 62

Discussie 64

Een nader onderzoek naar de bloktoetsantwoorden door middel van propositie-analyse 66 
Inleiding 66

Bepaling van proposities in de antwoorden op de bloktoetsvragen 66

Propositie-analyse op de bloktoetsantwoorden van het blok "Rechtshandeling" 68

- Methode 68

- Resultaten 68

Propositie-analyse op de bloktoetsantwoorden van het blok "Onrechtmatig gedrag" 70

- Methode 70

- Resultaten 70

Algemene discussie 72

5 Verschillen in besteding van studietijd in studentgeleide en docentgeleide onderwijsgroepen. Resultaten van studietijdmetingen

Inleiding 75

Methoden van studietijdmeting 76

Studietijdbesteding in het blok "Rechtshandeling" 77

- Methode 77

- Resultaten en discussie 78

-* Totaal bestede studietijd 78

- Verschillen in tijdsbesteding tussen studenten begeleid door staf-tutoren en student-tutoren 81

Studietijdbesteding in het blok "Onrechtmatig gedrag" 83

- Methode 83

- Resultaten en discussie 84

-. Totial bestede studietijd 84

- Verschillen in tijdsbesteding tussen studenten begeleid door staf-tutoren en student-tutoren 86

Algemene discussie 88

6 Verschillen in optreden tussen student-tutoren en staf-tutoren. Resultaten van de observatielijst "tutorgedrag"

Inleiding 91

Schets van de tutorrol 92

Verwachtingen van studenten en tutoren van de tutorrol 95

- Verwachtingen die studenten van hun tutor hebben 96

- Verwachtingen van docenten van de tutorrol 98

Kenmerken van tutoroptreden 100

- De kenniscomponent 100

- De relatiecomponent 102

Mogelijke verschillen tussen student-tutoren en staf-tutoren; een eerste verkenning 103

- Verschillen in de mate waarin student-tutoren en staf-tutoren hun expertise gebruiken 104

- Verschillen in de mate waarin student-tutoren en staf-tutoren zich kunnen verplaatsen in de denkwereld van de student 106

- Verschillen in de mate waarin student-tutoren en staf-tutoren gericht zijn op de toets 107

- Verschillen in de mate waarin student-tutoren en staf-tutoren hun autoriteit uitoefenen 108

- Verschillen in de mate waarin student-tutoren en staf-tutoren zich kunnen verplaatsen in de leefwereld van de studenten 109 
- Verschillen in de mate waarin student-tutoren en staf-tutoren aandacht hebben voor de samenwerking in de onderwijsgroep 109

Betrouwbaarheid en validiteit van de observatielijst "tutorgedrag" 110

- Methode 110

- Meetkenmerken van het instrument 113

Verschillen in tutorgedrag tussen student-tutoren en staf-tutoren in het blok

"Rechtshandeling" en "Onrechtmatig gedrag" 117

- Methode 117

- Resultaten 117

Discussie 119

- Verschillen in gebruik van expertise 119

- Verschillen in cognitieve congruentie 121

- Verschillen in de mate van toetsgerichtheid 122

- Verschillen in autoriteit 123

- Verschillen in rolcongruentie 124

- Verschillen in aandacht voor samenwerking 124

Algemene discussie 125

\section{Een causaal model van tutorfunctioneren}

Inleiding 127

Een model van tutorfunctioneren 128

- Methode 131

- Resultaten 132

Discussie 133

Implicaties voor het onderwijs 137

Samenvatting 143

Summary 153

Literatuur 161

\section{Bijlagen}

Bijlage 3.1 Algemene informatie aan de studenten over het onderzoek 169

Bijlage 3.2 Specifieke informatie aan de studenten over het onderzoek 171

Bijlage 4.1 Generaliseerbaarheidsstudies van de bloktoetsen 173

Bijlage 4.2 Propositie-analyses per vraag van de bloktoetsvragen "Rechtshandeling" 175

Bijlage 4.3 Propositie-analyses per vraag van de bloktoetsvragen "Onrechtmatig gedrag" 177

Bijlage 5.1 Voorbeeld van het tijdschrijfregistratieformulier 179

Bijlage 5.2 Introductiebrief behorende bij het tijdschrijfformulier 181

Bijlage 6.1 De vragenlijst "programma-evaluatie' waarin opgenomen de observatielijst 'tutorgedrag' 183

Bijlage 6.2 Generaliseerbaarheidsstudies van de categorieën uit de observatielijst 'tutorgedrag' 191

Dankwoord 195

Curriculum vitae 197 



\section{Het onderwijs in de Faculteit der Rechtsgeleerdheid}

\section{Inleiding}

In 1982 werd aan de Rijksuniversiteit Limburg begonnen met de studierichting Nederlands Recht. De ontwikkelaars van deze opleiding kozen voor de opbouw van het curriculum en voor de vormgeving van het onderwijs dezelfde onderwijskundige uitgangspunten als die ten grondslag lagen aan de Faculteit der Geneeskunde en de Faculteit Sociale Gezondheidkunde (Cohen \& Crombag, 1978; College van Bestuur RL, 1979; Thung, 1980). Deze onderwijskundige uitgangspunten waren gebaseerd op de ideeën van probleemgestuurd onderwijs. Probleemgestuurd onderwijs kan omschreven worden als een benadering van het onderwijsleerproces waarbij studenten kennis verwerven door in een kleine groep te werken aan het begrijpen, eventueel oplossen, van concrete problemen. Die problemen zijn door de docenten geconstrueerd en rond een bepaald centraal thema gegroepeerd. Ieder thema wordt gedurende een blokperiode van zes à acht weken aan de orde gesteld (Reerink, Tiddens \& Wijnen, 1974; Schmidt, 1979).

$\mathrm{Na}$ een start met een jaarlijkse instroom van respectievelijk 100, 200 en 300 studenten, werd de staf van de juridische faculteit in het studiejaar 19851986 geconfronteerd met een instroom van 400 eerstejaarsstudenten. Deze explosieve groei van de studentenaantallen was het gevolg van universitair beleid dat een snelle uitbouw van de universiteit beoogde. Hierdon werd een geleidelijke groei van de faculteit tot een jaarlijkse instroom van maximaal 300 studenten per jaar doorbroken. De Faculteit der Rechtsgeleerdheid werd door deze vergrote instroom van studentenaantallen tamelijk plotseling geconfronteerd met een ongunstiger wordende staf/student ratio. Een staf/student ratio -- het dient gezegd -- die in juridische faculteiten elders gebruikelijk is. 
In de context van probleemgestuurd onderwijs was niet eerder gewerkt met dergelijke grote studentenaantallen en het was onduidelijk of deze onderwijsmethode met een zo grote studentenpopulatie nog wel toegepast kon worden. De Faculteit stond voor de keuze haar onderwijsvormgeving te wijzigen of te zoeken naar wegen waarbij de kleinschaligheid van haar onderwijs gehandhaafd kon worden. Met name het inschakelen van ouderejaarsstudenten in het onderwijs zou een mogelijkheid kunnen bieden om vast te houden aan de onderwijskundige uitgangspunten.

Geconfronteerd met deze keuze ontstonden er in de faculteit twee stromingen. Een gedeelte van de staf was van mening dat het begeleiden van studenten vroeg om een staf die inhoudelijk op wetenschappelijk niveau functioneerde. Men vreesde dat ouderejaarsstudenten niet aan die eis zouden kunnen voldoen, waardoor de faculteit studenten die met student-tutoren geconfronteerd zouden worden zou duperen. Deze groep docenten twijfelde aan de inzetbaarheid van studenten uit de hogere studiejaren op twee gronden. Ten eerste zouden ouderejaars onvoldoende capabel zijn om de interdisciplinaire benadering van het onderwijs te waarborgen, omdat deze vereist dat de begeleidende docent een goed overzicht heeft van de structuur van de verschillende vakgebieden. Naar hun mening ontbrak het ouderejaars nog aan het gewenste overzicht om integratie van leerstof bij de jongerejaarsstudenten te bewerkstelligen. Als tweede argument voerden deze docenten aan dat ouderejaarsstudenten niet beschikken over de specifieke didactische kwaliteiten die noodzakelijk zijn voor een adequate uitvoering van deze docentenrol, bijvoorbeeld het vermogen om inzichtbevorderende vragen te stellen en studenten inzicht te geven in juridische denkwijzen.

De voorstanders van het inschakelen van studenten uit de hogere leerjaren deelden deze bezwaren niet. Immers, zo was hun redenering, de ouderejaars hadden zelf het onderwijs doorlopen waarin ze als docent werkzaam zouden zijn en kenden daardoor beter dan menig staflid de inhoudelijke problemen en moeilijkheden waarmee jongerejaars in dit type onderwijs geconfronteerd zouden worden. Als bijkomend voordeel zagen zij dat de begeleidende ouderejaars beter dan veel stafleden in staat waren te werken met de probleemgestuurde onderwijsmethode. Tenslotte wezen de voorstanders op ervaringen met het inschakelen van ouderejaars elders. Die ervaringen wezen immers uit dat de leerprestaties van studenten begeleid door ouderejaars veelal niet versichilden van studenten begeleid door stafleden (Onderwijscommissie Nederlands Recht-84-I-39).

Uiteindelijk werd door de faculteitsraad besloten studenten uit de hogere studiejaren in te zetten in het onderwijs. De studenten die geselecteerd zouden worden voor het vervullen van docenttaken zouden een deeltijdbenoeming van een dag per week krijgen als student-assistent voor een periode van een jaar. In deze periode moesten zij tijdens verschillende blokperiodes 
een of meer groepjes studenten begeleiden. Zes student-assistenten werden aangetrokken om die taak te vervullen.

Aanvankelijk was de algemene indruk dat deze student-assistenten in de praktijk goed voldeden. Er werd dan ook in eerste instantie niet specifiek onderzocht of de studenten begeleid door de student-assistenten betere, dezelfde of juist mindere leerprestaties behaalden op de toetsen die afgenomen werden aan het einde van elk blok. Enige twijfel aan de effectiviteit van de student-assistenten, wat betreft de leerprestaties van de studenten die zij onder hun hoede hadden, ontstond toen een globale screening van twee onderwijsblokken aantoonde dat in het ene blok de bloktoetsresultaten van studenten begeleid door student-assistenten slechter waren dan de prestaties van de studenten begeleid door stafleden, terwijl in het andere blok beide groepen dezelfde resultaten behaalden. De vraag "halen studenten begeleid door student-assistenten eigenlijk wel dezelfde resultaten op de afsluitende summatieve bloktoets als studenten begeleid door stafleden?" werd nog pregnanter toen via een wat zorgvuldiger uitgevoerd onderzoek in het academisch jaar 1987-1988 in een blok aangetoond werd dat de studenten begeleid door stafleden in dat blok significant betere leerprestaties behaalden dan hun collega's begeleid door student-assistenten (Moust, De Volder \& Nuy, 1989).

Daarmee was de vraagstelling van het onderhavige onderzoek gegeven. Verschillen stafleden van student-assistenten in de wijze waarop ze bijdragen aan het leerproces van studenten en leidt dat tot verschillende leerresultaten?

In het onderzoek dat in dit proefschrift gepresenteerd wordt, is deze vraag van verschillende kanten benaderd. Daar de hierboven genoemde onderzoekjes nogal informeel en post-hoc uitgevoerd werden, leek het verstandig om nog eens, maar nu onder gecontroleerde omstandigheden te onderzoeken of er feitelijke verschillen aangetoond konden worden tussen studieresultaten van studenten begeleid door student-assistenten of stafleden (Hoofdstuk 4). Vervolgens is langs drie wegen geprobeerd een verklaring te vinden voor de aan- of afwezigheid van verschillen in studieprestaties. Nagegaan is of er verschillen waren in studie-inspanning tussen studenten begeleid door ouderejaars en studenten begeleid door stafleden. Daartoe is de hoeveelheid tijd gemeten die studenten aan zelfstudie besteden (Hoofdstuk 5). Vervolgens is nagegaan of, en op welke aspecten, het optreden van ouderejaarsstudenten verschilt van dat van stafleden wanneer zij een groep begeleiden (Hoofdstuk 6). Tenslotte is onderzocht of er relaties gelegd kunnen worden tussen specifieke kenmerken van docentgedrag en de uitkomsten in tijdsbesteding en leerprestaties (Hoofdstuk 7). Ter beantwoording van de vraag hoe stabiel de bevindingen zijn, werd het onderzoek in twee verschillende onderwijsblokken uitgevoerd. 
In dit hoofdstuk zal ter inleiding aandacht besteed worden aan de kenmerken van probleemgestuurd onderwijs, de wijze waarop deze onderwijsbenadering vorm heeft gekregen in de Faculteit der Rechtsgeleerdheid en de taken van de tutor, de docentenrol die in dit onderzoek een centrale rol speelt.

\section{Kenmerken van probleemgestuurd onderwijs}

Probleemgestuurd onderwijs is een tamelijk nieuwe onderwijsvorm, die gesitueerd kan worden in het verlengde van onderwijsmethoden als de "case study method" en "learning by discovery' (Schmidt, 1982).

De case study method (de gevalsmethode), volgens Crombag (1972) door Langdell omstreeks 1870 ontwikkeld aan Harvard Law School, is "een onderwijssysteem, waarbij studenten tot juristen worden opgeleid door hen cases te laten lezen, analyseren, bediscussiëren en kritiseren" (Crombag, 1972, p. 127). Langdell ontwikkelde deze methode omdat hij ontevreden was met het feit dat de juridische studenten, in zijn tijd, de verschillende juridische doctrines moesten memoriseren uit de handboeken. Volgens Langdell had onderwijzen met behulp van de case study method verschillende voordelen ten opzichte van bestudering van het rechtsstelsel via handboeken. Crombag noemt drie redenen op grond waarvan Langdell tot de ontwikkeling van deze methode kwam. Ten eerste zouden studenten de juridische doctrines beter onthouden wanneer ze aangespoord zouden worden de rechtsregels zélf te destilleren uit de cases, dan wanneer studenten deze doctrines passief zouden memoriseren uit handboeken. Langdell ging er vanuit dat actief leren effectiever is dan passief leren. Ten tweede zouden studenten door deze werkwijze tijdens hun studie eerder ontdekken dat het juridisch domein geen vaststaand systeem van doctrines is, maar een systeem dat voortdurend in ontwikkeling is. De gevalsmethode had het voordeel, dat men de student tijdens het onderwijs voortdurend met die ontwikkelingen kon confronteren. Ten derde zou de methode het (empirisch-inductieve) wetenschappelijke karakter van de juridische studie benadrukken. Hoewel Langdell de case method vooral zag als een effectieve methode om zijn studenten kennis van het recht bij te brengen, beschouwden zijn navolgers de methode vooral als een werkwijze waarmee de studenten een bepaalde vaardigheid, namelijk "reasoning power" konden leren. Het accent bij het gebruiken van deze methode verschoof daardoor langzamerhand steeds meer in de richting van het toepassen van, op een andere wijze verworven, kennis. Studenten bestuderen bijvoorbeeld eerst via colleges en handboeken de juridische doctrines en rechtsregels om daarna hun nieuw verworven kennis te testen op aangeboden cases.

Bruner (1961) ontwikkelde een methode, learning by discovery (ontdekkend leren), waarbij hij leerlingen confronteerde met problemen die zij moesten oplossen door middel van discussie met medeleerlingen. Kern van het ontdekkend leren is dat de leerling de kennis, die hij nodig heeft voor het 
oplossen van het probleem, zélf uitvindt; hij produceert als het ware zelf nieuwe feiten, regels en principes terwijl hij aan het probleem werkt. Bruner stelde deze "ontdekkende" aanpak van het leren tegenover wat hij ziet als het passief opslaan van feiten die voor de leerlingen arbitrair zijn. Warries (1977) observeerde dat "Kennis verwerven (...) door Bruner niet (wordt) opgevat als het registreren van informatie en als het overnemen en zonder meer opnemen van door anderen gestructureerde kennis ... Echt leren is voor Bruner bij uitstek een actieve aangelegenheid, waarin de mens zelf bezig is informatie uit de buitenwereld op een bepaalde manier op te vatten, te transformeren en in te passen in zijn eigen cognitieve arsenaal" (pp. 213-214).

Volgens Bruner leidt ontdekkend leren tot grotere intellectuele mogelijkheden bij lerenden, bevordert het de intrinsieke motivatie tot leren en stimuleert het het leren van informatie die betekenisvol is en daarom beter onthouden wordt. Ook zou de methode de transfer van kennis bevorderen. Bruners ideeën worden echter door empirisch onderzoek nauwelijks ondersteund (Shulman \& Keislar, 1966; Wittrock, 1966). Schmidt (1981) stelt, in navolging van Mayer (1975), dat deze teleurstellende resultaten waarschijnlijk verklaard kunnen worden uit het feit dat ontdekkend leren slechts leidt tot activatie van bestaande kennis en dat onvoldoende leren kan plaatsvinden doordat er geen confrontatie met nieuwe kennis plaats heeft. Schmidt (1981) merkt hierover op dat "... geactiveerde voorkennis tijdens het leren moet interacteren met nieuwe informatie om nieuwe kennisstructuren te lalen ontstaan. Aan deze laatste voorwaarde wordt bij ontdekkend leren veelal niet voldaan. De lerende wordt geacht al werkend aan een probleem zelf de noodzakelijke nieuwe informatie te produceren. Het is echter onaannemelijk dat lerenden in staat zouden zijn alle principes, processen of mechanismen die ten aanzien van een bepaald vakgebied relevant zijn, te ontdekken zonder hulp van buitenaf" (p. 9).

Samenvattend kan gesteld worden dat beide onderwijsmethoden, de gevalsmethode en het ontdekkend leren, zich kenmerken door de idee dat studenten in het onderwijs gestimuleerd moeten worden op een actieve wijze kennis te verwerven. Dit lukt beter wanneer het onderwijs als betekenisvol ervaren wordt. Dit gebeurt door de studenten al vroegtijdig in hun studie te confronteren met probleemsituaties waarmee ze later, in hun beroep of leven, ook te maken kunnen krijgen. In de case study method krijgen de studenten probleembeschrijvingen, ontleend aan hun latere beroepsveld, veelal na een periode van studie, voorgelegd. Deze casus moeten ze analyseren, waarna ze eventueel nog relevante informatie verzamelen en oplossingen formuleren. Het toepassen van reeds verworven kennis staat in deze benadering centraal. Bij de methode van het ontdekkend leren wordt, nauw aansluitend aan het cognitieve ontwikkelingsstadium waarin de lerende zich bevindt, uitgegaan van het kennisbestand waarover de leerlingen op dat moment beschikken. 
Probleemgestuurd onderwijs kenmerkt zich door een versmelting van beide onderwijsmethoden. Enerzijds wordt binnen probleemgestuurd onderwijs, veelvuldig gewerkt met gevalsbeschrijvingen, ontleend aan de methodiek van de case study method. Anderzijds worden de studenten gestimuleerd, analoog aan de methode van het ontdekkend leren, hun voorkennis bij de analyse van een casus naar voren te brengen. Kenmerkend voor probleemgestuurd onderwijs is echter dat studenten daarna expliciet in aanraking worden gebracht met nieuwe -- niet door hen zelf geproduceerde -- informatie, die relevant is ten aanzien van het probleem waaraan gewerkt wordt.

Probleemgestuurd onderwijs kan beschouwd worden als een onderwijsarrangement waarin verschillende onderwijskundige, onderwijspsychologische en pedagogische ideeën geïntegreerd worden (Schmidt, 1979). Onderstaand worden kort díe kenmerken van deze onderwijsmethode beschreven die in het kader van deze studie van belang zijn.

De onderwijskundige component van probleemgestuurd onderwijs komt vooral tot uiting in de wijze waarop het curriculum is ingericht. Het onderwijs wordt niet meer gegeven door studenten parallel of sequentieel een of meerdere vakgebieden aan te bieden, maar via een thematische benadering. De studenten krijgen binnen een afgegrensde periode één bepaald thema aangeboden, waarop alle onderwijsactiviteiten gericht zijn. Binnen het onderwerp dat de studenten wordt aangeboden worden gelijktijdig twee of meer vakgebieden op geïntegreerde wijze aan de orde gesteld. Deze benadering is erop gericht "de student ertoe te brengen om vanuit de werkelijkheid ... de begrippen en methoden van relevante wetenschappelijke disciplines te 'ontdekken'" (Thung, 1980, p. 9). Binnen deze themavelden krijgen de studenten practische en theoretische problemen voorgelegd waarmee beroepsbeoefenaren frequent in aanraking komen. Door deze vroegtijdige confrontatie met problemen wordt de student geoefend in "het herkennen van de wetenschappelijke ingangen naar een probleem, het identificeren van de mogelijkheden en grenzen der verschillende disciplines, en het opzoeken en hanteren der juiste bronnen respectievelijk het toepassen van het daar gevondene" (Thung, 1980, p. 9). Met het uitzetten van deze leerweg: "van concrete problemen naar vakspecifieke begrippen en verbanden" wordt beoogd dat de lerende de kennis die hij verworven heeft voortdurend opnieuw gebruikt, waardoor deze beter beklijft en gemakkelijker gegeneraliseerd kan worden naar verwante probleemsituaties en kennisgebieden.

Karakteristiek voor de onderwijspsychologische component van probleemgestuurd onderwijs is de wijze waarop het onderwijsleerproces vorm is gegeven. Studenten werken in een kleine groep aan de problemen -- vaak taken genoemd -- die hen door de staf worden aangereikt. De eerste stap van het leerproces bestaat uit een analyse van de taak op basis van het kennisbestand waarover de groepsleden op dat moment beschikken. Tijdens dit analysepro- 
ces wordt de studenten min-of-meer duidelijk wat zij reeds (menen te) weten en waar lacunes in hun kennis aanwezig zijn. Deze leemtes zijn vervolgens het startpunt voor het verwerven van nieuwe kennis via literatuurstudie, het raadplegen van audio-visueel materiaal of het consulteren van vakdeskundigen. Na een periode van studie komen de studenten weer bijeen om de informatie die zij verworven hebben onderling uit te wisselen, onduidelijkheden in het studiemateriaal te verhelderen, verbanden in de leerstof toe te lichten en hun nieuw verworven kennis toe te passen op de reeds eerder geanalyseerde of analoge taken (Schmidt, 1983). Het leerproces dat de studenten op deze wijze doormaken sluit nauw aan bij hedendaagse leerpsychologische opvattingen over leren als een actief, constructief, cumulatief en doelgericht proces (Shuell, 1986). Ten eerste, wordt gepoogd nauw aan te sluiten bij de voorkennis waarover de student beschikt. Door deze voorkennis te (re)activeren worden gemakkelijker ankerpunten voor het onthouden van de nieuw verworven informatie verkregen (Mayer, 1979). Ten tweede worden de studenten in de gelegenheid gesteld de leerstof, al discussiërend, frequent te structureren en zonodig te herstructureren. Hierdoor worden cognitieve bewerkingsprocessen als elaboratie en organisatie van kennis bevorderd (Anderson \& Reder, 1979; Levin, 1988; Mayer, 1980). Door, ten derde, theoretische en practische probleemsituaties tijdens zijn studieperiode te analyseren en te bestuderen kan de student gemakkelijker een verband leggen tussen de leersituatie en de situaties die de student in zijn latere beroepsveld tegen kan komen. Door het aanbieden van een juridisch thema en probleemsituaties die binnen dit thema veelvuldig voorkomen wordt bevorderd dat de studenten leren binnen een doelgerichte context (Bereiter \& Scardamalia, 1989; Bransford \& Johnson, 1972; Jones, 1991; Schoenfeld, 1989). Deze verschillende leerprincipes bevorderen het onthouden en terughalen van het geleerde (Schmidt, Foster \& Bouhuijs, 1989). Ten slotte, blijkt de intrinsieke motivatie tot leren toe te nemen doordat de studenten, discussiërend over reële problemen, geïnvolveerd raken in een bepaald onderwerp en er meer vanaf willen weten (Schmidt, 1982).

Kenmerkend voor de onderwijspedagogische optiek van probleemgestuurd onderwijs is de grote nadruk die gelegd wordt op de rol van de student in het leerproces. Van de studenten wordt verwacht dat zij een aantal activiteiten, die gewoonlijk door de docent in het onderwijs-leerproces worden uitgevoerd, geheel of gedeeltelijk overnemen. Zo wordt aan de studenten niet meer exact voorgeschreven wat ze moeten bestuderen en welke bronnen ze daarvoor moeten raadplegen. De studenten krijgen een grotere invloed op de keuze van de leerstof en de wijze waarop en wanneer deze bestudeerd wordt. De studenten moeten bovendien veelvuldig aan elkaar informatie overdragen, elkaar bevragen, elkaar feedback geven. Door aan de student meer invloed toe te kennen met betrekking tot wat er bestudeerd moet worden en hoe de student dat wil doen, hoopt men dat de zelfwerkzaamheid van de student bevorderd 
wordt en dat de student zelf meer verantwoordelijkheid gaat dragen voor zijn eigen leerproces. Doordat de student zelf richting kan geven aan wat hij belangrijk en interessant vindt zal de student zijn leerproces zelf meer gaan reguleren en sturen. Verondersteld wordt dat dit proces van "self-directed learning" (Knowles, 1975) ertoe leidt dat de lerende zichzelf primair verantwoordelijk gaat leren voelen voor het plannen, uitvoeren en evalueren van zijn leerweg. Tevens wordt verwacht dat de student door de grotere invloed die hij heeft op zijn leren eerder zal ontdekken dat zijn vorming niet eindigt bij het afsluiten van zijn studieperiode maar dat hij zich tijdens zijn hele (beroeps)-leven zal moeten scholen en bijscholen.

\section{Het probleemgestuurd juridisch curriculum van de Rijksuni- versiteit Limburg: een globale beschrijving}

Het onderwijsprogramma van de juridische faculteit beslaat een tijdspanne van vier jaar. De eerste twee en een half jaar omvatten 10 blokperiodes en een aantal zogenoemde onderwijsvrije periodes waarin de studenten telkens een juridisch opstel moeten schrijven. Elke blokperiode duurt acht weken. In het programma staan niet de juridische vakgebieden centraal maar juridische probleemgebieden of thema's. Als uitgangspunt voor de keuze van de thema's is gekozen voor een ordening rond terreinen waarop mensen actief zijn en een aantal centrale juridische begrippen die een zodanige reikwijdte hebben dat zij de juridische werkelijkheid op wezenlijk transdisciplinaire wijze ordenen (Thung, 1980). Voorbeelden van terreinen waarop mensen actief zijn zijn "huisvesting", "arbeid" en "bedrijf". Voorbeelden van thema's gebaseerd op transdisciplinaire juridische begrippen zijn: "onrechtmatig gedrag" en "rechtshandhaving". Tabel 1.1 geeft een overzicht van de blokthema's in het curriculum van het studiejaar 1988-1989.

Tabel 1.1

Blokthema's curriculum Faculteit der Rechtsgeleerdheid, RL, studiejaar 1988-1989

\begin{tabular}{llll}
\hline $\begin{array}{l}\text { Inleiding studie } \\
\text { Nederlands Recht }\end{array}$ & $\begin{array}{l}1.2 \\
\text { Overheid }\end{array}$ & $\begin{array}{l}1.3 \\
\text { Rechtshandeling }\end{array}$ & $\begin{array}{l}1.4 \\
\text { Onrechtmatig } \\
\text { gedrag }\end{array}$ \\
$\begin{array}{l}2.1 \\
\text { Rechtshandhaving }\end{array}$ & $\begin{array}{l}2.2 \\
\text { Recht, Markt, Staat }\end{array}$ & $\begin{array}{l}2.3 \\
\text { Criminaliteit }\end{array}$ & $\begin{array}{l}2.4 \\
\text { Huisvesting }\end{array}$ \\
3.1 & 3.2 & $\begin{array}{l}3.3 \mathrm{t} / \mathrm{m} \\
\text { Keuzevakken }\end{array}$ & 4.4 \\
\hline
\end{tabular}


In ieder blok worden onderwerpen afkomstig uit verschillende vakgebieden op een min of meer geïntegreerde wijze aangeboden. Binnen het thema "Rechtshandhaving" (het eerste blok uit het tweede studiejaar) krijgen de studenten bijvoorbeeld de volgende subonderwerpen aangeboden: Het recht in eigen hand, burgerlijke rechtspraak, strafrechtspraak, rechtsbescherming tegen de overheid, voorkomen en genezen, executie en sancties, bijzondere onderwerpen, o.a. rechtshulp, het grondrecht op behoorlijke rechtspraak, administratiefrechtelijke afdoening van verkeersovertredingen.

Deze onderwerpen worden aan de orde gesteld in het "blokboek". Het blokboek is een soort werkboek, waarin naast een inleiding, huishoudelijke informatie en literatuursuggesties, taken zijn opgenomen die het leerproces van de studenten moeten activeren en richtinggeven. De taken worden gepresenteerd in de vorm van problemen, situatiebeschrijvingen, stellingen, studieopdrachten of citaten uit de literatuur. Tabel 1.2 geeft een voorbeeld van een taak uit het blok "Rechtshandeling" van het eerste studiejaar.

Tabel 1.2

Taak uit het blok "Rechtshandeling"

Caesar is een pitbull terriër. Het is een aardige hond, vindt zijn baas. Postbodes, SRV-melkboeren, Jehova's getuigen en collectanten denken daar bepaald anders over. Zijn baas weet dat. Desondanks laat hij Caesar vrij rond lopen in zijn (goed omheinde) tuin. Hij vindt namelijk dat iedereen die bij hem aan de deur komt, dat op eigen risico doet.

Op zckere dag gaat het weer mis. De collectante van de dierenbescherming is nog maar net het poortje aan de straatzijde van de voortuin gepasseerd, of Caesar bijt zich vast in haar linkeronderbeen. Pas vijftien minuten later kan de collectante bevrijd worden.

De kosten van de medische behandeling en de beschadigde kleding (totaal fl. $1.250,-)$ worden vergoed door de W.A.-verzekering van Caesars baas. Hij verlangt wel dat de collectante een verklaring ondertekent waarin zij accoord gaat met de betaalde schadevergoeding en afstand doet van alle verdere aanspraken ten opzichte van Caesars baas en diens verzekeraar. Aldus geschiedt.

Een half jaar later krijgt de collectante last van haar linkerbeen. Volgens de doktoren is Caesar zonder twijfel de bron van deze klachten. De collectante moet geopereerd worden. De kosten bedragen meer dan f]. $20.000,00$.

auteur W. Beurskens

De taken uit een blokboek worden in eerste instantie behandeld in een onderwijsgroep, een groep van ongeveer tien studenten. Gedurende de duur van een blok komen de studenten twee maal twee uur per week in een dergelijke groep bijeen. Elke onderwijsgroepsbijeenkomst bestaat uit twee activiteiten: 
de analyse van nieuwe taken en de uitwisseling en synthese van informatie die studenten door zelfstudie verworven hebben. De gebruikelijke gang van zaken bij het behandelen van een nieuwe taak is dat de onderwijsgroepsleden eerst bepalen welk probleem of problemen uit de taak "naar voren springen".

Vervolgens discussiëren ze op basis van hun voorkennis over de geformuleerde probleemstellingen. Ze trachten verklaringen of oplossingen te bedenken voor de verschijnselen of problemen die in de taak beschreven staan. $\mathrm{Ze}$ proberen, als het ware hardop denkend, hun tot dan toe verworven kennis en ervaringen te activeren en toe te passen. Deze analyse dient uit te monden in een min of meer gesystematiseerde inventarisatie van de belangrijkste verklaringen en ideeën. Tijdens de analyse kunnen ideeën, hypothesen en opvattingen die de studenten in de discussie inbrengen onduidelijk of onaf zijn. Vaak is hun voorkennis immers niet voldoende om alle verschijnselen, beschreven in de taak, te verklaren. Studenten kunnen ook geheel verschillende verklaringen aandragen voor hetzelfde fenomeen of een bepaalde veronderstelling bekritiseren. De groepsleden kunnen dan beslissen de gerezen onduidelijkheden en conflicterende ideeën nader in de literatuur te gaan onderzoeken.

Om het studieproces richting te geven, formuleren de leden van de onderwijsgroep vraagstellingen, "leerdoelen" geheten, waarop ze antwoorden proberen te vinden. Aan de hand van deze leerdoelen bestuderen de studenten in de periode tussen twee bijeenkomsten literatuur, bekijken audio-visueel materiaal of raadplegen vakinhoudelijk gespecialiseerde docenten.

Enige dagen na de eerste bijeenkomst komen de groepsleden weer bijeen voor een tweede bespreking van dezelfde taak, maar nu tegen de achtergrond van de kennis die ze in de tussenliggende periode verworven hebben. Tijdens deze bespreking, de zogeheten rapportagefase, bespreken de groepsleden welke informatie zij gevonden hebben naar aanleiding van de leerdoelen en wat tijdens de fase van zelfstudie onduidelijk is gebleven. Gepoogd wordt tegenstrijdigheden, gevonden in de literatuur, te verhelderen en niet door allen begrepen onderdelen van de stof uit te leggen aan elkaar. Daarbij gaat het vooral om greep te krijgen op de onderliggende structuur van de leerstof en het kunnen toepassen van de verworven kennis. Met andere woorden: er wordt nagegaan of men het in de taak beschreven probleem nu beter begrijpt. Eventueel kan ook de vraag aan de orde komen hoe men het betreffende probleem nu zou aanpakken. Deze rapportage ontleent zijn belang vooral aan het feit dat ook na bestudering van leerstof onduidelijkheden blijven bestaan bij de studenten: wetgeving en jurisprudentie, zijn immers niet altijd eenduidig te interpreteren en de studenten hebben verschillende, elkaar soms tegensprekende bronnen, geraadpleegd. Tijdens de rapportagefase blijkt dat de studenten vaak nog problemen hebben om samenhang binnen de leerstof te onderkennen en relevante van irrelevante informatie van elkaar te scheiden. Verbanden tussen rechtsregels worden soms verkeerd gelegd of niet onderkend. Het 
aandragen van voorbeelden of het toepassen van de net verworven kennis op de situatie beschreven in de blokboektaak verloopt soms moeizaam. In deze fase kunnen de leden van de onderwijsgroep elkaar helpen deze onduidelijkheden te verhelderen.

De discussies in de onderwijsgroep worden, bij toerbeurt, geleid door één van de groepsleden. De gespreksleider heeft als taak de voortgang van de groep bij het werken aan de taken te bevorderen. De gespreksleider vervult daartoe in de onderwijsgroep twee soorten activiteiten: taakgerichte en groepsgerichte activiteiten. De taakgerichte activiteiten zijn bedoeld om het verwerven van inhoudelijke informatie te bevorderen, de groepsgerichte activiteiten zijn bedoeld om de samenwerking en het ontwikkelen van de onderlinge relaties te stimuleren (Moust, Bouhuijs \& Schmidt, 1989).

Om een actieve leerhouding te bevorderen wordt aan de leden van een onderwijsgroep een bepaalde mate van zelfwerkzaamheid en autonomie toegekend. Dit betekent dat studenten invloed kunnen uitoefenen op wat er bestudeerd wordt, met welke diepgang, in welke volgorde en in welk tempo. Al discussiërende met elkaar over de taak en de leerstof nemen studenten een aantal onderwijsfuncties over, die in conventioneel onderwijs door een docent worden vervuld (zoals bijvoorbeeld het structureren van de leerstof, vragen stellen, leerdoelen bepalen en voorbeelden bedenken). Studenten worden in de onderwijsgroep min-of-meer hun eigen en elkaars docent. In de dagelijkse praktijk van het onderwijs wordt deze leervrijheid natuurlijk ingeperkt naarmate de bereidheid en het vermogen van de studenten om zelfstandig te leren kleiner is, en door de invloed die de begeleidende docent uitoefent. Daarnaast kan ook de structuur van het blokboek, het aantal taken dat in een blokperiode behandeld moet worden, de wijze waarop aan de taken vorm is gegeven en de bloktoets het leren in en buiten de onderwijsgroep beïnvloeden.

Toetsing van de leerprestaties van de studenten vindt plaats met behulp van een bloktoets. Deze toets bevat een aantal essayvragen over de inhoud van het blok. Met behulp van vooraf vastgelegde normen wordt bepaald of studenten naar een hoger studiejaar kunnen doorstromen.

\section{De rol van de tutor in probleemgestuurd onderwijs}

Het meer centraal stellen van de zelfwerkzaamheid en eigen verantwoordelijkheid van de student heeft consequenties voor de wijze waarop docenten aan het onderwijs vorm kunnen geven. De leeromgeving van de studenten moet zodanig worden ingericht dat een aantal onderwijstaken, die gewoonlijk door de docent worden vervuld, nu grotendeels door studenten zelf worden uitgevoerd. Het zal echter duidelijk zijn dat studenten die voor het eerst in een leersituatie geplaatst worden waarin een grote mate van autonomie van hen verlangd wordt, hiermee moeilijkheden kunnen ondervinden. Veel leden van een onderwijsgroep zijn nog nauwelijks vertrouwd met leersituaties waar- 
bij zij "het heft in handen" mogen nemen. Ze hebben nog geen of weinig ervaring en deskundigheid kunnen opbouwen met het onderwijzen van elkaar.

Om de studenten te helpen bij het verwerven en verwerken van de leerstof wordt daarom iedere onderwijsgroep begeleid door een docent. Deze docent wordt in de context van probleemgestuurd onderwijs de "tutor" genoemd. Barrows (1985) omschrijft de functie van de tutor als volgt: "the skill of the tutor is to make leaming student-centered instead of teacher-centered; facilitating instead of dispensing knowledge" (p. 93). Het handelen van de tutor is volgens Barrows meer gericht op het mogelijk maken van leergedrag van de student dan op het direct onderwijzen van de student. De bijdragen van een tutor moeten dan ook op zodanige wijze naar voren worden gebracht dat ze de autonomie van de studenten niet aantasten en hun zelfwerkzaamheid bevorderen. Barrows benadrukt dat deze "faciliterende" opstelling van de tutor geenszins betekent dat de tutorrol een passieve opstelling van de docent inhoudt. "The tutor is very active in terms of the process involved in problem-based learning" (p. 93). De tutor moet voortdurend nadenken hoe hij leerfuncties die veelal door de docent worden vervuld in handen kan geven van de studenten. Dit faciliteren van het leren kan de tutor, volgens Barrows, het gemakkelijkst realiseren door "nondirective comments" (p. 94) te leveren. Dit zijn vraagstellingen als "wat denk je er zelf van?", "waarom denk je dat dat juist is?" of "heeft iemand anders daar een andere opvatting over?" Barrows (1988) benadrukt als belangrijkste taak van de tutor zijn metacognitieve functie: de tutor moet de studenten bewust maken hoe zij, via reflectie op hun denkwijzen, inzicht krijgen in hun eigen denkproces en de denkpatronen die in hun professie bruikbaar zijn. Naast deze taak ziet Barrows ook nog taken weggelegd voor de tutor op het gebied van het ontwikkelen van een methodische werkhouding van de studenten en het groepsproces.

Ook Schmidt en Bouhuijs (1980) geven enkele manieren aan waarop tutoren het leerproces van studenten kunnen stimuleren: door het tonen van aandacht, door in een groepsdiscussie bewust de rol van advocaat van de duivel op zich te nemen, door afwijkende, het denken van de studenten provocerende standpunten in te nemen en door het stellen van stimulerende vragen. Naast deze meer op het leerproces van de studenten gerichte activiteiten vervult de tutor ook een taak ten aanzien van de samenwerking tussen de studenten. In een leersituatie die slechts gedeeltelijk gestructureerd is en een zekere mate van eigen invulling van persoonlijke interesses biedt, is onderlinge afstemming en samenwerking een delicate maar noodzakelijke aangelegenheid. De onderwijsgroepsleden worden soms heen en weer geslingerd tussen individuele en gemeenschappelijke belangen; ze zien niet altijd de relevantie van de aangeboden taken of worden beïnvloed door persoonlijke sympathieën en antipathieën. Volgens Schmidt en Bouhuijs (1980) kan een tutor de samenwerking tussen de studenten bevorderen door tijdens de eerste bijeenkomst(en) structuur aan te brengen in de groepsactiviteiten en door zelf 
voorbeelden te geven hoe groepsleden met elkaar moeten samenwerken, bv. door aandachtig te luisteren of door iemand te laten uitspreken. Daarnaast kan de tutor de gespreksleider ondersteunen of zelf als gespreksleider optreden, hij kan erop toezien dat de groep hard en geconcentreerd werkt volgens de voorgeschreven procedures en tenslotte kan hij pogingen doen om conflicten die in de groep ontstaan, op te lossen. Alblas (1983) noemt twee gebieden waarop een tutor zijn begeleidende rol ten dienste kan stellen van de groep en de student-gespreksleider: de taakgerichte leiding en de groepsgerichte begeleiding. De taakgerichte leiding betreft de gemeenschappelijke doelstelling van de groep. Het betreft hier alle sturende en bijsturende handelingen die de kwaliteit van de taakverrichting vergroten, bijvoorbeeld voorbereiding en agendering van de taken en leerdoelen, verbeteren van procedures van taakbehandeling, vergroten van de onderlinge informatie-uitwisseling en verwerking, zorgen voor een zorgvuldige afweging van ingebrachte verklaringen en oplossingen en het overzichtelijk en doelgericht houden van de informatie. De groepsgerichte begeleiding bestaat uit alle sturende en bijsturende handelingen die de onderlinge relaties handhaven of verbeteren, zodat de groep als een samenwerkende eenheid kan blijven functioneren. Hiertoe rekent Alblas activiteiten als het signaleren en bespreekbaar maken van latente spanningen en de communicatie tussen de groepsleden openhouden.

De tutor heeft dus een dubbele faciliterende rol. Hij moet de inhoudelijke en procesmatige voortgang van de onderwijsgroep bevorderen. De bijsturende handelingen van de tutor moeten gericht zijn op de wijze waarop de groepsleden informatie verwerven en verwerken en op de wijze van samenwerking in de groep. De mate waarin de tutor hierin slaagt is echter mede afhankelijk van de mate van zelfstandigheid van de groepsleden.

Docenten worden voorbereid op de tutorrol via een tutortraining, waarin door middel van simulatie-oefeningen, videomateriaal en practische suggesties een beeld wordt gegeven van de wijze waarop ze het beste hun rol kunnen uitoefenen (Moust \& Schmidt, 1989). Van alle facultaire stafleden wordt verwacht dat zij, als "docenten-in-het-recht" over voldoende algemene juridische kennis en vaardigheden beschikken om gedurende de studie adekwaat mede inhoud en richting te geven aan het leerproces. Afhankelijk van de inhoud van het blok dat de studenten wordt aangeboden en het vakgebied waarin de tutor zich gespecialiseerd heeft, kan de expertise van de tutoren variëren. Omdat onderwijsblokken kennis en inzichten uit meerdere vakgebieden integreren, zullen tutoren op het ene vakgebied meer expertise bezitten dan op andere vakdomeinen. Zo wordt bijvoorbeeld in het blok "Rechtshandeling" de rechtshandeling zowel binnen het privaatrecht als binnen het administratief recht aan de orde gesteld. En in het blok "Onrechtmatig gedrag" komt dergelijk gedrag aan de orde zowel vanuit strafrechtelijk perspectief als vanuit de privaatrechtelijke invalshoek. Docenten verbonden aan de vakgroep privaatrecht zullen in het algemeen deskundiger zijn met betrekking tot de 
privaatrechtelijke aspecten van deze onderwijsblokken dan met betrekking tot de publiekrechtelijke of strafrechtelijke facetten. Voor publiek- of strafrechtelijk gespecialiseerde tutoren geldt het omgekeerde. Naast juristen kunnen ook andere wetenschappelijke medewerkers als tutor in een onderwijsblok optreden. Voorafgaande aan, en tijdens, de blokperiode is er wekelijks tutorenoverleg. Tijdens dat overleg bespreken de makers van het blokboek en de tutoren de gang van zaken in de onderwijsgroepen. Tevens beschikken de tutoren over schriftelijke achtergrondinformatie over de taken.

\section{Samenvatting}

In dit hoofdstuk is allereerst het dilemma geschetst waarmee de studierichting Nederlands Recht verbonden aan de Rijksuniversiteit Limburg enkele jaren na haar ontstaan, geconfronteerd werd. Dat dilemma werd veroorzaakt door een grote instroom van eerstejaarsstudenten en kan als volgt worden geformuleerd: blijft de probleemgestuurde onderwijsmethode uitvoerbaar wanneer een deel van de onderwijstaken overgedragen wordt aan student-assistenten? Om een inzicht te geven in de problematiek werd vervolgens de wijze besproken waarop het juridisch onderwijs in Maastricht vorm wordt gegeven. Eerst werden een aantal wezenlijke algemene kenmerken van probleemgestuurd onderwijs beschreven. Daarna werden die elementen van het onderwijs aan de orde gesteld die in dit proefschrift van bijzonder belang zijn: het functioneren van onderwijsgroepen en de rol van de tutor daarbij. Deze bijzondere aandacht voor de tutorrol in dit hoofdstuk kwam voort uit het doel van het in dit proefschrift beschreven onderzoek: het opsporen van positieve en negatieve effecten van de inzet van studenten als tutor. Alvorens resultaten van dat onderzoek te presenteren, zal in het volgende hoofdstuk eerst een overzicht worden gegeven van de literatuur op dit terrein. 


\section{Studenten als docenten in het onderwijs}

\section{Inleiding}

In dit hoofdstuk wordt een overzicht gegeven van het onderzoek naar, en mogelijke verklaringen voor, de effectiviteit van onderwijs waarbij studenten geplaatst worden in de rol van docent. Eerst worden verschillende termen en definities besproken die in de literatuur voorkomen en een aantal overwegingen behandeld op grond waarvan onderwijsinstellingen kunnen besluiten tot het inschakelen van studenten in de rol van docent. In de daarop volgende paragraaf worden verschillende vormen van studentgeleid onderwijs beschreven. Het onderzoek naar de effecten van studentgeleid onderwijs krijgt daarna aandacht. Tenslotte worden enige veronderstellingen voor de mogelijke effectiviteit van studentgeleid onderwijs aan de orde gesteld. Het hoofdstuk wordt besloten met een bespreking van de verdere inhoud van dit proefschrift.

\section{Overwegingen om studenten als docent in het onderwijs in te schakelen}

In de onderwijskundige literatuur is het inschakelen van studenten in het onderwijs bekend geworden onder de verzamelnamen "peer teaching" en "peer tutoring". Van peer teaching is sprake wanneer studenten van ongeveer dezelfde leeftijd en relatief gelijk opleidingsniveau elkaar onderwijzen (Goldschmid \& Goldschmid, 1976). Onder de term peer tutoring vallen onderwijs- 
situaties waarbij studenten van oudere leeftijd en met een hoger opleidingsniveau jongerejaars onderwijzen (Wagner, 1982). ${ }^{1}$

In het Nederlandse taalgebied wordt de term "studentgeleid onderwijs" het meest gehanteerd. Ten Cate, Tromp en Cornwall (1984) definiëren studentgeleid onderwijs, in navolging van Cornwall (1980), als "het geheel van onderwijsactiviteiten waarmee studenten elkaar helpen te leren door bewust daarvoor bedoelde interactie" (p. 19). De definitie omvat, volgens eerstgenoemde auteurs, enerzijds vormen van onderwijs die expliciet deel uitmaken van het reguliere curriculum, maar anderzijds worden vormen van onderwijs die door de studenten buiten het curriculum worden geïnitieerd, niet uitgesloten. Evenmin worden vormen uitgesloten waarbij de docent zijdelings betrokken is. In deze studie zal verder vooral de meer globale term studentgeleid onderwijs gebruikt worden. Peer teaching en peer tutoring zullen slechts gehanteerd worden waar een expliciet onderscheid gemaakt wordt tussen onderwijssituaties waar studenten respectievelijk begeleid worden door studenten van eenzelfde dan wel van een hoger opleidingsniveau.

Studenten betrekken bij het onderwijs is niet van recente datum. Reeds in de oudheid en middeleeuwen werden studenten ingezet om medestudenten te helpen bij hun studie (Wagner, 1982). Voorzover we weten, wordt sinds het einde van de achttiende eeuw de term peer teaching gebruikt, toen de hoofdonderwijzers Bell en Lancaster leerlingen voor het eerst systematisch betrokken bij het onderwijs aan medeleerlingen (Topping, 1988; Wagner, 1982). In de negentiende eeuw bloedden deze activiteiten grotendeels dood, totdat tijdens de jaren zestig van deze eeuw de belangstelling ervoor weer sterk opbloeide. Met name in de Verenigde Staten, waar leerlingen op openbare scholen relatief slechte leerprestaties behaalden in vergelijking met hun leeftijdsgenoten op privéscholen, werd in het primair en secundair onderwijs geëxperimenteerd met verschillende vormen van onderwijs waarbij de oudere leerlingen jongere onderwezen (Allen, 1976; Melarango, 1976; Paolitto, 1976). In een later stadium werden ook vormen geïntroduceerd waarbij leerlingen van eenzelfde leeftijd en opleidingsniveau elkaar onderwezen. Deze laatste benadering wordt in de literatuur ook wel aangetroffen onder de termen "cooperative" en "collaborative learning" (Cohen, 1984; Damon \& Phelps, 1989; Sharan, 1980, 1984; Slavin 1980).

\footnotetext{
${ }^{1}$ Naast deze termen worden ook andere benamingen gebruikt voor onderwijsleersituaties waarbij studenten medestudenten onderwijzen, zoals "peer assisted learning" (Alexander, Gur, Gur \& Patterson, 1984; Comwall, 1980), "reciprocal peer tutoring" (Allen \& Boraks. 1978). "peer mediated instruction" (Rosenbaum, 1983), "peer group learning" (Collier. 1980) en "collaborative peer learning" (Magin. 1982). Deze termen worden echter minder frequent gebruikt en betekenen in principe hetzelfde als peer teaching of peer tutoring. We zullen ze daarom in dit proefschrift verder niet gebruiken.
} 
In het hoger onderwijs is pas sinds de jaren zeventig belangstelling ontstaan voor onderwijsvormen waarbij studenten onderwijstaken van docenten overnemen. We komen op deze ontwikkeling, en op de verschillende wijzen waarop studentgeleid onderwijs daarin gestalte heeft gekregen, nog nader terug.

Inschakeling van studenten in het verzorgen van onderwijs voor medestudenten berust op verschillende overwegingen. Onderwijsinstellingen kunnen studenten inschakelen op grond van overwegingen van pedagogische aard. Doordat studenten meer betrokken worden bij, en meer verantwoordelijkheid dragen voor elkaars leerproces, worden ze uitgedaagd tot een meer actieve opstelling. Deze actieve betrokkenheid zou kunnen resulteren in een sterkere motivatie tot leren (Collier, 1983). Daarnaast zouden door een grotere interactie tussen studenten onderling hun communicatieve vaardigheden verbeteren. Op het vlak van kennisverwerving verwacht men dat een meer actief met de leerstof bezig zijn een positief effect zal hebben op de verwerking van die stof. De studenten krijgen immers vaker de gelegenheid de leerstof te bewerken, zowel tijdens de zelfstudie als tijdens het feitelijke onderwijs. Ze worden door hun medestudenten frequenter getoetst en krijgen sneller en directer feedback op het geleerde. Bovendien is de verwachting dat studenten in een leeromgeving met "peers" sneller vragen durven te stellen of aan te geven dat ze iets niet begrijpen (Fineman, 1981; Goldschmid \& Goldschmid, 1976; Nedermeyer, 1982). De studiemotivatie en betrokkenheid bij de leerstof zou daarnaast toenemen door gedeelde verantwoordelijkheid en de sterke invloed die studenten uitoefenen op elkaars studiegedrag en studieprestaties. Tevens is gebleken dat studenten die zélf onderwijs verzorgen daarvan profiteren wat betreft hun studieprestaties, niet alleen doordat ze de studiestof kunnen herhalen maar vooral door de sterke leerstofverwerkende functie die van doceren uitgaat (Annis, 1983; Bargh \& Schul, 1980; Cohen, Kulik \& Kulik, 1982).

Ook economische motieven worden genoemd voor het invoeren van studentgeleid onderwijs. In het hoger onderwijs bestaat de tendens het onderwijs te extensiveren, dit wil zeggen het vergroten van het aantal studenten per docent. Dit leidt tot een ontwikkeling waarbij docenten steeds minder directe invloed kunnen uitoefenen op de activiteiten van studenten. Het inschakelen van ouderejaarsstudenten kan ertoe leiden dat het onderwijs toch een kleinschalig karakter behoudt. Andere economische motieven zijn dat studentassistenten relatief goedkope docenten zijn en dat de staf-student ratio verhoogd wordt wanneer studenten de mogelijkheid wordt geboden onderwijstaken van stafleden over te nemen (Dixon, 1983).

Tenslotte zijn er overwegingen van sociaal-psychologische aard. De massale instroom van studenten in het hoger onderwijs heeft ertoe geleid dat de afstand tussen docenten en studenten sterk is toegenomen. Tevens is, door de sterke toename van de studentenaantallen, het contact tussen studenten 
onderling bemocilijkt. Wanneer studenten worden betrokken bij het verzorgen van onderwijs aan elkaar bestaat de mogelijkheid dat ze sneller contact met elkaar maken waardoor de massaliteit van het onderwijs gemakkelijker doorbroken wordt (Trakman, 1979). Uit onderzoek blijkt dat studiegenoten bovendien veel invloed uitoefenen op de wijze waarop men studeert, op de studieprestaties en op het al dan niet volhouden van de studie. De inspanningen die men zich getroost ten aanzien van zijn studie worden in hoge mate mede bepaald door de referentiegroep waartoe men zich zelf rekent (Hallinan, 1982; Newcomb, 1974).

\section{Vormen van studentgeleid onderwijs in het hoger onderwijs}

Cornwall (1980) en Ten Cate (1986) onderscheiden vormen van studentgeleid onderwijs langs drie dimensies. Ten eerste zijn er leersituaties waarin twee studenten met elkaar samenwerken en situaties waarbij méér dan twee studenten elkaar onderwijzen. Ten tweede kunnen leersituaties onderscheiden worden waarin studenten direct interacteren met medestudenten van gelijk opleidingsniveau, of worden onderwezen door medestudenten met een hoger opleidingsniveau. Ten slotte kan nog een onderscheid gemaakt worden naar de mate van structurering van de leersituatie. Soms moet de onderwijzende student via specifieke, door de docent bepaalde, procedures handelen; soms worden onderwijsdoeleinden, onderwerp en wijze van werken in hoge mate door de studenten zelf bepaald.

Enkele bekende vormen van studentgeleid onderwijs in het hoger onderwijs waarbij studenten in tweetallen bepaalde leerstof bestuderen zijn het "personalized system of instruction" (Keller, 1968) en de "learning cell" (Goldschmid, 1971; Goldschmid \& Shore; 1974).

Een bekende vorm van peer tutoring in het hoger onderwijs is onderwijs door middel van werkgroepen verzorgd door student-assistenten (Kitchener \& Hurst, 1974; Maas \& Pressler, 1973). Kenmerkend voor deze vorm van peer tutoring is dat de onderwijstaken van de student-docent niet afwijken van de wijze waarop stafleden hun onderwijs uitvoeren. Dat wil zeggen dat de studenten die aan deze onderwijsleersituaties worden blootgesteld vooral consumenten zijn van datgene wat de student-docent offreert.

Naast deze, reeds lang bestaande, vorm van studentgeleid groepsonderwijs waarbij in het algemeen tamelijk grote groepen van studenten (20 tot 40 personen) betrokken zijn, hebben sinds de laatste twintig jaar nieuwe kleinschaliger methoden van groepsonderwijs in het hoger onderwijs hun intrede gedaan (Abercrombie, 1974; Gall \& Gall, 1976). Daarbij krijgen studenten over het algemeen een grotere zelfstandigheid en verantwoordelijkheid bij de uitvoering van het onderwijs toebedeeld. Zo wordt veelvuldig gewerkt met 
kleine groepjes studenten (4 tot 12 personen) die met elkitar. onder begeleiding van een docent discussiëren (Hill, 1969). ${ }^{2}$

Kenmerkend voor dergelijke "student learning groups" en is dat de studenten gedurende een aantal minuten aan een bepaalde taak werken (bijvoorbeeld het vergelijken van twee röntgenfoto's), waarna in een grotere groep, vaak onder leiding van een docent, verder gediscussieerd wordt over ieders bevindingen en aanverwante onderwerpen. In de "syndicates" (Collier, 1966) wordt een klas van ongeveer 30 studenten opgesplitst in kleinere groepjes van 4 à 8 studenten, die een serie taken op coöperatieve basis moeten doorwerken. De docent is daarbij niet aanwezig. Na enige tijd komen de groepjes in een plenaire sessie bijeen alwaar, onder leiding van de docent, de resultaten van de groepsdiscussies besproken worden en de grote gemeenschappelijke lijnen en structuren in de leerstof vastgesteld worden. Kern van deze werkvorm is echter volgens de "bedenker" van deze methode het intensieve debat in de syndicates (Collier, 1980, 1983, 1985).

In welke mate speelt studentgeleid onderwijs een rol in de probleemgestuurde onderwijssetting? Zoals reeds beschreven, vindt het contactonderwijs tussen studenten en docent in probleemgestuurd onderwijs plaats in de onderwijsgroep. De onderwijsgroep bestaat uit ongeveer tien studenten die gezamenlijk de taken bespreken die hen worden voorgelegd. De studenten zijn in belangrijke mate zelf verantwoordelijk voor het verwerken van het studiemateriaal. Het is primair de taak van de studenten om elkaar te informeren en vragen te stellen over de onderwerpen die aan de orde zijn in het kader van het thema dat bestudeerd wordt. De leden van een onderwijsgroep nemen op basis van gelijkwaardigheid deel aan de discussies. De discussies worden gestructureerd doordat tijdens de analyse van de aangeboden taken en de rapportage van de bestudeerde leerstof volgens bepaalde procedures gewerkt wordt (Moust, Bouhuijs \& Schmidt, 1989). Gezien het feit dat in een onderwijsgroep studenten taken van de docent overnemen, kan dit als een vorm van peer teaching worden beschouwd. Studenten worden bij hun leeractiviteiten in een onderwijsgroep echter begeleid door een staflid. Hoewel deze docent geen leidende maar een ondersteunende rol heeft, hoeft zijn invloed op het leren van studenten niet gering te zijn. Zijn positie is gelijk noch gelijkwaardig aan die van zijn studenten. Zo is bijvoorbeeld zijn kennis over de onderwerpen die ter sprake komen in het algemeen uitgebreider en diepgaander. Tevens heeft hij een nauwomschreven verantwoordelijkheid voor het leer- en samen-

${ }^{2}$ Groepsonderwijs waarbij (tijdelijk) geen docent of student-assistent bij de discussie tussen studenten aanwezig is, zijn "self-directed student groups" (Beach, 1974), "student centered instruction" (McKeachie, 1954), "associative discussion groups" (Rudduck, 1978) en "syndicates" (Collier, 1966, 1983). 
werkingsproces van de studenten. Hoewel hij hierin slechts adviserend kan optreden, zullen de studenten in de praktijk toch vaak de aanbevelingen van de docent-tutor opvolgen. Wanneer echter studenten in onderwijsgroepen begeleid worden door een student-assistent, in dit geval een medestudent uit cen hoger studiejaar, is er sprake van peer tutoring.

De vraag rijst uiteraard in hoeverre studenten in staat zijn een zinvolle bijdrage aan elkaars leren te leveren. Ten einde een voorlopig antwoord op die vraag te formuleren, wordt in de volgende paragraaf onderzoek gepresenteerd waarbij cognitieve en niet-cognitieve effecten van studentgeleid onderwijs onderzocht zijn. Vervolgens worden enige theoretische noties besproken die een bijdrage kunnen leveren aan het begrijpen van die effecten.

\section{Effecten van studentgeleid onderwijs}

Er is veel onderzoek gedaan naar effecten van studentgeleid onderwijs. Het meeste onderzoek heeft plaatsgevonden binnen het (Amerikaanse) basis- en voortgezet onderwijs. Met betrekking tot peer tutoring (ouderejaarsleerlingen die jongerejaars onderwijzen) worden vaak positieve effecten gevonden op de leerprestaties als ook op sociaal-psychologische aspecten (Allen, 1976; Cohen et al., 1982; Devin-Sheehan, Feldman \& Allen, 1976; Topping, 1988). De resultaten van onderzoek naar peer teaching (leerlingen van hetzelfde niveau die elkaar onderwijzen), spreken elkaar daarentegen nogal tegen (Johnson, Maruyama, Johnson, Nelson \& Skon, 1981; Sharan, 1980; Slavin, 1980; Webb, 1982).

We laten hier het onderzoek naar studentgeleide methoden in het primair en secundair onderwijs buiten beschouwing en concentreren ons op onderzoek uitgevoerd in het hoger onderwijs. We doen dat vanuit de veronderstelling dat resultaten van onderzoek bij kinderen zich waarschijnlijk slecht laten generaliseren naar volwassenenonderwijs. In het hiemavolgende overzicht zal in lijn met het voorafgaande een onderscheid gemaakt worden tussen twee typen studies: onderzoek naar peer teaching en onderzoek naar peer tutoring.

\section{Effecten van peer teaching}

Cognitieve effecten van peer teaching zijn niet eenduidig vastgesteld: in de literatuur treffen we elkaar tegensprekende onderzoeksresultaten aan. We zullen achtereenvolgens onderzoek bespreken waarin geen verschillen gevonden worden tussen groepen met en groepen zonder docent, onderzoek waarbij de studenten zonder begeleidende docent betere leerprestaties leveren en tenslotte onderzoek waarbij studenten die onderwijs volgen in docentloze groepen tot slechtere leerprestaties komen. 
Hovey, Gruber, en Terrell (1963) vergeleken twee groepen eerstejaars psychologiestudenten die een cursus onderwijspsychologie onder twee verschillende condities volgden. Eén groep kreeg de cursus aan de hand van drie colleges per week. De andere groep had één college en twee bijeenkomsten per week, waarin kleine groepjes van zes personen, aan de hand van opdrachten (leesteksten, discussie-onderwerpen en een aantal vragen opgesteld door de cursusleiding) discussieerden over de leerstof. De groepen waren aselect samengesteld. Voordat het experiment begon kregen de studenten die zouden werken in de groepen een korte training in discussietechnieken. Aan het einde van de cursus kregen alle studenten een afsluitend tentamen voorgelegd, gedeeltelijk bestaande uit meerkeuze en juist-onjuist vragen en uit open vragen waarop korte antwoorden moesten worden gegeven. Het cijfer van de studenten voor de gehele cursus werd bepaald uit de resultaten op dit afsluitend tentamen en aan de hand van de resultaten die zij behaalden op tussentijdse toetsen. Hovey en zijn collega's vonden geen significante verschillen tussen beide groepen, hoewel de "zelfgestuurde" groepen het lichtelijk beter deden. De onderzoekers gingen tien maanden later nogmaals na wat de studenten zich nog herinnerden van de leerstof van deze cursus en de mate waarin zij nog activiteiten hadden ontwikkeld als gevolg van deze cursus. Deze werkzaamheden noemden de onderzoekers "lasting curiosity". In diezelfde periode werd ook een nameting verricht die bestond uit een soortgelijke toets als de toets afgenomen direct na afloop van het onderwijs. Ook nu scoorden de zelfgestuurde groepen lichtelijk beter, maar wederom waren er geen significante verschillen tussen deze groep en de groep studenten die alleen de colleges had gevolgd. Op een vragenlijst naar nieuwsgierigheid naar onderwerpen die tijdens de cursus aan de orde waren geweest, scoorden de zelfgestuurde groepen echter significant beter dan de studenten die de hoorcolleges gevolgd hadden. Ze stelden meer vragen naar aanleiding van voorgelegde problemen, hun vragen waren diverser van aard en ze hadden meer boeken en wetenschappelijke tijdschriftartikelen gelezen over de onderwerpen die in de cursus aan de orde waren geweest. De studenten die de colleges gevolgd hadden, scoorden echter significant hoger in het gebruik van hun kennis. Zo bleken die studenten onder andere vaker kinderen en onderwijzers in klassesituaties te zijn gaan observeren, vergaderingen van schoolbesturen te volgen en het geleerde in praktijk te brengen bij remedial teaching activiteiten. Hovey et al. herhaalden hun onderzoek in verkorte vorm in het volgende studiejaar, waarbij ze dezelfde resultaten vonden.

Beach (1974) vergeleek tweedejaars psychologiestudenten, die gedurende een semester een cursus sociale psychologie volgden. Een deel van de studenten kreeg het onderwijs in kleine groepjes. Die groepjes kwamen minimaal eenmaal per week samen om de leerstof te bespreken en hadden eens per veertien dagen, op vrijwillige basis, contact met de docent. De andere studenten volgden drie maal per week een hoorcollege-met-discussie-na. Beach rap- 
porteerde soortgelijke resultaten als Hovey et al. (1963) wat betreft de korte termijn leerprestaties. Er waren geen significante verschillen in de leerprestaties tussen beide groepen. Beach meldde dat de kleine groepen wel iets beter scoorden op de toets dan de groep studenten die colleges kreeg. In zijn rapportage blijft de auteur echter tamelijk vaag over de concrete data betreffende de leerprestaties. Hij verschaft alleen gegevens met betrekking tot wat hij noemt "other desirable outcomes of the course experience" (p. 190). Uit deze gegevens blijkt dat de studenten uit de kleine groepen zich breder en diepgaander oriënteren op het cursusonderwerp. Ook deze bevindingen komen overeen met de uitkomsten van Hovey et al. (1963).

Ten Cate (1986) ging na in hoeverre er een verschil in leereffect optreedt wanneer studenten onderwijs in kleine groepen volgen dat verzorgd wordt door een medestudent, in vergelijking met onderwijs dat verzorgd wordt door een docent. Het beschreven onderzoek was deels exploratief, deels toetsend van aard. Het onderzoek werd uitgevoerd bij eerstejaars studenten geneeskunde in een vijfweeks onderwijsblok, getiteld "Methoden en technieken van medisch wetenschappelijk onderzoek". Het onderzoek had betrekking op de tweede en derde week van dit blok waarin respectievelijk aandacht werd besteed aan medische statistiek en medische informatica. Het onderwijs bestond uit zes werkgroepbijeenkomsten van telkens drie uur. De eerste vier bijeenkomsten hadden betrekking op methodologie en statistiek ten behoeve van medisch wetenschappelijk onderzoek, in de vijfde en zesde bijeenkomst werd een inleiding in de medische informatica behandeld. Het experiment werd uitgevoerd bij een grote groep studenten $(n=260)$, die onderverdeeld was in drie groepen van ongeveer gelijke omvang en waarvan de studenten op dezelfde wijze de experimentele en de controlebehandeling ontvingen. De aanwezigheid van de studenten op de bijeenkomsten was verplicht en werd streng gecontroleerd. Als sanctie op onvoldoende deelname moesten de studenten die minder dan vijf bijeenkomsten bijwoonden een of meer vervangende opdrachten maken of werden zij van deelname aan de bloktoets uitgesloten. Het onderwijs werd gegeven aan 24 groepen, elk bestaande uit tien à twaalf studenten. Alle studenten werden aselect ingedeeld in één van de 24 groepen. Vervolgens werden de groepen aselect toegewezen aan de experimentele conditie (studentgeleide bijeenkomsten) of de controleconditie (docentgeleide bijeenkomsten). Van de zes bijeenkomsten waren er voor elke groep twee docentgeleid en werden de overige vier bijeenkomsten geleid door daartoe aselect aangewezen studenten uit de groep zelf, de zogenoemde peer teachers. Deze peer teachers hadden in de studentgeleide bijeenkomsten steeds in tweetallen de leiding. In de docentgeleide conditie werd het onderwijs verzorgd door telkens een docent van de vakgroep Medische Fysica. Aan het onderzoek namen zes stafleden deel. De peer teachers werden geacht gezamenlijk (als duo) de stof voor de bijeenkomst extra goed voor te bereiden, waarbij zij kort voor hun sessie met hun collegae peer teachers bijeen kwa- 
men om onder leiding van een docent nog eventuele onopgeloste problemen te bespreken. De cursus die aan de studenten werd gegeven was strak georganiseerd. Aan het begin van de cursus ontvingen de studenten een syllabus die gedetailleerde informatie bevatte over werkwijze, rooster en leerstof. De leerprestaties van de studenten in de beide condities werden op vier momenten gemeten: direct na de tweede, vierde en zesde bijeenkomst en aan het einde van het blok, veertien dagen na de zesde bijeenkomst. De eerste drie toetsen, formatieve oefentoetsen, bestonden elk uit 40 vragen van het waar/onwaar type. De vierde toets, de summatieve bloktoets, bestond uit tien in gewicht gelijk gewaardeerde onderdelen, waarvan vier onderdelen betrekking hadden op de twee weken onderwijs waarin het onderhavige experiment plaatsvond. Drie van deze vier onderdelen hadden de vorm van een samengestelde essay-vraag, het vierde onderdeel bestond uit 24 vragen van het waar/onwaar type. Ten Cate vond geen significante verschillen in leereffect tussen de groepen die hetzij student-, hetzij docentgeleid onderwijs volgden. Dat gold zowel voor de toetsen die direct na afloop van de bijeenkomsten werden afgenomen (de oefentoetsen) als op de relevante gedeelten van de bloktoets die twee weken na de laatste werkgroepbijeenkomst werd afgenomen.

Met behulp van een vragenlijst onderzocht Ten Cate enkele malen het oordeel van de studenten over de docent- en studentgeleide bijeenkomsten. De studentoordelen bleken niet sterk van elkaar te verschillen. Het duidelijkste verschil betreft de gelegenheid tot deelname aan de discussie. Deze was steeds groter in de studentgeleide conditie. Ten Cate constateert echter ook dat er een interactie lijkt te bestaan tussen het onderwerp dat op de bijeenkomsten aan de orde komt en de mate waarin studenten er iets van geleerd hebben. "In het algemeen meenden de studenten dat zij van het docentgeleide onderwijs iets meer leren dan van het studentgeleide onderwijs. Bij het studentgeleide onderwijs meenden zij iets meer actief betrokken te zijn geweest" (p. 181).

White (1945) vergeleek de leerprestaties van studenten tijdens een laboratoriumcursus werktuigbouwkunde. Vergeleken werden de toetsresultaten van groepjes studenten zonder docent (drie à vier personen) met een groep studenten die onderwijs kreeg van een docent met behulp van hoorcolleges en demonstraties. White onderzocht zowel verschillen in feitenkennis als verschillen in het vermogen van de studenten om algemene wetenschappelijke principes te begrijpen en toe te passen. De metingen vonden plaats direct na afloop van de onderwijsperiode, die één semester duurde, en zes maanden na de eerste meting. White vond dat de studenten die werkten in de kleine docentloze groepen significant betere leerprestaties haalden op de feitenkennistoets direct na afloop van de onderwijsperiode. Wat betreft eventuele verschillen in het vermogen om principes te begrijpen en toe te passen vond White geen significante verschillen in leerprestaties. De studenten in de zelfstandig werkende groepjes scoorden echter iets hoger. De tweede meting, 
zes maanden na de eerste meting, leverde geen verschillen meer op tussen beide condities op zowel het niveau van feitenkennis als op het niveau van het begrijpen en toepassen van algemene wetenschappelijke principes.

Blunt en Blizzard (1973) vergeleken het anatomie-onderwijs van twee jaargroepen met elkaar. De jaargroep 1971 ontving dit onderwerp via hoorcolleges, de jaargroep $1972 \mathrm{kreeg}$ het anatomie-onderwijs aangeboden door middel van kleine discussiegroepjes bestaande uit vijf studenten elk. Beide jaargroepen verschilden niet op hun middelbare schoolcijfers, wat volgens de auteurs duidt op een redelijk hoge mate van vergelijkbaarheid van die jaargroepen. De auteurs melden significant betere toetsprestaties van de studenten die anatomie-onderwijs volgden door middel van de discussiegroepjes. De toetsen bestonden uit meerkeuzevragen. De studenten die deelnamen aan het onderwijs via discussiegroepen behaalden echter ook voor een ander vak hogere cijfers dan de studenten uit het voorgaande studiejaar. De jaargroep 1972 zou als geheel dus beter geweest kunnen zijn dan de studenten uit het voorafgaande jaar. Uit het onderzoek wordt daamaast niet duidelijk of de anatomie-examens in beide studiejaren een gelijke moeilijkheidsgraad hadden.

Clement (1971) vergeleek de leerprestaties van studenten werkzaam in kleine discussiegroepjes zonder docent met de leerprestaties van studenten die begeleid werden door een docent. Tijdens de vierde cursusweek kregen alle studenten, na aanvang van de bijeenkomst, een essayvraag voorgelegd. Nadat de vraag individueel beantwoord was, konden twaalf studenten verdeeld over drie at random samengestelde discussiegroepjes, hun antwoord op deze vraag bediscussiëren. De andere studenten $(\mathbf{n}=11)$ bleven bij elkaar om onder leiding van de docent, hun antwoord door te praten. Na 30 minuten kregen alle studenten dezelfde vraag weer voorgelegd om deze schriftelijk te beantwoorden. De cursus werd daarna weer op de gewone wijze voortgezet. Zes weken later kregen alle studenten weer dezelfde vraag van de vierde cursusweek te beantwoorden. Alle antwoorden (van de in totaal drie meetrondes) werden door de onderzoeker gecodeerd en beoordeeld door drie onafhankelijke docenten. Clement vond dat de prestaties van de studenten in de groepjes zonder docent niet verschilden van de prestaties van de studenten begeleid door de docent op de toetsing die voorafgaande aan en meteen volgend op de discussieperiode van dertig minuten plaatsvond. De leerresultaten verschilden echter wel op de test die zes weken later plaatsvond. De studenten die zonder begeleiding van een docent over de antwoorden op de vraag discussieerden, leverden significant betere prestaties. De onderzoeker schrijft dit effect toe aan de grotere actieve inbreng in de discussie bij de zelfstandig werkende groepjes.

In verschillende literatuuroverzichten wijst Collier $(1980,1983,1985)$ op onderzoekingen waarin gemeld wordt dat studentgeleid onderwijs vooral leidt tot betere resultaten op het vlak van hogere cognitieve vaardigheden, zoals het oplossen van problemen of het toepassen van kennis in nieuwe domeinen. 
Zo zouden studenten, onderwezen via "syndicates". of analoge vormen van studentgeleid onderwijs, beter in staat zijn informatie te interpreteren en te extrapoleren (Glew, 1983; Rodger, 1983), geleerde principes beter kunnen toepassen op nieuwe situaties (Clarke, 1983; Clement, 1971; Edwards, 1983), beter problemen kunnen oplossen (Clarke, 1983; Edwards, 1983; Magin, 1983) en een meer kritische houding ontwikkelen ten aanzien van het bestudeerde materiaal (Beach, 1974; Chambers, 1983). Ook de studies van White (1945) en Blunt en Blizzard (1973) worden door Collier (1980, 1983) geciteerd als bronnen waarin aangetoond zou worden dat onderwijs in kleine groepen leidt tot betere prestaties in het hogere cognitieve domein. Opvallend is dat Collier bij de bespreking van deze laatste twee onderzoeken steeds uit "de tweede hand" citeert. Directe bestudering van de genoemde bronnen laat echter zien dat Colliers' interpretatie van de onderzoeksresultaten discutabel is. Blunt en Blizzard (1978) vergeleken, zoals hierboven vermeld, waarschijnlijk twee verschillend samengestelde groepen en verstrekken weinig informatie over de toetsprocedures. Het onderzoek van White (1945) is, zoals Ten Cate (1986) al meldt, "zeer incompleet beschreven en biedt weinig inzicht in de gehanteerde meetinstrumenten" (p. 61). White (1945) noemt de "ability to understand and apply generalizations from science" niet significant verschillend en spreekt slechts van trends ten voordele van de studentgeleide groep. Ook veel van de andere onderzoekers die Collier in zijn publicaties van 1983 en 1985 citeert, rapporteren hun onderzoeksopzet en bevindingen weinig zorgvuldig. In zijn eigen studies maakt Collier $(1966,1969,1983)$ veelvuldig gebruik van protocollen van slechts enkele studenten op basis waarvan hij eerder genoemde generalisaties met betrekking tot het verwerven van hogere cognitieve vaardigheden onderbouwt. Het lijkt daarom, wat betreft het effect van docentloze groepen op het verwerven van hogere cognitieve vaardigheden, vooralsnog veiliger aan te sluiten bij Colliers' constatering (1980) dat de onderzoeksresultaten met betrekking tot hogere cognitieve vaardigheden "have been scattered and often subjective" en het vervolg daarop: "but nevertheless impressive" (p. 56) niet klakkeloos te accepteren. De vraag of peer teaching leidt tot een betere verwerving van hogere cognitieve vaardigheden dan onderwijs verzorgd door docenten kan dus op grond van empirisch onderzoek noch bevestigend noch ontkennend beantwoord worden.

In de literatuur werd één studie gevonden waarin docentloze groepen slechter presteerden dan studenten begeleid door docenten. Beach (1983) vergeleek 54 tweedejaars studenten, die gedurende een semester een cursus sociale psychologie volgden (de experimentele groep) met 41 studenten die direct voorafgaande of volgend op het experiment dezelfde cursus volgden (de controlegroep). De experimentele groep werd at random verdeeld over negen groepjes van elk zes personen. Deze studenten kregen voorafgaande aan het experiment een korte cursus werken in kleine groepen. Deze "selfdirected study groups" kwamen wekelijks in hun eigen tijd bijeen en organi- 
seerden op hun eigen wijze hun werkzaamheden om de leerstof die via een syliabus aangereikt werd te bespreken. Iedere veertien dagen was er een plenaire bijeenkomst met de docent, die wekelijks ook nog gelegenheid bood tot individuele consultatie. Vergelijking van de leerprestaties van de studenten in de controlegroep, over wier activiteiten door Beach met geen woord gerept wordt, laat zien dat de laatsten het significant beter doen dan de resultaten van de studenten in de experimentele groep.

Met betrekking tot effecten van peer teaching op andere dan cognitieve metingen ziet het beeld er positiever uit. Wordt studentgeleid onderwijs (i.c. syndicates) vergeleken met de gebruikelijke onderwijsvormen in het hoger onderwijs dan is de hogere motivatie van de studenten en hun grotere betrokkenheid bij academisch onderwijs in eerstgenoemde onderwijs opvallend beter. Studenten volgen de bijeenkomsten beter (Clarke, 1983; Field, 1973), spenderen meer tijd en energie aan hun studie (Beach, 1974; Glew, 1983; Rudduck, 1978), zijn meer betrokken bij hun studie (Collier, 1966) en bij hun medestudenten in de discussiegroep (Rudduck, 1978).

Samenvattend kan gesteld worden dat de onderzoeken naar de cognitieve effecten van peer teaching in het hoger onderwijs geen eenduidige resultaten opleveren. Tabel 2.1 geeft een overzicht van dat onderzoek. In de meeste onderzoeken worden geen verschillen in leerprestaties geconstateerd, in sommige onderzoekingen scoren de studenten in de docentloze groepen hoger; in een enkel geval lager dan de studenten in de docentbegeleide groepen. Onderzoek naar niet-cognitieve effecten toont op tamelijk eenduidige wijze aan dat studenten wel positiever oordelen over onderwijs in kleine groepen dat docentonafhankelijk plaatsvindt. Studenten rapporteren dat ze sterker gemotiveerd worden tot leren en dat ze zich meer betrokken voelen bij hun studie dan bij docentgeleide onderwijsvormen. Ze tonen zich sterker bereid meer tijd en energie in hun studie te steken, zoeken actiever naar informatie en oriënteren zich breder op het terrein van hun studie.

\section{Effecten van peer tutoring}

In de vorige paragraaf werden docentloze groepen vergeleken met groepen waarin studenten onderwezen werden door een docent. In deze paragraaf wordt onderzoek aan de orde gesteld waarin vergelijkingen gemaakt werden tussen groepen studenten begeleid door een ouderejaarsstudent met groepen waarin studenten begeleid worden door een docent. Vergelijkend onderzoek van dit type blijkt zeer schaars. In feite konden slechts twee studies gevonden worden.

Bloxom, Caul, Fristoe en Thompson (1975) onderzochten de leerprestaties van psychologie studenten in een eerstejaars blok. Dit blok bestond uit vijf subblokken. In twee blokken ontvingen de studenten drie uur college per week van verschillende docenten die hetzelfde boek gebruikten. In de andere 
Tabel 2.1

Overzicht van onderzoek naar studentgeleid onderwijs

Peer teaching

$\begin{array}{ll}\text { onderzoeker(s) } & \begin{array}{l}\text { samenstelling wijze van toetsing resultaten } \\ \text { groepen }\end{array}\end{array}$

White (1945)

17 docentloze

groepen ( $N=4$ )

vs. 1 collegegroep

$(\mathrm{N}=75)$

Hovey, Gruber \& 9 docentloze groepen

Terrell (1963)

$$
(\mathrm{N}=6)
$$

vs. 1 collegegroep

( $\mathrm{N}=62$ )

Clement (1971)

3 docentloze groepen

$(\mathrm{N}=4)$

vs. 1 docentgeleide

groep $(\mathrm{N}=11)$

Blunt \& Blizzard

(1973)

40 docentloze

groepen $(\mathrm{N}=5)$

vs. 1 collegegroep

$(\mathrm{N}=219)$

Beach (1974)

Beach (1983)

onbekend aantal docent loze groepen ( $\mathrm{N}=5$ ) vs.

onbekend aantal stu-

denten in collegegroep

meerkeuze

vragen

meerkeuze vragen

\& juist-onjuist

vragen \& korte

antwoord vragen

essayvragen

2 afhankelijke metingen; studentgeleide groep

beter

10 onafhankelijke metingen; studentgeleide groep

beter

geen verschillen

niet vermeld

9 docentloze groepen

$(\mathrm{N}=6)$ vs, onbekend aan-

tal studenten in 1 col-

legegroep

Ten Cate (1986)

22 docentloze groepen

$(\mathrm{N}=11)$ vs. 13 docent-

geleide groepen $(\mathrm{N}=11)$ niet vermeld

docentgeleide groep

beter

waar-onwaar vragen geen verschillen \& open vragen studentgeleide

groepen beter; post-hoc meting (na

6 mnd.) geen

verschillen

geen verschillen

\author{
me-
}

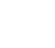


veer tien personen werden geleid door een ouderejaars student. In deze drie subblokken werd hetzelfde handboek gebruikt als in de eerste twee subblokken. De studenten die de discussiegroepen begeleidden, hadden voor het experiment twee tweedejaars blokken doorlopen waarin aan de eerstejaarsstof nogmaals aandacht werd besteed. Toegelaten tot de begeleiding van de discussiegroepen werden alle studenten die redelijke prestaties gehaald hadden op een afsluitend examen van deze twee blokken. Vergeleken werden de leerprestaties van de eerstejaars studenten over de verschillende subblokken met behulp van een toets met meerkeuzevragen, opgesteld door een onafhankelijke docent. De onderzoekers concludeerden dat hoewel er in de verschillende subblokken vaak significante verschillen in leerprestaties gevonden werden, die verschillen niet consistent ten voor- of nadele van de discussiegroepen waren. Helaas vermeldden de onderzoekers in hun rapportage geen feitelijke data.

Carsrud (1979) vergeleek de leerprestaties van 531 eerstejaars psychologiestudenten met behulp van een toets bestaande uit meerkeuze vragen. Voorafgaande aan het onderzoek werd de voorkennis van alle studenten getest door middel van een vragenlijst bestaande uit 25 items. Er waren geen significante verschillen tussen de studenten. Vervolgens werden de studenten aselect ingedeeld in één van drie condities: één groep volgde hoorcolleges ( $\mathbf{n}=$ $326)$, een andere groep studenten $(n=112)$ werd opgedeeld in niet-begeleide groepen die van de docent wekelijks een bepaalde hoeveelheid leerstof ontvingen en een derde groep studenten werd opgedeeld in kleine groepjes van ongeveer zes personen elk die wekelijks een à twee uur samenkwamen om, onder leiding van een ouderejaarsstudent, de leerstof te bediscussiëren die hen door de begeleider werd aangereikt $(n=93)$. Als begeleiders van deze groepjes werden ouderejaarsstudenten geselecteerd die in het voorafgaande jaar het hoogst gescoord hadden in een cursus inleiding in de psychologie en die tevens over goede communicatieve vaardigheden beschikten. Voorafgaande aan het experiment ontvingen deze begeleiders een vijfdaagse docententraining. Tijdens het experiment kwamen de student-begeleiders iedere week twee uur samen om het onderwijsmateriaal, dat in hun groepen aan de orde gesteld moest worden, te bespreken en er een mondeling examen over af te leggen. De studenten in alle drie condities moesten twaalf studie-eenheden doorwerken. Iedere week ontvingen alle studenten, van een onafhankelijk bureau, tien meerkeuze vragen, waarvan ze er minimaal acht goed moesten scoren wilden zij toegelaten worden tot de wekelijkse toets van de volgende studie-eenheid. Er waren drie herkansingen per eenheid. Op het einde van de cursus was er een afsluitend examen. De onderzoeksresultaten toonden aan dat de studenten begeleid door de ouderejaarsstudenten slechtere toetsprestaties leverden op het afsluitende examen dan de studenten in de andere condities. 


\section{Effecten van begeleiding door studenten binnen de context van probleemge- stuurd onderwijs}

In deze paragraaf zullen de resultaten besproken worden van peer tutoring onderzoek dat plaats heeft gevonden binnen de context van probleemgestuurd onderwijs. In die context ligt het accent meer op de zelfstandige kennisverwerving door de studenten zelf dan op kennisoverdracht door de docent. Studenten moeten, in de onderwijsgroep, zelf een groot aantal onderwijskundige funkties vervullen zoals bijvoorbeeld leerstof aan elkaar uitleggen, leerstof structureren, elkaar vragen stellen en kennis toepassen. De rol van de docent is in deze instructievorm minder sturend en directief. De docent-tutoren dienen een meer ondersteunende, faciliterende bijdrage te leveren aan het leerproces van de studenten.

De Volder, De Grave en Gijselaers (1985) onderzochten de leerprestaties van studenten in drie blokken van het eerstejaars curriculum van de Faculteit der Gezondheidswetenschappen aan de Rijksuniversiteit Limburg. Het eerste blok dat zij onderzochten was "Kennismaking met Sociale Gezondheidkunde". De twee andere blokken, "Gezondheidsvoorlichting en -opvoeding" en "Beleid en beheer van gezondheidszorginstellingen" waren introducties op mogelijke afstudeerrichtingen die de studenten later in hun studie konden kiezen. Aan de blokken namen gemiddeld zes student-assistenten en tien stafleden deel. De student-assistenten werden van te voren niet volgens bepaalde criteria geselecteerd, maar konden meedoen in volgorde van aanmelding. Ze ontvingen dezelfde meerdaagse tutortraining die stafleden krijgen als zij binnen de Faculteit der Gezondheidswetenschappen worden aangesteld. Na afloop van ieder blok werden de leerprestaties van de studenten gemeten met een toets bestaande uit juist-onjuist vragen die voornamelijk feitenkennis verondersteld werd te meten. De Volder et al. tonen aan dat onderwijsgroepen begeleid door een student-tutor in twee van de drie blokken geen significant verschillende prestaties op de bloktoets haalden vergeleken met onderwijsgroepen begeleid door een staflid-tutor. In het eerste blok "Kennismaking met Sociale Gezondheidkunde" werden echter wel significante verschillen gevonden, en wel ten gunste van de studenten begeleid door stafleden. De Volder en zijn collega's geven als een mogelijke verklaring voor dit resultaat dat de stafleden wellicht ander gedrag vertonen in de onderwijsgroepsbijeenkomsten. Zij zouden mogelijkerwijs hun taak op een meer klassieke wijze opvatten, namelijk door zo nu en dan kleine "colleges" aan de studenten van hun groep te geven. Hierover verschaffen de auteurs echter geen gegevens. Daamaast is onduidelijk waarom zij dat gedrag in de twee andere blokken niet vertonen. In hetzelfde onderzoek gingen genoemde auteurs ook na of de eigen leerprestaties van de student-tutor wellicht van invloed waren op de leerprestaties van de studenten op de bloktoets van blok "Kennismaking met Sociale Gezondheidkunde" Uit de resultaten blijkt dat er geen verschillen geconstateerd 
konden worden tussen studenten begeleid door "hoog presterende" vergeleken met "middelmatig presterende" student-tutoren. De prestaties van de studenten begeleid door de laatste groep studenten lagen zelfs hoger dan van de studenten begeleid door de "hoog presterende" studenten.

In een vervolgonderzoek constateerden De Grave, De Volder, Gijselaers en Damoiseaux (1990) in het daaropvolgende academische jaar in het eerstejaarsblok "Introductie op Gezondheidsvoorlichting en -opvoeding" eenzelfde beeld: geen verschillen tussen studenten en stafleden op een prestatiemeting. Evenmin vinden de onderzoekers verschillen tussen studenten begeleid door "expert student-tutoren" en "non-expert student tutoren". In dit onderzoek kwalificeerden de auteurs de expert tutoren als studenten uit een hoger leerjaar, te weten het derde, die zich specialiseren in de afstudeerrichting Gezondheidsvoorlichting en -opvoeding, en non-expert tutoren als derdejaars student-tutoren die zich richtten op een van de andere afstudeerrichtingen in de desbetreffende faculteit, bijvoorbeeld Verplegingswetenschappen of Beleid en beheer van gezondheidszorginstellingen.

In de Faculteit der Economische Wetenschappen van de Rijksuniversiteit Limburg vergeleken Gijselaers, Bouhuijs, Mulder en Mullink (1987) in twee eerstejaars blokken de leerprestaties van studenten die begeleid werden door een student met die begeleid door een staflid. Het experiment vond in twee opeenvolgende blokken plaats om mogelijke effecten over een langere termijn dan een blok te meten. Iedere student kreeg ò twee maal een staflid als tutor òf twee maal een student als tutor. Aan het experiment deden 10 ouderejaarsstudenten als student-tutor mee. De studenten werden geworven via een sollicitatieprocedure voor student-assistenten. Criteria voor selectie waren: affiniteit met probleemgestuurd onderwijs, tweede of derdejaars student economie zijn en bereid zijn om een tutortraining te volgen. De geselecteerden kregen een aanstelling als student-assistent en een tutortraining voorafgaande aan de eerste blokperiode. Gijselaers en zijn collega's onderzochten de leerprestaties van de studenten op de bloktoetsen die meteen na ieder blok afgenomen werden. De bloktoetsen bestonden uit negentig juist-onjuist vragen. Verschillende effecten werden gevonden. In het eerste van de twee opeenvolgende blokken constateerden de onderzoekers geen significante verschillen in de bloktoetsresultaten. In het tweede blok troffen zij wel tamelijk grote significante verschillen aan. Studenten begeleid door stafleden leverden betere leerprestaties. Uit de programma-evaluatiegegevens bleek dat de verschillen in leerprestaties op de twee bloktoetsen niet samenhingen met de moeilijkheidsgraad en kwaliteit van de bloktoetsen. Beide toetsen kregen van de studenten een gelijke beoordeling wat betreft aansluiting op de bestudeerde en behandelde leerstof. De verschillen in de bloktoetsresultaten lijken volgens de onderzoekers samen te hangen met de kwaliteit van de blokboeken. In het tweede blok werd negatiever geoordeeld over het blokboek. De onderzoekers constateerden dat er in 
beide blokken een significante correlatie bestaat tussen het oordeel van de studenten over het blokboek en de bloktoetsprestaties.

"Student-tutoren functioneren net zo goed, of slecht, als stiftutoren, zolang zij in een goed gestructureerd blok werken en als zij de beschikking hebben over een duidelijke tutorinstructie. Als dit niet het geval is verliezen zij (student-tutoren JM) op een gelijke wijze als hun studenten het overzicht over het blok en worden eveneens afhankelijk van de informatie uit het blokboek. Daardoor kunnen zij de discussies in de onderwijsgroep minder goed sturen dan staf-tutoren, die een kennisvoorsprong hebben op student-tutoren" (Gijselaers et al. (1987), p. 7).

De kwaliteit van het blokboek is volgens Gijselaers en zijn collega's derhalve bepalend voor de leerprestaties en de rol die de tutoren spelen bij de kennisverwerving van de studenten.

In de Faculteit der Rechtsgeleerdheid onderzochten Moust, De Volder en Nuy (1989) de effecten op het leren van studenten begeleid door studenttutoren vergeleken met diegenen die door staflid-tutoren werden begeleid. Voor het begin van het academische jaar 1986-1987 werden student-tutoren geselecteerd door middel van een open sollicitatieprocedure. Criteria voor selectie waren: affiniteit met probleemgestuurd onderwijs, interesse in groepsdynamische processen en redelijk goed inzicht in de leerstof van het eerste studiejaar. Tien studenten werden aangetrokken. Voorafgaande aan het eerste blok kregen zij een tweedaagse tutortraining die identiek was aan de training die alle stafleden ontvangen nadat zij een functie aanvaard hebben bij de Faculteit. Na afloop van ieder zesweeks eerstejaarsblok kregen alle studenten een summatieve bloktoets voorgelegd, die bestond uit zes essayvragen. Moust en zijn collega's gingen voor het laatste blok van het eerste jaar na of er verschillen in leerprestaties waren tussen studenten begeleid door staflidtutoren vergeleken met student-tutoren. $\mathrm{Zij}$ vonden dat de resultaten van de studenten begeleid door staflid-tutoren significant hoger waren dan de resultaten van studenten begeleid door student-tutoren. De verklaring die de onderzoekers voor dit resultaat gaven berust op de aanname dat essayvragen met hun open karakter een beroep doen op andere denkprocessen dan bijvoorbeeld meerkeuze- of juist-onjuist vragen. Bij deze laatste vormen van toetsing doet de student meer een beroep op zijn vermogen tot herinnering en herkenning ("recognition") van het antwoord. Bij essayvragen wordt daarentegen sterker een beroep gedaan op het vermogen van de student de nieuw verworven kennis te gebruiken en toe te passen ("retrieval"). Aansluitend bij de informatieverwerkingstheorie van Rumelhart \& Norman (1978), nemen de auteurs aan dat staflid-tutoren, op basis van hun vakinhoudelijke deskundigheid, beter dan student-tutoren in staat zijn de wijze waarop de studenten hun kennis geordend hebben te helpen wijzigen en te reorganiseren. 
Peer tutoring en studentgeleid onderwijs in probleemgestuurd onderwijs

\begin{tabular}{ll} 
onderzoeker(s) & $\begin{array}{l}\text { samenstelling } \\
\text { groepen }\end{array}$ \\
\hline Carsrud (1979) & $\begin{array}{l}16 \text { studentgeleide } \\
\text { groepen ( } \mathrm{N}=6) \mathrm{vs} .1 \\
\text { collegegroep ( } \mathrm{N}=326) \\
\text { vs. niet-begeleide groe- } \\
\text { pen (aantal en omvang } \\
\text { niet bekend) }\end{array}$
\end{tabular}

wijze van toetsing resultaten

Bloxom, Caul,

Fristoe \&

Thompson (1986)

onbekend aantal studentgeleide groepen

vs. I collegegroep

$(\mathrm{N}=215)$

De Volder, De

Grave \& Gijselaers (1985)

17 studentgeleide groepen $(\mathrm{N}=9$ )

vs. 28 docentgeleide groepen $(\mathrm{N}=9)$

11 studentgeleide groepen $(\mathrm{N}=10)$

vs. 6 docentgeleide groepen $(\mathrm{N}=10)$

Gijselaers, Bou- 20 studentgeleide huijs, Mulder \& Mullink (1987)

\& Nuy (1989) groepen $(\mathrm{N}=10)$ vs. 26 docentgeleide groepen $(\mathrm{N}=10)$

10 studentgeleide groepen $(\mathrm{N}=10)$ vs. 10 docentgeleide groepen $(\mathrm{N}=10)$ meerkeuze vragen docentbegeleide groep betere prestaties

meerkeuze vragen geen verschillen

juist-onjuist vragen 3 onafhankelijke metingen; 2 maal geen verschil, 1 maal docentgeleide groepen betere prestaties

juist-onjuist vragen geen verschillen

juist-onjuist vragen 2 onafhankelijke metingen; 1 maal geen verschil, 1 maal docentgeleide groep betere prestaties

essayvragen

docentgeleide groepen betere prestaties

Samenvattend kan opgemerkt worden dat er, in het hoger onderwijs, weinig onderzoek heeft plaatsgevonden naar cognitieve effecten van peer tuto- 
ring. Uit de schaarse onderzoeksresultaten blijkt dat de bevindingen niet eensluidend zijn. Studenten begeleid door ouderejaars behalen veelal dezelfde leerprestaties als studenten begeleid door stafleden. Er worden in een enkel geval echter ook slechtere leerresultaten gevonden. Tabel 2.2 geeft een overzicht van de verschillende onderzoeksuitkomsten van peer-tutoring en studentgeleid onderwijs binnen de context van probleemgestuurd onderwijs.

\section{Beperkingen van bovengenoemd onderzoek}

Geconcludeerd kan worden dat effecten van studentgeleid onderwijs in het hoger onderwijs, lastig te interpreteren zijn. Verschillende onderzoekers rapporteren in veel gevallen geen, soms positieve, in een enkele geval negatieve effecten van dit soort onderwijs. Hoe zijn de verschillen in uitkomsten van de hier gerapporteerde studies te verklaren? Eén van de redenen is wellicht dat de onderwijsvormen die met elkaar vergeleken worden, vaak zo sterk van elkaar verschillen dat men niet meer weet welke onderwijsaspecten eigenlijk vergeleken worden. Zowel de groepsomvang als de wijze waarop de doceertaken van de studenten gestructureerd zijn, verschillen in de gerapporteerde onderzoeken sterk van elkaar. Hovey et al. (1963) en Beach (1974) werkten bijvoorbeeld met groepjes van ongeveer vijf personen in de docentloze conditie; Bloxom et al. (1975) en Ten Cate (1986) hadden ongeveer tien personen in elk van de groepen geplaatst. Groepsomvang kan derhalve efficten op de interactie tussen de studenten hebben gehad en daarmec op de leerprestaties. Vaak wordt niets vermeld over de omvang van de groep die het hoorcollege volgde, zie bijvoorbeeld de studies van Blunt \& Blizzard (1973) en Beach (1974). Ook de wijze waarop de doceertaken van de studenten gestructureerd zijn, verschilt sterk. Hovey et al. (1963) en Ten Cate (1986) werkten met een sterk gestructureerde benadering; Beach $(1974,1983)$ en Carsrud (1979) laten de studenten meer zelf bepalen hoe ze de leerstof behandelen.

Een andere oorzaak voor de elkaar tegensprekende bevindingen zou gelegen kunnen zijn in het gegeven dat de feitelijk verrichte onderzoeken methodologisch sterk van elkaar verschillen. Zo wordt (quasi)-experimenteel onderzoek en veldonderzoek met elkaar vergeleken. Ook wordt onderzoek met elkaar vergeleken waarbij de metingen op verschillende tijdstippen plaatsvonden: direct na de lesperiode of enkele weken later. In veel studies werden de leerprestaties gemeten met behulp van verschillende toetsinstrumenten, bijvoorbeeld meerkeuze vragen (Beach, 1974; Blunt \& Blizzard, 1973; Carsrud, 1979) of een mix van essay- en meerkeuzevragen (Hovey et al., 1963) of met essayvragen (Clement, 1971). Ten Cate (1986) wijst in zijn proefschrift ook op vele onderzoekstechnische tekortkomingen. Vaak wordt nagelaten iets te rapporteren over de psychometrische kenmerken van het instrument en wordt er slechts schaarse informatie verstrekt over de precieze aard van de me- 
tingen. Kenmerkend voor de meeste studies is dat zij enkel gericht zijn op de uitkomsten van de experimentele manipulatie, zonder dat duidelijk wordt wat zich in de controleconditie heeft afgespeeld, en hoe dat de uitkomsten beïnvloed heeft (Beach, 1974, 1983; Blunt \& Blizzard, 1973). Er is slechts één studie bekend waarbij de leerprestaties van de studenten longitudinaal, weliswaar driemaal met één en dezelfde, open vraag is gemeten (Clement, 1971). Voor nogal wat van de gerapporteerde resultaten, betrekking hebbende op niet-cognitieve onderzoeksgegevens, lijkt te gelden dat de studenten voor het eerst in hun studie met (docentonafhankelijk) groepsonderwijs, in aanraking kwamen. Derhalve mag niet uitgesloten worden dat er sprake kan zijn van "Hawthorne" effecten als gevolg waarvan studenten zich meer inzetten dan op de lange duur gebruikelijk zou zijn. Opvallend is tenslotte dat veel studies sterk empirisch van aard zijn en dat nauwelijks theoretische verklaringen worden gegeven voor de gelijkwaardige, betere of slechtere leerprestaties van de betrokken studenten. Slechts zijdelings wordt gerefereerd aan theoretische constructen die de gevonden resultaten kunnen verklaren. Geconstateerd kan dan ook worden dat veel onderzoek naar studentgeleid onderwijs in het hoger onderwijs, gekenmerkt kan worden met de algemene conclusie waarmee Devin-Sheehan, Feldman en Allen in 1976 de "state of the art" op dit terrein in het primair en secundair onderwijs typeerde:

"Rather than identifying critical issues and problems based upon theoretical considerations, most studies to date have been designed only to determine if the particular tutoring situation is efficacious" (p. 377).

\section{Verklaringen voor de mogelijke effectiviteit van studentgeleid onderwijs}

De bevinding dat de leerprestaties van studenten begeleid door stafleden vaak niet verschillen van de leerprestaties van studenten begeleid door (ouderejaars) studenten is op zichzelf opmerkelijk. Men zou er immers van uit mogen gaan dat staf-docenten over meer kennis en ervaring beschikken dan student-docenten en op grond daarvan beter in staat zijn studenten vooruit te helpen.

In de literatuur over studentgeleid onderwijs worden slechts sporadisch pogingen gedaan effecten van dat onderwijs theoretisch te onderbouwen. De schaarse theoretische noties die beschikbaar zijn, gaan daarbij ook nog uit van de veronderstelling dat studentgeleid onderwijs altijd positievere effecten op het leren heeft dan docentgeleid onderwijs, hoewel, zoals gezegd, er empirisch niet altijd aanleiding is voor een dergelijke hypothese. We zullen de literatuur op dit terrein niettemin tamelijk uitgebreid bespreken omdat ze toch wel suggesties bevat met betrekking tot mogelijke verschillen in aanpak tussen docenten en studenten; het object van dit proefschrift. 
De hypothesen die men aantreft, hebben verschillende uitgangspunten. Eén hypothese berust op de gedachte dat studenten, wanneer zij docentonafhankelijk onderwijs krijgen, meer en beter met elkaar zullen communiceren over de leerstof (Powell, 1974). Een tweede theorie concentreert zich op de veronderstelling dat de kennisstructuur van de student-docent sterk lijkt op de kennisstructuur van zijn medestudenten waardoor de onderlinge informatieuitwisseling gemakkelijker verloopt (Cornwall, 1980). Een derde veronderstelling is gebaseerd op de idee dat studenten, in een onderwijscontext waarin ze begeleid worden door studiegenoten, sterker gemotiveerd worden vorr hun studie. Deze sterkere motivatie zou het gevolg zijn van een meer persoonlijk contact tussen de studenten en de student-docent (Sarbin, 1976). Achtereenvolgens zullen nu deze verschillende veronderstellingen meer uitgebreid besproken worden.

De eerste hypothese berust op de gedachte dat studenten meer, openhartiger en beter met elkaar over de leerstof communiceren wanneer ze docentonafhankelijk onderwijs krijgen. Studenten blijken in studentgeleide onderwijssituaties, volgens eerder gerapporteerde onderzoeken (Beach, 1974; Collier, 1966; Fransson, 1977; Ten Cate, 1986), actiever deel te nemen aan het onderwijsleerproces. Deze actievere deelname lijkt het gevolg te zijn van het feit dat de spreektijd die normaliter door de docent in beslag wordt genomen, bij diens afwezigheid, beschikbaar is voor de studenten. Bender (1983) en G. Webb (1983) vonden in hun onderzoeken naar docentgeleide en docentloze groepen dat docenten resp. 44 tot $61 \%$ van de spreektijd vulden in de discussiegroepen die zij leidden. Ook Powell (1974) constateerde dat de participatie van studenten aan groepsdiscussies veel groter werd wanneer er geen docent aanwezig was. Bij een kwalitatieve analyse van zijn materiaal (bestaande uit bandopnamen) vond Powell bovendien dat bij de docentgeleide bijeenkomsten de discussies veelal het karakter hadden van informatieverstrekking, terwijl in de studentgeleide bijeenkomsten het geven van meningen vaker voorkwam. Dit leereffect van daadwerkelijk onderwijzen wordt ook geconstateerd in peer teaching situaties als 'cooperative' en 'collaborative' learning. In verschillende studies naar de kenmerken van interactie tussen studenten in coöperatieve leersituaties in het primair en secundair onderwijs, vindt N.M. Webb $(1982,1989)$ dat vooral gedragingen als "vragen stellen" en "uitleg geven" een positief effect hebben op de leerprestaties van die studenten die deze gedragingen uitvoeren. Daarbij is vooral van belang dat de informatie die gegeven wordt aansluit op de vraag en de mate waarin de uitleg die gegeven wordt uitgewerkt, geëlaboreerd, is. Uitleg waarbij slechts verwezen wordt naar bronnen waar het antwoord gevonden kan worden, of uitleg waarbij niet meer dan feitelijke informatie verstrekt wordt zonder nadere uitwerking, heeft een negatief effect op de leerprestaties van de student die om uitleg vraagt. Uitleg die bestaat uit argumenten, voorbeelden of een beschrijving van de wijze waarop een probleem opgelost kan worden (door N.M. 
Webb "high-level elaborations" genoemd) leidt zowel voor degene die om uitleg vraagt als voor degene die deze geeft tot betere leerprestaties. N.M. Webb (1989) verklaart deze positieve leereffecten uit het feit dat degene die hulp biedt, de leerstof moet verhelderen, organiseren en reorganiseren.

"In the process of clarifying and reorganizing the material, the helper may discover gaps in his or her own understanding or discrepancies with others' work or previous work. To resolve these discrepancies, the helper may search for new information and subsequently resolve those inconsistencies, thereby learning the material better than before. Furthermore, when an explanation given to a team-mate is not successful ..., the helper is forced to try to formulate the explanation in new or different ways. This may include using different language, such as translating unusual of unfamiliar language into familiar language, generating new or different examples; linking examples to the target student's prior knowledge or work completed previously; using alternative symbolic representations of the same material and translating among different representations of the same material" (p. 29).

De kwantitatief en kwalitatief sterk verbeterde interactie tussen studenten onderling in docentloze groepen geven uiteraard maar beperkt inzicht in de processen die zich tussen de student-docent en zijn medestudenten afspelen.

Een tweede veronderstelling die in de literatuur gevonden kan worden gaat uit van de veronderstelling dat de kennisstructuren van de docent-student en studenten sterk op elkaar lijken, waardoor de informatie-uitwisseling gemakkelijker verloopt. Cornwall (1980) noemt kennisstructuren die op elkaar lijken 'cognitief congruent'. Doordat studenten die elkaar onderwijzen, informatie uitwisselen op basis van ongeveer hetzelfde kennisniveau zou de studentdocent gemakkelijker dan een docent in staat zijn de voorkennis van "zijn" studenten in te schatten en hierop aan te sluiten. Ook zou hij eerder en beter hun cognitieve problemen onderkennen en zou hij "omdat hij hun taal meer spreekt" gemakkelijker leerstof, zonder vakjargon, aan zijn medestudenten kunnen uitleggen. Uitgaande van deze cognitieve nabijheid tussen peers meent Comwall dat de peer-teacher:

"as a fellow leamer is almost bound to be at the same conceptual level as that of his peers; he will be very likely only to refer to linking concepts, relationships and facts that are part of the learner's knowledge; he will use language at the same level as his peers" (p. 84)

en

"one can conclude that the most appropriate and potentially effective use of (peer teaching) is to stimulate and promote the relatively small-scale restructuring and tuning of the learner's semantic network; and for this purpose the peer teacher is likely to be at least as effective as the regular teacher ..." (pp. 84-85). 
Ook Webb (1989) is van mening dat studenten die in kleine groepen werken voldoende uitgerust zijn om elkaar effectief hulp te geven. Zij hebben het vermogen om elkaar op het juiste moment en in begrijpelijke taal informatie te verschaffen.

"Because they are working on the same problems at the same time, they are "well tuned into" each others' problem-solving processes in a way that a teacher may not be and so can understand where team-mates go wrong and what they do not understand. Students also share similar language and can translate difficult vocabulary and expressions for each other" (p. 25).

Een derde mogelijke verklaring die naar voren gebracht is, veronderstelt dat studenten meer gemotiveerd raken door de wijze waarop de studentdocent in de onderwijssituatie optreedt. De verklaring heeft betrekking op de manier waarop docenten en studenten met elkaar omgaan. De relatie tussen stafleden en studenten is, in principe, er een van ongelijkheid. $\mathrm{Er}$ is een zekere afstand tussen stafleden en studenten. Ze verschillen in leeftijd en opleiding. Ze vervullen rollen in het onderwijs die in zekere zin tegengesteld zijn. Studenten ervaren stafleden vaak als een autoriteit, stafleden nemen ook vaker een zekere distantie ten opzichte van studenten in acht (Peters, 1969). Student-docenten en studenten hebben echter vaak gemeenschappelijke interesses voor bijvoorbeeld muziek, sport en film. Ze delen vaker dezelfde normen en waarden ten opzichte van allerlei verschijnselen in de samenleving. Student-docenten lijken zich gemakkelijker te kunnen verplaatsen in de leefwereld van de studenten. Ze kunnen zich voorstellen hoe studenten leven en welke opvattingen ze van hun studie hebben. Als leeftijdsgenoten met iets meer opleidingservaringen kunnen ze zich een goed beeld vormen van de moeilijkheden en mogelijkheden die studenten hebben tijdens hun studie. Hiervan geven ze blijk door hun waardering voor de bijdragen van de studenten, in de taal van hun medestudenten, kenbaar te maken. Wanneer studenten problemen ondervinden met hun studie laten ze hen sneller merken dat het wel mee valt en dat het probleem gezamenlijk wel opgelost wordt (Sarbin, 1976).

Zoals gezegd, gaan deze veronderstellingen er impliciet van uit dat studentgeleid onderwijs beter is dan onderwijs gegeven door docenten. De empirie spreekt dat echter soms tegen, zoals blijkt uit het overzicht gegeven in voorgaande paragrafen. Interessant is dat in de literatuur met geen woord gerept wordt over waarom in sommige studies studenten begeleid door docenten het beter doen. Wij offreren hiervoor de volgende hypothese: docenten beschikken over meer kennis en ervaring dan student-begeleiders. Docenten hebben een langere leerweg doorlopen en hebben zich veelal gespecialiseerd op het terrein waarin zij doceren. Ze hebben ook al eerder meerdere malen de onderwerpen onderwezen die de studenten aangeboden 
kregen. Onderwijzen lijkt een sterke invloed te hebben op het onthouden en structureren van kennis (Annis, 1983). Het lijkt niet onjuist te verwachten dat docenten beschikken over een hechtere en meer flexibele kennisstructuur dan student-docenten en daardoor beter in staat geacht mogen worden hun studenten te helpen bij hun studie. Student-docenten zullen daarentegen een nauwelijks meer gedifferentieerde kennisstructuur bezitten dan de studenten die zij begeleiden. In studentgeleide groepen zou men daarom een "poolingof-ignorance" effect (Cornwall, 1980) verwachten met betrekking tot de mogelijkheden van student-begeleiders om medestudenten te helpen. Doordat de kennisoverdracht van docenten beter lijkt te zijn leren docent-begeleide studenten meer en zijn hun leerprestaties hoger.

Ter verklaring van het feit dat vaak géén verschillen worden gevonden, zullen wij een altematieve hypothese voorleggen: de "compensatie" hypothese. Deze hypothese gaat uit van de gedachte dat studenten, begeleid door studiegenoten compensatie zoeken voor de, in hun ogen, wellicht "zwakkere begeleiding" van medestudenten. Verschillende onderzoekers rapporteren dat de studenten in de studentgeleide onderwijssituatie meer tijd en energie in hun studie steken (Collier, 1966, 1983; Rudduck, 1978), actiever naar informatie zoeken en zich breder oriënteren op het terrein van hun studie (Beach, 1983; Chambers, 1983; Hovey et al., 1963; Rodger, 1983). Deze extra inspanning van de studenten verklaren deze onderzoekers op basis van een sterkere motivatie bij de studenten in de studentgeleide groepen. De studenten in deze groepen zouden zich meer verantwoordelijk voelen voor hun eigen leren, of meer geïnteresseerd zijn in het onderwerp dat zij moeten bestuderen. Een alternatieve verklaring voor het fenomeen dat studenten in studentgeleide groepen zich extra gaan inspannen, zou de volgende kunnen zijn: studenten in de studentgeleide onderwijssituatie beseffen dat de vakinhoudelijke en didactische deskundigheid van hun student-begeleider minder hoog is dan de deskundigheid van docenten. Door extra studie-inspanningen te verrichten proberen zij deze, in hun ogen, ongunstige onderwijssituatie te compenseren. In de literatuur betreffende studentgeleid onderwijs wordt deze veronderstelling niet expliciet teruggevonden. Sporadisch worden enkele citaten aangetroffen waaruit afgeleid zou kunnen worden dat studenten niet altijd even gelukkig zijn met het feit dat zij onderwijs ontvingen, verzorgd door een student-docent. Zo wijst Ten Cate (1986) erop dat enkele studenten opmerkten dat "de peer teachers geen stof kunnen behandelen die ze zelf niet echt goed snappen. Enig inzicht in de informatica is wel nodig om dit onderwerp uit te kunnen leggen. Ik vond dit onderwerp niet geschikt voor peer teaching" (Ten Cate, 1986, p. 180). De studenten vragen dan ook om additionele ondersteuning in de vorm van colleges door of consultaties van "echte" docenten. Ook Whitman (1988) vermeldt een onderzoek van Slotnick, Jager en Schure (1981) waarin studenten die begeleid werden door medestudenten kenbaar maakten dat zij bang waren om deel te nemen aan werkgroepen onafhankelijk van de 
hoorcolleges die door de docent verzorgd werden. Deze studenten waren van mening dat de docent zijn verantwoordelijkheid ontweek "espousing the belief that only the legitimate professional authority can deliver 'officially authentic' education' (Whitman, 1988, pg. 30). Schermerhorn, Goldschmid en Shore (1976) rapporteren tenslotte eveneens dat de studenten die meededen aan hun onderzoek naar studentgeleid onderwijs soms ook ontevreden waren met het feit dat ze onderwezen werden door medestudenten in plaats van door stafleden.

\section{Samenvatting}

In dit hoofdstuk werd een overzicht gegeven van onderzoek naar, en verklaringen voor, de mogelijke effectiviteit van studentgeleid onderwijs. Eerst werd aandacht besteed aan de verschillende vormen waarin, en benamingen waaronder, studentgeleid onderwijs in het hoger onderwijs kan voorkomen. Vervolgens werd onderzoek gepresenteerd naar de effecten van peer teaching en peer tutoring. De resultaten van onderzoek naar de niet-cognitieve effecten van deze vormen van studentgeleid onderwijs zijn redelijk overeenstemmend. Studentgeleid onderwijs motiveert en activeert de studenten tot zelfstandig studiegedrag. De studenten bestuderen meer en diepgaander de literatuur die met een bepaald studie-onderwerp samenhangt, nemen vaker deel aan het onderwijs en vinden hun studie bevredigender. De resultaten van onderzoek naar cognitieve effecten van studentgeleid onderwijs zijn daarentegen niet eensluidend. Een aantal onderzoekers vindt geen verschillen in studieresultaten tussen studentgeleide en docentgeleide groepen. Andere studies daarentegen rapporteerden hetzij betere hetzij slechtere leerprestaties van de studenten in de zelfstandig werkende groepen. Vervolgens werd het onderzoek naar studentgeleid onderwijs in de probleemgestuurde onderwijscontext beschreven. Ook in dat domein werden geen eensluidende effecten gevonden. Geconcludeerd werd dat het onderzoek naar cognitieve effecten van studentgeleid onderwijs echter verschillende beperkingen had. Zo was de controleconditie in verschillende experimenten vaak slecht gedefinieerd en schoot de rapportage van de resultaten en de condities waaronder $\mathrm{zij}$ werden verkregen vaak tekort. Tot slot van dit hoofdstuk werden enige mogelijke verklaringen voor effecten van studentgeleid onderwijs beschreven.

\section{De inhoud van dit proefschrift}

In dit proefschrift zal, binnen de context van probleemgestuurd onderwijs, nagegaan worden in hoeverre studentgeleid onderwijs, in termen van leerprestaties en andere indicatoren voor goed onderwijs, verschilt van docentgeleid onderwijs. De verschillende verklaringen geopperd voor de, veelal geconsta- 
teerde, afwezigheid van verschillen in leerprestaties zullen onderzocht worden.

In het volgende hoofdstuk worden eerst de onderzoeksopzet en de onderzoeksinstrumenten beschreven.

In Hoofdstuk 4 worden de resultaten besproken van een vergelijking van de leerprestaties van eerstejaars studenten begeleid door student-tutoren en studenten begeleid door staflid-tutoren. Daarbij worden resultaten behaald op de bloktoets geanalyseerd.

De veronderstelling dat studenten begeleid door student-docenten harder werken (bijvoorbeeld om de "zwakkere" begeleiding van hun tutor te compenseren), wordt geanalyseerd in Hoofdstuk 5. De hoeveelheid zelfstudie van een student kan beschouwd worden als een belangrijke variabele die intermedieert tussen docentgedrag en leerprestaties. Studietijd is een belangrijke indicator van de mate waarin de studenten inspanningen leveren om een voldoende leerresultaat te bereiken. Onderzocht is of studenten begeleid door student-tutoren meer, evenveel of minder tijd besteden aan zelfstudie voor de leerdoelen van de onderwijsgroep dan de studenten begeleid door staflidtutoren.

Aansluitend op deze prestatie- en studietijdmetingen wordt onderzocht of de andere veronderstellingen naar de effectiviteit van studentgeleid onderwijs de prestaties van de studenten beïnvloeden. Nagegaan zal worden of studenttutoren hun relatieve achterstand op kennisgebied en didactische ervaring compenseren. Om de verschillende verklaringen voor de effectiviteit van studentgeleid onderwijs te onderzoeken is een vragenlijst ontwikkeld. In Hoofdstuk 6 worden de resultaten van deze vragenlijst besproken. Gerapporteerd wordt of student-tutoren zich op een andere wijze in een onderwijsgroep gedragen dan staf-tutoren.

In Hoofdstuk 7 ten slotte zal het onderscheid student-staf tutor als de belangrijkste onafhankelijke variable verlaten worden en zal onderzocht worden of er specifieke activiteiten van tutoren (los van de vraag of het studentdan wel staf-tutoren zijn) te onderscheiden zijn die leiden tot extra studieinspanningen en hogere studieprestaties van de studenten. 


\section{Globaal overzicht van het onderzoek}

\section{Inleiding}

In dit hoofdstuk wordt beschreven op welke wijze het onderzoek, waarvan de resultaten in dit proefschrift gerapporteerd worden, uitgevoerd werd. Het onderzoek betreft twee veldexperimenten die plaatsvonden in het eerste cursusjaar van de studie Nederlands Recht aan de Faculteit der Rechtsgeleerdheid. In de volgende paragraaf zullen de onderwijsblokken beschreven worden waarin het onderzoek uitgevoerd werd. In de daarop volgende paragraaf wordt de wijze waarop het onderzoek werd opgezet, besproken. De verschillende onderzoeksinstrumenten die in het onderzoek gebruikt werden, worden daarna beschreven.

\section{Beschrijving van het onderwijsblok waarin het onderzoek plaatsvond}

Het onderzoek werd uitgevoerd bij eerstejaarsstudenten rechten aan de Rijksuniversiteit Limburg in het cursusjaar 1988/89. Het onderwijs in de propedeuse werd aangeboden in vier onderwijsblokken, elk van acht weken, steeds gewijd aan één bepaald thema. Tussen de blokperiodes, of soms binnen een blokperiode, waren onderwijsvrije periodes ingeroosterd, waarin de studenten een opstel moesten schrijven over een juridisch onderwerp. Figuur 3.1 geeft een schematisch overzicht van het onderwijs in de propedeuse in het studiejaar 1988/89. 
Het onderzoek werd verricht in het derde en vierde onderwijsblok omdat de studenten dan redelijk vertrouwd zouden zijn met de gang van zaken binnen probleemgestuurd onderwijs.

Het onderwijs in de derde onderwijsperiode betrof onderwerpen die samenhingen met het thema "Rechtshandeling". Binnen dit thema werd aandacht besteed aan de rechtshandeling in het privaat- en het publiekrecht.

Figuur 3.I

Schematisch overzicht onderwijs propedeutisch jaar FdR, studiejaar 1988/1989

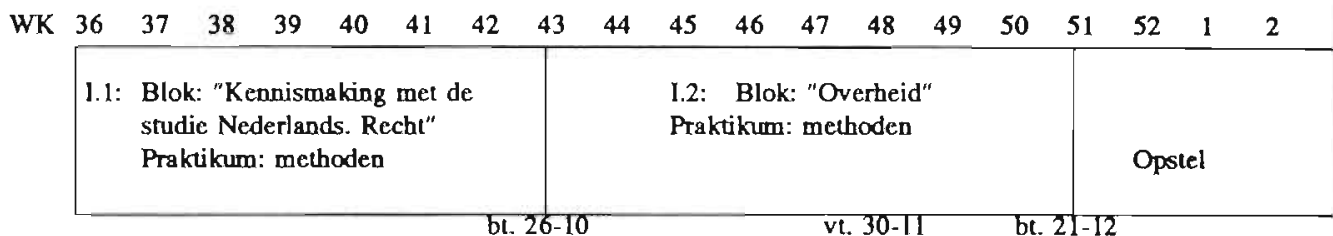

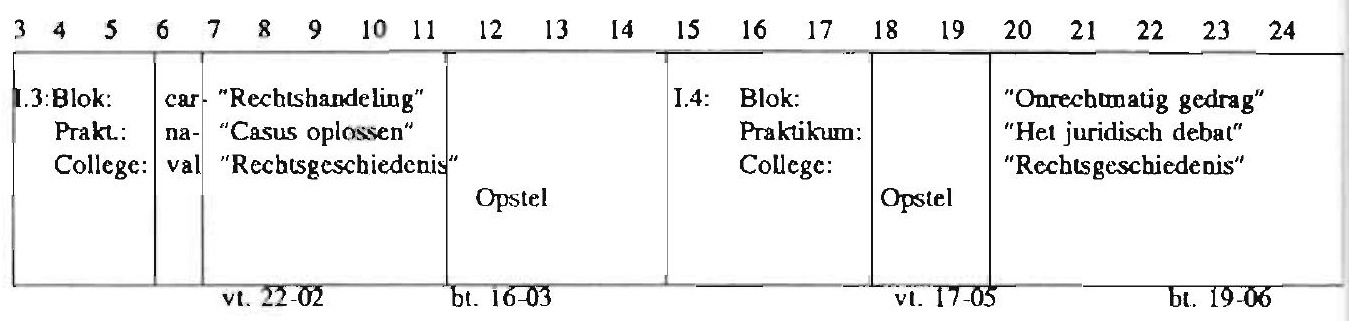

bt. - bloktoets
vt. - voorgangstoets

Twee van de voor het Nederlandse privaat- en bestuursrecht karakteristieke rechtshandelingen kwamen aan de orde. "de overeenkomst" en "de beschikking". Aan de hand van subthema's als "totstandkoming" en "uitvoering" werden de studenten ingeleid in deze onderwerpen. Beide onderwerpen werden echter ook in een breder verband geplaatst. De beschikking werd bijvoorbeeld ook behandeld tegen de achtergrond van andere publiekrechtelijke begrippen, waaronder met name de wet. De overeenkomst kwam bovendien aan de orde als een van de bronnen van verbintenissen, naast met name de onrechtmatige daad. In geringe mate werd tevens aandacht besteed aan de historische dimensie van het thema en aan een onderlinge vergelijking van het recht in verband met overeenkomst en beschikking. Het blokboek dat de studenten voor het behandelen van deze onderwerpen kregen, omvat, naast 
een korte inleiding, drieëndertig taken. Om het blok zo veel mogelijk tot een eenheid te maken, kozen de docenten die het blokboek ontwikkelden voor een doorlopend verhaal.

Het vierde onderwijsblok, "Onrechtmatig gedrag" genaamd, had onderwerpen op het gebied van het strafrecht en het burgerlijk recht. In het strafrechtelijke deel werd vooral aandacht besteed aan de structuur van het strafbaar feit. Aan de orde kwamen onderwerpen als: legaliteitsbeginsel, bestanddeel of fait d'excuse, de gedraging, causaliteit, wederrechtelijkheid, schuldbestanddelen en schulduitsluitingsgronden. In het civielrechtelijke deel kwamen de voorwaarden voor aansprakelijkheid op grond van onrechtmatige daad aan de orde. In het slotdeel werd een vergelijking gemaakt tussen de onrechtmatige daad en het strafbaar feit. Het blokboek bestond uit drieëndertig, grotendeels van elkaar losstaande, taken.

Het onderwijs in beide blokken bestond uit twee onderwijsgroepsbijeenkomsten per week van elk twee uur. Daarnaast vond er in het derde blok een practicum "Casus oplossen" plaats, waarvoor de studenten drie uur per week in groepen van plus/minus vijfentwintig studenten bijeenkwamen, en was er wekelijks een college "Rechtsgeschiedenis" van twee uur. In de vierde blokperiode was wekelijks een practicum "Het juridisch debat", waarvoor de studenten een uur per week in groepjes van acht à tien personen bijeenkwamen en werd het college rechtsgeschiedenis voortgezet. Naast deze structurele onderwijsactiviteiten waren er sporadisch enkele overzichtscolleges en vragenuurtjes die betrekking hadden op de onderwerpen van het blokthema. Ieder blok werd afgesloten met een toets over alle, via het blokboek, aangeboden onderwerpen en de leerstof die behandeld werd in het college rechtsgeschiedenis, alsmede de daarvoor verplichte literatuur.

\section{Opzet van het onderzoek}

Het onderzoek werd in twee blokken uitgevoerd, vooral om na te kunnen gaan hoe stabiel de resultaten, verkregen in één blok, zouden zijn. Tijdens het onderzoek werd dezelfde populatie studenten gestratificeerd aselect toegewezen aan een experimentele conditie (begeleiding door student-tutoren) of een controle conditie (begeleiding door docent-tutoren). Hieronder wordt beschreven hoe de studenten over het onderzoek werden geïnformeerd en hoe zij werden ingedeeld in de onderwijsgroepen, hoeveel student-tutoren en stafleden-tutoren bij het onderzoek betrokken waren en hoe de voorbereiding van deze tutoren op hun taak was. 


\section{Proefpersonen}

Voorafgaande aan het onderzoek, tijdens het tweede onderwijsblok, werden alle eerstejaarsstudenten mondeling en schriftelijk geïnformeerd dat in het derde en vierde onderwijsblok een onderzoek zou plaatsvinden naar wat genoemd werd "de kwaliteit van het juridisch onderwijs" (Zie Bijlage 3.1).

\section{Samenstellen van de onderzoeksgroepen}

Voor het studiejaar 1988 - 1989 hadden zich, blijkens een lijst van de studentenadministratie van het Buro Onderwijs van de Faculteit, 366 eerstejaarsstudenten ingeschreven. Onbekend was het aantal eerstejaarsstudenten uit het curriculumjaar 1987 - 1988 die de blokken 1.3 of 1.4 over wilden doen omdat zij op de bloktoets en de herkansingen tijdens dat studiejaar niet geslaagd waren. Deze zogeheten herkansers waren namelijk niet verplicht aan het onderwijs deel te nemen. Zij konden zich individueel, los van het onderwijsprogramma, op de toets voorbereiden. Herkansers die het onderwijsprogramma wel wilden volgen, d.w.z. deel wilden nemen aan de onderwijsgroepen van het desbetreffende blok, moesten zich daartoe aanmelden bij het Buro Onderwijs. Helaas deden niet alle studenten dat tijdig. Anderen lieten niet weten aan het Buro Onderwijs dat ze inmiddels de herkansingstoets van december 1988 behaald hadden en dat ze derhalve niet meer geplaatst hoefden te worden in een onderwijsgroep van het betreffende blok.

Voorafgaande aan het blok "Rechtshandeling" beschikte de administratie van Buro Onderwijs over 408 potentieel belangstellenden voor dat blok, namelijk 366 eerstejaars en 42 herkansers. Deze studenten werden verdeeld over 37 onderwijsgroepen bestaande uit 11 personen elk. Voor de indeling van de onderwijsgroepen werd de volgende procedure gevolgd. Elke onderwijsgroep werd conform de samenstelling naar leeftijd en geslacht van de eerstejaarsgroep ingedeeld. Elke onderwijsgroep werd op de volgende wijze samengesteld: 2 vrouwen jonger dan 20 jaar, 2 mannen jonger dan 20 jaar, 2 vrouwen van 20-24 jaar, 2 mannen van 20-24 jaar, 1 man of vrouw van 24 tot 30 jaar, een man of vrouw ouder dan 30 jaar en 1 herkanser. Vervolgens werden de studenten aselect toegewezen aan de verschillende onderwijsgroepen.

Tijdens de uitvoering van het onderwijs in blok 1.3 bleek dat 51 van de 408 ingedeelde studenten niet deelnamen aan het onderwijs van dit blok. Voor het overgrote deel waren dit eerstejaarsstudenten die hun studie inmiddels hadden gestaakt maar dit niet hadden doorgegeven aan Buro Onderwijs. Ook waren er een aantal herkansers, die de toets van dit blok wel moesten overdoen maar, ondanks inschrijving, bij nader inzien geen onderwijsgroepen wilden volgen. Tenslotte was een klein aantal studenten, die geen onderwijs in dit blok meer hoefde te volgen, toch abusievelijk in dit blok ingedeeld.

Voorafgaande aan het blok "Onrechtmatig gedrag" beschikte de administratie van Buro Onderwijs over 374 potentieel belangstellenden voor het 
blok "Rechtshandeling", namelijk 340 eerstejaars en 34 herkansers. Deze studenten werden verdeeld over 34 onderwijsgroepen bestaande uit 11 personen elk. Voor de indeling van de onderwijsgroepen werd dezelfde procedure gevolgd als beschreven bij blok 1.3. Tijdens de uitvoering van het onderwijs bleek dat slechts enkele eerstejaarsstudenten niet meer aan het onderwijs deelnamen, omdat zij met hun studie gestopt waren.

De groep tutoren die in beide blokken de onderwijsgroepen zou begeleiden bestond uit stafleden, student-assistenten, onderwijsmedewerkers en assistenten-in-opleiding van de Faculteit der Rechtsgeleerdheid. Het onderzoek besproken in deze studie is gericht op de onderwijsgroepen die begeleid worden door student-tutoren dan wel stafleden-tutoren, dus met uitsluiting van onderwijsmedewerkers en assistenten-in-opleiding. Alle tutoren werden aselect toegewezen aan één of meer onderwijsgroepen conform de indelingsprocedures van de Faculteit.

De student-assistenten die zouden optreden als student-tutor in een of beide onderwijsblokken waarin het onderzoek plaatsvond, waren door het Buro Onderwijs van de Faculteit aan het begin van het academisch jaar voor de betreffende blokken ingedeeld. Deze student-assistenten waren door een sollicitatiecommissie van de Faculteit aan het eind van het voorgaande studiejaar geselecteerd uit studenten die belangstelling hadden voor deze functie. Als selectiecriteria werden gehanteerd: goede resultaten tijdens de studie, affiniteit met het Maastrichtse onderwijssysteem en bekwaamheid in het kunnen begeleiden van groepen.

Nadat de studenten benoemd waren door de Faculteit ontvingen zij, zoals te doen gebruikelijk, kort voor het begin van het academisch jaar, een tweedaagse cursus ter voorbereiding op hun tutorrol. In deze cursus werd uitvoerig ingegaan op de leerpsychologische achtergronden van probleemgestuurd onderwijs en de taken die een tutor moet vervullen bij het begeleiden van een onderwijsgroep. Zo werd er aandacht besteed aan de wijze waarop de tutor het leren van studenten kan stimuleren en de wijze waarop de samenwerking tussen de studenten bevorderd kan worden. Ook het begeleiden van "moeilijke situaties in een onderwijsgroep" vormde onderdeel van deze tutortraining. $\mathrm{Na}$ deze cursus liep iedere student-assistent tijdens het eerste onderwijsblok "Kennismaking met de studie Nederlands Recht" wekelijks mee met een ervaren staflid-tutor. Dit staflid was ook de vaste begeleider van de studentassistent tijdens zijn tutorwerkzaamheden in de volgende onderwijsblokken van het propedeutisch jaar. De totale voorbereidingstijd van de studentassistenten op de tutorrol bedroeg ongeveer 40 uur.

De stafleden die een onderwijsgroep zouden begeleiden waren allen werkzaam in de rang van universitair docent of hoofddocent. Ze waren van verschillende vakgroepen afkomstig. Sommigen van hen waren al eerder in één 
van beide blokken, waarin het onderzoek zou plaatsvinden, opgetreden als tutor. Alle stafleden hadden kort na hun aanstelling in de faculteit een introductiecursus over probleemgestuurd onderwijs en de tweedaagse tutortraining gevolgd. De tweedaagse tutortraining bestond uit dezelfde componenten als de hierboven beschreven training voor de student-assistenten. Deze docentencursussen worden regelmatig georganiseerd voor nieuwe facultaire docenten voordat zij in het onderwijs ingeschakeld worden (Moust \& Schmidt, 1989).

In Tabel 3.1 en 3.2 wordt een overzicht gegeven van het aantal tutoren dat in verschillende functies aan de blokken "Rechtshandeling" en "Onrechtmatig gedrag" deelnam, het aantal onderwijsgroepen en het aantal daadwerkelijk participerende studenten in de onderwijsgroepen.

Een staflid en vijf student-assistenten traden in beide blokken op als tutor.

Tabel 3.1

Aantallen deelnemende tutoren, onderwijsgroepen en studenten in het blok "Rechtshandeling"

\begin{tabular}{lccc} 
tutoren & $\mathbf{n}$ & $\begin{array}{c}\text { aantal onder- } \\
\text { wijsgroepen }\end{array}$ & $\begin{array}{c}\text { aantal } \\
\text { studenten }\end{array}$ \\
\hline stafleden & 7 & 14 & 134 \\
student-assistenten & 6 & 12 & 109 \\
onderwijsmedewerkers & 3 & 5 & 52 \\
assistenten-in-opleiding & 3 & 6 & 62 \\
totaal & 19 & 37 & 357 \\
\hline
\end{tabular}

Tabel 3.2

Aantallen deelnemende tutoren, onderwijsgroepen en studenten in het blok "Onrechtmatig gedrag"

\begin{tabular}{lccc} 
tutoren & $\mathbf{n}$ & $\begin{array}{c}\text { aantal onder- } \\
\text { wijsgroepen }\end{array}$ & $\begin{array}{c}\text { aantal } \\
\text { studenten }\end{array}$ \\
\hline stafleden & 4 & 8 & 102 \\
student-assistenten & 5 & 10 & 105 \\
onderwijsmedewerkers & 4 & 9 & 92 \\
assistenten-in-opleiding & 2 & 5 & 346 \\
totaal & 15 & 32 & 346
\end{tabular}




\section{Beschrijving van de gebruikte onderzoeksinstrumenten}

In deze paragraaf wordt kort beschreven welke onderzweksinstrumenten gebruikt zijn om de onderzoeksvragen te onderzoeken. Eerst komen de instrumenten aan de orde die gebruikt zijn ten behoeve van het onderzoek onder de studenten. Voorafgaande aan beide onderwijsblokken werd informatie verzameld over de kennis die de studenten hadden over de onderwerpen die in de blokken ter sprake zouden komen (de voorkennismeting). Tijdens de onderwijsperiode werd onderzocht hoeveel tijd de studenten besteedden aan zelfstudie en deelname aan het onderwijs (de studietijdmeting). Kort voor de afronding van ieder onderwijsblok werd informatie vergaard over het gedrag van de tutor tijdens de groepsbijeenkomsten (de tutorgedragmeting) en effecten daarvan op de studenten. In samenhang daarmee werd ook aan de studenten gevraagd een oordeel te geven over het genoten onderwijs, zowel via een schriftelijke enquête als via interviews (de programma-evaluatie). Tenslotte werden na afloop van iedere blokperiode de leerprestaties van de studenten gemeten (de kennistoets).

Zoals gezegd: de bespreking van de verschillende instrumenten zal kort zijn. Uitgebreide beschrijvingen zullen volgen in de hoofdstukken waar resultaten van de verschillende metingen gerapporteerd worden.

\section{Instrumentarium ten behoeve van de studenten}

\section{De voorkennismeting}

Voordat de beide onderwijsblokken begonnen, werd door de onderzoeker in samenspraak met de blokcoördinatoren van beide onderwijsblokken een toets samengesteld die de onderzoeker de gelegenheid gaf na te gaan over welke kennis de studenten beschikten aan de vooravond van de onderwijsblokken waarin het onderzoek plaats zou vinden. Deze meting werd verricht ten behoeve van een achteraf-controle op de vergelijkbaarheid van experimentele en controlegroep met betrekking tot dit kenmerk. De voorkennismeting vond plaats door middel van een toets bestaande uit juist-onjuist vragen. De toetsitems werden geschreven door de blokcoördinatoren van de desbetreffende blokken. Voor blok 1.3 werd een toets bestaande uit 24 items ontwikkeld, voor blok 1.4 bestond de voorkennismeting uit 26 items.

\section{Studietijdgegevens}

Voorafgaande aan de beide onderwijsperioden werd aan de studenten gevraagd mee te doen aan een tijdsbestedingsonderzoek. Deze informatie leek van belang omdat een van de te toetsen hypothesen veronderstelde dat studenten, begeleid door een student-tutor, wellicht de veronderstelde relatieve kennisachterstand van hun tutor zouden gaan compenseren door meer tijd te investeren in hun studie. De studietijd werd als volgt gemeten. Wekelijks 
werd aan alle studenten. geplaatst in de onderwijsgroepen begeleid door stafleden-tutoren of student-tutoren, een tijdschrijfformulier uitgereikt waarop ze dagelijks konden invullen hoeveel tijd zij besteed hadden aan zelfstudie ten behoeve van activiteiten voor de onderwijsgroep, aan het practicum en aan het college rechtsgeschiedenis, en hoeveel tijd zij besteedden aan het bijwonen van genoemde onderdelen. Wekelijks werden deze formulieren opgehaald en administratief verwerkt.

\section{De observatielijst 'tutorgedrag'}

In de laatste week van ieder onderwijsblok werd aan alle studenten, via een schriftelijke enquête, een oordeel gevraagd over het functioneren van hun tutoren. Deze informatie werd van belang geacht om na te kunnen gaan of student-tutoren, in de ogen van de studenten, op een andere wijze hun taak vervullen dan de staf-tutoren, zoals één van de veronderstellingen besproken in Hoofdstuk 1 luidde. De observatielijst die de studenten voorgelegd kregen bestond uit 46 vragen die betrekking hadden op verschillende gedragingen van de tutoren.

\section{Oordeel van de studenten over het onderwijs}

Gelijktijdig met de vragenlijst naar het tutorgedrag werd tevens aan alle studenten via een schriftelijke enquête een oordeel gevraagd over andere aspecten van het onderwijs dat zij in de desbetreffende blokperiode ontvangen hadden. Deze informatie werd van belang geacht om na te kunnen gaan of studenten in beide onderwijscondities een verschillend oordeel zouden vellen over het onderwijs dat zij ontvangen hadden. Deze vragenlijst bestond in totaal uit 35 vragen. Een aantal vragen betrof de kwaliteit van het onderwijsblok in het algemeen, alsmede de kwaliteit van het practicum en de colleges. Andere vragen hadden betrekking op het blokboek en het functioneren van de onderwijsgroep.

\section{Interviews}

Om een meer gedetailleerd inzicht te krijgen in bovengenoemde aspecten van het onderwijs werden tevens in de laatste drie weken van elke blokperiode interviews afgenomen. Uit alle onderwijsgroepen werden enkele studenten aselect uitgenodigd deel te nemen. Uiteindelijk werden van iedere onderwijsgroep twee studenten geinterviewd. Aan de hand van enkele open vragen konden studenten over hun ervaringen met het onderwijs vertellen.

\section{Kennistoets}

$\mathrm{Na}$ afloop van ieder blok werd aan de deelnemers, onder examencondities, een kennistoets voorgelegd. Deze toets werd gebruikt om na te gaan of er verschillen waren opgetreden tussen studenten begeleid door tutoren in een van beide condities. De kennistoets van elk van beide blokken bestond uit 7 
essayvragen. Vijf van deze vragen hadden betrekking op de onderwerpen die in het blokboek aangeboden en in de onderwijsgroepen besproken waren, twee vragen hadden betrekking op het college rechtsgeschiedenis en de literatuur die daarvoor bestudeerd moest worden.

\section{Instrumentarium voor de tutoren}

Ook van de tutoren in beide blokken werden nadere gegevens verzameld. Uitgaande van de veronderstelling dat de mate van vakinhoudelijke deskundigheid van de tutor invloed heeft op de leerprestaties van studenten leek het zinvol hieraan aandacht te besteden. Op tweeërlei wijze werd informatie verzameld over de deskundigheid van de tutoren met betrekking tot de onderwerpen die in dit blok aan de orde zouden komen. Nagegaan werd de mate waarin de tutoren vakinhoudelijk deskundig waren, respectievelijk zich vakinhoudelijk deskundig voelden. Om na te gaan hoe deskundig de tutoren waren, kregen zij voor de aanvang van elk blok een kennistoets voorgelegd. Om meer inzicht te krijgen in hun subjectieve oordeel over hun kennis met betrekking tot de blokboekonderwerpen ontvingen alle tutoren tijdens het blok een vragenlijst.

\section{Meting van de kennis van tutoren}

Voordat het blok begon werd door de onderzoeker in samenspraak met de blokcoördinator een ruim aantal toetsitems geselecteerd uit een itembank met betrekking tot de vakgebieden die in de respectievelijke blokken aan de orde komen. Hieruit werd door de onderzoeker een toets samengesteld om na te gaan over welke vakinhoudelijke kennis de tutoren beschikten. Deze toets bestond uit meer en moeilijker toetsitems dan de voorkennismeting van de studenten om meer genuanceerd te kunnen differentiëren tussen de tutoren. Voorafgaande aan iedere onderwijsperiode werd deze toets aan alle tutoren voorgelegd. Elk van beide toetsen bestond uit 40 juist-onjuist vragen die door de tutor thuis kon worden ingevuld en daags na de uitreiking moest worden ingeleverd.

\section{Vragenlijst oordeel eigen deskundigheid}

Het tweede instrument waarmee de vakinhoudelijke deskundigheid van de tutoren werd nagegaan betrof een korte vragenlijst. In de achtste en laatste week van iedere blokperiode ontvingen de tutoren deze enquête waarin hen verzocht werd aan te geven hoeveel onderwijservaring zij hadden en hoe vaak zij als tutor waren opgetreden in het desbetreffende blok en in het algemeen. Daarnaast konden de tutoren vermelden hoe deskundig zij zich achtten met betrekking tot de verschillende onderdelen van het blok. 


\section{Samenvatting}

In dit hoofdstuk is de opzet van het onderzoek van deze studie naar de leerprestaties van studenten begeleid door student-tutoren of staflid-tutoren beschreven. Beschreven werd op welke wijze de studenten- en de tutorengroepen samengesteld werden. Daarna werden de instrumenten globaal beschreven die in de verschillende hoofdstukken van deze studie gebruikt worden. In het volgende hoofdstuk zal verslag gedaan worden van een eerste analyse van de leerprestaties van studenten onder de twee condities van het veldexperiment. 


\title{
Verschillen in leerprestaties in docentge- leide en studentgeleide onderwijsgroepen
}

\author{
Resultaten van de bloktoetsmetingen
}

\section{Inleiding}

In dit hoofdstuk zullen twee veldexperimenten beschreven worden waarbij de prestaties van studenten begeleid door student-tutoren vergeleken werden met de leerprestaties van studenten begeleid door staf-tutoren. Zoals beargumenteerd in Hoofdstuk 2 werd verwacht dat de studenten begeleid door de staftutoren betere leerprestaties zouden leveren. Stafleden lijken immers beter dan student-assistenten in staat studenten vakinhoudelijk te begeleiden. In het algemeen zullen zij immers over meer deskundigheid beschikken met betrekking tot de onderwerpen die in het blok aan de orde komen dan de studentassistenten die ongeveer drie à vier jaar onderwijs in de juridische vakken genoten hebben. De stafleden zullen waarschijnlijk niet alleen over meer feitelijke informatie beschikken maar ook een beter overzicht hebben over de leerstof. Daardoor zullen ze in het algemeen beter in staat zijn de studenten te ondersteunen in het begrijpen van die leerstofonderdelen die wezenlijk zijn voor een goed begrip van de thematiek van het blok. Daarnaast zullen ze ook beter en eerder in staat zijn de belangrijkheid respectievelijk onbelangrijkheid van het besprokene dat ter tafel komt in de onderwijsgroep in te schatten, waardoor verondersteld mag worden dat ze de studenten in hun onderwijsgroep sneller en gerichter op het juiste spoor kunnen zetten.

\section{Het meten van leerprestaties met behulp van essayvragen}

Studieprestaties werden in dit onderzoek gemeten door middel van essayvragen. Deze wijze van meten van de leerprestaties van studenten berustte op een beslissing van de faculteit. Vanaf de start wilde het docentencorps toetsen 
op kennisverwerving, inzicht en het vermogen om de leerstof te kunnen toepassen en gebruiken. Naast de aan de Rijksuniversiteit Limburg gebruikelijke voortgangstoets werd aldus een bloktoets met essayvragen geïntroduceerd.

"Er ontstaat ... een eigen plaats voor de bloktoets: geen kennistoets maar een toets die wil meten of de studenten (de kern van) de stof begrepen hebben en die kunnen toepassen en gebruiken" (Nota Toetsing, Faculteitsbestuur FdR, 1987 p. 4).

Voor bijna alle eerder gerapporteerde onderzoeken naar studentgeleid onderwijs gold dat de prestatiemeting plaats vond via meerkeuzevragen, juistonjuist vragen of een combinatie van meerkeuzevragen en essayvragen. Uitzonderingen waren de onderzoeken van Clement (1971) en Moust et al. (1989). In Clements' onderzoek bleef echter de precieze aard van de vragen onduidelijk. Uit de rapportage van zijn onderzoek bleek dat hij de studenten herhaaldelijk dezelfde essayvragen voorlegde. Ook in de onderzoeken waarbij gebruik gemaakt werd van een combinatie van meerkeuzevragen en essayvragen (bijvoorbeeld Hovey et al., 1963; Ten Cate, 1986) werd zelden informatie verstrekt over de aard van de essayvragen. Nergens werd bovendien beschreven op welke wijze de antwoorden op de essayvragen beoordeeld werden. In zijn onderzoek naar studentgeleid onderwijs gaf Ten Cate (1986) wel een voorbeeld van het soort essayvragen dat aan de studenten voorgelegd werd. Kenmerkend voor dat voorbeeld, betrekking hebbend op epidemiologische en statistische leerstof, was dat de studenten deze essayvraag met één, cijfermatig, antwoord konden beantwoorden, zonder dat een nadere motivering van het antwoord verlangd werd.

Uit de literatuur over toetsvormen blijkt dat auteurs nogal ambivalent tegenover toetsing door middel van essayvragen staan. Enerzijds wordt erkend dat toetsing met behulp van essayvragen een eigen plaats inneemt binnen het scala van toetsvormen, anderzijds kleven er ook veel psychometrische bezwaren aan. Op grond daarvan wordt toetsing van leerprestaties met behulp van essayvragen slechts onder zeer specifieke voorwaarden aanbevolen (Gronlund, 1976, 1982; Mehrens \& Lehman, 1975). Essayvragen worden vooral beschreven als nuttige toetsinstrumenten voor het meten van die leerprestaties die niet of moeilijk gemeten kunnen worden door middel van objectieve tests, zoals tests bestaande uit meerkeuze-, juist-onjuist of aanvulvragen. Gronlund formuleert het specifieke van essayvragen als volgt:

"Essay questions should be used, primarily, for the measurement of those learning outcomes that cannot be measured by objective test items. ... Learning outcomes concerned with the abilities to select, organize, integrate, relate, and evaluate ideas, require the freedom of response and the originality provided for by essay questions" (Gronlund, 1976, p. 233). 
Essayvragen toetsen, in tegenstelling tot objectieve toetsprocedures, het vermogen van de student om zelfstandig informatie te produceren.

De denkactiviteiten van de studenten bij de beantwoording van essayvragen die evaluatie, synthese en toepassing van kennis van de student vereisen, zouden meer gericht zijn op "complex leaming outcomes" (Gronlund, 1976) of "higher mental processes" (Mehrens \& Lehman, 1975). De essayvraag biedt de student enige vrijheid in de wijze van formuleren, maar ook in de keuze van wat in het antwoord vermeld wordt. Daarbij doet de essayvraag meer een beroep op het vermogen van de student zijn kennis over een bepaald onderwerp actief te operationaliseren. De student moet er daarbij blijk van geven dat hij in staat is de kennis die hij tijdens zijn studie verworven heeft actief terug te roepen en toe te passen. Het grootste verschil tussen essayvragen en de objectieve toetsvragen bestaat hierin dat essayvragen een beroep doen op het vermogen van de student zélf het antwoord te construeren terwijl objectieve vragen een beroep doen op het herkennen, identificeren of reconstrueren van het juiste antwoord uit meerdere vooraf vastgelegde antwoorden. Bij objectieve vraagtypen moet de student het antwoord selecteren uit een aantal aangeboden keuzes.

Hoewel essayvragen in de literatuur over toetsvormen dus van onmiskenbaar belang worden geacht voor met name het meten van de hogere cognitieve vaardigheden, kleven er, zoals gezegd, bezwaren aan. De eerste betreft de beoordeling van antwoorden op essayvragen. Met name de meetbetrouwbaarheid van de beoordeling is een kwetsbaar punt. Meetbetrouwbaarheid wil in het geval van essayvragen zeggen dat de verschillende beoordelaars op hétzelfde tijdstip, of een beoordelaar op verschillende tijdstippen, tot éénzelfde oordeel komen. Wanneer echter een beoordelaar eenzelfde essayvraag op verschillende tijdstippen nakijkt, blijkt dat de beoordeling van het antwoord vrij ver uiteen kan lopen. Datzelfde geldt voor de interbeoordelaarsbetrouwbaarheid, de overeenstemming in waardering die meerdere beoordelaars toekennen aan hetzelfde antwoord. Uit een overzicht dat Mellenbergh (1971) geeft van onderzoeken naar de beoordeling van open vragen blijkt dat de overeenstemming tussen beoordelaars over het algemeen sterk uiteen loopt. De intercorrelaties variëren afhankelijk van het vak, niveau van onderwijs, aantal beoordelaars en het aantal beoordeelde vragen van 0,44 tot 0,96 . Ook Coffman (1971) rapporteert op grond van literatuurstudie waarden variërend van 0,35 tot 0,98 afhankelijk van de context waarin het onderzoek had plaatsgevonden, de wijze waarop de vragen geformuleerd waren en het aantal docenten dat bij het beoordelen van de antwoorden betrokken was. De Groot (1961) noemt enkele redenen waarom verschillende beoordelaars (of zelfs eenzelfde beoordelaar) kunnen verschillen in de beoordeling van hetzelfde antwoord. Zo kunnen beoordelaars een verschillende opvatting over de beoordelingstaak hebben (het signifisch effect) en kunnen persoonlijke eigenschappen en normen van een beoordelaar een rol spelen bij de kriteria die hij 
hanteert voor het toekennen van hoge of lage cijfers. Ook kunnen andere kenmerken van het te beoordelen antwoord dan het kenmerk waamaar het antwoord beoordeeld moet worden invloed op de beoordeling hebben (haloeffect) en kunnen voorafgaande beoordelingen doorwerken op volgende beoordelingen (sequentie-effect).

Om de beoordelaarsbetrouwbaarheid van essayvragen te verhogen worden in de literatuur over toetsing verschillende methoden aangereikt. Zo onderscheidt Coffman (1971) de "rating method" en de "global method". Bij de eerste methode wordt door de vragensteller het mogelijke antwoord opgedeeld in verschillende specifieke subcategorieën die elk een bepaald aantal punten toegekend krijgen. De beoordelaar moet dan nagaan welke onderdelen in het antwoord van de student terug te vinden zijn en aan de hand van de puntenschaal tot een waardering komen. Bij de global method worden door de beoordelaars eerst een aantal antwoorden "gescanned", op basis waarvan zij tot een globale aanduiding van een bepaald standaardantwoord komen en tot een nadere specificering van een waardering voor bepaalde antwoordcategorieën. Bij deze methode wordt de beoordelaars binnen bepaalde grenzen echter een zekere vrijheid gegund hun persoonlijk oordeel mee te wegen in het bepalen van het cijfer.

Ecn tweede probleem dat bij het beoordelen van leerprestaties door middel van essayvragen veelvuldig optreedt is het probleem van de beperkte dekking. Het aantal vragen dat de studenten wordt aangeboden bestrijkt veelal niet alle leerstof die voor de toets bestudeerd moet worden. Binnen de beperkte tijd die een toets duurt, kunnen de studenten immers slechts een beperkt aantal vragen beantwoorden. Dit aantal ligt aanzienlijk lager dan het aantal vragen dat de studenten kunnen beantwoorden wanneer gebruik wordt gemaakt van objectieve toetsen. Deze beperkte dekking van het bestudeerde domein kan ertoe leiden dat de leerprestaties van studenten beoordeeld worden op een meting gebaseerd op een relatief beperkt aantal leerstofgebieden. Studenten die hun aandacht vooral gericht hebben op die gebieden waar de vragen over gesteld worden zullen een hoge score krijgen, terwijl studenten die toevallig meer aandacht hebben besteed aan andere onderwerpen een lagere score krijgen dan hun studieprestaties/-inspanningen rechtvaardigt (Ahmann \& Glock, 1971; Gronlund, 1982).

In het hier te bespreken onderzoek zijn twee procedures gebruikt om de leerprestaties van de studenten te beoordelen. Eerst werden de antwoorden van de studenten op de bloktoetsvragen door een aantal docenten gescoord met behulp van de in de juridische faculteit gangbare beoordelingsmethode. Daarnaast werd door onafhankelijke beoordelaars een aselecte steekproef van de bloktoetsantwoorden op een meer gedetailleerd niveau nogmaals beoordeeld. Voor deze beoordeling van de leerprestaties werd de methode van propositie-analyse (Schmidt, 1982) benut. Propositie-analyse is een methode die 
de onderzoeker in staat stelt antwoorden op essayvragen meer gedetailleerd en veelal ook meer betrouwbaar te scoren.

In dit hoofdstuk zal eerst aandacht besteed worden aan de leerprestaties van staf- versus studentbegeleide studenten in de onderwijsblokken "Rechtshandeling" en "Onrechtmatig gedrag". Eerst wordt de wijze waarop de leerprestaties van de studenten onderzocht is beschreven en vervolgens wordt weergegeven in hoeverre verschillen in leerprestaties geconstateerd konden worden tussen de verschillende condities van het experiment. Daarna wordt de procedure van toetsing via de propositie-analyse beschreven. Vervolgens worden de onderzoeksresultaten die deze alternatieve vorm van beoordeling oplevert, besproken. Tenslotte worden de bevindingen van dit deel van het onderzoek kort samengevat.

\section{Experiment 1: Leerprestaties van de studenten in het blok "Rechtshandeling"}

\section{Methode}

\section{Proefpersonen}

Onderzocht werden de leerprestaties van eerstejaarsstudenten rechten die deelnamen aan het blok "Rechtshandeling" tijdens het studiejaar 1988/1989 die begeleid werden door hetzij student-tutoren, hetzij stafleden-tutoren.

Aan het onderzoek namen 230 studenten deel. De groep begeleid door 7 stafleden-tutoren bestond uit 125 studenten, de groep begeleid door 6 studenttutoren omvatte 105 studenten.

\section{Materiaal}

Voorafgaande aan het onderwijsblok kregen alle studenten een toets voorgelegd, waarin hun voorkennis met betrekking tot de onderwerpen die in de blokken "Rechtshandeling" (blok 1.3) en "Onrechtmatig gedrag" (blok 1.4) aan de orde zouden komen, gemeten werd. De voorkennismeting van het blok "Rechtshandeling" bestond uit 24 vragen van het juist-onjuist type. Een voorbeeld van enkele toetsitems uit beiden blokken van deze voorkennismeting staat opgenomen in Tabel 4.1. De alpha-betrouwbaarheid van de voorkennismeting "Rechtshandeling" was 0,58.

De eindtoets die de studenten voorgelegd kregen, bestond uit zeven essayvragen. Vijf vragen hadden betrekking op de onderwerpen die via het blokboek aan de orde gesteld waren. Een voorbeeld van een vraag staat opgenomen in Tabel 4.2. Twee vragen betroffen de leerstof die op het college "Rechtsgeschiedenis" aan de orde was gesteld en een daarvoor te bestuderen studieboek. Dit college werd gedurende 6 weken, 2 uur per week, gegeven. 
- Ontbinding van een wederkerige overeenkomst is slechts mogelijk via de rechter. (blok 1.3)

- A. ziet bij een uitdragerij een schilderij waarvan hij denkt dat het een tot nu toe onbekende Vermeer is. A betaalt voor het schilderij een bedrag van fl. 2.000 .00 zonder de verkoper in te lichten over zijn ontdekking. Het schilderij blijkt naderhand een vrij recente en slechte imitatie te zijn, en nog geen fl. 2.000,00 waard.

A. kan zich met succes op dwaling beroepen. (blok 1.3)

- De voorzienbaarheid van de schade speelt geen rol binnen de leer van de toerekening naar redelijkheid in het burgerlijk recht. (blok 1.4)

- A. geeft B. een stomp. B. valt en moet in het ziekenhuis behandeld worden. De ziekenauto die B. nais het ziekenhuis brengt, krijgt een ongeluk. Alle inzittenden overlijden. A wordt vervolgd terzake van doodslag van $B$.

In de conditio sine qua non-leer is er sprake van causaal verband tussen de handeling van $\mathrm{A}$ en de dood van $\mathrm{B}$. (blok 1.4)

Tabel 4.2

Voorbeeld bloktoetsvraag blok "Onrechtmatig gedrag", vraag 5

Remco van Dalen is als schilder in dienst van Jongen B.V. Reeds enkele weken is hij werkzaam in het huis van de familie Custers.

De woning moet zowel van binnen als van buiten grondig onder handen worden genomen. Gedurende deze opknapbeurt houdt het gezin Custers vakantie aan de Noordhollandse kust. Tijdens zijn schilderwerk ontdekt Remco dat mevrouw Custers een liefhebber is van zeldzaam glaswerk. Ze heeft een kostbare verzameling in enkele vitrines uitgestald in de woonkamer. Toevallig heeft Remco een neef die ook zeer geïnteresseerd is in oud glaswerk. Om deze neef een plezier te doen, stelt hij op een avond voor even een kijkje te gaan nemen in huize Custers. Dit voorstel valt uiteraard wel in de smaak en het tweetal gaat op pad. Remco heeft in verband met de schilderwerkzaamheden de sleutel van het huis, zodat ze zonder problemen naar binnen kunnen. Nadat ze de glasverzameling enige tijd hebben bewonderd, gebeurt het: Remco glijdt om onduidelijke redenen uit en valt met zijn volle gewicht tegen één van de vitrinekasten. De gevolgen laten zich raden. De kast met inhoud ligt in duizend stukken op de vloer.

a. Geef gemotiveerd aan of mevrouw Custers de schade kan verhalen op Remco van Dalen respectievelijk op Jongen B.V.

b. Geef gemotiveerd aan wie de schade uiteindelijk moet dragen. 


\section{Procedure}

De voorkennismeting werd gedaan om na te kunnen gaan of de randomisatieprocedure gelukt was en dus geen signiticante verschillen in voorkennis tussen beide groepen bestonden, die de betrouwbaarheid en validiteit van de uitkomsten zouden kunnen aantasten. Deze toets werd afgenomen op vrijwillige basis. Op grond van practische overwegingen werd besloten de voorkennismeting te laten bestaan uit een meerkeuzetoets.

De vragen over de onderwerpen die tijdens de bloktoets aan de orde zouden kunnen komen, werden in de vierde week van het blok door de blokcoördinator en enkele stafleden die hadden meegewerkt aan het samenstellen van het blokboek, in onderling overleg geconstrueerd. Vervolgens werden deze vragen voorgelegd aan de onderwijscoördinator van het eerste studiejaar en de andere blokcoördinatoren van de overige eerstejaars onderwijsblokken. $\mathrm{Na}$ onderlinge discussie en wijziging stelde deze commissie de uiteindelijke vragen voor de bloktoets vast.

De rechtshistorische bloktoetsvragen werden ontwikkeld door de docent die het desbetreffende college gaf. Ook deze vragen werden in het overleg van de jaarcoördinator van het eerste studiejaar en de blokcoördinatoren beoordeeld op geschiktheid.

De studenten kregen de toets, onder normale examencondities, direct aansluitend op de blokperiode voorgelegd. De studenten moesten, naar keuze, elk drie van de vijf vragen beantwoorden die op de onderwerpen van het blokboek betrekking hadden. Eveneens naar keuze moesten zij één van de twee rechtshistorische vragen beantwoorden.

Direct na de toets werden de antwoorden door stafleden, die nauw betrokken waren geweest bij de uitvoering van het onderwijs in dit blok en die over specifieke deskundigheid beschikten met betrekking tot het onderwerp dat getoetst werd, beoordeeld. Afhankelijk van het aantal studenten dat voor een

Beoordelingssysteem bloktoetsantwoorden, blok "Rechtshandeling"

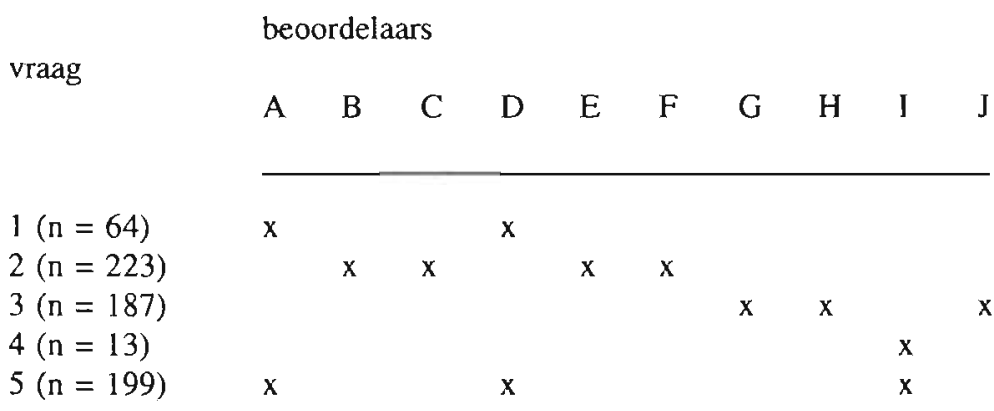


bepaalde vraag gekozen had, werd bepaald hoeveel docenten de desbetreffende vraag zouden nakijken (zie Figuur 4.1). Ieder antwoord werd door één beoordelaar beoordeeld. De beoordelingsprocedure per vraag verliep als volgt. ledere beoordelaar beschikte over een globaal antwoordmodel en scoringsvoorschrift dat voorafgaande aan de toets door de blokcoördinator opgesteld was. In het antwoordmodel stond aangegeven wat het goede antwoord is of wat de essentie van het goede antwoord is. Het scoringsvoorschrift gaf aan hoeveel punten maximaal voor een (deel)antwoord toegekend konden worden (zie Tabel 4.3 voor een voorbeeld). Iedere beoordelaar bekeek de hem of haar toegewezen antwoorden na aan de hand van dit antwoordmodel en scoringsvoorschrift. Ieder antwoord van de student was uitsluitend voorzien van het examennummer van de desbetreffende student.

Vervolgens werd door de beoordelaar het cijfer op het antwoord van de student doorgegeven aan het Buro Onderwijs van de faculteit. Daar werden alle cijfers op de vragen die de student beantwoord had gesommeerd en gedeeld door het aantal te beantwoorden vragen, waarna het bloktoetscijfer werd vastgesteld.

Tabel 4.3

Globaal antwoordmodel en scoringsvoorschrift behorende bij vraag 5 blok "Onrechtmatig gedrag"

Vraagdeel a.

Wat betreft de aansprakelijkheid van Remco (de werknemer): 4 punten.

Hiervoor motten alle elementen van de onrechtmatige daad worden nagelopen:

- er is sprake van een onrechtmatige handelen van Remco, te weten inbreuk op het eigendomsrecht van mevr. Custers;

- de relativiteit is bij dit onrechtsmatigheidscriterium geen probleem;

- de daad kan hem worden toegerekend. Er is geen sprake van schuld (onoplettendheid en daarmee verwijtbaarheid);

- er is schade;

- de causaliteit levert geen problemen op. Er is conditio-sine-qua-non verband aanwezig. Bij toepassing van de leer van de toerekening naar redelijkheid kan de schade zonder meer dan Remco worden toegerekend.

Conclusie: Remco is aansprakelijk jegens mevrouw Custers voor de schade.

Wat betreft de aansprakelijkheid van Jongen B.V. (de werkgever): 4 punten.

etc. 


\section{Resultaten}

In Tabel 4.4 wordt het gemiddeld percentage goed-fout score en de standaarddeviatie van de studenten begeleid door student-tutoren en staf-tutoren op de voorkennismeting weergegeven.

Verschillen tussen gemiddelden die in Tabel 4.4 zijn weergegeven, werden getoetst door middel van variantieanalyse (ANOVA). De resultaten daarvan zijn: $F(1,205)=0,86, \mathrm{p}<0,35$. Dat betekent dus dat er tussen beide groepen geen significant verschil in voorkennis met betrekking tot het te bestuderen onderwerp geconstateerd kon worden. Eventuele verschillen in gemiddelde studieprestaties kunnen dus niet herleid worden tot verschillen in kennis die al voorafgaande aan het blok bestonden. Opvallend is overigens de aanzienlijke variatie in voorkennis binnen beide groepen.

Tabel 4.4

Gemiddelde percentages goed min fout (met standaarddeviaties) op de voorkennismering voor het blok "Rechtshandeling"

\begin{tabular}{lccc}
$\begin{array}{l}\text { Experimentele } \\
\text { conditie }\end{array}$ & $\mathrm{N}$ & $\begin{array}{c}\text { Gemiddeld percentage } \\
\text { goed-fout score }\end{array}$ & Standaarddeviatie \\
\hline
\end{tabular}

Groep begeleid door

staf-tutoren

$\begin{array}{lll}114 & 9,6 & 15,0\end{array}$

student-tutoren

93

11,6

15,0

Totaal

207

10,5

15,0

In Tabel 4.5 is de gemiddelde totaalscore weergegeven. Deze score is gebaseerd op het gemiddelde van de score van de studenten op drie van de vijf vragen die zij voor het onderwijs met betrekking tot het blokboek moesten beantwoorden. Dus exclusief het cijfer verkregen voor de rechtshistorische vraag.

Verschillen tussen gemiddelden die in Tabel 4.5 zijn weergegeven, werden getoetst door middel van variantieanalyse (ANOVA). De resultaten daarvan zijn: $F(1,228)=0,002, \mathrm{p}<0,97$. Dat betekent dus dat de leerprestaties van de studenten begeleid door student-tutoren niet significant verschillen van de leerprestaties van de studenten begeleid door staf-tutoren. Verschillen konden ook niet geconstateerd worden op de afzonderlijke toetsvragen, zoals uit Tabel 4.6 is op te maken. 
Gemiddelden en standaarddeviaties voor de totaalscores op het blok "Rechtshandeling"

$\begin{array}{llll}\begin{array}{l}\text { Experimentele } \\ \text { conditie }\end{array} & \mathrm{N} & \text { Gemiddelde } & \text { Standaarddeviatie }\end{array}$

Groep begeleid door

staf-tutoren

125

5,6

1,6

Groep begeleid door

student-tutoren

105

5,5

1,5

Totaal

230

5,5

1,6

Tabel 4.6

Gemiddelden en standaarddeviaties per vraag voor de bloktoets op het blok "Rechtshandeling"

\begin{tabular}{|c|c|c|c|c|c|c|c|}
\hline $\mathrm{Vr}$ & $\begin{array}{l}\text { Groep begeleid } \\
\text { door }\end{array}$ & $\mathrm{N}$ & Gem & SD & $\begin{array}{l}\text { F-geob- } \\
\text { serveerd }\end{array}$ & $d f$ & $\begin{array}{l}\text { p-geob- } \\
\text { serveerd }\end{array}$ \\
\hline 1 & $\begin{array}{l}\text { staf-tutoren } \\
\text { student-tutoren }\end{array}$ & $\begin{array}{l}38 \\
26\end{array}$ & $\begin{array}{l}5,2 \\
5,2\end{array}$ & $\begin{array}{l}2,0 \\
1,5\end{array}$ & 0,00 & 62 & n.s. \\
\hline 2 & $\begin{array}{l}\text { staf-tutoren } \\
\text { student-tutoren }\end{array}$ & $\begin{array}{l}120 \\
103\end{array}$ & $\begin{array}{l}4,9 \\
5,1\end{array}$ & $\begin{array}{l}2,1 \\
2,1\end{array}$ & 0,36 & 221 & n.s. \\
\hline 3 & $\begin{array}{l}\text { staf-tutoren } \\
\text { student-tutoren }\end{array}$ & $\begin{array}{r}104 \\
83\end{array}$ & $\begin{array}{l}5,1 \\
5,0\end{array}$ & $\begin{array}{l}2,0 \\
2,0\end{array}$ & 0,21 & 185 & n.s. \\
\hline 4 & $\begin{array}{l}\text { staf-tutoren } \\
\text { student-tutoren }\end{array}$ & $\begin{array}{l}8 \\
5\end{array}$ & $\begin{array}{l}5,3 \\
6,1\end{array}$ & $\begin{array}{l}2,1 \\
1,3\end{array}$ & 0,56 & 11 & n.s. \\
\hline 5 & $\begin{array}{l}\text { staf-tutoren } \\
\text { student-tutoren }\end{array}$ & $\begin{array}{r}103 \\
96\end{array}$ & $\begin{array}{l}6,6 \\
6,4\end{array}$ & $\begin{array}{l}2,2 \\
2,1\end{array}$ & 0,22 & 197 & n.s. \\
\hline
\end{tabular}

In een enkel geval, bijvoorbeeld vraag 4, scoren de studenten begeleid door de student-assistenten gemiddeld wel beduidend hoger, maar ook hier is er geen sprake van significante verschillen. Uit bovenstaande gegevens mag geconcludeerd worden dat de studenten begeleid door stafleden hiervan geen voordelen ondervinden met betrekking tot hun leerprestaties. 
Met behulp van de generaliseerbaarheidstheorie (Cronbach, Gleser, Nanda \& Rajaratnam, 1972) is de betrouwbaarheid van de toetsen onderzocht. De volgende procedure werd gevolgd. Omdat de studenten konden kiezen welke vragen zij wilden beantwoorden, werden de studenten genest binnen de vragen. Hierdoor ontstaat een één facet, genest design ( $i$ : p). De betrouwbaarheid (gemeten middels een generaliseerbaarheidscoëfficiënt) van de toets voor het blok "Rechtshandeling" is 0,49 . Deze coëfficiënt is matig. Verhoging van het aantal vragen lijkt derhalve wenselijk. Bijlage 4.1 geeft een overzicht van de verschillende variantiecomponenten en de verschillende generaliseerbaarheidscoëfficiënten wanneer het aantal vragen in de bloktoets wordt verhoogd. Uit de tabel kan afgeleid worden dat er minimaal tien vragen aan de studenten moeten worden voorgelegd wil er sprake zijn van een redelijke betrouwbaarheid van de toets.

\section{Experiment 2: Leerprestaties van de studenten in het blok "Onrechtmatig gedrag"}

Net als in experiment 1 werden ook hier de leerprestaties van eerstejaars studenten rechten onderzocht, ditmaal ten aanzien van het blok "Onrechtmatig gedrag" tijdens het studiejaar 1988/1989.

\section{Methode}

\section{Proefpersonen}

Aan het onderzoek namen 172 studenten deel. De groep begeleid door vijf stafleden-tutoren bestond uit 82 studenten, de groep begeleid door vijf student-tutoren omvatte 95 studenten.

\section{Materiaal en procedure}

Zoals reeds eerder vermeld werd tijdens de tweede onderwijsperiode aan alle studenten een toets voorgelegd om hun voorkennis te meten met betrekking tot de onderwerpen die in het blok "Onrechtmatig gedrag" aan de orde zouden komen. Deze toets werd afgenomen om eventuele verschillen in voorkennis na te kunnen gaan tussen studenten begeleid door staf-tutoren of studenttutoren. Deze toets bestond uit 26 vragen van het juist-onjuist type. De alphabetrouwbaarheid van deze toets was 0,64 .

Ook de toets behorend bij dit blok bestond uit zeven essay-vragen: vijf vragen over de leerstof behandeld via het blokboek en twee vragen die betrekking hadden op het college "Rechtsgeschiedenis" dat wekelijks twee uur per week parallel aan het blok gegeven werd. De procedure voor het ontwikkelen van en beoordelen van de bloktoetsvragen verliep op dezelfde wijze als de procedure beschreven in Experiment 1. 
Direct volgend op het einde van de blokperiode kregen de studenten de toets onder normale examencondities voorgelegd. Ook nu moesten de studenten, nalar keuze, drie van de vijf vragen over de leerstof van het blokboek beantwoorden en een rechtshistorische vraag. De rechtshistorische vraag wordt ook hier verder buiten beschouwing gelaten.

Direct na de toets werden de antwoorden door een aantal stafleden, die nauw betrokken waren geweest bij de uitvoering van het onderwijs in dit blok, beoordeeld. De antwoorden werden naar ratio verdeeld over de vakinhoudelijk deskundige tutoren. Ieder antwoord, uitsluitend voorzien van het examennummer van de desbetreffende student werd door een beoordelaar nagekeken. Deze docent had daarbij de beschikking over een antwoordmodel en scoringsvoorschrift.

\section{Resultaten}

In Tabel 4.7 zijn de gemiddelde percentages goed-min fout scores van de resultaten van de voorkennismeting vermeld.

Tabel 4.7

Gemiddelde percentages goed min fout (met standaarddeviaties) op de voorkennismeting voor het blok "Onrechtmatig gedrag"

\begin{tabular}{|c|c|c|c|}
\hline $\begin{array}{l}\text { Experimentele } \\
\text { conditie }\end{array}$ & $\mathrm{N}$ & $\begin{array}{l}\text { Gemiddeld percentage } \\
\text { goed-fout score }\end{array}$ & Standaarddeviatie \\
\hline
\end{tabular}

Groep begeleid door

staf-tutoren

19,9

Groep begeleid door student-tutoren

Totaal

164

18,9

13,7

Verschillen tussen gemiddelden die in Tabel 4.7 zijn weergegeven werden getoetst door middel van variantieanalyse (ANOVA). De resultaten daarvan zijn: $F(1,162)=0,79, \mathrm{p}<0,38$. Dat betekent wederom dat er geen significant verschil in voorkennis geconstateerd kon worden tussen de groep studenten begeleid door student-tutoren vergeleken met de groep studenten begeleid door de stafleden-tutoren.

In Tabel 4.8 is de gemiddelde totaalscore van de bloktoetsresultaten weergegeven. De score is gebaseerd op het gemiddelde van de score van de studenten op drie van de vijf vragen die zij beantwoorden moesten. 


\section{Tabel 4.8}

Gemiddelden en standaarddeviaties voor de totaalscores op het blok "Onrechtmatig gedrag"

\begin{tabular}{llll}
$\begin{array}{l}\text { Experimentele } \\
\text { conditie }\end{array}$ & $\mathrm{N}$ & Gemiddelde & Standaarddeviatie \\
\hline
\end{tabular}

Groep begeleid door staf-tutoren

Groep begeleid door student-tutoren

In Tabel 4.8 zijn de verschillen tussen gemiddelden weergegeven. Deze werden getoetst door middel van variantieanalyse (ANOVA). De resultaten daarvan zijn: $F(1,175)=1,42, \mathrm{p}<0,23$. Dat betekent dus dat de leerprestaties van de studenten begeleid door student-tutoren niet significant verschillen van de leerprestaties van de studenten begeleid door staf-tutoren. Verschillen konden ook niet geconstateerd worden op de afzonderlijke toetsvragen, zoals uit Tabel 4.9 is op te maken.

Ook op het niveau van de afzonderlijke vragen kan geconstateerd worden dat de verschillen in leerprestaties tussen de studenten begeleid door studenttutoren en studenten begeleid door stafleden-tutoren, niet significant zijn. Wel opvallend is dat in dit blok studenten begeleid door stafleden op alle vragen gemiddeld iets hoger scoren dan de studenten begeleid door de student-assistenten.

Met behulp van de generaliseerbaarheidstheorie (Cronbach, Gleser, Nanda \& Rajaratnam, 1972) is weer de betrouwbaarheid van de toets onderzocht. Hierbij werd dezelfde procedure gevolgd als reeds beschreven is bij het blok "Rechtshandeling". De betrouwbaarheid (gemeten middels een generaliseerbaarheidscoëfficiënt van de toets voor het blok "Onrechtmatig gedrag" is 0,69 . Deze coëfficiënt is redelijk. Verhoging van het aantal vragen lijkt niettemin wenselijk. Bijlage 4.1 geeft een overzicht van de verschillende variantiecomponenten en de verschillende generaliseerbaarheidscoëfficiënten wanneer het aantal vragen in de bloktoets wordt verhoogd. Uit de tabel kan afgeleid worden dat er minimaal tien vragen aan de studenten moet worden voorgelegd wil er sprake zijn van een redelijke betrouwbaarheid van de toets. 
Tabel 4.9

Gemiddelden en standaarddeviaties per vraag voor de bloktoets op het blok "Onrechtmatig gedrag"

\begin{tabular}{|c|c|c|c|c|c|c|c|}
\hline $\mathrm{Vr}_{\mathrm{r}}$ & $\begin{array}{l}\text { Groep begeleid } \\
\text { door }\end{array}$ & $\mathrm{N}$ & Gem. & SD & $\begin{array}{l}\text { F-geob- } \\
\text { serveerd }\end{array}$ & $\mathrm{df}$ & $\begin{array}{l}\text { p-geob- } \\
\text { serveerd }\end{array}$ \\
\hline 1 & $\begin{array}{l}\text { staf-tutoren } \\
\text { student-tutoren }\end{array}$ & $\begin{array}{l}34 \\
33\end{array}$ & $\begin{array}{l}5,3 \\
5,2\end{array}$ & $\begin{array}{l}1,7 \\
1,8\end{array}$ & 0,19 & 65 & n.s. \\
\hline 2 & $\begin{array}{l}\text { staf-tutoren } \\
\text { student-tutoren }\end{array}$ & $\begin{array}{l}50 \\
50\end{array}$ & $\begin{array}{l}5,0 \\
4,5\end{array}$ & $\begin{array}{l}2,0 \\
2,1\end{array}$ & 1,20 & 98 & n.s. \\
\hline 3 & $\begin{array}{l}\text { staf-tutoren } \\
\text { student-tutoren }\end{array}$ & $\begin{array}{l}17 \\
30\end{array}$ & $\begin{array}{l}6,2 \\
5,7\end{array}$ & $\begin{array}{l}1,7 \\
1,6\end{array}$ & 1,17 & 45 & n.s. \\
\hline 4 & $\begin{array}{l}\text { staf-tutoren } \\
\text { student-tutoren }\end{array}$ & $\begin{array}{l}73 \\
85\end{array}$ & $\begin{array}{l}5,1 \\
4,7\end{array}$ & $\begin{array}{l}2,2 \\
2,0\end{array}$ & 1,62 & 156 & n.s. \\
\hline 5 & $\begin{array}{l}\text { staf-tutoren } \\
\text { student-tutoren }\end{array}$ & $\begin{array}{l}72 \\
86\end{array}$ & $\begin{array}{l}5,0 \\
4,9\end{array}$ & $\begin{array}{l}2,0 \\
1,7\end{array}$ & 0,14 & 156 & n.s. \\
\hline
\end{tabular}

\section{Discussie}

De vraag of de leerprestaties van studenten begeleid door staf-tutoren beter zijn dan de leerprestaties van studenten begeleid door student-tutoren lijkt op grond van de gegevens van dit onderzoek negatief beantwoord te moeten worden. Uit de gegevens van zowel veldexperiment 1 als veldexperiment 2 blijkt, dat de resultaten van de studenten begeleid door staf-tutoren vergeleken met student-tutoren zowel op het niveau van de afzonderlijke vragen als op het niveau van de totaalscore niet significant verschillen.

Het onderzoek kent echter een aantal beperkingen. Zo mochten de studenten zelf kiezen welke drie van de vijf vragen, gesteld op beide bloktoetsen, zij wilden beantwoorden. De mogelijkheid bestaat dat de studenten begeleid door bijvoorbeeld de staf-tutoren tot een andere selectie, bijvoorbeeld van moeilijker vragen, zijn gekomen dan de studenten begeleid door de studenttutoren. Analyse van de verdeling van de afzonderlijke vragen over de studenten laat echter zien dat van een specifieke voorkeur voor bepaalde vragen op beide blokken geen sprake is geweest.

Een tweede probleem dat opgeworpen zou kunnen worden betreft de samenstelling van de groep stafleden. In Hoofdstuk 1 is opgemerkt dat stafleden met een sterk verschillende vakinhoudelijke achtergrond als tutor ingezet worden in ieder blok. Hoewel er enige zelfselectie plaatsvindt op basis van 
voorkeuren van stafleden, kan niet iedereen in zijn of haar voorkeursblok geplaatst worden. In het blok "Rechtshandeling" traden een rechtshistoricus, een onderwijskundige en een rechtssocioloog op als tutor. Terecht zou men kunnen opperen dat deze niet-vakinhoudelijk deskundige tutoren een versluierend effect zouden kunnen hebben op de toetsprestaties van de groep studenten begeleid door de stafleden. Een nadere vergelijking van leerprestaties tussen studenten begeleid door student-assistenten en studenten begeleid door de vakinhoudelijke stafleden (b.v. privaat- en publiekrechtelijk geschoolde tutoren) laat echter zien dat dit niet het geval is. Zowel op het niveau van de afzonderlijke vragen als op het niveau van het totale eindcijfer (drie uit vijf) worden ook dan in het blok "Rechtshandeling" geen significante verschillen gevonden. Dit is echter wel het geval in het blok "Onrechtmatig gedrag". Geconstateerd kon al worden dat op het niveau van het totale eindcijfer en op het afzonderlijke vraagniveau (zie Tabellen 4.8 en 4.9) de leerprestaties van de studenten begeleid door de stafleden gemiddeld, maar niet statistisch significant, hoger liggen. Nadat één vakinhoudelijk niet-deskundige tutor verwijderd werd uit de subgroep staf-tutoren en de groepen vervolgens nogmaals vergeleken werden bleek er op één vraag, namelijk op vraag 4 , een significant verschil op te treden $(F(1,138)=4,36, \mathrm{p}<0,05)$. Ook op het niveau van de totaalscore is er dan bijna een significant verschil $(F(1,154)=3,28$, $\mathrm{p}<0,07)$. Dit resultaat zou kunnen betekenen dat wanneer alleen vakinhoudelijke tutoren in het onderwijs worden ingeschakeld, studenten begeleid door deze vakinhoudelijke tutoren betere leerprestaties behalen dan studenten begeleid door studenttutoren.

De derde beperking betreft het geringe aantal vragen dat aan de studenten gesteld werd. Niet helemaal uitgesloten kan worden dat studenten tijdens de bespreking van de taken uit het blokboek bepaalde accentverschillen in de bestudering van de leerstof gelegd hebben, die op de toetsing niet of juist wel aan de orde is geweest. Daardoor zou een van beide groeperingen tijdens de toetsing benadeeld respectievelijk bevoordeeld geweest kunnen zijn. Via het overleg dat wekelijks tussen de tutoren plaatsvond, werd nagegaan in hoeverre alle tutoren min-of-meer dezelfde taken behandelden. Dit bleek in het algemeen het geval te zijn. Een bepaalde selectie van de leerstof door een van beide onderzochte groepen in de richting van de toetsvragen lijkt daardoor onwaarschijnlijk.

Een vierde beperking met betrekking tot bovenstaande resultaten betreft de betrouwbaarheid van de beoordeling. Zoals beschreven werden de studentantwoorden beoordeeld door een beperkte groep van beoordelaars, namelijk die tutoren die vakinhoudelijk deskundig zijn op het terrein waarop de toetsvraag gesteld werd. De antwoorden werden anoniem, dit wil zeggen alleen voorzien van het examennummer van de betreffende student, en aselect verdeeld over de beoordelaars. Afhankelijk van het aantal antwoorden per vraag waren er een of meer beoordelaars. Ieder antwoord werd echter slechts door 
één beoordelaar gescoord. De beoordelaar beschikte over een globaal standaardantwoord en een scoringsvoorschrift. Door deze procedure werd geprobeerd de scoring van de antwoorden zoveel mogelijk te standaardiseren. Ondanks deze maatregelen is het niettemin niet onaannemelijk dat er vrij grote verschillen in interpretatie van de antwoorden tussen de beoordelaars zijn opgetreden.

Een laatste probleem zou kunnen zijn dat de gevolgde globale beoordelingsprocedure onvoldoende sensitief is om feitelijke verschillen aan het licht te brengen. Daarom werd een deel van de antwoorden van de studenten achteraf nogmaals zorgvuldig nagekeken en beide onderzoekspopulaties nogmaals met elkaar te vergeleken. De methode van propositie-analyse, die meer analytisch van aard is, vormde daarbij het uitgangspunt.

\section{Een nader onderzoek naar de bloktoetsantwoorden door middel van propositie-analyse}

\section{Inleiding}

In bovenstaande is al vermeld dat in de literatuur over toetsing de betrouwbaarheid van de scoring van essaytoetsen in het algemeen als laag beschouwd wordt. Ons onderzoek vormde daarop geen uitzondering. Daarom is er gezocht naar een andere methode die een meer betrouwbaar en ook specifieker beeld zou kunnen geven van de prestaties van de studenten. Gekozen werd voor de methode van propositie-analyse. Eerst wordt deze methode kort beschreven. Vervolgens worden de resultaten met betrekking tot de blokken "Rechtshandeling" en "Onrechtmatig gedrag" besproken.

\section{Bepaling van proposities in de antwoorden op de bloktoetsvragen}

De door de studenten geproduceerde antwoorden werden in proposities opgedeeld. Daarbij werd gebruik gemaakt van een procedure zoals beschreven in Schmidt (1982).

"Proposities zijn (meestal) onderwerp-gezegde-combinaties, die één bepaald idee uitdrukken. Men kan ze in teksten identificeren door voegwoorden (als "en", "of" en "want"), bijwoorden (als "wanneer" en "waardoor"), betrekkelijke voornaamwoorden, punten en puntkomma's te markeren. De tekstgedeelten tussen deze linguïstische markeringen kunnen als proposities beschouwd worden. Soms scheiden ook komma's of haakjes proposities van elkaar" (p. 40).

De volgende analyse van een antwoord op een toetsvraag van student $P$ 14 geeft een voorbeeld. De verticale strepen scheiden de proposities van elkaar. 
"Kan mevr. Goedhart het tafeltje met succes terugvorderen?// Art. 3.2.2. Een rechtshandeling vereist een op rechtsgevolg gerichte wil // die door een verklaring is geopenbaard.// In eerste instantie is aan deze voorwaarde voldaan// bij de totstandkoming van de overeenkomst // en is zij tot zover geldig.// Echter, mevr. Goedhart weet soms niet goed wat zij doet // tijdelijke geestelijke stoornis.// Art. 3.2.2.a is het artikel waarop zij een beroep kan doen om de koop ongedaan te maken.// $\mathrm{Zij}$ moet dan wel kunnen aantonen, // dat de handeling onder invloed van de stoornis is gedaan // en dat de stoornis een redelijke waardering van de betrokken belangen belette.// Kan zij beide factoren hard maken, // dan kan hierop de overeenkomst worden vernietigd"//......

De procedure voor het vaststellen en benoemen van de proposities verliep als volgt. De beoordelaar deelde eerst het antwoord op in proposities, volgens de kriteria zoals ze hierboven omschreven zijn. Daarna werd het aantal proposities geteld. Onvoltooide zinnen of pijlaanduidingen werden door de beoordelaar, voor zover mogelijk door correcte aanduidingen binnen de context van het geschrevene vervangen. Zo betekende een pijl veelal: "hieruit volgt" of parafrases hiervan. Vervolgens werd gekeken of proposities verwijderd moesten worden. Verwijderd werden die proposities die een herhaling van de vraagstelling, herhalingen van het antwoord of bladvulling waren. Zo was b.v. de zin "Kan mevr. Goedhart het tafeltje met succes terugvorderen?" uit bovenstaand voorbeeld een herhaling van datgene wat de docent in de oorspronkelijk toetsvraag al had gevraagd. Herhalingen van het antwoord werden verwijderd wanneer dergelijke herhalingen niets nieuws toevoegden. Bijvoorbeeld: een student (P 34) schreef "Jan schoot op zijn vrouw.// Hij deed dit doelgericht,// want hij nam zijn pistool,// ging...// en schoot vervolgens op haar.// De kogel ...//.../...// Hij deed dit doelgericht." Zowel het zinnetje "en schoot vervolgens op haar" als "hij deed dit doelgericht" werden verwijderd omdat de student dit al in een eerder deel van zijn antwoord schreef. Als bladvulling werden beschouwd zinnetjes als "Zo, nu gaan we eens kijken naar het volgende punt" (P 32) en "Dat was wat ik er van afweet" (P 39).

Vervolgens werd vastgesteld of de proposities die overblijven juridisch juist of onjuist waren. Deze beoordeling gebeurde op zuiver juridisch inhoudelijke criteria. Tenslotte werden de proposities, die als juist beoordeeld waren, onderverdeeld in descriptieve dan wel verklarende proposities. Dit onderscheid is belangrijk. Volgens Mayer (1985) geeft het aantal verklarende proposities in de antwoorden een goede indruk van de diepte van integratie van het onderwerp in de bestaande kennisstruktuur. Descriptief waren die proposities die feitelijk zijn. De propositie bevatte dan geen juridisch kwalificerend element, maar beschreef elementen uit de casus. Een voorbeeld van een descriptieve propositie uit bovenstaand stukje protocol was de zin "Echter, mevrouw Goedhart weet soms niet goed wat zij doet". Deze zin be- 
sclireef de geestelijke toestand waarin Mevr. Goedhart soms verkeerde. Dit gegeven was van belang om juridisch te kunnen kwalificeren of Mevr. Goedhart voor haar daden aansprakelijk kan worden gesteld of niet. Op het moment dat een propositie een juridisch kwalificerend element bevatte is de propositie niet meer descriptief maar verklarend, bijvoorbeeld de zin "Een rechtshandeling vereist een op een rechtsgevolg gerichte wil die door een verklaring is geopenbaard." bevatte twee explanatoire proposities, namelijk "Een rechtshandeling vereist een op een rechtsgevolg gerichte wil" en "die door een verklaring is geopenbaard".

Met behulp van deze regels werden de door de studenten geproduceerde antwoorden door twee beoordelaars gescoord. De interbeoordelaars-overeenstemming bij deze analyse was $81 \%$.

\section{Propositie-analyse op de bloktoetsantwoorden van het blok "Rechtshandeling"}

\section{Methode}

\section{Proefpersonen}

Voor elk van de vragen $1,2,3$, en 5 werden aselect 10 studenten gekozen uit de groep studenten begeleid door een staflid-tutor en 10 studenten uit de groep begeleid door een student-tutor. Vraag 4 is slechts door weinig studenten beantwoord. Voor deze vraag konden daarom slechts vijf studenten aselect worden uitgekozen die begeleid waren door een staflid-tutor en drie studenten begeleid door een student-tutor. Vermeden werd dat een student met meer dan één antwoord in de steekproef vertegenwoordigd zou zijn.

\section{Procedure}

De door de studenten beantwoorde toetsvragen werden in proposities opgedeeld conform de procedure beschreven in de vorige paragraaf.

\section{Resultaten}

In Tabel 4.10 zijn voor beide groepen gemiddelde aantallen geproduceerde proposities weergegeven. Het gaat daarbij om het totaal aantal in de bloktoetsantwoorden teruggevonden proposities: juiste en onjuiste proposities bij elkaar opgeteld. Daarnaast wordt het gemiddelde aantal juiste proposities weergegeven.

Verschillen tussen gemiddelden die in Tabel 10 zijn weergegeven werden getoetst door middel van variantieanalyse (ANOVA). De resultaten voor het totale aantal proposities, die door de studenten geproduceerd zijn, zijn $F(1$, 86) $=0,12, \mathrm{p}<0,73$ 
Voor het aantal juiste proposities werd gevonden $F(1,86)=0,06$, p < 0,81 . Er werden dus geen significante verschillen gevonden, zowel wat betreft het totale aantal proposities, als wat betreft het aantal juiste proposities.

Tabel 4.10

Gemiddelden en standaarddeviaties van het totale aantal proposities en juiste proposities over alle 5 bloktoetsvragen in het blok "Rechtshandeling"

Totaal aantal Juiste proposities

proposities

\begin{tabular}{lllll}
\hline Groep & Gem & SD & Gem & SD \\
\cline { 2 - 5 } & & & & \\
staf-tutoren $(\mathrm{n}=45)$ & 34,09 & 15,80 & 24,64 & 13,42 \\
student-tutoren $(\mathrm{n}=43)$ & 35,19 & 13,90 & 25,30 & 11,80 \\
\hline Totaal $(\mathrm{n}=88)$ & 34,62 & 14,83 & 24,97 & 12,59 \\
\hline
\end{tabular}

Tabel 4.11

Gemiddelden en standaarddeviaties van de descriptieve en verklarende proposities over alle 5 bloktoetsvragen in het blok "Rechtshandeling"

\begin{tabular}{lllll}
\hline & \multicolumn{2}{l}{$\begin{array}{l}\text { Descriptieve } \\
\text { proposities }\end{array}$} & \multicolumn{2}{l}{$\begin{array}{l}\text { Verklarende } \\
\text { proposities }\end{array}$} \\
\hline Groep & Gem & SD & Gern & SD \\
\hline staf-tutoren (n=45) & 3,67 & 3,33 & 21,00 & 11,01 \\
student-tutoren $(\mathrm{n}=43)$ & 4,70 & 4,15 & 20,63 & 10,25 \\
\hline Totaal $(\mathrm{n}=88)$ & 4,17 & 3,77 & 20,82 & 10,59 \\
\hline
\end{tabular}

In Tabel 4.11 zijn voor beide groepen de gemiddelde aantallen descriptieve en verklarende proposities weergegeven. Verschillen werden door middel van variantieanalyse (ANOVA) getoetst. De resultaten daarvan zijn wat betreft het aantal descriptieve proposities $F(1,86)=1,66, \mathrm{p}<0,20$. Wat betreft het aantal verklarende proposities zijn de resultaten $F(1,86)=0,03, \mathrm{p}<0,87$. Ook hier kunnen geen verschillen geconstateerd worden tussen de studenten begeleid door de staf-tutoren of de student-tutoren. (In Bijlage 4.2 zijn de 
scores voor de gegevens opgenomen in Tabel 4.10 en 4.11 weergegeven op het niveau van de afzonderlijke vragen).

\section{Propositie-analyse op de bloktoetsantwoorden van het blok "Onrechtmatig gedrag"}

\section{Methode}

\section{Proefpersonen}

Voor de vragen 1,2 , 4, en 5 werden aselect 15 studenten uitgekozen uit de groep studenten begeleid door een staflid-tutor en 15 studenten begeleid door een student-tutor. Vraag 3 is door een minder grote groep studenten beantwoord. Voor deze vraag werden de antwoorden van elk 14 studenten in beide condities gescoord. Wederom werd vermeden dat één student met meerdere antwoorden in de steekproef vertegenwoordigd zou zijn.

\section{Procedure}

De bepaling van proposities in de antwoorden op de bloktoetsvragen verliep hier op dezelfde wijze en door dezelfde beoordelaars als bij studie 1 .

\section{Resultaten}

In Tabel 4.12 zijn voor beide groepen gemiddelde aantallen geproduceerde proposities weergegeven. Het gaat daarbij om het totaal aantal in de bloktoetsantwoorden teruggevonden proposities en het aantal juiste proposities.

Tabel 4.12

Gemiddelden en standaarddeviaties van het totale aantal proposities en juiste proposities over alle 5 bloktoetsvragen in het blok "Onrechtmatig gedrag"

Totaal aantal

proposities
Juiste proposities

\begin{tabular}{lllll}
\hline Groep & Gem & SD & Gem & SD \\
\hline staf-tutoren $(n=74)$ & 33,50 & 10,63 & 21,07 & 10,10 \\
student-tutoren $(n=74)$ & 33,78 & 10,50 & 20,92 & 10,10 \\
\hline Totaal $(n=148)$ & 33,64 & 10,53 & 20,99 & 10,06 \\
\hline
\end{tabular}


Verschillen tussen gemiddelden die in Tabel 12 zijn weergegeven werden getoetst door middel van variantieanalyse (ANOVA). De resultaten voor het totale aantal proposities, die door de studenten geproduceerd zijn, zijn $F(1$, 146) $=0,03, \mathrm{p}<0,87$.

Voor het aantal juiste proposities werd gevonden $F(1,146)=0,01, \mathrm{p}<$ 0,93 . Er werden dus geen significante verschillen gevonden tussen de studenten begeleid door staf-tutoren vergeleken met studenten begeleid door student-tutoren.

In Tabel 4.13 zijn voor beide groepen de gemiddelde aantallen descriptieve en verklarende proposities weergegeven.

Verschillen werden door middel van variantieanalyse (ANOVA) getoetst. De resultaten daarvan zijn wat betreft het aantal descriptieve proposities $F(1$, $146)=3,50, p<0,06$. Wat betreft het aantal verklarende proposities zijn de resultaten $F(1,146)=0,39, \mathrm{p}<0,54$. Ook hier kunnen geen verschillen geconstateerd worden tussen de studenten begeleid door de staf-tutoren of de student-tutoren wat betreft het aantal verklarende proposities.

Tabel 4.13

Gemiddelden en standaarddeviaties van de descriptieve en verklarende proposities over alle 5 bloktoetsvragen blok "Onrechtmatig gedrag"

\begin{tabular}{|c|c|c|c|c|}
\hline \multirow[b]{2}{*}{ Groep } & \multicolumn{2}{|c|}{$\begin{array}{l}\text { Descriptieve } \\
\text { proposities }\end{array}$} & \multicolumn{2}{|c|}{$\begin{array}{l}\text { Verklarende } \\
\text { proposities }\end{array}$} \\
\hline & Gem & SD & Gem & $\mathrm{SD}$ \\
\hline staf-tutoren $(n=74)$ & 4,03 & 4,27 & 17,05 & 9,61 \\
\hline student-tutoren $(n=74)$ & 2,89 & 3,01 & 18,01 & 9,42 \\
\hline Totaal $(n=148)$ & 3,46 & 3,72 & 17,53 & 9,50 \\
\hline
\end{tabular}

Wel wordt er een bijna significant verschil gevonden wat betreft de descriptieve proposities. Studenten begeleid door stafleden beschrijven iets meer de situatie zoals voorgelegd in de casus dan de studenten begeleid door de student-tutoren.

(In Bijlage 4.3 zijn de scores voor de gegevens opgenomen in Tabel 4.12 en 4.13 weergegeven op het niveau van de afzonderlijke vragen). 


\section{Algemene discussie}

In dit hoofdstuk werd de vraag onderzocht of de leerprestaties van studenten begeleid door staf-tutoren verschillen van de leerprestaties van studenten begeleid door student-tutoren. Uitgaande van de gedachte dat staf-tutoren over meer vakinhoudelijke kennis en onderwijskundige ervaring beschikten, werd de verwachting uitgesproken dat de studenten die in deze onderwijsconditie het onderwijs zouden volgen, hogere leerprestaties zouden leveren dan de studenten begeleid door de student-tutoren. De leerprestaties van de studenten werden gemeten met behulp van een essaytoets. Deze toets betrof vijf vragen over onderwerpen die in de blokken "Rechtshandeling" en "Onrechtmatig gedrag" aan de orde kwamen. De studenten mochten op iedere toets drie vragen uit de vijf aangeboden vragen ter beantwoording kiezen.

Geconstateerd werd dat zowel in het blok "Rechtshandeling" als in het blok "Onrechtmatig gedrag" geen betekenisvolle verschillen in leerprestaties tussen beide experimentele condities optraden. Dit betrof zowel de leerprestaties op het niveau van het eindcijfer (drie uit vijf vragen) als op het niveau van de afzonderlijke vragen. Enige mogelijke bezwaren tegen deze resultaten, zoals de mogelijkheid dat de studenten in beide condities andere vragen gekuzen liaduen of dat de tutoren andere leerstof aan de orde gesteld zouden kunnen hebben, werden weerlegd. In één enkel geval werd in het blok "Onrechtmatig gedrag" op het niveau van de afzonderlijke vragen wel een significant verschil gevonden, namelijk wanneer een niet-vakinhoudelijk deskundige tutor verwijderd werd uit de groep staf-tutoren. Dan bleek bij een vergelijking dat de studenten begeleid bij de staf-tutoren betere leerprestaties haalden.

Onder erkenning van het belangrijkste bezwaar dat tegen toetsing via essayvragen door veel toetsdeskundigen wordt ingebracht, namelijk de geringe betrouwbaarheid van de beoordelingen, is gezocht naar een ander instrument om de antwoorden van de studenten nogmaals te vergelijken. Daarbij is de keuze gevallen op de methode van propositie-analyse. Bij deze methode wordt elk kort zinsverband (uitgedrukt in onderwerp en gezegde-zinnen) geanalyseerd. Onderzocht werd, door middel van een aselecte steekproef uit alle antwoorden, of er verschillen tussen beide condities optraden wat betreft het totale aantal proposities, juiste proposities, descriptieve en explanatoire propusities. Ook met behulp van deze meer analytisch methode werden geen verschillen van betekenis gevonden.

Uit bovengenoemd onderzoek lijkt derhalve de conclusie getrokken te mogen worden dat studenten begeleid door staf-tutoren geen betere leerprestatics leveren. De verwachting dat studenten profiteren van de relatief grotere hoeveelheid kennis en de ruimere didactische ervaring van stafleden, wordt in onderhavig onderzoek niet bewaarheid. Het feit dat de resultaten stabiel bleken over de twee veldstudies heen, versterkt deze conclusie. 
Met dit resultaat is uiteraard nog niet verklaard waarom de begeleidingsactiviteiten van de student-tutoren dezelfde leerprestaties opleveren als de begeleidingsactiviteiten van de staf-tutoren. Zo rijst de vraag of studenttutoren hun relatieve kennisachterstand en gebrek aan onderwijservaring wellicht compenseren door zich, tijdens de begeleiding van hun onderwijsgroepen, anders te gedragen dan stafleden. Eveneens mag de veronderstelling niet uitgesloten worden dat studenten begeleid door student-tutoren misschien harder werken, bijvoorbeeld omdat ze minder vertrouwen hebben in de inhoudelijke deskundigheid van hun tutor. Resultaten van onderzoek naar deze laatste vraag "besteden studenten begeleid door student-tutoren meer, evenveel of minder tijd aan zelfstudie dan studenten begeleid door staf-tutoren" worden in het volgende hoofdstuk besproken. 



\section{Verschillen in besteding van studietijd in docentgeleide en studentgeleide onderwijs- groepen}

\section{Resultaten van studietijdmetingen}

\section{Inleiding}

In Hoofdstuk 4 werd geconstateerd dat geen verschillen in leerprestaties gevonden konden worden tussen studenten begeleid door student-tutoren en studenten begeleid door staf-tutoren. Deze constatering had zowel betrekking op de totaalscores als op de scores van de afzonderlijke toetsvragen van beide bloktoetsen. Ook werden geen verschillen gevonden bij een meer precieze analyse van de antwoordprotocollen. Als docent-tutoren al meer invloed hebben op het leren van hun studenten dan is die invloed dus in ieder geval niet direct observeerbaar. Een van de redenen voor deze uitkomst zou kunnen zijn dat studenten begeleid door de student-tutoren wellicht meer tijd besteden aan zelfstudie bijvoorbeeld om eventueel tekortschieten van die student-tutoren te compenseren. Studenten begeleid door student-tutoren weten natuurlijk dat hun begeleiders twee tot drie jaar verder met hun studie zijn. Het is niet uitgesloten dat ze zich bezorgd maken over het kennisniveau en overzicht van hun begeleider. In interviews afgenomen in de laatste weken van beide blokken uitten sommige studenten hun bezorgdheid over de inhoudelijke kwalificaties van hun student-tutor. Een student(e) merkte bijvoorbeeld hierover op: "In het vorige blok had ik een staflid als tutor en dat was ideaal. Op iedere vraag die je stelde kreeg je een antwoord. ... Dat gaf veiligheid. Als die tutor iets zei, dan dacht ik 'ja dat klopt', terwijl ik nu denk 'nou misschien weet jij het ook wel niet helemaal zeker'".

In dit hoofdstuk staat de veronderstelling centraal, dat studenten in studentgeleide groepen een mogelijk relatief tekort aan overzicht en diepgang bij hun begeleiders compenseren door harder te werken, dat is: door meer tijd aan zelfstudie te besteden. Onderzocht werd of studenten begeleid door student-tutoren meer tijd besteden aan zelfstudie dan studenten begeleid door staflid-tutoren. De 
vraag of student-tutoren inderdaad relatief tekortschieten zal pas verderop in dit Hoofdstuk aan de orde komen. Nu concentreren we ons in eerste instantie op de vraag of de tijd besteed aan zelfstudie verschilt.

\section{Methoden van studietijdmeting}

Studietijd kan op verschillende manieren gemeten worden. Everwijn en Muggen (1973) onderscheiden twee benaderingen: tijdschrijf- en schattingsmethoden. Tijdschrijfmethoden hebben met elkaar gemeen, dat gebruik gemaakt wordt van een studietijdformulier waarop gedetailleerd kan worden aangegeven, hoeveel tijd men aan de onderscheiden curriculumonderdelen heeft besteed. Tijdschrijfmethoden kunnen opgedeeld worden in verschillende subvormen. Bij de longitudinale methode wordt aan een steekproef of populatie van de studenten gevraagd om, gedurende de looptijd van het onderzoek, iedere dag een studietijdformulier in te vullen en dit terug te sturen naar de onderzoeker. De transversale methode is een variant op de longitudinale methode, waar de populatie van te onderzoeken studenten wordt opgedeeld in subgroepen die elk rapporteren over hun studietijdbesteding gedurende een bepaalde dag van de onderzoeksperiode. Ook combinaties van de transversale en longitudinale methode worden gebruikt, bv. matrix-sampling (De Gruijter, 1981).

De tweede groep methoden om studietijd te meten is die van de schattingsmethoden. Bij de schattingsmethode wordt na afloop van een studiefase aan de studenten gevraagd schattenderwijs aan te geven, hoeveel tijd zij aan de in die fase gedoceerde vakken hebben besteed. Everwijn en Muggen onderscheiden drie verschillende vormen van schattingsmethoden. De eerste benadering is de methode van absolute schattingen. Aan de student wordt gevraagd, met behulp van een eenvoudige rekenprocedure die beoogt het aantal schattingsfouten en de grootte ervan zo klein mogelijk te maken, een schatting van de bestede studietijd voor een bepaald cursusonderdeel te geven. $\mathrm{Bij}$ de methode van de paarsgewijze vergelijkingen geven de studenten aan aan welk vak van steeds twee aangeboden vakken zij de meeste studietijd hebben besteed. Via een bepaalde berekeningsmethode kan dan de zwaarte van de afzonderlijke vakken bepaald worden (Crombag, Roskam \& Meuwese, 1973). De derde methode in deze categorie is die van verhoudingsgewijze schattingen, waarbij van de student wordt gevraagd de aan een vak bestede tijd te schatten in verhouding tot de tijdsduur van een studieonderdeel, waaraan door de onderzoeker een bepaalde numerieke waarde is toegekend en waarvan de werkelijk bestede tijd bekend is.

In het hier beschreven onderzoek is zowel gebruikt gemaakt van de longitudinale tijdschrijfmethode, waarbij studenten dagelijks bijhouden hoeveel tijd zij aan hun studie besteed hebben, als van de methode van de absolute schattingen. De aandacht zal voomamelijk gericht zijn op de uren zelfstudie die studenten besteed hebben ten behoeve van de onderwijsgroep. In de onderwijsgroep wordt door de studenten bepaald waarop zij hun aandacht zullen richten 
tussen de onderwijsgroepsbijeenkomsten in. De studenten formuleren daartoe leerdoelen, gemeenschappelijke studieopdrachten of vragen die naar aanleiding van de analyse van de blokboektaken bij hen zijn opgekomen en die zij nader willen uitzoeken. Eerst zal de tijdsbesteding van de studenten in het blok "Rechtshandeling" beschreven worden. Achtereenvolgens komt in deze paragraaf het zelfstudiepatroon van de studenten over alle curriculum-onderdelen van het blok aan de orde. Vervolgens zal besproken worden in hoeverre er verschillen geconstateerd kunnen worden tussen studenten begeleid door student-tutoren en studenten begeleid door staf-tutoren. In de daarop volgende paragraaf zal de tijdsbesteding van de studenten in het blok "Onrechtmatig gedrag" gerapporteerd worden. Telkens worden na een korte bespreking van het algemene zelfstudiepatroon de resultaten gepresenteerd van de studenten onder de beide experimentele condities.

\section{Studietijdbesteding in het blok "Rechtshandeling"}

\section{Methode}

\section{Proefpersonen}

Van de 243 studenten die gevraagd werden deel te nemen aan het wekelijks invullen van het studietijdformulier, weigerden zevenenveertig studenten op persoonlijke gronden in het tijdschrijfonderzoek te participeren. Vijfentwintig studenten haakten tussentijds af ${ }^{1}$. Aan het onderzoek namen uiteindelijk 171 studenten deel; dit is $70 \%$ van alle studenten die onderwijs volgden, begeleid door een student- of een staflid-tutor. Alle deelnemende studenten volgden voor de eerste keer dit onderwijsblok.

\section{Materiaal}

Aan de studenten werd wekelijks een studietijdregistratieformulier (zie Bijlage 5.1) en een antwoordenveloppe uitgereikt.

Ten behoeve van het onderzoek naar de studietijdbesteding door middel van de methode van absolute schattingen, kregen alle studenten in de laatste week van de blokperiode de volgende vraag voorgelegd "Hoeveel tijd heeft u, gemiddeld genomen, per week aan literatuurstudie voor de onderwijsgroep besteed?". Deze vraag was opgenomen in de vragenlijst, die werd voorgelegd aan alle studenten die deelgenomen hadden aan het onderwijs in het desbetreffende blok.

\section{Procedure}

Voor deelname aan het onderzoek naar studietijdbesteding, door middel van de tijdschrijfmethode, werden alle studenten uitgenodigd die geplaatst waren in een

Als trouwe tijdschrijvers werden die studenten aangemerkt die $80 \%$ van de studietijdformulieren inleverden. 
onderwijsgroep begeleid door een student-tutor of een staf-tutor. De uitnodiging werd zowel mondeling als schriftelijk gedaan. De mondelinge uitnodiging en een toelichting op het onderzoek vond plaats in de onderwijsgroepsbijeenkomsten van de tweede blokperiode. De schriftelijke uitnodiging vond plaats via een brief waarin alle studenten de aard van en werkwijze bij dit onderzoek nogmaals werd uitgelegd (Zie Bijlage 5.2). Aan de studenten werd gevraagd dagelijks op een studietijdformulier bij te houden hoeveel tijd zij besteedden aan zelfstudie voor en deelname aan de verschillende onderwijsactiviteiten gedurende het blok. De studenten ontvingen voor hun deelname een kleine financiële vergoeding.

Het studietijdformulier werd met een antwoordenveloppe wekelijks door de onderzoeker aan de studenten uitgedeeld in de pauze van hun onderwijsgroepsbijeenkomst. Gelijktijdig werd het formulier van de voorafgaande week opgehaald. De ingeleverde formulieren werden nog op dezelfde dag geregistreerd. Studenten waarvan het formulier ontbrak werden meteen schriftelijk aangemaand het formulier zo spoedig mogelijk in te leveren.

\section{Resultaten en discussie}

\section{Totaal bestede studietijd}

Eerst zal een beeld gegeven worden van het studietijdpatroon tijdens het blok "Rechtshandeling". Daartoe worden de resultaten gerapporteerd van alle studenten op de verschillende curriculumonderdelen waaruit het blok "Rechtshandeling" bestond. Vervolgens zal de tijdsbesteding van de studenten begeleid door student-tutoren met de studietijdbesteding van door staflid-tutoren begeleide studenten vergeleken worden.

Figuur 5.1 geeft een overzicht van het gemiddeld aantal uren zelfstudie per week voor de verschillende curriculumonderdelen. Van boven naar beneden staan vermeld:

- de gemiddelde studietijd per week voor het practicum (pract),

- de gemiddelde studietijd per week voor de colleges (coll),

- de gemiddelde studietijd per week voor de onderwijsgroep (owg),

- de som van de gemiddelde studietijd per week van alle bovengenoemde onderdelen (totale zelfstudietijd).

De daling van de studie-activiteiten in de vierde week is het gevolg van een onderwijsvrije periode in het blok. In die week vond namelijk het carnaval plaats. In de laatste week, week 9, is het gemiddelde berekend over drie studiedagen, omdat op donderdagmorgen de bloktoets afgenomen werd. De gemiddelde zelfstudietijd voor de leerdoelen van de onderwijsgroep over alle 9 studieweken van dit blok was 10,5 uur per week met een standaarddeviatie (sd) van 4,4 uur. Voor het practicum werd gemiddeld 2,1 uur per week aan zelfstudietijd besteed ( $s d=1,1$ uur); voor het college "Rechtsgeschiedenis" was dit gemiddeld 1,6 uur (sd $=1,2$ uur). 
Figuur 5.1

Gemiddelde tijd voor zelfstudie per week voor de verschillende curriculumonderdelen, blok "Rechtshandeling"

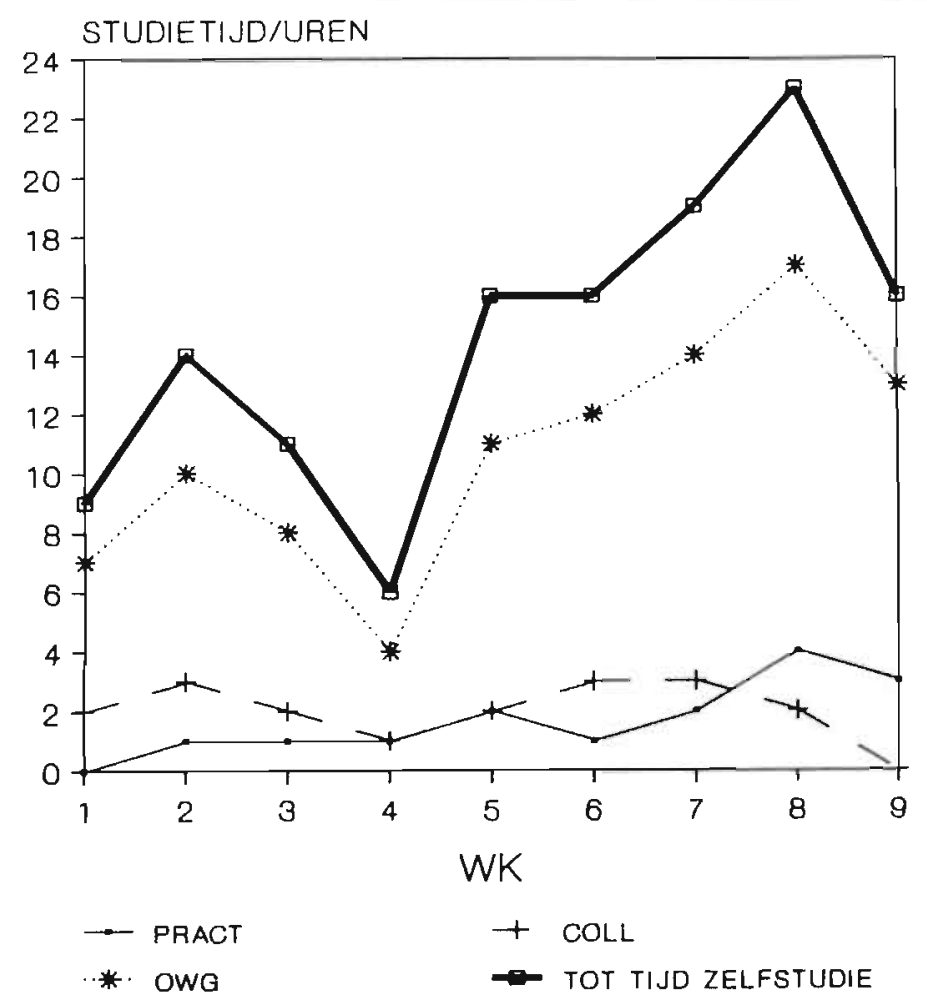

Worden de gemiddelden berekend, nadat week 4 (de camavalsweek) buiten de berekening is gehouden, dan zijn de resultaten als weergegeven in Tabel 5.1.

\section{Tabel 5.1}

Gemiddeld aantal uren zelfstudietijd per week (en standaarddeviatie) na verwijdering van de camavalsweek, blok "Rechtshandeling" ( $n=171)$

Activiteit:

Gemiddelde

Standaarddeviatie

zelfstudie voor

onderwijsgroep

practicum

11,4

college

2,3

4,7

1,7

1,2

1,3 
Voor wat betreft de methode van de absolute schatling werd na afloop van het onderwijsblok "Rechtshandeling" aan alle cursisten gevraagd een vragenlijst in te vullen waarin zij hun mening kenbaar konden maken over de verschillende curriculumonderdelen van dit blok. In deze vragenlijst werd ook aan de studenten gevraagd een schatting te geven van de hoeveelheid tijd die zij besteed hadden aan studie voor de onderwijsgroep. Gevraagd werd: "Hoeveel tijd heeft u, gemiddeld genomen, per week aan literatuurstudie voor de onderwijsgroep besteed?". 286 Studenten vulden deze vragenlijst in, dat is $80 \%$ van alle eerstejaarsstudenten die onderwijs volgden in dit blok. Alle geretourneerde vragenlijsten waren voorzien van het examennummer van de betreffende studenten. Op de vraag hoeveel tijd zij besteed hadden aan zelfstudie, antwoordden de studenten dat zij gemiddeld 16 uur per week studeerden voor de leerdoelen van de onderwijsgroep (de standaarddeviatie was 7,8 uur). De studenten die meededen aan het tijdschrijfonderzoek ("de tijdschrijvers") schatten hun aan zelfstudie bestede tijd ten behoeve van de leerdoelen voor de onderwijsgroep iets lager in dan degenen die niet aan dit onderzoek meededen. De "tijdschrijvers" vermelden dat zij gemiddeld 15,5 uur per week (standaarddeviatie 7,5 uur) besteedden aan zelfstudie ten behoeve van de onderwijsgroep ${ }^{2}$. De gemiddelde tijdschrijfgegevens van de individuele tijdschrijvende studenten werden gecorreleerd met de antwoorden van de studenten op de eerder genoemde vraag. Het verband tussen de schatting van de tijdschrijvers en de hoeveelheid zelfstudietijd voor de onderwijsgroep opgegeven op de studietijdformulieren bedroeg $r=0,61$. De hoeveelheid bestede studietijd als geschat blijkt dus redelijk te correleren met de werkelijk bestede studietijd. Deze bevinding komt niet overeen met eerdere bevindingen uit soortgelijk onderzoek van Crombag, De Gruijter, Van de Ende en Vos (1980). Zij vonden correlaties die varieerden tussen de waarden 0,07 en 0,43 . Crombag et al. merken dan ook op dat de geschatte studietijd van studenten een tamelijk onbetrouwbare maat is voor de werkelijk bestede studietijd. De lage correlaties van Crombag et al. zouden echter veroorzaakt kunnen worden door het gegeven dat hun studenten na afloop van een aanzienlijk langere periode (14 à 17 weken) moesten schatten hoeveel tijd zij besteed hadden aan zelfstudie dan de studenten in dit onderzoek.

Tober (1985) meldt bijvoorbeeld vergelijkingen tussen tijdschatting en tijdschrijven waarbij de "resultaten vrij aardig met elkaar overeenstemmen" (p. 185) bij cursussen waarbij de onderwijsperiode korter is. Tober geeft echter wel vergelijkingen voor de gehele groep respondenten, uitgedrukt in uren, maar geeft geen correlationele waarden. Tijdschatting van bestede zelfstudietijd over een

${ }^{2}$ Deze schatting is wat hoger dan de tijd gemeten met de tijdschrijfmethode, maar komt overigens bijna overeen met de totale zelfstudietijd: 15,4 uur. 
relatief korte onderwijsperiode (bv. twee maanden) lijkt een tamelijk reëel becld te geven van de werkelijk bestede studietijd van de studenten ${ }^{3}$.

Verschillen in tijdsbesteding tussen studenten begeleid door staf-tutoren en student-tutoren

Tabel 5.2 geeft de tijdsbesteding weer in uren zelfstudie over de gehele blokperiode onderscheiden naar de twee condities van het experiment.

Verschillen tussen gemiddelden die in Tabel 5.2 zijn weergegeven werden getoetst door middel van variantieanalyse (ANOVA). De resultaten daarvan zijn $F(1,169)=5,95, \mathrm{p}<0,02$. Dat betekent dat de studenten begeleid door de student-assistenten significant meer tijd besteed hebben aan zelfstudie dan de studenten begeleid door de staf-tutoren.

Tabel 5.2

Gemiddeld aantal uren zelfstudie voor de onderwijsgroepsactiviteiten (en standaarddeviatie) berekend over alle negen weken in het blok 'Rechtshandeling'

Experimentele conditie $\quad \mathrm{N} \quad$ Gemiddelde Standaarddeviatie

Groep begeleid door

staf-tutoren

96

10,6

4,4

Groep begeleid door

student-tutoren

75

12,3

4,8

Totaal

171

11,4

4,7

Worden deze verschillen ook gevonden voor die onderdelen van het blok waarbij de begeleiding van de tutor geen rol speelt? Tabel 5.3 geeft een overzicht van de gemiddelde hoeveelheid tijd besteed aan zelfstudie ten behoeve van het practicum "Casus oplossen" en het college "Rechtsgeschiedenis". Daarnaast is

${ }^{3}$ (N.B. Interessant is dat de tijdschrijvers significant hoger scoorden op de bloktoets van het blok "Rechtshandeling" dan de niet-tijdschrijvers (dit zijn de studenten die begeleid werden door onderwijsmedewerkers en assistenten-in-opleiding). Voor blok 1.3 is het significantienivo $\mathrm{p}<.01$. Zowel Crombag \& Vos (1982) als Van Gelderen en Ten Cate (1985) hebben deze verschillen tussen tijdschrijvers en niet-tijdschrijvers in hun onderzoeken ook geconstateerd. Er worden door hen twee hypothesen ter verklaring aangevoerd: de stimuleringshypothese (door tijdschrijven worden de studenten zich bewuster van het aantal studie-uren dat ze maken en doen ze er wellicht een schepje bovenop) en de selectie-hypothese (tijdschrijvers onderscheiden zich van niet-tijdschrijvers (en dan met name de non-respondenten) door bepaalde vrij stabiele kenmerken: ijverig, grote betrokkenheid bij studie). Beide auteur-duo's neigen tot de laatste hypothese. 
in de tabel ook opgenomen de gemiddelde hoeveelheid tijd die de studenten per week aan deelname aan deze onderdelen besteedden.

Verschillen in studietijd tussen de studenten begeleid door staf- en studenttutoren kunnen niet teruggevonden worden bij de overige curriculumonderdelen waarvoor zelfstudie vereist werd. Wat betreft de verschillen in tijd besteed aan onderwijsdeelname wordt een klein significant verschil gevonden op het onderdeel: deelname aan de hoorcolleges "Rechtsgeschiedenis." Dit onderdeel werd los van de overige activiteiten verzorgd.

Uit dit resultaat kan derhalve geconcludeerd worden dat er geen verschillen optreden bij niet-onderwijsgroep gerelateerde onderwijsactiviteiten. De aanwezigheid van student-tutoren dan wel staf-tutoren lijkt derhalve invloed te hebben op de hoeveelheid tijd die de studenten aan studie besteden.

\section{Tabel 5.3}

Verschillen tussen studenten begeleid door student-tutoren en staf-tutoren m.b.t. de andere curriculumactiviteiten in het blok 'Rechtshandeling', gemiddeld over de acht onderwijsweken van het blok (exclusief de carnavalsweek)

\begin{tabular}{llllllll}
\hline Activiteit & $\begin{array}{l}\text { Groep be- } \\
\text { geleid door }\end{array}$ & N & Gem & SD & $\begin{array}{l}\text { F-geobser- } \\
\text { veerd }\end{array}$ & df & $\begin{array}{l}\text { p-geob- } \\
\text { serveerd }\end{array}$ \\
\hline zelfstudie & staf-tutor & 96 & 2,2 & 1,2 & 0,55 & 169 & n.s. \\
practicum & student-tutor & 75 & 2,3 & 1,3 & & & \\
zelfstudie & staf-tutor & 96 & 1,8 & 1,3 & 1,57 & 169 & n.s. \\
college & student-tutor & 75 & 1,7 & 1,2 & & & \\
deelname & staf-tutor & 96 & 3,3 & 0,6 & 1,62 & 169 & n.s. \\
$\begin{array}{l}\text { onderwijs- } \\
\text { groep }\end{array}$ & student-tutor & 75 & 3,4 & 0,7 & & & \\
deelname & staf-tutor & 96 & 2,0 & 0,6 & 0,86 & 169 & $\mathrm{n} . \mathrm{s.}$ \\
practicum & student-tutor & 75 & 2,1 & 0,6 & & & \\
$\begin{array}{l}\text { deelname } \\
\text { college }\end{array}$ & $\begin{array}{l}\text { staf-tutor } \\
\text { student-tutor }\end{array}$ & 96 & 1,1 & 0,6 & 4,32 & 169 & $<0,05$ \\
\hline
\end{tabular}

Uit de gegevens uit Tabel $5.2 \mathrm{kan}$ afgeleid worden dat de studenten begeleid door student-tutoren significant meer tijd besteden aan zelfstudie voor de onderwijsgroep dan de studenten begeleid door de staf-tutoren. Studenten begeleid door de student-tutoren blijken iedere week meer tijd, hoewel niet altijd significant meer, aan zelfstudie te besteden dan studenten begeleid door staflidtutoren. Significante verschillen werden gevonden zowel in de begin- als in de 
slotweken van het blok. Het verschil tussen beide groepen werd dus niet veroorzaakt door een eindspurt van de studenten begeleid door de student-tutoren. Uit het feit dat dergelijke verschillen niet geconstateerd werden bij de andere onderwijsactiviteiten waarvoor ook zelfstudie noodzakelijk was, werd geconcludeerd dat het verschil in tijd voor zelfstudie voor de onderwijsgroep een effect betreft dat gebonden lijkt te zijn aan de achtergrond van de tutor. Aan het einde van dit hoofdstuk zullen we op deze bevinding nader terugkomen.

\section{Studietijdbesteding in het blok "Onrechtmatig gedrag"}

\section{Methode}

\section{Proefpersonen}

Aan het onderzoek namen 191 studenten deel. Tweeënveertig studenten weigerden te participeren, achtendertig studenten haakten tussentijds af, dat wil zeggen dat zij minder dan $80 \%$ van de tijdschrijfformulieren retourneerden.

Aan het onderzoek namen uiteindelijk 111 studenten deel, dit is $58 \%$ van de studenten die in een onderwijsgroep zaten begeleid door een student- tutor of staflid-tutor.

\section{Materiaal}

Ook in dit blok werd hetzelfde studietijdregistratieformulier gebruikt als in het blok "Rechtshandeling".

Voor het onderzoek naar de studietijdbesteding door middel van de methode van absolute schattingen, kregen alle studenten in de laatste week van de blokperiode, weer in de vragenlijst de vraag voorgelegd hoeveel tijd zij, gemiddeld genomen, per week aan literatuurstudie voor de onderwijsgroep besteed hadden.

\section{Procedure}

Voor de aanvang van het blok "Onrechtmatig gedrag" werden 352 studenten aselect toegewezen aan 32 onderwijsgroepen begeleid door stafleden, studentassistenten, onderwijsmedewerkers of assistenten-in-opleiding. Eerst werden alle studenten die in het blok "Rechtshandhaving" niet ingedeeld waren in de onderwijsgroepen begeleid door staf-tutoren of student-tutoren aselect toegewezen aan onderwijsgroepen begeleid door deze categorieën tutoren. Met deze voorselectie werd beoogd zoveel mogelijk "nieuwe" studenten in het onderzoek te betrekken. Daarna werden de overige studenten aselect ingedeeld bij de onderwijsgroepen.

Voor deelname aan het tijdschrijfonderzoek in dit blok werden uitgenodigd alle studenten die toegedeeld waren aan één van beide experimentele condities. Aangezien bij dit blok minder stafleden en student-tutoren betrokken waren, werden ook een aantal studenten die begeleid werden door een onderwijsmedewerker of een assistent-in-opleiding gevraagd mee te doen aan het onderzoek. Hiermee werd tevens voorkomen dat de studenten de indruk kregen dat het 
onderzoek slechts een vergelijking beoogde tussen studenten begeleid door student-tutoren en studenten begeleid door staf-tutoren. In dit verslag zullen de gegevens van de groep studenten begeleid door toegevoegd docenten dan wel assistenten-in-opleiding echter buiten beschouwing blijven. De tijdschrijfgegevens van deze studenten verschilden nergens van de gegevens van de beide andere condities.

De uitnodiging mee te doen aan het tijdschrijfonderzoek vond plaats op dezelfde wijze als beschreven in de vorige paragraaf. De studietijdformulieren werden volgens dezelfde procedure als bovenstaand beschreven door de onderzoeker uitgedeeld, verzameld en geregistreerd.

\section{Resultaten en discussie}

\section{Totaal bestede studietijd}

De deelname van alle studenten betrokken bij het tijdschrijfonderzoek in het blok "Onrechtmatige gedrag" vertoont tijdens de onderwijsperiode hetzelfde studietijdpatroon als in de voorafgaande blokperiode (zie Figuur 5.2). Van boven naar beneden staan vermeld:

- de gemiddelde studietijd per week voor het practicum (pract),

- de gemiddelde studietijd per week voor de colleges (coll),

- de gemiddelde studietijd per week voor de onderwijsgroep (owg),

- de som van de gemiddelde studietijd per week van alle bovengenoemde onderdelen (totale zelfstudietijd).

$\mathrm{Na}$ drie weken waarin de studenten steeds meer tijd besteden aan zelfstudie, treedt, niet onverwacht, een daling in. Deze daling wordt veroorzaakt door een periode van twee weken waarin de studenten een opstel over een juridisch onderwerp moeten afronden. Daarna komen de zelfstudie-activiteiten weer, hoewel langzaam, op gang. Pas in de achtste week van het blok zijn de studenten weer terug op het niveau van week drie. In de laatste twee weken voor de bloktoets vindt er een eindspurt plaats.

De gemiddelde hoeveelheid zelfstudietijd voor de activiteiten samenhangende met de onderwijsgroepsbijeenkomsten over alle 10 weken van dit blok is 11,9 uur per week met een standaarddeviatie (sd) van 4,6 uur; voor het practicum "Het juridisch debat" wordt gemiddeld 1,3 uur per week zelfstudie uitgetrokken (sd = 0,9 uur) en voor het college "Rechtsgeschiedenis" gemiddeld 1,7 uur (sd $=1,4$ uur). Worden de gemiddelden berekend, nadat de weken 4 en 5 (de opstelweken) buiten beschouwing worden gelaten, dan zijn de resultaten als weergegeven in Tabel 5.4 . 
Figuur 5.2

Gemiddelde tijd voor zelfstudie per week voor de verschillende curriculumonderdelen, blok "Onrechtmatig gedrag"

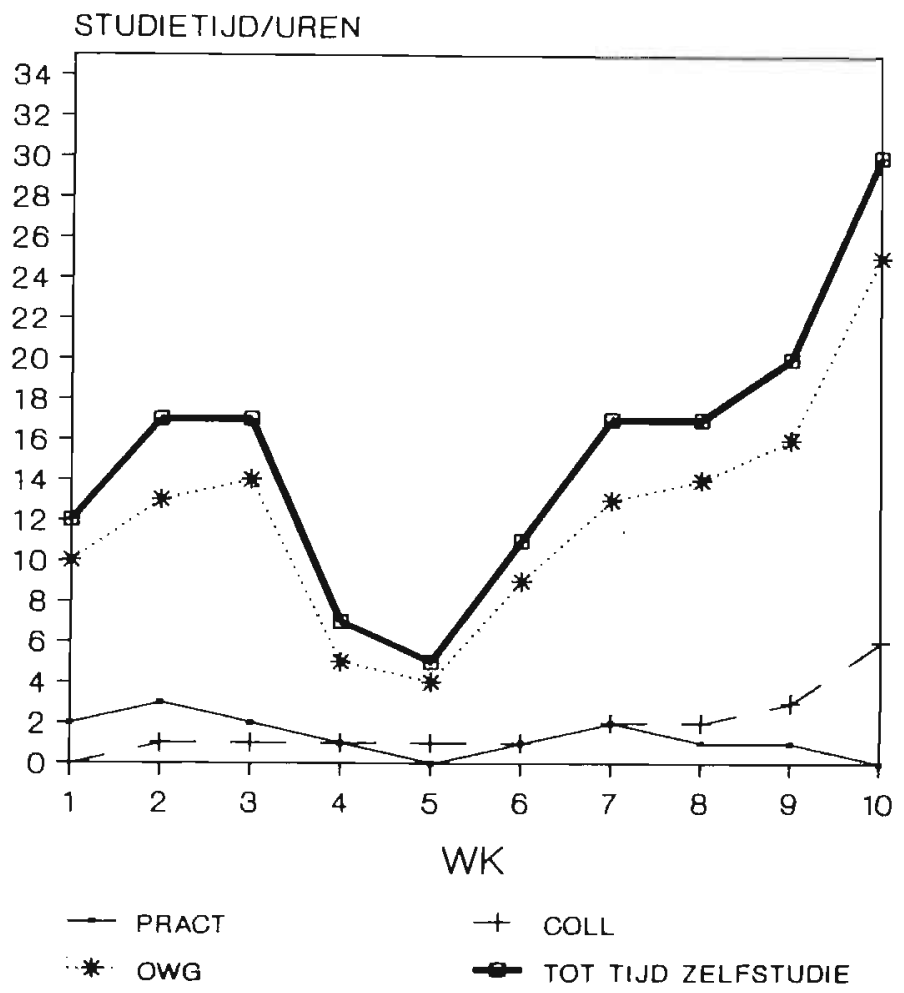

Tabel 5.4

Gemiddeld aantal uren zelfstudietijd per week (en standaarddeviatie) na verwijdering van de opstelweken, blok "Onrechtmatig gedrag" $(n=111)$

Activiteit: $\quad$ Gemiddelde Standaarddeviatie
zelfstudie voor

\section{zelfstudie voor}

onderwijsgroep

practicum

13,9

college

1,6
1,9

5,1

1,1

1,6 
Ook hier zijn de tijden voor zelfstudie verkregen door middel van de studietijdformulieren vergeleken met de hoeveelheid tijd besteed aan literatuurstudie voor de onderwijsgroep die de studenten schatten na afloop van het blok. De studenten konden het gemiddeld aantal uren zelfstudie voor de onderwijsgroep invullen op een vragenlijst die direct na afloop van het blok aan hen werd voorgelegd. 247 Studenten beantwoorden de vraag, dat is $82 \%$ van alle eerstejaarsstudenten.

De studenten gaven op dat zij gemiddeld 17,5 uur per week aan zelfstudie voor de onderwijsgroep besteed hadden (standaarddeviatie was 8,1 uur). De studenten die wekelijks de studietijdformulieren in gevuld hadden (de tijdschrijvers) schatten dat zij gemiddeld 19 uur per week besteed hadden aan zelfstudie (standaarddeviatie 8 uur) ${ }^{4}$. De correlatie tussen de geschatte tijd en de werkelijk opgegeven tijd van de tijdschrijvers is $r=0,62$ wanneer de tijd besteed aan zelfstudie voor de leeractiviteiten over alle 10 blokweken wordt berekend. Het verschil tussen bestede studietijd zoals gemeten met het tijdschrijfformulier en de achteraf geschatte studietijd is alleszins acceptabel.

Verschillen in tijdsbesteding tussen studenten begeleid door staf-tutoren en student-tutoren

Tabel 5.5 geeft een overzicht van de tijdsbesteding van de studenten begeleid door staf-tutoren en studenten begeleid door student-tutoren van alle reguliere onderwijsweken, dus exclusief de opstelweken.

\section{Tahel 5.5}

Gemiddeld aantal uren zelfstudie voor de onderwijsgroepsactiviteiten (en standaarddeviatie) berekend over alle reguliere onderwijsweken in het blok 'Onrechtmatig gedrag'

Experimentele conditie N $\quad$ Gemiddelde Standaarddeviatie

Groep begeleid door

staf-tutoren

49

14,0

5,6

Groep begeleid door

student-tutoren

62

13,8

4,6

Totaal

111

13,9

5,1

Verschillen tussen gemiddelden die in Tabel 5.5 zijn weergegeven, werden getoetst door middel van variantie analyse (ANOVA). De resultaten daarvan zijn

${ }^{4}$ Ook hier komt de scharting van de tijdschrijvers wat hoger uit dan de tijd gemeten met de tijdschrijfmethode, maar komt overigens aardig overeen met de totaal opgegeven hoeveelheid zelfstudietijd: 17,4 uur. 
$F(1,109)=.04, \mathrm{p}<0,84$. Dat betekent dus dat de studenten begeleid don de student-tutoren niet meer tijd besteed hebben aan zelfstudie voor de activiteiten van de onderwijsgroep dan de studenten begeleid door de staf-tutoren. In tegenstelling tot de vorige blokperiode worden in het blok "Onrechtmatig gedrag" dus geen tijdsverschillen in uren zelfstudie voor de activiteiten van de onderwijsgroep tussen de studenten begeleid door student-tutoren en de studenten begeleid door staflid-tutoren.

Tabel 5.6 geeft een overzicht van de verschillen in gemiddelden (en standaarddeviaties) weer voor de zelfstudie van de studenten ten behoeve van het practicum "Het juridisch debat" en het college "Rechtsgeschiedenis" en de verschillen in gemiddelden (en standaarddeviaties) in deelname aan de verschillende onderwijsactiviteiten.

\section{Tabel 5.6}

Verschillen tussen studenten begeleid door student-tutoren en staf-tutoren met betrekking tot de andere curriculumactiviteiten in het blok 'Onrechtmatig gedrag", gemiddeld over de acht onderwijsweken van het blok (exclusief de opstelweken)

\begin{tabular}{|c|c|c|c|c|c|c|c|}
\hline Activiteit & $\begin{array}{l}\text { Groep be- } \\
\text { geleid door }\end{array}$ & $\mathrm{N}$ & Gem & $\mathrm{SD}$ & $\begin{array}{l}\text { F-geobser- } \\
\text { veerd }\end{array}$ & df & $\begin{array}{l}\text { p geobser- } \\
\text { veerd }\end{array}$ \\
\hline zelfstudie & staf-tutor & 49 & 1,6 & 1,1 & 0,05 & 109 & n.s. \\
\hline practicum & student-tutor & 62 & 1,6 & 1,0 & & & \\
\hline zelfstudie & staf-tutor & 49 & 2,1 & 1,6 & 1,48 & 109 & n.s. \\
\hline college & student-tutor & 62 & 1,7 & 1,5 & & & \\
\hline deelname & staf-tutor & 49 & 3,3 & 0,5 & 4,04 & 109 & $<0,05$ \\
\hline $\begin{array}{l}\text { onderwijs- } \\
\text { groep }\end{array}$ & student-tutor & 62 & 3,1 & 0,6 & & & \\
\hline deelname & staf-tutor & 49 & 0,9 & 0,3 & 21,10 & 109 & $<0,001$ \\
\hline practicum & student-tutor & 62 & 1,1 & 0,3 & & & \\
\hline deelname & staf-tutor & 49 & 0,9 & 0,5 & 1,92 & 109 & n.s. \\
\hline college & student-tutor & 62 & 1,0 & 0,6 & & & \\
\hline
\end{tabular}

Hoewel er geen overall verschillen in tijd besteed aan zelfstudie voor de overige curriculumonderdelen geconstateerd kunnen worden, worden wel significante verschillen gevonden wat betreft deelname aan curriculumonderdelen. Studenten begeleid door staf-tutoren nemen meer deel aan de onderwijsgroepsbijeenkom- 
sten; studenten begeleid door student-tutoren besteden meer tijd aan het volgen van het practicum "Het juridisch debat".

\section{Algemene discussie}

Uit de tijdschrijfgegevens van de blokken "Rechtshandeling" en "Onrechtmatig gedrag" kan afgeleid worden dat er geen verschillen optreden in de hoeveelheid tijd besteed aan zelfstudie voor die curriculumonderdelen waarbij het onderwijs niet verzorgd wordt door een tutor, te weten de practica en het college "Rechtsgeschiedenis". Hieruit lijkt geconcludeerd te mogen worden dat eventuele verschillen in zelfstudie ten behoeve van de onderwijsgroepsbijeenkomsten moeten samenhangen met de aan- of aanwezigheid van staf-tutoren in de onderwijsgroepen. In dit hoofdstuk werd de veronderstelling geuit dat studenten begeleid door student-tutoren wellicht een mogelijke relatieve kennisachterstand van deze tutoren, in vergelijking tot staf-tutoren, compenseren door meer tijd te besteden aan het bestuderen van de leerstof die voortvloeit uit hun activiteiten voor de onderwijsgroep.

Of er inderdaad reden is voor de veronderstelling dat student-tutoren over minder kennis beschikken, werd op verschillende manieren nagegaan.

In de eerste plaats werd op twee manieren geprobeerd de deskundigheid van de tutoren na te gaan, nl. met behulp van een meting van de inhoudelijke kennis van de tutor (de zgn. "objectieve" kennismeting) en met behulp van een schaal waarop de tutor zijn eigen deskundigheid aangeeft (de zgn. "subjectieve" schatting). Ten behoeve van de objectieve kennismeting kregen de tutoren voorafgaande aan ieder blok veertig juist-onjuist vragen voorgelegd. Deze items waren geselecteerd uit voortgangstoetsen die de studenten driemaal per jaar moeten invullen. Met behulp van de goed-min-fout score werd vergeleken of de voorkennis van de staf-tutoren verschilde van de student-tutoren. Met behulp van variantieanalyse (ANOVA) werden de verschillen in gemiddelden goed-fout scores berekend. De resultaten van het blok "Rechtshandeling" zijn $F(1,11)=$ $2,02, \mathrm{p}>0,18$. Voor het blok "Onrechtmatig gedrag" zijn de resultaten $F(1,7)$ $=4,05, p<0,05$. Dat betekent dus dat in het blok "Rechtshandeling" geen verschil in kennis geconstateerd werd tussen staf-tutoren en student-tutoren. In het blok "Onrechtmatig gedrag" daarentegen werd wel een significant verschil geconstateerd. Staf-tutoren blijken in het laatstgenoemde blok over meer vakinhoudelijke kennis te beschikken dan student-tutoren. Naast deze objectieve kennismeting werd ook aan de tutoren zelf gevraagd aan te geven in welke mate zij zich meer of minder deskundig achtten met betrekking tot de onderwerpen die in de blokken aan de orde kwamen. Voor deze subjectieve schatting van hun mate van deskundigheid ontvingen alle tutoren in de voorlaatste week van het blok een vragenlijst waarin zij onder andere op een vijfpuntsschaal konden aangeven "in welke mate zij zich deskundig achten op de verschillende onderdelen van het blokboek" (resp. civiel- en bestuursrechtelijk voor het blok "Rechts- 
handeling", en straf- en civielrechtelijk voor het blok "Onrechtmatig gedrag"). Zowel voor de afzonderlijke onderdelen als voor beide onderdelen tesamen werden verschillen tussen gemiddelden getoetst door middel van variantieanalyse (ANOVA). Aangezien de resultaten met betrekking tot de mate van deskundigheid ten aanzien van de verschillende onderdelen afzonderlijk als ten aanzien van het gehele blok niet verschillen, wordt hier volstaan met een weergave van de resultaten van het gehele blok. Voor het blok "Rechtshandeling" werd gevonden $F(1,22)=1,68, \mathrm{p}>0,21$ en voor het blok "Onrechtmatig gedrag" $F(1,16)$ $=0,57, \mathrm{p}>0,46$ Dit betekent dat de stafleden zich in beide blokken niet vakinhoudelijk deskundiger achtten dan de student-assistenten.

In de tweede plaats werd na afloop van het blok aan de studenten de vraag voorgelegd: "de tutor wist (in zeer grote mate - in zeer geringe mate) meer dan wij". De studenten begeleid door student-tutoren scoorden hierop voor blok "Rechtshandeling" (1.3) een gemiddelde van 3,6 en voor het blok "Onrechtmatig gedrag" (1.4) een gemiddelde van 3,4. De studenten begeleid door staf-tutoren scoorden resp. een gemiddelde van 4,0 voor blok 1.3 en 4,2 voor blok 1.4. Verschillen tussen gemiddelden werden getoetst door middel van variantieanalyse (ANOVA). De resultaten daarvan zijn dat de studenten in beide blokken van mening zijn dat de stafleden meer weten dan de student-assistenten $F(1,199)$ $=5,02$, p $<0,05$ voor blok 1.3 en $F(1,149)=0,34, \mathrm{p}<0,001$ voor blok 1.4.

Uit deze gegevens lijkt geconcludeerd te mogen worden dat de studenten wel van mening zijn dat de stafleden over meer kennis beschikken dan de studentassistenten. De docenten zelf vinden dat echter niet. De inschatting van de stafleden kan samenhangen met het feit dat de groep stafleden zeer heterogeen was samengesteld $\mathrm{nl}$. bestaande uit vakinhoudelijke specialisten en meta-juridisch geschoolden (bv. een rechtshistoricus, rechtssocioloog en een onderwijskundige). Vooral deze niet-vakinhoudelijke docenten stelden zich bescheiden op wat betreft hun inschatting van vakinhoudelijke deskundigheid met betrekking tot de verschillende blokonderdelen.

De data verzameld in het blok "Rechtshandeling" ondersteunen de hypothese dat studentgeleide groepen compenseren door harder te studeren. Studentgeleide groepen besteedden gemiddeld meer tijd aan zelfstudie voor de activiteiten van de onderwijsgroep. In het blok "Onrechtmatig gedrag" werden echter geen verschillen gevonden in de hoeveelheid tijd besteed aan zelfstudie voor de onderwijsgroep. Wanneer de studietijdbesteding van de studenten begeleid door stafof student-tutoren over beide blokken tesamen vergeleken wordt, dan blijken de studenten begeleid door student-tutoren ook significant meer tijd te besteden aan zelfstudie ten behoeve van de onderwijsgroep $F(1,280=4,51 ; \mathrm{p}<0,05)$. Hoewel er dus sprake kan zijn van een compensatie-effect bij studenten begeleid door student-tutoren, is dit effect niet overduidelijk in beide blokken aanwezig. Welke andere verklaringen kunnen dan gegeven worden voor de gevonden resultaten? 
Een mogelijke verklaring voor het significante verschil in het blok "Rechtshandeling" zou kunnen zijn dat de studenten begeleid door de student-tutoren meer tijd nodig hebben, bv. omdat hun voorkennis geringer is dan de studenten begeleid door de staf-tutoren, om de leerstof aangeboden in dit blok te verwerken. Dit lijkt echter onwaarschijnlijk. De voorkennismeting voorafgaande aan dit blok leverde geen verschillen op tussen beide condities. Ook de gegevens weergegeven in Tabel 4 duiden erop dat de studenten niet meer tijd besteden aan de andere curriculumonderdelen waarvoor zelfstudie vereist is. Weliswaar worden de leerprestaties van het practicum niet getoetst, voor het college "Rechtsgeschiedenis" is dat wel het geval. Daar werden geen verschillen in leerprestaties tussen beide groepen gevonden. Een andere verklaring, nl. dat de studenten in het blok "Rechtshandeling" voor het eerst in aanraking komen met studenttutoren en dat dit een stimulerend effect heeft op hun studiegedrag, is ook onwaarschijnlijk. Al tijdens het tweede blok treden student-assistenten op als tutor, terwijl ze tijdens het eerste blok van het eerste studiejaar, regelmatig deze onderwijsrol, begeleid door een staflid, oefenen.

Een derde verklaring zou kunnen zijn dat de student-tutoren zich tegenover studenten op een andere wijze gedragen; waardoor deze studenten tot dezelfde leerprestaties komen. Ook de student-tutoren zijn zich bewust van hun relatief geringere vakinhoudelijke expertise en didactische ervaring ten opzichte van de stafleden. Dit besef zou hen kunnen stimuleren om op een andere wijze de begeleiding van de studenten in hun onderwijsgroepen vorm te geven dan stafleden-tutoren doen. Deze veronderstelling wordt in het volgende hoofdstuk nader onderzocht. 


\title{
Verschillen in optreden tussen student- tutoren en staf-tutoren
}

\author{
Resultaten van de observatielijst \\ "tutorgedrag"
}

\section{Inleiding}

In beide vorige hoofdstukken zijn mogelijke effecten van de tutor op het leerproces van de studenten besproken. In Hoofdstuk 4 werd verondersteld dat studenten begeleid door staf-tutoren betere leerprestaties zouden behalen dan studenten begeleid door student-tutoren. Stafleden mogen immers verondersteld worden te beschikken over een relatief grotere deskundigheid en verwacht mocht worden dat dit kennisvoordeel tot uitdrukking zou kunnen komen in de prestaties van hun studenten. Deze veronderstelling bleek niet bevestigd te kunnen worden, er werd geen verschil geconstateerd tussen de leerprestaties van studenten begeleid door student-tutoren en studenten begeleid door staf-tutoren.

Als een van de verklaringen voor de afwezigheid van verschillen in leerprestaties werd geopperd dat studenten begeleid door student-tutoren wellicht meer tijd besteden aan hun studie om die veronderstelde relatieve kennisachterstand van hun student-tutor te compenseren. In Hoofdstuk 5 werd deze hypothese onderzocht. Het onderzoek naar feitelijk bestede studietijd toonde aan dat de studenten begeleid door student-tutoren in het blok "Rechtshandeling" inderdaad significant meer tijd besteedden aan zelfstudie. In het daaropvolgende blok, "Onrechtmatig gedrag", werd echter geen verschil in tijd besteed aan zelfstudie geconstateerd. Over beide blokken heen, echter, bleek weer wel dat de studenten begeleid door de student-tutoren significant meer tijd besteedden aan zelfstudie. De veronderstelling, dat studenten begeleid door student-tutoren de veronderstelde relatieve kennisachterstand van hun begeleider compenseren door harder te studeren, heeft dus slechts een beperkte betekenis, omdat het effect in één van beide blokken niet gevonden werd. 
Een andere mogelijke verklaring voor het ontbreken van verschillen in leerprestaties hangt samen met de wijze waarop student-tutoren en staf-tutoren optreden om het leren van studenten in hun onderwijsgroepen te stimuleren. Zijn er wellicht verschillen in het optreden in de onderwijsgroep tussen staf-tutoren en student-tutoren, en zo ja, welke? Men kan daarbij denken aan de mogelijkheid dat student-tutoren beter begrijpen welke problemen de leden van hun onderwijsgroep hebben met het verwerken van de leerstof en dat ze meer vertellen over hun eigen studie-ervaringen met de onderwerpen die in een bepaald blok aan de orde komen. In dit hoofdstuk zal dus aandacht besteed worden aan het feitelijk gedrag van de tutor zoals gepercipieerd door de studenten.

Om na te gaan of student-tutoren hun rol inderdaad op een andere wijze vervullen dan staf-tutoren werd een observatielijst geconstrueerd en afgenomen. In deze lijst zijn allerlei gedragingen opgenomen met betrekking tot het functioneren van tutoren. De observatielijst werd ontwikkeld op basis van verschillende bronnen. In de eerste plaats werd de literatuur over docentgedrag benut. Als tweede bron voor de constructie van de observatielijst werd gebruik gemaakt van observaties in onderwijsgroepen en interviews met studenten en tutoren. Ten derde werd gebruik gemaakt van het, sporadisch beschikbare, onderzoek naar verschillen tussen student- en staf-tutoren.

In dit hoofdstuk zullen achtereenvolgens de volgende onderwerpen besproken worden. Eerst wordt een schets van de tutorrol gegeven. Na een kort overzicht van wat er van een tutor in formele zin verwacht wordt, volgt een beschrijving van verschillende manieren waarop tutoren in de praktijk hun rol vervullen. Vervolgens worden de verwachtingen van studenten en docenten van de tutorrol beschreven. De verschillende componenten die van belang lijken voor het adekwaat uitoefenen van de tutorrol worden daarna omschreven. In de volgende paragraaf worden mogelijke verschillen in het optreden van student- en staf-tutoren behandeld. Dan wordt de constructie van de observatielijst 'tutorgedrag' besproken. Daarna worden de betrouwbaarheid en validiteit van deze observatielijst aan de orde gesteld. Tenslotte worden de resultaten over het tutorgedrag van student-tutoren en staf-tutoren in de blokken "Rechtshandeling" en "Onrechtmatig gedrag" gepresenteerd.

\section{Schets van de tutorrol}

De bijdrage van de tutor aan het leerproces van de studenten in een onderwijsgroep is een afgeleide van de functie van de onderwijsgroep in probleemgestuurd onderwijs.

De primaire functie van de onderwijsgroep is de studenten te helpen met het verwerven en verwerken van leerstof op een zo zelfstandig mogelijke wijze. In de onderwijsgroep worden de studenten in staat gesteld, in eerste instantie, zelf naar voren te brengen wat zij over een bepaald onderwerp weten. 
Al discussiërende ontdekken de leden van een onderwijsgroep dat er leemtes zijn in hun kennis. Studenten richten zich dan, via zelfstudie, op het verwerven van deze kennis. In een volgende bijeenkomst worden de resultaten van de zelfstudie met elkaar uitgewisseld en verbanden tussen leerstof besproken. In de onderwijsgroep staan dus leerprocessen als voorkennisactivatie, elaboratie, organisatie en integratie van informatie centraal (Schmidt, Foster \& Bouhuijs, 1989). Secundair is de onderwijsgroep bedoeld om de studenten gelegenheid te bieden kennis en ervaring op te doen met samenwerkingsvaardigheden en methodische werkprocedures die leren en probleemoplossen effectiever doen verlopen. De leden van een onderwijsgroep moeten bijvoorbeeld zelf zo veel mogelijk planningsactiviteiten met betrekking tot hun studie verrichten, elkaar onderwijzen en zelf de onderwijsgroepsbijeenkomsten voorzitten.

De taak van de tutor nu is de studenten te ondersteunen in een (geleidelijk aan) te ontwikkelen vaardigheid om zelfstandig te leren. De ondersteunende invulling van het leerproces van de student betekent dat de tutor niet in de eerste plaats degene is die informatie aan de studenten overdraagt. De bijdragen van de tutor aan het leerproces van de studenten, bijvoorbeeld de vragen die hij stelt of de uitleg die hij geeft, moeten gericht zijn op het ontwikkelen van een zelfstandige leerhouding van de student. De tutor moet het leerproces van de studenten faciliteren en de studenten stimuleren tot het zelfstandig vervullen van allerlei leerfuncties die het leren bevorderen. Naast bijdragen op inhoudelijk vlak moet de tutor, zonodig, ook bijdragen leveren aan een effectieve methodische taakbehandeling door de onderwijsgroepsleden en het proces van samenwerking tussen de studenten bevorderen en handhaven.

De wijze waarop een tutor zijn faciliterende rol effectief kan vervullen, wordt sterk beïnvloed door de mate van zelfstandigheid van de studenten. Afhankelijk van de mate van zelfstandigheid van de studenten en hun bereidheid om zelf verantwoordelijkheid te dragen voor hun leren kan een tutor bepaalde onderwijsfuncties die vervuld moeten worden om het leren van de studenten mogelijk te maken, overlaten aan leden van de onderwijsgroep.

De Faculteit der Rechtsgeleerdheid verwacht dat de tutor op de volgende wijze zijn rol vorm geeft:

- De tutor geeft er blijk van goed op de hoogte te zijn van de doelstellingen, structuur en achtergronden van het blok waarin hij een onderwijsgroep begeleidt.

- De tutor is alert op het denkproces van de studenten. Hij let erop dat het denken van de studenten (in eerste instantie) meer gericht is op het begrijpen van onderliggende structuren en processen van en binnen het recht dan het oplossen van specifieke casus. De tutor zorgt waar nodig voor het ver- 
breden van de vraagstellingen door de studenten te helpen hun leerdoelen in een context te plaatsen.

- De tutor vraagt waar nodig aandacht voor definiëring en uitleg van juridische begrippen.

- De tutor moedigt het formuleren van ideeën, verklaringen, hypothesen en interpretaties door studenten aan. Hij vraagt hen--als ze dat niet zelf doen-voortdurend naar hun argumenten; dringt aan op het geven van voorbeelden en bevordert de evaluatie van ideeën, hypotheses en interpretaties.

- De tutor diagnostiseert het cognitieve proces dat in en tussen studenten plaats vindt. Hij probeert zich een beeld te vormen van de (voor)kennis waarover de studenten beschikken. Hij luistert zowel naar de inhoud als intentie van de bijdragen van de studenten.

- De tutor let op de inhoudelijke continuiiteit en richting van de discussie in de groep door ervoor te zorgen dat er regelmatig wordt samengevat en geëvalueerd, teneinde vorderingen en tekortkomingen in de studie zichtbaar te maken (Onderwijskundige uitgangspunten, 1987).

In de dagelijkse praktijk van het onderwijs kunnen enkele uiteenlopende patronen van tutoroptreden geobserveerd worden. Sommige tutoren stellen zich sterk terughoudend op. Ze lijken "zelfwerkzaamheid" en "zelfverantwoordelijkheid" van de student te interpreteren als afwezigheid van participatie van de docent aan datgene wat gebeurt in de onderwijsgroep. "Studentgericht leren" lijkt voor hen te betekenen dat ze zich in absolute zin non-directief moeten opstellen. Aan het andere einde van het spectrum bevinden zich tutoren die zich zeer verregaand met de discussie bemoeien. Deze tutoren stimuleren over het algemeen tot diepgaande discussies. Daarbij stellen ze echter zelf zo vaak en zo veel vragen en geven ze zo veelvuldig uitleg, dat dat ten koste gaat van de interactie tussen de studenten. Weer andere tutoren lijken pas actief te worden wanneer hun eigen vakgebied aan de orde komt. $\mathrm{Ze}$ grenzen hun deskundigheid duidelijk af. Wanneer hun vakgebied niet aan de orde is houden ze zich veelal op de achtergrond. Andere tutoren, tenslotte, vervullen alleen activiteiten gericht op het groepsproces. Hun bijdragen zijn voomamelijk gericht op de wijze waarop de studenten samenwerken en de daarbij behorende procedures (Moust, Bakker \& Nuy, 1989; Wolleswinkel, 1989).

Docenten die de tutorrol vervullen geven dus op verschillende wijze vorm aan deze onderwijstaak. Lucero, Jackson \& Galey (1986) stellen dat het gewenste tutorgedrag sterk bepaald wordt door de manier van werken van de studenten in een onderwijsgroep. De tutor kan hier vorm aangeven door voorbeeldgedrag te vertonen:

"A skilled tutor must be a role model for students in such areas as quantity and quality of work, critical thinking, tutorial democracy, and enthusiasm and growth. The tutor should stimulate a high level of 
expectation and performance and facilitate the assumption of leadership skills by the group members" (Lucaro, et al. p. 53).

Moust, Bouhuijs en Schmidt (1989) zijn van mening dat de wijze waarop tutoren deze rol vervullen samen lijkt te hangen met de verschillende visies van de tutoren op (probleemgestuurd) leren en onderwijzen, hun vaardigheden in het verzorgen van onderwijs en vakinhoudelijke deskundigheden. De wijze waarop een tutor zijn tutorrol vervult, respectievelijk kan uitoefenen, wordt in sterke mate bepaald door de ideeën die de tutor zelf en zijn studenten hebben van de wijze waarop de tutor zijn taken zou moeten uitvoeren. We gaan op die ideeën hieronder nader in.

\section{Verwachtingen van studenten en tutoren van de tutorrol}

In de bovenstaande paragraaf werd beschreven op welke wijze tutoren, afhankelijk van de mate van zelfstandigheid van de studenten, onderwijsgroepen zouden moeten begeleiden. In deze paragraaf wordt aandacht besteed aan de wijze waarop tutoren hun begeleidingsactiviteiten in de praktijk feitelijk verrichten. De manier waarop docenten hun onderwijstaak vervullen lijkt in sterke mate bepaald te worden door de verwachtingen en overtuigingen die docenten en studenten hebben over de wijze waarop er in de leeromgeving geleerd kan worden (Clark \& Peterson, 1986; Wittrock, 1986). Onderwijzen en leren zijn interactieve, wederkerige processen waarbij verwachtingen van elkaars bijdragen een sterke rol spelen bij de wijze waarop studenten en docenten zich inzetten.

Om te achterhalen welke verwachtingen studenten en tutoren hebben van de tutorrol zijn studenten en tutoren geïnterviewd. Tweedejaars studenten werden uitgenodigd deel te nemen aan een interview over hun ervaringen in het eerstejaars onderwijs. Ze werden uitvoerig ondervraagd over hun ervaringen met tutoren in het algemeen en met staf- en student-tutoren in het bijzonder. Dertien studenten reageerden op deze uitnodiging.

Tutoren werden tijdens de blokken "Inleiding in het nederlands recht" en "Overheid" eenmaal per week tijdens onderwijsgroepsbijeenkomsten geobserveerd en na afloop van iedere bijeenkomst geïnterviewd over hun verwachtingen van de tutorrol en hun ervaringen met het begeleiden van onderwijsgroepsbijeenkomsten.

Tijdens de onderwijsblokken "Rechtshandeling" en "Onrechtmatig gedrag" werden nogmaals respectievelijk 19 en 12 aselect gekozen studenten geïnterviewd over de kwaliteit van het onderwijs tijdens de onderwijsperiode. Alle interviews werden op band opgenomen en schriftelijk uitgewerkt. Eerst worden de verwachtingen van studenten en stafleden met betrekking tot de tutorrol besproken. Eventuele verschillen tussen student-tutoren en staf-tutoren zullen verderop in dit hoofdstuk ter sprake komen. 
De verwachtingen van de studenten met betrekking tot de activiteiten die een tutor in een onderwijsgroep moet uitoefenen, lijken sterk bepaald te worden door de mate waarin de studenten al min-of-meer zelfstandig kunnen studeren. Sommige studenten hebben nog behoefte aan een flinke mate van directieve sturing door de tutor, andere studenten vinden het plezierig wanneer de tutor zich meer begeleidend opstelt. Enkele studenten beschreven hun verwachtingen als volgt:

"Ik vind het plezierig wanneer je gericht kunt werken. Soms laten tutoren je wat te veel zwemmen. Ze geven dan ongeveer aan wat je moet weten of wat belangrijk is. Maar als je andere signalen oppikt, zou dat voor jou net zo relevant kunnen zijn, omdat ze je niet echt verwijzen naar wat relevant is voor een toets of zo. ... Het meest stimulerend vind ik wanneer een tutor enthousiasme toont, laat zien dat hij er zich echt in verdiept heeft. Dat hij de stof leuk vindt en laat blijken dat hij er interesse in heeft die stof aan ons over te brengen. Dat hij laat merken dat je met iets waardevols, iets belangrijks bezig bent. ... De meerwaarde van de tutor is dat hij de structuur in de stof aangeeft, omdat je zelf de stof nooit zo goed kan uitdiepen. Je weet immers nog niet waar nou echt op gelet moet worden, wat nou echt belangrijk is. Het minst stimulerend is dan ook wanneer tutoren je wat laten aanmodderen." (student 0.01 )

"Wat mij helpt om de stof beter te begrijpen, is wanneer er duidelijke vragen gesteld worden in de onderwijsgroep. ... Een tutor dus die veel vragen stelt, niet de antwoorden geeft maar stelt 'Ja maar, heb je het al eens zo bekeken'. Dat vind ik heel belangrijk. Dus niet iemand die er maar wat bij zit, en als de groep helemaal verkeerd gaat, ingrijpt met 'Nee, je moet je alleen maar daar en daar mee bezig houden. Ik vind dat de tutor vragen moet stellen die de stof concreet maken. En dat mis ik wel eens. Dat gebeurt niet zo veel. Tutoren die je actief laten nadenken. ... In het eerste jaar mis je vooral de vaardigheid om jezelf vragen te stellen. Kijk, je zoekt de leerstof op en je bent blij als je iets gevonden hebt. Dan wordt het voorgelezen, maar verder wordt er dan niet gekeken of je het begrijpt of je er wel zelf iets mee kunt doen." (student 0.02)

"De tutor moet weten waar het eigenlijk over gaat. Die moet de zaken die bij het blok horen, jurisprudentie en artikelen, eigenlijk kennen. We moeten zelf de leerdoelen formuleren, maar literatuur vinden is nog altijd moeilijk. Je hebt dan wel verschillende boeken, maar iets uit de NJB of Ars Aequi halen, dat blijft moeilijk. Daar kan een tutor je mee helpen." (student 0.03)

"Voor mij is hun aanwezigheid heel belangrijk. Ook dat ze laten merken dat ze er zijn. Niet constant het woord doen, ze moeten ons onze gang wel laten gaan, maar als het misgaat, moeten ze gewoon ingrijpen. En als er bepaalde dingen zijn waarvan ze gewoon voelen dat is belangrijk, en wij daar een beetje te vluchtig over heen gaan, dat ze dan gewoon zeggen 'Stop, leg dat nog eens uit' of 'Hoe zit dit of dat in mekaar, noem eens een voorbeeld'. De tutor moet je af en toe een bepaaide richting opsturen of je bepaalde dingen uitleggen, want het is lang niet altijd begrijpelijk wat in boeken staat. Ik denk dat het dan ook heel belangrijk is dat ze er op zo'n moment ook een heleboel van afweten of, in ieder geval, dat ze zelf de leerstof behandeld hebben." (student 0.04)

"Meest zinvolle gedrag van de tutor: tutoren die veel vragen stellen, waardoor je kunt nagaan of je het wel allemaal begrijpt. Waardoor je ook zelf vragen kunt stellen. Daardoor ging ik de stof dan beter begrijpen." (student 0.05 ) 
"De tutor heeft invloed, je studie kan door hem veel gerichter zijn. Ik bedoel als je in een groep een leerdoel maakt zonder medewerking van cen tutor, kan 't heel vaag zijn. De essentiële punten komen dan niet helemaal naar voren. Terwijl als een tutor dan zijn mening kenbaar maakt dan kan het veel gerichter zijn. Dat bespaart je een heleboel tijd. Maar er zijn ook tutoren die zeggen achteraf: 'Tja, jongens, jullie hadden eigenlijk dit moeten bestuderen'. Dat vind ik vreselijk. Dan kun je de stof nog eens gaan doen, dat vind ik heel vervelend. Belangrijk voor een student is dat de tutor stuurt, zegt welke dingen in de stof belangrijk zijn, en welke niet. De tutor moet de essentiële onderwerpen aanduiden. Dat stimuleert mij tot veel meer studeren. Ik heb het liefst een tutor die erop wijst wat belangrijk is in de stof, dat hij de gespreksleider helpt, dat hij heel duidelijk aanwezig is." (student 0.10 )

"Als het een goeie tutor is, dan gaat het het hele blok door dat zij de accenten aangeven van 'dit is nou belangrijk, en dit is niet belangrijk'. Want je kan soms in een taak zo hopeloos verwikkeld raken in allerlei dingen die je erbij betrekt, dat een goede tutor je dan de hoofdzaken, wat nou eigenlijk belangrijk is, moet aangeven." (student 0.13 )

\section{Naast een verschillende behoefte aan inhoudelijke sturing door de tutor, bena- drukken de studenten ook dat een tutor zich goed moet kunnen inleven in het kennisnivo van de studenten.}

"Er komen wel eens leerdoelen naar boven die misschien in de ogen van een tutor wel heel simpel zijn, maar die door ons gewoon uitgezocht moeten worden. De tutor wil dan gewoon dieper in die stof doorgaan, terwijl je er zelf nog niet helemaal aan toe bent. Want je hebt de basis niet. Maar hij vindt het dan zo belangrijk dat dat diepere aan de orde komt. En dan komt het aan de orde, maar dan mis je het gewoon. Dan sla je gewoon de plank mis. Je weet dan wel wat, maar dat zijn dan losse stukken. Daar weet je iets van af, en daar, en daar. Maar wat het allemaal met elkaar te maken heeft, dat begrijp je dan niet. ... Wat ik zo verschrikkelijk vind zijn die tutoren die beginnen met ' $\mathrm{k}$ ben tutor en hoef jullie dus eigenlijk niets voor te zeggen. Ja, discussieer maar'. Dat is het ergste wat je mee kunt maken. Ten eerste klap ik dan dicht. Want zo iemand weet heel veel en jij weet bijna niets van wat er behandeld wordt. Je hebt vragen. En hij of zij maakt wel uit of die relevant zijn. Maar de gedachtengang daarover krijg je helemaal niet mee. Daar wordt gewoon niet op ingegaan. En dan vraag je iets wat misschien heel basaal is, voor meerdere mensen in de groep, en dan reageren ze zo met 'Ja maar, dat behoor je toch eigenlijk al te weten!' Dan ga ik dus volkomen de mist in, dan durf ik dus niets meer te vragen. Dan denk ik 'dat zal wel zo'n domme vraag zijn, laat maar zitten.' En als dat vaker voorkomt dan hoeft de studie voor mij ook niet meer. Zulke tutoren houden zich echt strikt aan hun rol, zo van 'wij moeten een beetje leiden, maar verder moeten jullie het maar allemaal zelf doen'." (student 0.02)

"Verschrikkelijk is de tutor die stelt: 'Ik begrijp niet dat jullie dat niet begrijpen' dan voel je je op een gegeven moment heel stom. Dan denk je 'waarom begrijpen we dat dan niet?'." (student $0.04)$

Tevens verwachten de studenten dat een tutor dicht bij de studenten staat. Een tutor moet interesse, betrokkenheid tonen voor het leren van de studenten. Enkele geïnterviewden daarover:

"Ik vind dat de tutoren dicht bij jou en bij de stof moeten staan. En zich niet moeten gedragen als DE TUTOR. Omdat dat een afstand schept, die er niet zou moeten zijn. Dat werkt op mij heel remmend. Het heeft op mij een absoluut averechtse werking wanneer iemand tegen mij zegt: 'dat mag ik niet zeggen', of eh, 'het is niet aan mij om jou wat te vertellen'. Ik voel dat als een 
afwijzing. Dan heb ik zoiets van: 'ik kan toch ook aan iemand uit de groep vragen om het te vertellen, en dan vertelt ie het wel'. Dan denk ik 'nou, zo iemand zit er toch ook bij om een stukje stimulans door te geven, om wanneer je op een dood punt zit je op te krikken zodat je verder kan gaan'. En daarom denk ik dat de tutor heel dicht bij de stof moet staan en ook bij de student." (student 0.05)

"Meest bevorderlijk is oprechte interesse van de tutor. Ik zit niet hier omdat het moet, maar uit interesse. Vooral een echte discussie met de groep werkt zeer stimulerend op mij. Negatief werkt een tutor die zich formeel opstelt, die afstandelijk blijft. ... We hebben eens een tutor gehad die, wanneer we fouten maakten, steeds zei: 'Ja, dat moeten jullie nog maar eens uitzoeken'. Dat zijn geen sturende en stimulerende vragen. Hij deed dat tot het arrogante toe. Dat is beslist niet motiverend. Het moest juist zijn, wanneer het fout ging zei hij alleen dat het anders moest. Zonder zichzelf in te zetten." (student 0.09)

"Ik verwacht dat de tutoren zelf hun zaken goed hebben voorbereid. Ook moeten de tutoren heel actief zijn, ze moeten zich in wisselwerking met ons actief opstellen. Ze moeten bezorgdheid, betrokkenheid tonen. Niet de hoeveelheid bijdragen is belangrijk, maar de betrokkenheid van de tutor. Tutoren die echt met de stof bezig zijn, die de taken zelf hebben doorgekeken, die zelf de leerdoelen nog eens hebben uitgezocht, de structuur van het blok beheersen. Belemmerend voor het leren vind ik tutoren die er zich gemakkelijk vanaf maken: 'Nou ja, dat is wel goed zo, dat hebben we wel voldoende behandeld', terwijl jezelf het gevoel hebt dat je het nog niet goed begrijpt. Tutoren die afdempen, zich laks opstellen ten opzichte van de groep." (student 0.13 )

\section{Verwachtingen van docenten van de tutorrol}

\section{Tutoren lijken zelf ook sterk de spanningsboog te ervaren tussen zelf sturen van het leerproces en de studenten de gelegenheid bieden om zelf actief vorm te geven aan hun leren. Ze denken op verschillende wijze over de mate waar- in ze studenten in een onderwijsgroep actief moeten bijstaan.}

\footnotetext{
"Ik vind een eerstejaarsgroep altijd heel moeilijk en vermoeiend. ... Dat komt voomamelijk ook omdat je rol niet duidelijk is en de verwachtingen van de groep ten aanzien van de tutor uiterst vaag zijn. ... Ik heb zoiets van je moet ze stimuleren, dus als je altijd maar 'nee, ik weet het niet, dat moet je zelf uitzoeken' roept, kan dat demotiverend werken. Het is ontzettend moeilijk. ... Als ik het gevoel heb dat ze veel gestudeerd hebben en hun best hebben gedaan om iets uit te zoeken, maar er op detailpunten niet uitkomen, dan ben ik geneigd om ze daar inderdaad mee uit de droom te helpen, als ik het weet. Maar ik zeg ook met graagte dat ik het niet weet. Dan komen ze erachter dat een tutor ook geen alwetende machine is, een kast waar je een laatje van kunt opentrekken. Dat idee moeten ze ook niet krijgen. ... Het is voortdurend bij iedere groep weer een uitdaging. ... Maar studenten hebben ook behoefte aan zekerheid. Aan hoe je bepaalde moeilijke dingen kunt onthouden. Daar zijn leuke ezelsbruggetjes voor. Dan heb ik zelf de neiging om die te vertellen op een gegeven moment. Ik denk ook dat dat leuk is. Ik heb ze zelf vanuit mijn studietijd onthouden. Daar kom je verder mee. Dan stap ik af van het traditionele tutoridee. ... Af en toe heb ik het idee dat je een duizendpoot moet zijn. ... Ik probeer heel veel te doen door het stellen van vragen. $l k$ vind het altijd zo moeilijk, want als je heel veel vragen stelt, dan trek je daarmee de aandacht als tutor naar jezelf toe. Dat is heel vervelend. Maar soms denk ik toch 'dat moet ik toch maar doen om te weten of ze het nou echt begrepen hebben'. Want het blijkt voor veel studenten heel moeilijk te zijn om de rapportage zo te doen dat je als tutor ook het idee hebt van 'ze hebben de kempunten goed gesnapt'." (docent 01)
} 
"In het algemeen verloopt het te oppervlakkig. De studenten zijn gauw tevreden. Iemand dic icts niet wil zeggen hoeft dat niet. Dat vind ik niet prettig, maar als zij dat willen. ... De groep stelt normen ten opzichte van ieders inbreng, die ik te laag vind. ... De tutor heeft een horzelfunctie. Studenten moeten kritisch leren lezen en nadenken. Maar die horzelfunctie heeft ook nadelen. Studenten vinden het helemaal niet plezierig wanneer je hen als tutor wilt laten zien dat het niet allemaal zo gemakkelijk ligt als het zich voordoet. ... Voor hen is reproduceren belangrijk, niet redeneren. Ik verwacht geen oogst op dat gebied. ... Het blijft allemaal te oppervlakkig. ... Als tutor zit je in de vervelende positie dat je vragen gaat stellen wanneer er niemand meer behoefte heeft dat er vragen gesteld gaan worden. Je komt dan al gauw in de omstandigheid dat je alleen maar een negatieve inbreng hebt. In de zin van 'dat is nog niet aan de orde geweest' of 'gaan we op deze manier niet hieraan voorbij', etc. ... Plaatsen van de leerstof in een zinvol verband lukt niet, bijvoorbeeld waarom je de ene vraag eerder stelt dan een andere. Ik leg het dus maar gewoon uit. ... Ik heb er twijfels over of wij de studenten hier oefenen in het gebruiken van hun verstand. Wellicht willen die achttienjarigen die onzekerheden ook niet. Je moet als tutor de kwaliteit bewaken. Maar ze lezen niet, raggen overal door, werken niet. Er is niets verteerd. ... Ze moeten leren knoeien op de vierkante millimeter." (docent 02)

"Wanneer je als tutor ook nog eens als gespreksleider gaat functioneren en je dus erg actief bent, zijn de studenten zeer alert op wat je doet. Ze schrijven alleen dat op wat jij opschrijft. Je bent niet zomaar iemand. In de dubbelrol gespreksleider en tutor is het erg moeilijk om te vermijden dat je niet dominant bent in de groep. Te meer daar jouw woorden dan een extra gewicht hebben. ... In de startfase van een onderwijsgroep wordt elk woord wat je als gespreksleider of tutor zegt op een goudschaaltje gewogen. ... Zo gauw ik een zin hoor, waarvan ik denk 'die komt uit een boekje', vraag ik door. 'Geef daar maar eens een voorbeeld van', 'waarom denk je dat' of 'zeg dat maar eens in je eigen woorden'. ... Ik vind het belangrijk dat ze de relativiteit en de achtergronden weten. Gros van de studenten vindt dat hinderlijk, wilt iets afgebakend hebben. Alsof ze behoefte hebben aan 'weten dat je de som kent', de stap verder, het kenmerk van een wetenschappelijke opleiding, daar zijn ze huiverig voor. Leren is voor hen zekerheid krijgen. Terwijl complicaties zien, dat lukt niet altijd. ... Niet de mate van bijdrage van de tutor vinden de studenten bepalend, maar zijn belangstellende houding. Studenten zoeken veiligheid, zekerheid. Een garantie dat ze het goed doen. ... Zo'n groep is natuurlijk ook erg kwetsbaar. Je geeft je als student bloot. Je moet als tutor aardig zijn: persoonlijk, relativerend, soms vermanend." (docent 03)

"Ik vind het mijn taak de studenten de rode draad in het blok te laten zien, anders gaan ze de mist in. Een tutor moet bijsturen als er een controverse is tussen twee subgroepen en bij een oppervlakkige taakanalyse. Als de taken (uit het blokboek, JM) niet helder zijn, moet je de leerdoelen beïnvloeden, ze bijsturen in een bepaalde richting. ... Het handelen van de tutor wordt bepaald door de tijdsfactor en de inbreng van de studenten. ... Ik heb af-en-toe wat vragen gesteld die in het tutorboek stonden. Dat moet je so-wie-so doen. Ze verwijzen nogal gemakkelijk naar één boek. Daarom stel ik een aantal vragen, om te kijken of ze het begrepen hebben. Ik vind dat het reproduceren van de bestudeerde stof in de onderwijsgroep vaak moeizaam verloopt. Uit eigen beweging doen de studenten dat nauwelijks. Ik verwijs ook regelmatig naar de inleiding van het blokboek, waar ze bepaalde zaken terug kunnen vinden, waardoor ze de stof in een bepaald kader kunnen plaatsen. ... Wil je toch zorgen, vooral als maar een deel van de groep gestudeerd heeft, dat er wat kwaliteit naar boven komt dan moet je zelf het heft in handen nemen. ... Ik ben niet iemand die dan denkt 'stik maar'. Je hebt een stuk verantwoordelijkheid voor wat er in zo'n groep omgaat. ... Ik vind wel dat het mijn taak is om te zorgen dat belangrijke punten, leerstukken uit zo'n blokboektaak naar boven komen. Of dat nou door hun zelfstandig naar voren wordt gebracht of desnoods door mij. Ik vind het wel van belang dat dat gebeurt, maar om ze nou ter verantwoording te roepen, wat ze hebben gedaan of waarom ze niets hebben gedaan, nee dat is mijn taak niet..." (docent 04) 
"Ik vind de sfeer heel belangrijk ... Ze in ieder geval als persoon aanspreken. ... Ik denk dat ik heel erg op de methode gericht ben: leren samenwerken en leren leren. ... Ik ben ervan overtuigd dat als het proces goed loopt, de inhoud ook goed aan de orde komt. Je kunt dan beter je verantwoordelijkheden overgeven." (docent 05)

"Ik denk dat het een belangrijke taak van de tutor is om de studenten op te zwepen. Je kunt dat doen door prikkelende vragen te stellen." (docent 07)

\section{Kenmerken van tutoroptreden}

Uitgaande van de formele omschrijving van de tutorrol, de verwachtingen van de studenten en docenten over de wijze waarop een tutor zijn rol moet uitoefenen en de wijze waarop tutoren en studenten feitelijk vorm geven aan het probleemgestuurde leerproces in de dagelijkse praktijk van de onderwijsgroep, worden onderstaand de kenmerken van de tutorrol geschetst die de basis vormen voor de observatielijst 'tutoroptreden'.

In de tutorrol zijn twee hoofdcomponenten te onderscheiden: de wijze waarop studenten en tutor omgaan met de kennis die verworven moet worden en de wijze waarop zij een relatie met elkaar opbouwen. Deze twee hoofdcomponenten worden achtereenvolgens uitgewerkt.

\section{De kenniscomponent}

Tutoren en studenten benadrukken dat de tutor over vakinhoudelijke kennis moet beschikken betreffende het thema dat in het onderwijsblok aan de orde komt. De tutor moet, op een bepaald niveau, deskundig zijn op de leerstofgebieden die in het onderwijsblok aan de orde komen en overzicht hebben over de verschillende onderwerpen die in het blokboek aangereikt worden. Aan de inhoudelijke bijdragen van de tutor wordt door de studenten waarde gehecht. Kennis van zaken hebben is echter niet voldoende. Leren is, zoals al meerdere malen is opgemerkt, een activiteit die in sterke mate bevorderd wordt door een actieve inbreng van de student in het leerproces. De wijze waarop een tutor gebruik maakt van zijn kennis om actief leren van de studenten te bevorderen, speelt derhalve een belangrijk rol voor het (zelfgestuurde) leerproces van de studenten. Aan de wijze waarop een tutor gebruik maakt van zijn kennis lijken verschillende aspecten te zitten. Ten eerste, lijkt de wijze waarop een tutor gebruik maakt van zijn vakinhoudelijke deskundigheid een sterke invloed te hebben op het leergedrag van de groepsleden. Zowel wanneer tutoren zich te actief als wanneer zij zich te passief opstellen met betrekking tot het overdragen van informatie aan de studenten, lijkt het zelfstandig leren van de studenten belemmerd te worden. Tutoren moeten de mate waarin ze hun kennis in de onderwijsgroep inbrengen blijkbaar goed kunnen doseren. Uit de interviews komt naar voren dat tutoren met hun kennis heel verschillend omgaan. Sommige tutoren trekken zich vrijwel 
geheel terug uit het leerproces van de studenten onder de noemer dat de student zelf actief moet zijn. Ze laten teveel aan de studenten over. De studenten krijgen daardoor het gevoel dat ze aan hun lot worden overgelaten, dat ze te veel en te lang 'zwemmen'. Andere tutoren nemen voortdurend het voortouw en laten de studenten te weinig ruimte tot eigen initiatief. Deze tutoren corrigeren te snel en te veelvuldig verkeerde opvattingen van studenten zonder de studenten enige ruimte te bieden om zelf correcties toe te passen. Ze benadrukken dat bepaalde onderwerpen zeker bestudeerd moeten worden of adviseren de studenten met enige nadruk bepaalde onderwerpen nu niet te bestuderen en te bespreken. Ze zijn zo actief tijdens de onderwijsgroepsbijeenkomsten dat ze de studenten tot passiviteit dwingen. De zelfstandigheid van de studenten lijkt het sterkst bevorderd te worden door tutoren die, vooral via vragen en korte toelichtingen, geleidelijk aan de groepsleden stimuleren tot het zelfstandig onderzoeken van de onderwerpen die in de blokboeken aangedragen worden. De mate waarin tutoren over vakinhoudelijke kennis beschikken en van hun vakinhoudelijke kennis gebruik maken om het zelfstandig leerproces van de onderwijsgroepsleden te bevorderen wordt in deze studie voortaan aangeduid met de omschrijving "gebruik van expertise".

In de tweede plaats lijkt het leren van studenten beïnvloed te worden door de wijze waarop tutoren hun kennis ten dienste stellen van de onderwijsgroepsleden. De studenten benadrukken in de interviews dat hun leren vooral gestimuleerd wordt wanneer een tutor zich kan verplaatsen in hun denkwereld en in de problemen die zij hebben om de leerstof te begrijpen. De tutor moet als het ware kunnen "afdalen" tot het denkniveau van de studenten. Hij moet zich kunnen inleven in de wijze waarop de studenten de nieuwe leerstof verwerken en zich een beeld kunnen vormen van de manieren waarop de studenten hun kennis organiseren en bewerken. Wanneer een tutor vragen stelt en uitleg geeft moet hij zijn bijdragen in begrijpelijke termen kunnen gieten. Hij moet voorbeelden, schema's, ezelsbruggetjes geven die de studenten helpen greep te krijgen op de leerstof en die hen in staat stellen de leerstof beter te onthouden. Sommige tutoren lijken goed in staat te zijn studenten te helpen door bijvoorbeeld concrete voorbeelden, analogieën en metaforen aan te bieden die de studenten helpen met het organiseren van hun kennisstructuur. Andere tutoren lijken verder af te staan van de denkwereld van de student. Hun bijdragen worden door de studenten als te abstract ervaren, de student kan zich maar weinig voorstellen bij datgene wat de tutor te berde brengt. Cornwall (1980) en Ten Cate, Tromp en Cornwall (1984) duiden het vermogen van een onderwijsgevende om zich in te leven in het kennisbestand van de onderwijsontvangenden aan met het begrip "cognitieve congruentie". We zullen in deze studie dit begrip verder gebruiken om het inlevingsvermogen in de denkwereld van de student aan te geven. 
In de Faculteit der Rechtsgeleerdheid vervult de bloktoets, die aan het einde van een onderwijsblok wordt afgenomen, een summatieve functie. Dit betekent dat de resultaten van de toets meetellen in beslissingen omtrent slagen of zakken van de student. Hoewel veel studenten en docenten onderkennen dat de uiteindelijke doelstelling van het juridisch onderwijs het zelfstandig kunnen oplossen van juridische problemen is, zijn beide partijen zich ook bewust van het gegeven dat aan het einde van iedere blokperiode een toets met een voldoende resultaat moet worden afgelegd. Studenten en tutoren lijken in hun handelen beïnvloed te worden door de waarde die ze hechten aan het product dat de uitkomst moet zijn van al de leeractiviteiten binnen en buiten de onderwijsgroep. Veel studenten richten hun studieinspanningen op het behalen van de toets. Ze studeren toetsgericht. En een deel van hun activiteiten in de onderwijsgroep is er op gericht te achterhalen of bepaalde onderwerpen die in de onderwijsgroep aan de orde komen deel zullen uitmaken van de bloktoets. Ze proberen op directe of indirecte wijze bij de tutor na te gaan of deze hen mogelijkerwijze indicaties kan geven over wat er op de bloktoets gevraagd kan worden. Tutoren lijken ook rekening te houden met het summatieve karakter van de bloktoets. Ze tonen zich bijvoorbeeld nadrukkelijk bezorgd over de mate van diepgang waarin studenten de leerstof soms verwerken en stellen eisen aan de hoeveelheid leerstof die zij moeten bestuderen. Ook lijken sommigen de toets te gebruiken om studenten te motiveren tot harder werken door te verwijzen naar bijvoorbeeld de zwaarte van de bloktoets, de zak- of slaagcijfers in voorgaande jaren of door verwijzing naar mogelijke onderwerpen die deel uit kunnen maken van de bloktoets. In deze studie zal de gerichtheid van de tutor op de bloktoets verder aangeduid worden met het begrip "toetsoriëntatie".

\section{De relatiecomponent}

De primaire doelstelling van een onderwijsgroep is het verwerven van kennis. Een onderwijsgroep is echter ook een sociaal systeem waarin de deelnemers relaties met elkaar opbouwen. De tutor is onderdeel van het relatienetwerk in een onderwijsgroep. Uit de interviews komt naar voren dat tutoren zich nogal verschillend opstellen. Sommige tutoren gaan op een tamelijk afstandelijke en formele wijze om met de leden van hun onderwijsgroep. Ze proberen een bepaalde controle uit te oefenen op de wijze waarop in de onderwijsgroep gewerkt wordt. Ze willen in sterke mate de wijze bepalen waarop de interactie in de onderwijsgroep verloopt. Tijdens de eerste bijeenkomst geeft de tutor aan wat de studenten van hem mogen verwachten aan inhoudelijke inbreng. De tutor is sterk vakgericht en controleert nauwkeurig de juistheid van informatie die de studenten inbrengen. Wanneer de groepsleden over onvoldoende of incorrecte informatie beschikken zal de tutor ze eerder terecht wijzen dan stimuleren. De studenten hebben moeite om toe te geven dat ze bepaalde on- 
derdelen niet weten of begrijpen omdat ze bang zijn voor kleinerende of sarcastische opmerkingen van de tutor. Wanneer de tutor iets uitlegt of de inbreng van studenten bekritiseert laat hij vaak, via non-verbaal gedrag, blijken dat aan zijn mening niet getwijfeld hoeft te worden. In deze studie zal een formele opstelling van de tutor verder worden aangeduid met het begrip "autoriteit".

Andere tutoren daarentegen stellen zich meer open op naar de studenten. Ze houden meer rekening met de behoeften van de studenten. Ze kunnen zich goed de problemen voorstellen die eerstejaarsstudenten tegenkomen tijdens hun studie en hun studentenleven. Ze laten blijken dat ze waardering hebben voor de wijze waarop studenten hun informatie vergaren en verwerken. Ze moedigen studenten aan door hen te vertellen dat ze "op de goede weg zijn" of door ook iets te vertellen over hun eigen studie-ervaringen. Deze tutoren laten blijken dat ze informeel contact met de tutoren plezierig lijken te vinden. In deze studie zal het vermogen van de tutor om zich in te leven in de leefwereld van de student aangeduid worden met het begrip "rolcongruentie".

Een van de taakaspecten van de tutorrol, tenslotte, is het begeleiden van het proces van samenwerking tussen de studenten in de onderwijsgroep. Van de tutor mag verwacht worden dat hij een zekere aandacht besteedt aan de wijze waarop de studentgespreksleider de onderwijsgroepsbijeenkomsten leidt en dat hij oog heeft voor de wijze waarop studenten samenwerken. Wanneer de samenwerking niet adekwaat verloopt, en de inhoudelijke verwerking van de leerstof hierdoor minder optimaal is, dient de tutor de samenwerking te evalueren en de studenten adviezen te verstrekken hoe zij hun onderlinge activiteiten beter op elkaar kunnen afstemmen. In deze studie zal dit aspect van de tutorrol verder aangeduid worden met het begrip "aandacht voor samenwerking".

\section{Mogelijke verschillen tussen student-tutoren en staf-tutoren; een eerste verkenning}

In de volgende paragrafen wordt een beschrijving gegeven van mogelijke verschillen in de manieren waarop student- en staf-tutoren deze rol lijken te vervullen. Op basis van theoretische overwegingen, observaties in onderwijsgroepen en bestaand onderzoek worden mogelijke verschillen tussen student- en staf-tutoren nader uitgewerkt. De suggesties dragen een tentatief karakter. 


\section{Verschillen in de mate waarin student-tutoren en staf-tutoren hun expertise gebruiken}

Aangenomen mag worden dat staf-tutoren over meer kennis beschikken met betrekking tot de onderwerpen die in de cursussen aan de orde komen dan student-tutoren. ${ }^{1}$ De student-tutoren zijn studenten die slechts twee of drie jaar verder met hun studie zijn dan de studenten die zij begeleiden. De staftutoren zijn daarentegen leden van de wetenschappelijke staf die vaak na hun studie in een of meer juridische beroepen hun kennis hebben kunnen uitbouwen en toepassen. Zij hebben zich op een bepaald juridisch gebied gespecialiseerd en verrichten naast hun onderwijstaken onderzoek naar bepaalde onderdelen binnen hun specialisatie. Als experts binnen een juridisch vakdomein zullen stafleden beschikken over meer systematische strategieën voor de analyse en oplossing van juridische problemen dan ouderejaarsstudenten. Het kennisbestand van staf-tutoren en student-tutoren zal derhalve verschillen, niet alleen in inhoud maar ook in organisatie. De kennis van stafleden zal uitgebreider en meer gedetailleerd zijn dan de kennisstructuur van de studentassistenten. De kennis van stafleden zal ook een grotere coherentie vertonen en stafleden zullen waarschijnlijk ook meer in staat zijn hun kennis flexibel te gebruiken. Men mag aannemen dat de staf-tutoren als gevolg van hun meer gedifferentieerde kennisnetwerk een beter overzicht hebben over en inzicht in de leerstof die in een blokboek aan de orde komt dan student-tutoren.

Verondersteld wordt eveneens dat staf-tutoren, doordat ze meer weten van de onderwerpen die aan de orde komen, eerder dan student-tutoren in het leerproces van de onderwijsgroepsleden zullen ingrijpen. Staf-tutoren lijken, meer dan student-tutoren, bezorgd dat de studenten te weinig leerstof behandelen, zich niet bewust zijn dat ze afdwalen en niet veel inzicht hebben in het niveau waarop ze de leerstof moeten doorgronden. Door hun meer gedifferentieerde kennisstructuur zullen de staf-tutoren waarschijnlijk sneller dan de student-assistenten in de gaten hebben dat studenten op de verkeerde weg zijn. $\mathrm{Zij}$ lijken, op basis van hun expertise, eerder en beter te kunnen anticiperen welke vakinhoudelijke misverstanden ontstaan of gehandhaafd blijven wanneer de studenten op de 'verkeerd' ingeslagen weg doorgaan. Staf-tutoren lijken, wanneer ze waanemen dat onderwijsgroepsleden op onvolledige of onjuiste wijze informatie uitwisselen, sterker dan student-tutoren geneigd het besprokene direct te corrigeren in plaats van enige tijd af te wachten of de groepsleden zelf onduidelijkheden, incoherenties of onvolledigheden in hun argumentaties ontdekken.

'Alhoewel we met de resultaten van een kennismeting onder student- en docent-tutoren niet in staat waren in een van de blokken de nulhypothese te verwerpen gaan we er hier gemakshalve van uit dat dat te wijten was aan een gebrek aan sensitiviteit van het instrument. Studenten zelf beoordeelden staf-tutoren als beschikkend over meer kennis dan student-tutoren. 
Uit een onderzoek in de Faculteit der Geneeskunde naar de wijze waarop stafleden hun tutorrol beleven (Moust, De Grave \& Gijselaers, 1990), bleek dat hun belangrijkste probleem was de wijze waarop zij hun vakinhoudelijke deskundigheid tijdens de discussies in de onderwijsgroep konden inbrengen. Hoewel veel van de facultaire medewerkers een positieve mening hadden over de functie van de onderwijsgroep in probleemgestuurd onderwijs, had slechts een klein deel van de ondervraagden een positieve opvatting over de tutorrol. Veel stafleden beschreven de tutorrol als "that passive role, sitting back in my chair, following silently a discussion between students, only intervening when something is going wrong" (p. 148). De respondenten spraken sterk de wens uit als docent meer zichtbaar te zijn. Ze wilden door de studenten gezien worden als vakbekwame docenten en wetenschappers. Ook in discussies over het onderwijs in de faculteit der Rechtsgeleerdheid werd door medewerkers herhaaldelijk opgemerkt dat de tutorrol een sterkere inhoudelijke accentuering behoeft. "Ik zou graag meer begrip en waardering willen vragen voor de persoon die meent dat hij het aan zijn vakgebied verschuldigd is het niet al te zeer te laten verminken," aldus de reactie van een docent (OC-86-I-52) op een facultaire nota waarin gepleit werd overmatige inhoudelijke sturing door tutoren te beperken (OC.86051/ II).

Student-tutoren lijken minder moeite te hebben met de faciliterende bijdrage die van een tutor verwacht wordt. Ze hebben immers zelf enkele jaren deelgenomen aan probleemgestuurd onderwijs. Zij zijn vertrouwd geraakt met een onderwijsvorm waarin studenten onderling de leerstof bediscussiëren en actief bezig zijn met het verwerven en verwerken van de leerstof. Ze hebben aan den lijve ondervonden dat onderlinge bijdragen van medestudenten invloed hebben op de organisatie en herorganisatie van hun kennis. Ze hebben als groepslid in meerdere onderwijsgroepen gefunctioneerd en zijn daardoor in aanraking gekomen met de verschillende manieren waarop staf-tutoren het leerproces begeleiden. Ze hebben de invloed van bijvoorbeeld een inhoudelijk actief sturende tutor tegenover een inhoudelijk actief stimulerende tutor op hun eigen leerproces meegemaakt. Hieruit hebben ze zich enigermate een beeld kunnen vormen van wenselijke en minder wenselijke interventies van de tutor met betrekking tot het bevorderen van de zelfwerkzaamheid van studenten in een onderwijsgroep.

Uit het sporadische onderzoek dat al eerder gedaan is naar mogelijke verschillen in optreden tussen student-tutoren en staf-tutoren lijkt het beeld van een meer actieve staflid-tutor ook naar voren te komen. Uit onderzoek van De Grave, De Volder, Gijselaers en Damoiseaux (1986) bleek dat het gedrag van staf-tutoren en student-tutoren in de ogen van de door hen begeleide studenten vooral verschilde op de volgende punten. De staf-tutoren "leken vaker een duidelijker beeld te hebben van de doelen van het desbetreffende blok", "legden onderwerpen meer op eigen initiatief uit", "observeerden nauwgezetter het interactieproces in hun onderwijsgroep", "activeerden stu- 
denten sterker de leerstof uit te diepen" en "namen vaker de rol van gespreksleider op zich." De student-tutoren daarentegen "leken vaker belangstelling te wekken voor de onderwerpen die aan bod kwamen", "evalueerden de bijeenkomsten regelmatiger", "deden meer mee alsof zij zelf groepslid waren", "toonden betrokkenheid met het functioneren van de groep" en "leken beter te voldoen aan het (ideale) beeld van de tutorrol." Naar aanleiding van deze verschillen in tutorgedrag merken De Grave et al. op dat de genoemde verschillen suggereren dat een staflid zich meer gedraagt als een "subject-matterexpert-on-top-of-things" en dat een student meer handelt als een collega dan als een superieur (p 7). Smith, Feletti en Hughes (1986) onderzochten, binnen het probleemgestuurde curriculum van de Faculteit der Geneeskunde in de University of Newcastle te Australië, in een onderwijsblok de wijze waarop derdejaarsstudenten eerstejaarsstudenten begeleidden in onderwijsgroepen. De studenten oordeelden positief over de inhoudelijke expertise van hun studenttutoren: zij hadden voldoende kennis van de doeleinden van de onderwijsgroepsbijeenkomsten, van de onderwerpen die in het blok ter discussie voorlagen, van de structuur van de cursus, van de regelingen en de toetsvereisten. Minder tevreden waren de studenten over het vermogen van de student-tutoren om hen te laten reflekteren over hun wetenschappelijke voortgang, hen verantwoordelijkheid te laten dragen voor hun eigen leren en het vermogen om alle studenten van de onderwijsgroep te betrekken bij het probleemoplossingsproces. In een vergelijking tussen deze evaluatie-resultaten en de waardering van studenten van staf-tutoren die drie jaar eerder in hetzelfde onderwijsblok onderwijsgroepen begeleid hadden, bleek dat de stafleden de studenten meer gelegenheden boden zelfstandig de problemen te onderzoeken en op te lossen en dat deze stafleden de studenten actief betrokken bij het evalueren van hun wetenschappelijke voortgang. De student-tutoren werden iets beter beoordeeld wat betreft het ontwikkelen van een faciliterend leerklimaat: zij gaven de studenten meer gelegenheid zich vrijelijk te uiten, ze begrepen de problemen van de studenten beter en moedigden hen meer aan zelfstandig te denken.

\section{Verschillen in de mate waarin student-tutoren en staf-tutoren zich kunnen verplaatsen in de denkwereld van de student}

Uitgaande van de aanname dat stafleden over een grotere en meer gedifferentieerde kennisstructuur beschikken met betrekking tot de onderwerpen die in de blokken aan de orde komen, wordt verondersteld dat de kennisstructuur van de student-tutoren waarschijnlijk meer zal lijken op die van de studenten die zij begeleiden. Cornwall (1980) en Ten Cate, Tromp en Cornwall (1984) beschouwen deze "cognitieve congruentie" als een van de belangrijkste theoretische verklaringen voor het feit dat er vaak geen verschillen geconstateerd worden in onderzoek naar student- en docentgeleid onderwijs (zie voor een 
uitgebreide toelichting Hoofdstuk 2). Doordat de kennisstructuur van ouderejaarsstudenten meer in overeenstemming is met het kennisbestand van de jongerejaars, zal volgens genoemde auteurs de student-docent waarschijnlijk beter in staat zijn zich te verplaatsen in de inhoudelijke problemen die jongerejaars tegenkomen bij de bestudering van de leerstof. De student-docent heeft immers soortgelijke problemen met de leerstofverwerking nog relatief kortgeleden persoonlijk of in zijn onderwijsgroep ervaren. Student-docenten lijken zich dan ook beter te kunnen verplaatsen in de inhoudelijke problemen die de studenten tijdens het bestuderen van de leerstof tegen zullen komen. Ze zullen zich waarschijnlijk gemakkelijker een beeld kunnen vormen van de moeilijkheden die jongerejaars met de leerstof hebben. Naast een beter en sneller begrip van de problemen die studenten tegenkomen bij het verwerken van de nieuwe informatie, zullen de bijdragen van de student-tutor aan het leerproces van de studenten als gevolg van deze cognitieve congruentie tussen student-docent en studenten waarschijnlijk ook op zulk een wijze verwoord worden, dat ze voor de studenten gemakkelijker te begrijpen zijn. Ten Cate, Tromp en Cornwall (1984) merken hierover op:

"Als de docent een medestudent is, zal zijn uitleg waarschijnlijk ongeveer op hetzelfde kennisniveau plaatsvinden als waarop zijn studiegenoten zich bevinden. Hij zal waarschijnlijk slechts gebruik maken van begrippen en relaties die zij reeds kennen. Hij zal ook dezelfde "taal" gebruiken. De deskundige docent daarentegen kan niet meer dan proberen zich in te leven in de student, met andere woorden zich in cognitieve zin in diens positie te verplaatsen en zich beperken tot de veronderstelde aanknopingspunten tussen bestaande en nieuwe kennis. Zelfs de beste docent zal dit niet altijd goed gelukken. Een docerende student heeft weinig keus, van het te doceren onderwerp weet hij maar een beetje" ( $p$. 90).

De student-tutor zal wellicht in zijn communicatie met studenten vaker een eenvoudiger woordkeus gebruiken dan stafleden. Hierdoor slaagt hij er waarschijnlijk beter in bepaalde onderwerpen op een eenvoudige wijze uit te leggen en zullen de vragen die hij aan de leden van de onderwijsgroep stelt misschien begrijpelijker zijn.

\section{Verschillen in de mate waarin student-tutoren en staf-tutoren gericht zijn op de toets}

Hoewel tutoren geen deel uitmaken van de commissie die de toetsvragen samenstelt, hebben zij, bijvoorbeeld op grond van eerdere tutorervaringen in een onderwijsblok of omdat ze als student vroeger ook een soortgelijke bloktoets zelf beantwoord hebben, vaak wel enig idee van de onderwerpen die deel zouden kunnen uitmaken van de toetsvragen die aan de studenten worden voorgelegd. 
Verondersteld wordt dat de student-tutoren in hun begeleidingsactiviteiten in de onderwijsgroep sterker gericht zullen zijn op de bloktoets dan de staftuturen. Student-tutoren hebben immers onlangs zelf de bloktoets moeten beantwoorden en kunnen zich beter dan staf-tutoren het belang van het behalen van de bloktoets voorstellen. Ze kunnen zich beter dan staf-tutoren voorstellen wat het voor een student betekent wanneer hij een onvoldoende beoordeling behaalt voor de toets.

Student-tutoren lijken de bloktoets bovendien vaker te gebruiken als een instrument om de leden van hun onderwijsgroepen te motiveren. Ze lijken er zich sterk van bewust te zijn dat de studenten slechts een beperkte tijd hebben om zich vaak toch tamelijk gecompliceerde onderwerpen eigen te maken. Wanneer rapportages halfslachtig verlopen, studenten weinig tijd besteden aan hun studie of uitstelgedrag vertonen, sporen ze de studenten aan tot harder studeren door expliciet te verwijzen naar de zak-/slaagcijfers op de bloktoets in voorgaande studiejaren. Ook door aan te duiden dat bepaalde onderwerpen mogelijkerwijze deel uit zouden kunnen maken van de toetsing proberen ze studenten aan te zetten tot harder studeren. Ze lijken studenten meer dan staftutoren te verwijzen naar de informatie en literatuuropgaven zoals deze in het tutorboek opgenoemd staan.

\section{Verschillen in de mate waarin student-tutoren en staf-tutoren hun autoriteit uitoefenen}

Student-tutoren en docent-tutoren lijken ook te verschillen in de wijze waarop ze zichzelf zien als degenen die verantwoordelijk zijn voor de gang van zaken in de onderwijsgroep. Verondersteld wordt dat de staf-tutoren eerder en vaker, onder verwijzing naar de schriftelijke instructies die tutoren krijgen met betrekking tot de inhoud van het blokboek, bepalen welke informatie in de onderwijsgroep relevant is of niet. Staf-tutoren lijken sneller aan te geven op welke onderwerpen de groep beter wel of niet door kan gaan. Ze vellen, verbaal of non-verbaal, vaker een oordeel over welke informatie wel of niet acceptabel is. Wanneer studenten bepaalde onderwerpen niet vlug genoeg begrijpen, maken ze soms spottende opmerkingen over de inbreng van de groepsleden. Studenten lijken daardoor bij staf-tutoren meer moeite te hebben om toe te geven dat ze iets niet begrijpen omdat ze het gevoel hebben dat ze daarvoor "bestraft" worden. Staf-tutoren nemen eerder beslissingen, bijvoorbeeld over de leerdoelen die uitgezocht moeten worden, zonder daar met de studenten gezamenlijk over te beslissen. Op een enigszins schoolmeesterachtige wijze bepalen staf-tutoren soms de gang van zaken in de onderwijsgroep. 
Verschillen in de mate waarin student-tutoren en staf-tutoren zich kunnen verplaatsen in de leefwereld van de studenten

Aangenomen wordt dat de student-tutoren zich in het algemeen, op grond van gedeelde ervaringen, beter dan staf-tutoren zullen kunnen inleven in de problemen, moeilijkheden en mogelijkheden van eerstejaarsstudenten binnen de context van probleemgestuurd leren. De student-tutoren hebben immers het curriculum zelf recentelijk doorlopen. Ze hebben ongeveer dezelfde leeftijd als de studenten die ze begeleiden en delen de studentencultuur. Studenttutoren weten uit persoonlijke ervaring wat het is om als onderwijsgroepslid onderwijsgroepsbijeenkomsten bij te wonen die soms goed, soms slecht verlopen. Ze kunnen zich voorstellen hoe een gespreksleider zich voelt wanneer hij een moeizaam verlopende discussie draaiende moet houden. Ze hebben vaker meegemaakt hoe frustrerend het kan zijn naar literatuur te moeten zoeken die niet gevonden wordt. Ze hebben ontdekt dat met bepaalde leerdoelen niet of onvoldoende zelfstandig verder gewerkt kan worden. Ze kunnen zich beter voorstellen dat studenten niet goed kunnen inschatten hoe diepgaand of hoe breed ze de stof moeten bestuderen. Ook zullen ze zich gemakkelijker een beeld kunnen vormen van en belangstelling hebben voor de manier waarop eerstejaarsstudenten hun universitaire studie beleven.

Aannemende dat student-docenten beter de 'valkuilen' van probleemgestuurd onderwijs begreep, zullen ze gemakkelijker dan de staf-tutoren de specifieke studieproblemen van de leden van de onderwijsgroep begrijpen en meer dan stafleden geneigd zijn te vertellen hoe zij met soortgelijke studieproblemen zijn omgegaan. Ze zullen sneller dan staf-tutoren laten blijken dat ze de inspanningen van de groepsleden om de leerstof op te sporen en te verwerken waarderen. Door hun relatief gelijke leeftijd en studentenachtergrond zullen ze in het algemeen ook gemakkelijker dan staf-tutoren in staat zijn informele contacten te leggen met studenten. Door meer persoonlijke genegenheid, betrokkenheid en waardering te tonen voor de studie-inspanningen van de onderwijsgroepsleden, sluiten de student-tutoren directer aan bij de behoeften van de groepsleden dan de staf-tutoren.

\section{Verschillen in de mate waarin student-tutoren en staf-tutoren aandacht hebben voor de samenwerking in de onderwijsgroep}

Tijdens elke onderwijsgroepsbijeenkomst wordt van de studenten verwacht dat zij op een zelfstandige wijze met elkaar aan de taken werken die hen via het blokboek worden aangereikt. Tijdens de bijeenkomst is een van de groepsleden gespreksleider. Van de tutor wordt verwacht dat hij periodiek aandacht besteedt aan het functioneren van de onderwijsgroep en de gespreksleider. Tutoren kunnen dat doen door tijdens het verloop van de bijeenkomst en tijdens de evaluatie adviezen te verstrekken hoe de groep op een 
meer eflectieve en efficiënte wijze haar doelen kan bereiken. Aangenomen wordt dat student-tutoren meer aandacht zullen besteden aan de samenwerking in de onderwijsgroep dan staf-tutoren. De student-tutoren zijn immers tijdens hun opleiding in de juridische studie in deze faculteit meer vertrouwd geraakt met onderwijs in kleine groepen dan de stafleden. Deze laatsten komen veelal uit juridische opleidingen waar kleinschalig groepsonderwijs als didactische werkvorm nog relatief onbekend is. De student-tutoren hebben tijdens hun studie waarschijnlijk veel frequenter persoonlijk ervaren dat goed functioneren van de onderwijsgroep en gespreksleider een positieve bijdrage levert aan de inhoudelijke verwerking van de leerstof.

Samengevat worden de volgende verschillen tussen student-tutoren en staftutoren verwacht:

- staf-tutoren bezitten meer vakinhoudelijke kennis over de leerstof dan student-tutoren; bovendien gaan staf-tutoren minder terughoudend om met hun vakinhoudelijke deskundigheid dan student-tutoren. Ze grijpen meer in de discussie in en zien er op toe dat de studenten meer aandacht besteden aan verbanden tussen de leerstof en het toepassen van de leerstof op praktijkvoorbeelden;

- student-tutoren zijn beter in staat zich in te leven in de problemen die studenten hebben met de leerstof dan staf-tutoren;

- student-tutoren zijn meer gericht op het eindprodukt van het leren: het behalen van de bloktoets;

- staf-tutoren oefenen meer autoriteit uit ten opzichte van de studenten dan student-tutoren;

- student-tutoren zijn beter in staat zich in te leven in de leefwereld van de studenten dan staf-tutoren;

- student-tutoren hebben meer aandacht voor het samenwerken van de onderwijsgroepsleden en het functioneren van de tutor.

\section{Betrouwbaarheid en validiteit van de observatielijst "tutorge- drag"}

\section{Methode}

In deze paragraaf zullen eerst vorm en inhoud van de observatielijst "tutorgedrag" beschreven worden. Vervolgens wordt verslag gedaan van pogingen de onderliggende structuur van de observatielijst te onderzoeken. Tenslotte zullen betrouwbaarheids- en validiteitsgegevens gepresenteerd worden.

\section{Instrument}

De observatielijst "tutorgedrag" is een (quasi-)observatieinstrument waarmee studenten een samenvattend oordeel over het gedrag van hun tutor geven (en 
over hun eigen reacties op dat gedrag). De observatielijst heeft een diagnostisch doel: nagaan of student-tutoren anders optreden in onderwijsgroepen dan staf-tutoren. De studenten waaraan de observatielijst werd voorgelegd moeten dan ook niet beschouwd worden als 'evaluators' van tutorgedrag maar als 'reporters of events' van tutoroptreden (McBean \& Al-Nassri, 1982).

De items opgenomen in de observatielijst bevatten een bewering over het gedrag van de tutor. Aan dit gedrag kunnen twee kenmerken onderscheiden worden: de sterkte waarmee het gedrag voorkomt, ofwel de intensiteit van het gedrag; en het aantal keren dat het gedrag voorkomt, ofwel de frequentie van het gedrag.

De intensiteit werd gemeten via een schaal die loopt van: 'in zeer geringe mate' (1), 'in geringe mate' (2), 'soms wel / soms niet'(3), 'in grote mate' (4) tot 'in zeer grote mate' (5). Aan de studenten werden bijvoorbeeld de volgende items voorgelegd:

"De tutor toonde (in zeer geringe mate, etc.) betrokkenheid bij onze studie".

"De bijdragen van de tutor hielpen mij (in zeer geringe mate, etc.) verbanden te zien tussen stukjes leerstof".

"Door het optreden van mijn tutor had ik (in zeer geringe mate, etc.) moeite toe te geven dat ik iets niet begreep."

De frequentie werd gemeten via een schaal die loopt van 'nooit' (1), 'zelden' (2) 'regelmatig' (3) 'vaak' (4) tot 'altijd' (5).

Enige voorbeelden van items die de frequentie waarin het gedrag optreedt meten zijn:

"De tutor liet (nooit, etc.) weten dat hij van een bepaald onderwerp slecht op de hoogte was."

"De tutor gebruikte (nooit, etc.) dezelfde terminologie als wij."

De observatielijst 'tutorgedrag' bestond uit 46 items. De items uit de observatielijst hadden betrekking op de hierboven beschreven kenmerken van tutoren. Ieder kenmerk bestond uit een aantal items. In de observatielijst werden zowel positief als negatief geformuleerde items opgenomen. De items waren beschrijvend van aard.

Onderstaand zijn de verschillende kenmerken en een aantal items per kenmerk aangeduid. Voor sommige criteriumgedragingen werd gekozen voor de frequentie van het gedrag, voor andere criteriumgedragingen voor de intensi- 
teit waarmee de tutor het gedrag vertoonde. Voor een volledige weergave van de observatielijst "tutorgedrag" wordt verwezen naar Bijlage 6.1. ${ }^{2}$

\section{Gebruik van expertise}

10. De bijdragen van de tutor hielpen mij ... verbanden te zien tussen stukjes leerstof.

28. De tutor had ... overzicht over de leerstof.

\section{Cognitieve congruentie}

09. De tutor kon zich ... verplaatsen in de inhoudelijke problemen die wij tijdens dit blok tegenkwamen.

35. De tutor stelde ... begrijpelijke vragen.

\section{Toetsoriëntatie}

37. De tutor waarschuwde ... voor de zwaarte van dit blok.

45. De tutor verwees ... naar de zak-/slaagcijfers van dit blok in het vorige studiejaar.

\section{Autoriteit}

38. De tutor maakte ... kleinerende opmerkingen wanneer wij bij de bespreking van een onderwerp 'de plank missloegen'.

51. De tutor liet ... merken dat zijn mening de enig juiste was.

\section{Rolcongruentie}

13. De tutor toonde ... waardering voor ons werk.

21. De tutor had ... begrip voor de problemen die een eerstejaars heeft met zijn studie.

\section{Aandacht voor samenwerking}

55. De tutor had ... aandacht voor het functioneren van de onderwijsgroep.

57. De tutor evalueerde ... de groepsbijeenkomsten.

Naast vragen die op de bovenvernoemde kenmerken betrekking hadden, zijn ook nog meer algemene vragen gesteld die probeerden te inventariseren hoe groot, naar schatting van de studenten, de invloed van hun tutor op hun leren geweest was en de mate waarin de studenten zich onzeker voelden bij een tutor. $\mathrm{Zij}$ blijven hier op grond van psychometrische kenmerken verder buiten beschouwing.

${ }^{2}$ Om te vermijden dat de studenten te zeer gericht waren op het functioneren van de tutor, werd de observatielijst "tutorgedrag" opgenomen in een vragenlijst waarin de studenten ook gevraagd werd een oordeel te geven over allerlei andere aspecten van het onderwijs in de betreffende blokperiode, bijvoorbeeld het functioneren van de onderwijsgroep, de kwaliteit van het blokboek en van de colleges en practica. Bijlage 6.1 geeft de gehele vragenlijst weer.

${ }^{3}$ De interne consistentie van deze subschalen bleek zeer laag. 


\section{Procfpersonen}

De observatielijst 'tutorgedrag' werd voorgelegd aan alle studenten in de laatste blokweek van de onderwijsblokken "Rechtshandeling" en "Onrechtmatig gedrag".

256 Studenten in het blok "Rechtshandeling" en 188 studenten in het blok "Onrechtmatig gedrag" vulden de vragenlijst in.

\section{Procedure}

Tijdens de laatste practicumbijeenkomst werd door de practicumdocent aan de studenten gevraagd de observatielijst 'tutorgedrag' in te vullen. De observatielijst was een onderdeel van een grotere vragenlijst waarmee het gehele onderwijs gedurende het onderwijsblok door de student geëvalueerd werd. Naast de tutorgedragitems vulden de studenten ook vragen in met betrekking tot het functioneren van de onderwijsgroep, het practicum, de colleges en de kwaliteit van het blokboek in.

\section{Meetkenmerken van het instrument}

Bij de verwerking van de observatielijst is naast de itemscores steeds gebruik gemaakt van de daaruit berekende schaalscores. De som van de itemscores per subschaal werd omgezet in schaalscores variërend van 1,0 tot 5,0 met behulp van een lineaire transformatie. Uit de metingen met het instrument kunnen enkele conclusies over de betrouwbaarheid en de validiteit worden getrokken.

Om de betrouwbaarheid van het instrument te berekenen werd de interne consistentie van de schalen in beide onderwijsblokken onderzocht. Tabel 6.1 geeft een overzicht van de alpha's van de verschillende kenmerken van tutoroptreden.

Tabel 6.1

Homogeniteitsindex van de kenmerken van de observatielijst "tutorgedrag" in de onderwijsblokken "Rechtshandeling" (1.3) ( $n=256)$ en "Onrechtmatig gedrag" (1.4) ( $n=188)$

Schaal

Blok 1.3

Blok 1.4

Gebruik van expertise

Cognitieve congruentie

Toetsoriëntatie

Autoriteit

Rolcongruentie

Aandacht voor samenwerking
0,83

0,69

0,49

0.67

0,66

0,59
0,85

0,71

0.31

0.65

0,75

0,65 
We kunnen constateren dat de betrouwbaarheid van de verschillende schalen van de observatielijst "tutorgedrag", afgemeten aan de interne consistentie van de subschalen, boven of net rond de 0.60 ligt.

De coëfficiënt alpha is, zoals gezegd, een homogeniteitsindex. Hij geeft de gemiddelde correlatie tussen items binnen een schaal en negeert andere bronnen van variantie. Een methode die wèl alle mogelijke variantiebronnen betrekt bij de vraag hoe betrouwbaar - feitelijk hoe generaliseerbaar - een meting is, is de generaliseerbaarheidstheorie van Cronbach, Gleser, Nanda \& Rajaratnam (1972). Onderzocht werd in hoeverre over de items en de beoordelaars gegeneraliseerd kan worden naar andere groepen items en personen.

De volgende procedure werd gevolgd. Allereerst werd het aantal onderwijsgroepen dat begeleid werd door een student-tutor dan wel een staflidtutor gelijkgesteld (door aselecte verwijdering van enkele onderwijsgroepen). Vervolgens werd van elke onderwijsgroep onderzocht hoeveel personen de observatielijst 'tutorgedrag' hadden ingevuld. Het aantal respondenten bleek te variëren van 5 tot 11 per onderwijsgroep, met een gemiddelde van 8 personen. Om een gebalanceerd design te krijgen werd besloten de gegevens van 5 aselect gekozen leden per onderwijsgroep te gebruiken. Vijf studenten spreken daarbij een "oordeel" over een tutor uit. Voor het blok "Rechtshandeling" werden in totaal 24 onderwijsgroepen, respectievelijk begeleid door 12 student-tutoren en 12 staf-tutoren geselecteerd. In totaal konden zo de gegevens van 120 studenten worden geanalyseerd. Voor het blok "Onrechtmatig gedrag", waarin eenzelfde procedure werd gevolgd, betrof de analyse 18 onderwijsgroepen, respectievelijk begeleid door 9 student-tutoren en 9 staf-tutoren. Bij deze generaliseerbaarheidstudie waren derhalve 90 studenten betrokken.

De volgende facetten werden in het design opgenomen: variantie tussen tutoren (T), variantie tussen items (I), variantie van studenten genest binnen tutoren (S:T), variantie van tutoren interacterend met items (TI) en variantie van items interacterend met studenten genest binnen tutoren (IS:T). Volgens Shavelson \& Webb (1991) is hier sprake van een gedeeltelijk genest design met 2 facetten, nl. tutoren en items. Om de generaliseerbaarheidscoëfficiënt van de verschillende kenmerken van tutoroptreden na te gaan werd gebruik gemaakt van de volgende formule:

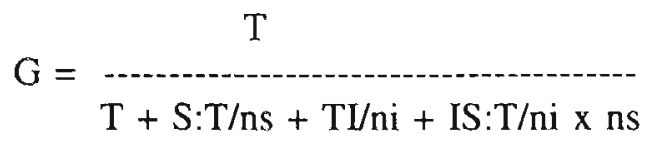

Vervolgens zijn volgens de normale procedures met behulp van de GENOVA software (Brennan, 1983) voor de verschillende bronnen van variantie de variantiecomponenten berekend (Zie Bijlage 6.2). In Tabel 6.2 worden de generaliseerbaarheidscoëfficiënten van de verschillende facetten van tutorop- 
treden weergeven die voortvloeien uit de G(eneraliseerbaarheids)-studie en D(ecisie)-studie (Shavelson \& Webb, 1991). In deze D-studie wordt onderzocht uit hoeveel, in dit geval, beoordelaars een onderwijsgroep moet bestaan wil er sprake zijn van een hoge generalisatie van de resultaten van het onderzoek naar andere onderzoekspopulaties. In de kolommen 2 en 5 staat de generaliseerbaarheidscoëfficiënt van het oordeel door 5 beoordelaars (studenten). In de overige kolommen wordt de coëfficiënt weergegeven die de resultante is van de D-studie. In de kolommen 3 en 6 wordt de interbeoordelaarsovereenstemming (uitgedrukt in deze coëfficiënt) weergegeven wanneer 8 studenten (het gemiddeld aantal studenten dat de observatielijst had ingevuld) de tutor beoordelen, in de kolommen 4 en 7 staat de betrouwbaarheid van de afzonderlijke schalen vermeld wanneer 11 studenten (het aantal studenten dat voor de aanvang van iedere blok per onderwijsgroep wordt ingedeeld) de tutor zouden beoordelen.

Uit de gegevens uit tabel 6.2 kan geconcludeerd worden dat de generaliseerbaarheid van de schalen 'Gebruik van expertise', 'Cognitieve congruentie' en 'Rolcongruentie" al bij een klein aantal studenten $(=5)$ redelijk hoog tot hoog is.

\section{Tabel 6.2}

Generaliseerbaarheidscoëfficiënten bij 5, 8 en 11 studenten in de blokken "Rechtshandeling" en "Onrechtmatig gedrag"

Rechtshandeling Onrechtmatig gedrag

Schaal Aantal studenten Aantal studenten

\begin{tabular}{lcccccc}
\hline & 5 & 8 & 11 & 5 & 8 & 11 \\
\cline { 2 - 7 } & & & & & & \\
Gebruik van expertise & 0,91 & 0,93 & 0,94 & 0,86 & 0,88 & 0,89 \\
Cognitieve congruentie & 0,77 & 0,83 & 0,86 & 0,74 & 0,81 & 0,84 \\
Toetsoriëntatie & 0,61 & 0,72 & 0,78 & 0,40 & 0,52 & 0,60 \\
Autoriteit & 0,68 & 0,73 & 0,76 & 0,71 & 0,76 & 0,79 \\
Rolcongruentie & 0,72 & 0,80 & 0,85 & 0,79 & 0,83 & 0,86 \\
Aandacht voor samenwerking & 0,50 & 0,61 & 0,69 & 0,77 & 0,84 & 0,87
\end{tabular}

Wanneer het aantal studenten dat de tutor beoordeelt toeneemt, wordt de generaliseerbaarheid van deze schalen, zonder uitzondering hoog. De schalen 'Toetsoriëntatie', 'Autoriteit' en 'Aandacht voor samenwerking' zijn bij een klein aantal beoordelaars $(=5)$ matig tot redelijk. De gegevens laten echter zien dat, wanneer meer studenten $(=11)$, de observatielijst "tutorgedrag" zou- 
den invullen, op dèe dimensies eveneens hoge generaliseerbaarheidscoëfficiënten behaald kunnen worden.

Om een beeld te krijgen van de constructvaliditeit van de verschillende schalen werd gebruik gemaakt van confirmatorische factoranalyse. De gebruikte schattingstechniek was de "maximum likelihood" benadering met behulp van het programma EQS (Bentler, 1985). Deze toetsende factoranalyse maakt het mogelijk een vooraf gedefinieerde structuur te testen en de mate van passen of "fit" met behulp van de data vast te stellen. De analyse werd uitgevoerd op de variantie-covariantiematrix van de studentgegevens verkregen in het blok "Rechtshandeling" ( $\mathrm{n}=256$ ). Volgens Boomsma (1983) kan confirmatorische factoranalyse pas nuttig toegepast worden bij een $\mathbf{n}$ groter dan $200^{4}$. De resultaten van deze analyse waren: chi-kwadraat $=1004,20$ (bij 449 vrijheidsgraden) $\mathrm{p}<0,001$. De Bentler-Bonnet normed fit index (BB NFI) is 0,66 , de Bentler-Bonnet nonnormed fit index (BB NNFI) is 0,75 en de comparative fit index (CFI) bedraagt 0,78 . Dit betekent dat het model redelijk past bij de data. Een goede fit zou pas verkregen zijn wanneer de waarden voor de BB NFI en BB NNFI boven de 0,90 gelegen zou zijn (Bentler, 1990). Het is niet onwaarschijnlijk dat het feit dat de fit slechts redelijk te noemen is, voortkomt uit het feit dat bij de analyse van de data uitgegaan werd van de veronderstelling dat de resulterende schalen van elkaar onafhankelijk waren. Dit is geen redelijke veronderstelling; zowel in empirische als theoretische zin. Tabel 6.3 laat zien dat enkele dimensies hoog met elkaar correleren. Ook theoretisch is het zeer wel voorstelbaar dat factoren gecorreleerd zijn. Bijvoorbeeld omdat ze elkaar causaal beïnvloeden of omdat ze nu eenmaal gezamenlijk in een bepaalde mate voorkomen (zonder overigens herleidbaar te zijn tot hetzelfde construct).

In Tabel 6.3 wordt de correlatietiematrix van de zes factoren vermeld (gestandaardiseerde oplossing) De subschalen Gebruik van expertise, Cognitieve Congruentie vertonen hoge onderlinge correlaties. De subschaal Autoriteit correleert zwak tot matig negatief met alle andere subschalen. De subschaal Rolcongruentie correleert redelijk positief met de subschaal Cognitieve Congrentie en redelijk negatief met de subschaal Autoriteit, met de andere schalen is er een zwakke positieve correlatie. De subschaal Aandacht voor samenwerking correleert zwak tot matig met de overige subschalen.

+ Het factormodel dat in het blok "Rechtshandeling" werd gevonden, werd ook getoetst op de data van het blok "Onrechtmatig gedrag". Toetsing van het factormodel leverde de volgende "fit": chi-kwadraat $=1167.388$ (bij 449 vrijheidsgraden), $p<0,001$. De BB NFI is $0,6.38$. BB NNFl $=0,709$ en de CFl is 0,736 . Deze resultaten rechtvaardigen de conclusie dat het factormodel 1.3 repliceerbaar is voor het blok "Onrechtmatig gedrag". 


$\begin{array}{llllll}1 & 2 & 3 & 4 & 5 & 6\end{array}$

1. Gebruik van expertise $\quad 1,00$

2. Cognitieve congruentie $\quad 0,69 \quad 1,00$

3. Toetsoriëntatie $\quad 0,30 \quad 0,23 \quad 1,00$

4. Autoriteit $\begin{array}{lllll}0,03 & -0,41 & -0,07 & 1,00\end{array}$

5. Rolcongruentie $\quad 0,33 \quad 0,68 \quad 0,21 \quad-0,58 \quad 1,00$

6. Aandacht voor samenwerking $\begin{array}{llllll}0,31 & 0,42 & 0,27 & -0,20 & 0,49 & 1,00\end{array}$

\section{Verschillen in tutorgedrag tussen student-tutoren en staf- tutoren in het blok "Rechtshandeling" en "Onrechtmatig gedrag"}

\section{Methode}

\section{Proefpersonen}

In het blok "Rechtshandeling" werden 242 studenten begeleid door een student-tutor of een staflid-tutor. Hiervan vulden 202 studenten de vragenlijst in. In het blok "Onrechtmatig gedrag" werden 207 studenten begeleid door een student-tutor of een staflid-tutor. Hiervan vulden 150 studenten de vragenlijst in.

\section{Procedure}

Verschillen tussen student-tutoren en staf-tutoren op de verschillende schalen werden getoetst door middel van variantie-analyse (ANOVA).

\section{Resultaten}

De Tabellen 6.4 en 6.5 laten de gemiddelden, standaardafwijkingen en significantieniveaus zien van de afname van de observatielijst "tutorgedrag" in het blok "Rechtshandeling" en het blok "Onrechtmatig gedrag". Hoe hoger de gemiddelde score, hoe meer de betreffende groep het kenmerk bezit. 
Tabel 6.4

Gemiddelden, standaardafwijkingen en significantieniveaus in het blok "Rechtshandeling"

\begin{tabular}{|c|c|c|c|c|c|}
\hline Schaal & Conditie & Gemiddelde & SD & $\begin{array}{l}\text { F geob- } \\
\text { serveerd }\end{array}$ & $\begin{array}{l}\text { p geob- } \\
\text { serveerd }\end{array}$ \\
\hline $\begin{array}{l}\text { Gebruik van } \\
\text { expertise }\end{array}$ & $\begin{array}{lr}\text { student-tutoren } & 96 \\
\text { staf-tutoren } & 106\end{array}$ & $\begin{array}{l}3,1 \\
3,1\end{array}$ & $\begin{array}{l}0,4 \\
0,5\end{array}$ & 1,41 & 0,24 \\
\hline $\begin{array}{l}\text { Congnitieve } \\
\text { congruentic }\end{array}$ & $\begin{array}{lr}\text { student-tutoren } & 96 \\
\text { staf-tutoren } & 106\end{array}$ & $\begin{array}{l}3,7 \\
3,4\end{array}$ & $\begin{array}{l}0,4 \\
0,6\end{array}$ & 17,00 & 0,001 \\
\hline Toutsoriëntatie & $\begin{array}{lr}\text { student-tutoren } & 96 \\
\text { staf-tutoren } & 106\end{array}$ & $\begin{array}{l}2,5 \\
2,3\end{array}$ & $\begin{array}{l}0,5 \\
0,8\end{array}$ & 8,06 & 0,005 \\
\hline Autoriteit & $\begin{array}{lr}\text { student-tutoren } & 96 \\
\text { staf-tutoren } & 106\end{array}$ & $\begin{array}{l}1,7 \\
1,8\end{array}$ & $\begin{array}{l}0,6 \\
0,7\end{array}$ & 4,05 & 0,05 \\
\hline Rolcongruentie & $\begin{array}{lr}\text { student-tutoren } & 96 \\
\text { staf-tutoren } & 106\end{array}$ & $\begin{array}{l}3,0 \\
2,6\end{array}$ & $\begin{array}{l}0,6 \\
0,6\end{array}$ & 23,34 & 0,001 \\
\hline $\begin{array}{l}\text { Aandacht voor } \\
\text { samenwerking }\end{array}$ & $\begin{array}{lr}\text { student-tutoren } & 96 \\
\text { staf-tutoren } & 106\end{array}$ & $\begin{array}{l}2,9 \\
2,9\end{array}$ & $\begin{array}{l}0,7 \\
0,7\end{array}$ & 0,47 & 0,49 \\
\hline
\end{tabular}


Tabel 6.5

Gemiddelden, standaardafwijkingen en significantieniveaus in het blok "Onrechtmatig gedrag"

\begin{tabular}{|c|c|c|c|c|c|c|}
\hline Schaal & Conditie & $\mathrm{N}$ & Gemiddelde & $\mathrm{SD}$ & $\begin{array}{l}\text { F geob- } \\
\text { serveerd }\end{array}$ & $\begin{array}{l}\text { p geob- } \\
\text { observeerd }\end{array}$ \\
\hline $\begin{array}{l}\text { Gebruik van } \\
\text { expertise }\end{array}$ & $\begin{array}{l}\text { student-tutoren } \\
\text { staf-tutoren }\end{array}$ & $\begin{array}{l}87 \\
63\end{array}$ & $\begin{array}{l}3,0 \\
3,2\end{array}$ & $\begin{array}{l}0,4 \\
0,5\end{array}$ & 9,85 & 0,002 \\
\hline $\begin{array}{l}\text { Cognitieve } \\
\text { congruentie }\end{array}$ & $\begin{array}{l}\text { student-tutoren } \\
\text { staf-tutoren }\end{array}$ & $\begin{array}{l}87 \\
63\end{array}$ & $\begin{array}{l}3,6 \\
3,3\end{array}$ & $\begin{array}{l}0,5 \\
0,6\end{array}$ & 16,03 & 0,001 \\
\hline Toetsoriëntatie & $\begin{array}{l}\text { student-tutoren } \\
\text { staf-tutoren }\end{array}$ & $\begin{array}{l}87 \\
63\end{array}$ & $\begin{array}{l}2,4 \\
2,1\end{array}$ & $\begin{array}{l}0,6 \\
0,6\end{array}$ & 10,41 & 0,002 \\
\hline Autoriteit & $\begin{array}{l}\text { student-tutoren } \\
\text { staf-tutoren }\end{array}$ & $\begin{array}{l}87 \\
63\end{array}$ & $\begin{array}{l}1,5 \\
2,0\end{array}$ & $\begin{array}{l}0,4 \\
0,7\end{array}$ & 30,62 & 0,001 \\
\hline Rolcongruentie & $\begin{array}{l}\text { student-tutoren } \\
\text { staf-tutoren }\end{array}$ & $\begin{array}{l}87 \\
63\end{array}$ & $\begin{array}{l}3,1 \\
2,5\end{array}$ & $\begin{array}{l}0,6 \\
0,6\end{array}$ & 40,67 & 0,001 \\
\hline $\begin{array}{l}\text { Aandacht voor } \\
\text { samenwerking }\end{array}$ & $\begin{array}{l}\text { student-tutoren } \\
\text { staf-tutoren }\end{array}$ & $\begin{array}{l}87 \\
63\end{array}$ & $\begin{array}{l}2,8 \\
2,6\end{array}$ & $\begin{array}{l}0,7 \\
0,8\end{array}$ & 2,91 & 0,09 \\
\hline
\end{tabular}

\section{Discussie}

\section{Verschillen in gebruik van expertise}

Verondersteld werd dat de student-tutoren minder gebruik zouden maken van hun vakinhoudelijke deskundigheid dan de staf-tutoren. Deze veronderstelling was gebaseerd op twee gronden. Ten eerste werd aangenomen dat de studenttutoren over minder kennis beschikken dan staf-tutoren. Ten tweede dat de student-tutoren zich meer faciliterend en minder directief zouden opstellen ten opzichte van de zelfwerkzaamheid van de studenten dan de staf-tutoren. De Tabellen 6.4 en 6.5 geven de gemiddelden en standaarddeviaties van de student-tutoren en de staf-tutoren op deze schaal weer. In het blok "Rechtshandeling" verschillen de student-tutoren niet van de staf-tutoren in het gebruik van hun expertise tijdens de discussie in de onderwijsgroep. In het blok "Onrechtmatig gedrag" is er echter een verschil in de voorspelde richting. Nadere analyse van deze dimensie op itemniveau laat interessante verschillen zien tussen beide blokperiodes. In het blok "Rechtshandeling" worden er weinig verschillen tussen de items gevonden. De meeste items laten 
non-significante verschillen zien. Slechts op 2 items kan een significant verschil tussen beide condities gevonden worden. De student-tutoren "lieten frequenter weten dat ze van een bepaald onderwerp slecht op de hoogte waren" ( $p<0.001)$. De staf-tuturen benadrukken sterker dan de studenttutoren "het toepassen van reeds opgedane kennis op voorbeelden uit de praktijk" (p<0,01).

In het blok "Onrechtmatig gedrag" zijn er een viertal items waarop de staf-tutoren sterk significant verschillen van de student-tutoren. Staf-tutoren "maken meer gebruik van hun vakinhoudelijke deskundigheid bij het begeleiden van de groep" ( $p<0,001$ ), ze "verbeteren de studenten meer met een beroep op hun vakinhoudelijke deskundigheid" ( $p<0,001$ ). De student-tutoren laten daarentegen vaker "weten dat ze van een bepaald onderwerp slecht op de hoogte zijn" ( $p<0,001)$ en stellen zich vaker "vakinhoudelijk terughoudend op" ( $p<0,02)$. Er vindt dus binnen deze schaal een gedeeltelijk compensatie-effect plaats. Op de andere items binnen deze schaal kunnen geen verschillen geconstateerd worden.

Tijdens de interviews benadrukken de studenten vooral de meer actieve opstelling van de student-tutoren. Maar de studenten laten ook vaker blijken dat het benutten van de vakinhoudelijke deskundigheid door de stafledentutor veel bijdraagt aan hun leren. Enkele studenten daarover:

"Fantastisch. De tutor zit er dicht bovenop. Dat men er is en zijn werk gedaan heeft. Bij het vorige blok vond ik de tutor niet zo goed functioneren. Veelal wist hij zelf een aantal zaken van staatsrecht niet. Dat moest dan eerst nagevritagd worden. De huidige tutor neemt wat meer de leiding op zich. ... Je gaat gewoon veel uitgebreider te werk. Je krijgt meer ingangen. En hij vult ook niet alleen wat in het blokboek staat qua literatuur aan, maar hij zegt ook 'lees dat eens, doe dat eens', 'kijk eens in het studielandschap naar dat boek. Probeer daar eens uit te lezen'. Persoonlijk vind ik dat heel prettig." (student 3.05)

Soms kan de wijze waarop een tutor van zijn vakinhoudelijke deskundigheid gebruik maakt ook uit de hand lopen. Twee illustraties:

"Het eerste gedeelte van het blok, daar wist de tutor weinig vanaf. Dat was zijn vakgebied niet en hij hield zich heel erg op de achtergrond. Toen vielen stiltes van wel vijf minuten, waarin helemaal niets werd gezegd. Vreselijk was dat. Het tweede gedeelte van het blok was wel zijn vakgebied. Toen praatte hij ontzettend veel. Het was echt te merken wat nou zijn vakgebied was. En dat vind ik nou zo jammer. Je moet toch een groep kunnen begeleiden, ook als het je vakgebied niet is. Het bleek erg duidelijk dat hij gefixeerd was op wat hij wist." (student 4.05)

"We hadden ook nog een beetje de handicap een zeer intelligente tutor te hebben, die er ook nog eens zijn eigen mening op na hield. Wat zijn goed recht is, maar, hij bracht die ook duidelijk naar voren. Dat kwam nog eens boven op de verwarring die toch al in de groep heerste. Je had dus al de verschillende meningen die in de handboeken stonden, en dan zei hij ook nog eens: 'Eigenlijk is dat onzin wat daar staat, want ...' Ik denk dat hij dan ook nog wel vaak gelijk had, maar je raakt dan natuurlijk helemaal in verwarring. Hij kon zich niet goed voorstellen wat de denkwereld van de studenten was en zich daarin inleven. Dat de studenten nog atin het exploreren waren hoe de zaken in elkaar zaten. ... Het daagde mij aan de ene kant wel uit om erbij te 
blijven, om kritisch na te denken. Aan de andere kant was het heel vaak onduidelijk door de warrige manier van behandelen. Als je dan uit die groep kwam dan dacht je: 'Ja, mijn god, wat heb ik, om nou in ouderwetse termen te blijven, wat heb ik nou geleerd.' Maar ik heb wel zitten genieten van zijn manier van werken." (student 4.07)

\section{Verschillen in cognitieve congruentie}

Aangenomen werd dat de student-tutoren zich beter zouden kunnen verplaatsen in de denkwereld van hun medestudenten omdat hun kennisstructuur nog in sterke mate lijkt op het kennisbestand van door hen begeleide studenten. De Tabellen 6.4 en 6.5 geven de gemiddelden en standaarddeviaties van de student-tutoren en de staf-tutoren op de schaal 'cognitieve congruentie' weer. In beide onderwijsblokken is er sprake van een sterk verschil in de wijze waarop student-tutoren en staf-tutoren zich inleven in de denkwereld van de studenten. Student-tutoren lukt dit blijkbaar beter. Nadere analyse van de schaalitems leidt tot de constatering dat met name de items "De tutor leek op dezelfde wijze over de stof te denken als wij" ( $p<0,001)$, "De tutor gebruikte dezelfde terminologie als wij" $(p<0,002)$ en "De tutor stelde begrijpelijke vragen" ( $p<0,001)$ sterk significante verschillen laten zien ten gunste van de student-tutoren. Slechts het item "De tutor slaagde erin iets op een eenvoudige wijze uit te leggen" toont geen significante verschillen $(\mathrm{p}<0,37)$.

Ook tijdens de interviews die voorafgaande aan en tijdens dit blok werden afgenomen, merkten veel geïnterviewden veelvuldig op dat ze de ervaring hadden dat de student-tutoren zich een betere voorstelling kunnen maken van hun problemen met de leerstofverwerking. Dit verschil in inlevingsvermogen wordt door enkele studenten als volgt onder woorden gebracht:

"... Van een student-tutor merk je dat die heel dicht bij je staat, omdat hij nog zelf in het onderwijsgroepsgebeuren zit. En doorgaans heel goed in de gaten heeft waar het probleem ligt. ... Ze staan ook dichterbij de moeilijkheden die studenten ervaren. ... Ik merk b.v. als ik een hoofddocent heb, dat die mensen veel verder zijn en al veel verder denken. Dat ze bepaalde dingen verwachten, ook bepaalde dingen in de manier van denken van de studenten gewoon niet begrijpen. Omdat het volgens hun, denk ik dan, te simpel gaat of wat dan ook. ... Ik denk dat dat komt omdat die mensen een enorme voorsprong hebben in hun manier van denken. En ik merk dat heel veel van dat soor mensen zich niet kunnen verplaatsen in de denkwijze van een eerstejaars student. Mensen die in feite aan de basis staan van hun studie. En dat zie je niet zozeer bij student-assistenten. Die hebben veel beter in de gaten, uit eigen ervaring, waar de problemen liggen, waar het knelt. En ook wat verwacht wordt straks. Die hebben beter in de gaten wat de grote lijn, de basis is." (student 0.11 )

"Tja, ik heb het liefst een student als tutor. Ook omdat die veel dichter bij de student zelf staan. Omdat die door hebben wat de moeilijkheden zijn, omdat ze daar zelf ook ooit eens tegenaan zijn gelopen. ... Ze zijn meer betrokken bij de stof zelf. Staan er minder boven. Ik denk dat ze heel duidelijk zien dat je als student met bepaalde onderdelen moeilijkheden kunt hebben. Of omdat de grote lijn je ontbreekt, of omdat je juist de details niet snapt." (student 0.(5). 
"De (student-)tutor staat niet zo ver van je af en ze laat je merken dat ze ook decelfde problemen heeft gehad en dat ze heel goed begrijpt waar wij mee zitten als we iets zeiden. Want ik vind dat als je een inhoudsdeskundige hebt, die staat toch iets verder van je af, meer de verhouding leraar - leerling. En die strooit heel wat met zijn inhoud, maar die kan zich gevoelsmatig weinig echt inleven in wat onze problemen zijn. Zo'n inhoudsdeskundige gaat meteen een hoop leerstof op je afschieten, maar die merkt niet echt wat nou de echte problemen zijn. Dat vind ik nou het voordeel van student-tutoren." (student 4.05)

Doordat student-tutoren tamelijk recent soortgelijke problemen met de verwerking van de leerstof hebben meegemaakt, zullen ze waarschijnlijk ook eerder dan staf-tutoren onderkennen wanneer studenten de leerstof niet begrepen hebben. Een student hierover:

"Ze (een student-tutor, JM) begreep precies waar wij mee worstelden op zo'n moment. Terwijl andere tutoren wel eens na een tijdje zeiden: 'Oh, is dat wat jullie probleem is, eh, dat zit zus en zo, had zij echt vaak dat zij meteen in één woord kon aangeven waar wij mee zaten." (student $0.04)$

Meerdere geïnterviewden merkten bovendien op dat de student-tutoren op een andere wijze de stof uitlegden. Een voorbeeld:

\begin{abstract}
"Student-assistenten leggen wat concreter uit dan stafleden. Meer gericht op de stof. Ze wijzen meer: 'Kijk daar eens naar', 'kijk eens naar dat voorbeeldje.' ... Meer concrete dingetjes, zodat het voor jezelf wat meer gaat leven. Als alles een beetje algemeen wordt gehouden, dan kun je je er soms moeilijk een voorstelling van maken. Stafleden geven je over het grotere geheel wat meer inzicht. Je hangt er boven (de leerstof, JM) en je kijkt er meer op neer. Je kunt daardoor de verbanden duidelijker zien." (student 0.01 )
\end{abstract}

\title{
Verschillen in de mate van toetsgerichtheid
}

Aangenomen werd dat de student-tutoren zich sterker zouden oriënteren op de bloktoets dan de staf-tutoren. De Tabellen 6.4 en 6.5 geven de gemiddelden en standaarddeviaties van de student-tutoren en de staf-tutoren op de schaal 'toetsoriëntatie' weer. Er is sprake van een sterk verschil in de wijze waarop student-tutoren en staf-tutoren zich richten op de bloktoets. Studenttutoren doen dit blijkbaar veel sterker. Nadere analyse van deze schaal laat zien dat student-tutoren vaker de groepsleden "waarschuwen voor de zwaarte van het blok" $(p<0,002)$, en vaker "verwijzen naar de zak- en slaagcijfers in voorgaande studiejaren" $(p<0,07)$.

Ook uit de interviews komt naar voren dat de student-tutoren meer op de bloktoets georiënteerd zijn dan de staf-tutoren. Enkele voorbeelden:

\footnotetext{
"Student-assistenten ... geven ook aan wat je moet bestuderen voor de bloktoets. 'Dat is echt een relevant stuk, dat moet je weten, daar zou je wel eens een vraag over kunnen krijgen' of 'dat heb je in de loop der jaren veel nodig.' Het ligt bij student-tutoren nog allemaal heel vers in het geheugen, en vooral omdat ze zelf die ervaring nog hebben, kunnen ze het ook aan ons overbrengen. Ze kunnen, omdat het nog zo vers in hun geheugen ligt, ook beter voorbeelden geven. Ze
} 
weten wat belangrijk is voor een toets, daardoor zijn de voorbeelden wel duidelijk." (student $0.01)$

"De student-assistent heeft wel op dingen zitten wijzen die we moesten kennen. Ze heeft heel belangrijke tips gegeven, zoals 'je moet gewoon de verschillende meningen en arresten van die schrijvers proberen te vertellen op de bloktoets. Dat geeft je veel meer punten.' Nou daar had ze ook gelijk in. Ze gaf je hints hoe je nou een bloktoets moest maken. Dat was heel fijn. Ze zei dan: 'En daar kun je wat meer punten mee behalen als je het zo vertelt. En noem ook die termen, dat is veel beter dan wanneer je het zo zegt. Ze willen die termen van ons horen, niet alleen die uitleg.' Dat deed ze veel meer dan de stafleden die ik als tutor heb gehad. Ik denk dat ze volop in die bloktoetsen zit en daarom voelt ze natuurlijk ook mee. Want zij studeert ook tegelijkertijd voor haar bloktoets." (student 0.03)

Maar de bloktoets wordt ook wel eens als 'stok achter de deur" gebruikt.

"Sommige tutoren, vooral die ongeïntesseerde (staf-tutor, JM), zei welhaast elke bijeenkornst: 'Dat zou ik maar goed bestuderen, dat moet je toch wel weten voor de bloktoets.' Hij was erg bloktoetsgericht. Ik vond dat niet de juiste manier." (student 3.09)

\section{Verschillen in autoriteit}

Verondersteld werd dat staf-tutoren meer en vaker gebruik zouden maken van hun autoriteit in een onderwijsgroep. De Tabellen 6.4 en 6.5 geven de gemiddelden en standaarddeviaties van de student-tutoren en de staf-tutoren op deze schaal weer. Ook hier stemmen de resultaten overeen met de hypothese. De staf-tutoren stellen zich vaker formeler en meer schoolmeesterachtig op dan de student-tutoren. In het blok "Onrechtmatig gedrag" zijn de verschillen sterker dan het blok "Rechtshandeling". Nadere analyse van deze schaal laat zien dat de staf-tutoren vaker "optreden als een "ouderwetse schoolmeester" $(\mathrm{p}<0,001)$, dat ze vaker "kleinerende opmerkingen maken wanneer de studenten bij de bespreking van een onderwerp de plank missloegen" $(p<0,08)$ en dat ze vaker laten merken 'dat hun mening de enig juiste was" ( $p<0,09)$.

Tijdens de interviews merkten de studenten ook vaker op dat de staftutoren zich wat vaker afstandelijker opstelden. Twee respondenten zeggen over hun waarneming van staf-tutoren:

"Ja, hij is ook wat afstandelijker zeg maar. Maar dat komt misschien omdat deze tutor al wat ouder is in vergelijking met mijn vorige tutor. En die was nou bijna net zo oud als wij waren." (student 3.15)

"Je bent samen nog student. Heel vaak kijk je toch nog een beetje tegen zo'n stafmedewerker op. Dat is natuurlijk ook fout, maar toch heb je daar meer een drempel te overwinnen. Terwijl je bij zo'n student-assistent, toch veel meer naar ze toegaat. Veel opener met ze kunt spreken." (student $0.10)$

"De tutor stelde zich al meteen erg afzijdig op. 'Ik zeg niks, jullie moeten het allemaal vertellen en als jullie erg de mist ingaan, dan vertel ik het.' Hij nam direct zo'n houding aan. En dan krijg je zo'n gevoel van: 'Ik houd mij ook maar wat terug'." (student 0.03 ) 


\section{Verschillen in rolcongruentie}

Aangenomen werd dat de student-tutoren gemakkelijker een persoonlijke relatie met de leden van de onderwijsgroep zouden aangaan dan de staf-tutoren. De Tabellen 6.4 en 6.5 geven de gemiddelden en standaarddeviaties van de student-tutoren en de staf-tutoren voor deze schaal weer. In beide onderwijsblokken zijn er sterk significante verschillen tussen student- en staf-tutoren. Student-tutoren kunnen zich beter inleven in de leefwereld van de studenten dan staf-tutoren. Kenmerkend voor deze schaal is dat alle items, op een na, sterke significante verschillen laten zien. Het item "De tutor toonde betrokkenheid bij onze studie" is niet-significant $(\mathrm{p}<0,72)$ Beide groepen tutoren vertonen dit gedrag in even sterke mate. De studenten die begeleid werden door een student-tutor zijn van mening dat hun tutor "meer belangstelling had voor de persoonlijke leefwereld van de groepsleden" $(\mathrm{p}<0,006)$, vaker "liet blijken dat hij of zij informeel contact met de studenten plezierig vond" ( $\mathrm{p}<$ $0,002)$, meer "vertelde over zijn persoonlijke studie-ervaringen" $(\mathrm{p}<0,001)$, meer "waardering toonde voor het werk van de studenten" $(p<0,001)$ en meer "begrip had voor de problemen die een eerstejaars met zijn studie heeft" $(p<0,003)$ dan de studenten die begeleid werden door staf-tutoren.

Tijdens de interviews kwamen de studenten vaak op dit verschil in interesse voor de student terug. Enkele geïnterviewden zeiden daarover:

"Student-assistenten weten waar ze mee bezig zijn, hoe de groep eigenlijk behoort te werken. Die zijn hier opguleid. Die zijn er mee opgegroeid. Die weten wat een student eigenlijk nodig heeft van een tutor. En ik vind dat van stafleden meestal erg tegenvallen. ... Die ene die ik gehad heb. Tja, het interesseerde hem eigenlijk helemaal niks. Of je er nou was of niet. Maakte hem helemaal niets uit. Terwijl een student-assistent wel zei: 'Kom op, jullie moeten er zijn. Dat is heel belangrijk. Enne, we gaan er samen tegenaan. En als je ergens mee zit dan kom je maar. Als je zo'n band hebt, is dat veel leuker. Dan heb je ook veel meer zin om er hard tegen aan te gaan." (student 0.10 )

"Van de student-tutor merk je dat die heel erg dicht bij je staat, omdat hij zelf nog in het onderwijsgroepsgebeuren zit. En doorgaans heel goed in de gaten heeft waar het probleem ligt of hoe mensen bepaalde dingen ervaren die in de onderwijsgroep gebeuren. En hoe ze dat moeten sturen, welke kant ze op moeten." (student 0.11 )

"Ik vond het knap hoe zo'n student-tutor dat deed. Ik vond dat wel motiverend. Is zelf aan het derde studiejaar bezig en geeft ons les. Ze was erg gemotiveerd. En dat maakte mij benieuwd waar haar interesse vandaan komt. ... Ze zei ook af-en-toe dingen als' ja, daar had ik in het eerste jaar ook moeilijkheden mee' of 'daar moet je goed uitkijken want dat krijg je over een jaar weer en dat wordt dan meer uitgediept.' Zij maakte haar eigen studieweg duidelijk, haar eigen problemen met de leerstof, haar eigen oplossingen en ervaringen." (student 0.06)

\section{Verschillen in aandacht voor samenwerking}

Aangenomen werd dat er geen verschillen zouden optreden tussen studenttutoren en staf-tutoren in hun belangstelling voor de wijze waarop de studen- 
ten in de onderwijsgroep zouden samenwerken. De Tabellen 6.4 en 6.5 geven de gemiddelden en standaarddeviaties van de student-tutoren en de staf-tuturen op deze schaal weer. De student-tutoren verschillen niet van de staftutoren in hun belangstelling voor de wijze van samenwerking tijdens de discussie in de onderwijsgroep. In het blok "Onrechtmatig gedrag" is wel een klein significant verschil te constateren. Student-tutoren besteden dan iets meer aandacht aan het functioneren van de groep dan staf-tutoren.

\section{Algemene discussie}

In dit hoofdstuk werd nagegaan of er verschillen optreden in de wijze waarop staf- en student-tutoren de onderwijsgroepen begeleiden. Verondersteld werd dat de student-tutoren proberen hun geringere vakinhoudelijke deskundigheid te compenseren door de leden van hun onderwijsgroep op een andere wijze te begeleiden dan de staf-tutoren. Op grond van theoretische overwegingen, eerder onderzoek naar mogelijke verschillen tussen student-en staf-tutoren, observaties en interviews werd een observatielijst 'tutorgedrag' ontwikkeld. Deze lijst bestond uit 46 items betreffende het gedrag van de tutor. Tijdens de laatste week van het blok "Rechtshandeling" en "Onrechtmatig gedrag" werd aan alle studenten die het onderwijs in genoemde blokken volgden, gevraagd deze lijst in te vullen. De betrouwbaarheid afgemeten aan de generaliseerbaarheid is goed en afgemeten aan de interne consistentie redelijk, terwijl er geen items in de lijst voorkomen die als synoniem moeten worden beschouwd. Ten aanzien van de constructvaliditeit zijn de gegevens uit de confirmatorische factoranalyse bemoedigend, hoewel de kanttekening gemaakt moet worden dat van een werkelijke "fit" nog niet gesproken kan worden.

Een vergelijking van de wijze waarop staf-tutoren en student-tutoren in hun onderwijsgroepen de tutorrol uitoefenen, laat zien dat beide groepen op een aantal kenmerken van optreden in de onderwijsgroep verschillen. Uit de resultaten lijkt geconcludeerd te kunnen worden dat de student-tutoren in beide onderwijsblokken op de kenmerken 'cognitieve congruentie', 'toetsoriëntatie' en 'rolcongruentie' sterk significant verschillen van de staf-tutoren. De student-tutoren lijken beter in staat zich in te leven in de denkwereld (cognitieve congruentie) en de leefwereld (rolcongruentie) van de studenten. Tevens zijn ze sterker op de bloktoets gericht dan de staf-tutoren (toetsoriëntatie). Eveneens worden significante verschillen gevonden op het kenmerk "autoriteit" tussen student- en staf-tutoren. De staf-tutoren stellen zich in de ogen van de studenten met meer autoriteit op tijdens de onderwijsgroepsbijeenkomsten. Ze gaan op een formelere wijze om met de leden van hun onderwijsgroep en controleren sterker wat er in de leersituatie gebeurt.

Wisselende significante verschillen werden gevonden in de wijze waarop student- en staf-tutoren hun 'expertise gebruiken' bij het begeleiden van het leerproces. In het blok "Rechtshandeling" worden geen verschillen gevonden, 
in het daaropvolgende blok wordt wel een significant verschil geconstateerd. Stafleden gebruiken hun expertise in dat blok veelvuldiger en sterker. Met betrekking tot het kenmerk 'aandacht voor samenwerken' werd in het blok "Rechtshandeling" geen verschil in optreden geconstateerd, in het blok "Onrechtmatig gedrag' lijken student-tutoren meer aandacht te hebben voor de wijze waarop onderwijsgroep en gespreksleider functioneerden dan de staf-tutoren.

De gegevens verkregen uit deze studie met betrekking tot 'cognitieve congruentie' lijken de veronderstelling van Cornwall (1980) en Ten Cate, Tromp en Cornwall (1984) te bevestigen. Cornwall en Ten Cate et al. veronderstelden dat de bevindingen dat leerprestaties van studenten begeleid door studentdocenten niet verschilden van studenten begeleid door staf-docenten beïnvloed zou kunnen zijn door het feit dat de student-docenten zich beter zouden kunnen inleven in de denkwereld van de studenten die zij begeleiden. Zij veronderstelden dat in dergelijke student-geleide onderwijssituaties sprake is van een grotere cognitieve congruentie. Deze grotere overeenstemming in de kennisstructuur zou ertoe kunnen bijdragen dat studenten begeleid door student-docenten meer leren van hun begeleider.

Hoewel in deze studie dus ondersteuning is gevonden voor de veronderstelling dat student-tutoren op een andere wijze optreden in het begeleiden van onderwijsgroepen dan staf-tutoren is enige voorzichtigheid geboden bij de interpretatie van deze gegevens. Zo vond het onderzoek post hoc plaats. $\mathrm{Na}$ afloop van het blok werd aan de studenten gevraagd een overzicht te geven van het optreden van hun tutor gedurende de onderwijsperiode. Onderzoek tijdens de onderwijsperiode, bijvoorbeeld door middel van getrainde observatoren, vond niet plaats. De mogelijkheid bestaat dat de studenten achteraf niet zozeer een beschrijving gegeven hebben van wat ze feitelijk hebben waargenomen maar een reconstructie op basis van stereotypen over wat van student-tutoren versus staf-tutoren verwacht kan worden. De variantie tussen de tutoren binnen de groepen duidt echter op waarnemingsverschillen. Een tweede bezwaar is de wijze waarop de meting heeft plaatsgevonden. Er werd gebruik gemaakt van een rating scale. Het gedrag van de tutoren werd niet gemeten door middel van gedragstelling. Het kan zijn dat de studenten staf-tutoren bijvoorbeeld "strenger" beoordeeld hebben dan hun "medestudenten". Ten derde zou men kunnen opmerken dat de correlatie tussen de verschillende kenmerken hoog is, hoewel de confirmatorische factoranalyse een redelijk fit oplevert. Er is dus voldoende reden om te veronderstellen dat het hier van elkaar te onderscheiden kenmerken betreft. Die kenmerken zijn echter niet noodzakelijkerwijs van elkaar onafhankelijk. Men kan zich bijvoorbeeld voorstellen dat de significante verschillen op de een variabele wellicht verschillen op andere variabelen veroorzaken. Onderzoek naar de samenhang van de verschillende variabelen is het thema van het volgende hoofdstuk. 


\section{Een causaal model van tutorfunctioneren}

\section{Inleiding}

In de vorige hoofdstukken werden resultaten van onderzoek naar verschillen tussen student- en staf-tutoren gepresenteerd. Dit onderzoek heeft slechts in bepaalde opzichten het inzicht in de rol van de tutor verdiept. We hebben betekenisvolle verschillen aangetoond in het gedrag van de verschillende categorieën tutoren. Student-tutoren zijn bijvoorbeeld beter in staat zich in te leven in de denk- en leefwereld van de studenten. Staf-tutoren proberen meer controle uit te oefenen op de wijze van werken in de onderwijsgroep. Daarnaast blijken staf-tutoren over meer kennis te beschikken dan student-tutoren.

Die verschillen lijken echter, blijkens de resultaten gepresenteerd in Hoofdstuk 4 en Hoofdstuk 5, niet echt tot uitdrukking te komen in de inzet en prestatie van de studenten. Leidt die bevinding nu tot de conclusie dat het blijkbaar weinig uitmaakt hoe een tutor zich gedraagt? Op basis van de data, zoals gepresenteerd in de vorige hoofdstukken kan die conclusie niet getrokken worden. Het is op grond van de gegevens die tot dusver hier ter sprake kwamen bijvoorbeeld niet uit te sluiten dat een tutor die in hoge mate cognitief congruent is met zijn studenten, los van de vraag of het een docent of een student is, een positievere invloed heeft op het leren en daarmee op de prestatie van de studenten dan een tutor die slechts in minder mate cognitief congruent gedrag vertoont. Doel van het onderzoek dat in dit laatste hoofdstuk gepresenteerd wordt, is daarom na te gaan in hoeverre bepaalde gedragingen van tutoren, los van de vraag of dat gedrag door student-tutoren of staf-tutoren vertoond wordt, een positieve invloed hebben op het leren van studenten. Het vinden van dergelijke verbanden zou, naast theoretisch, ook 
praktisch van grout belang zijn, omdat tutoren dan op basis van deze kenmerken geschoold en geselecteerd zouden kunnen worden.

\section{Een model van tutorfunctioneren}

Het onderzoek naar verbanden tussen tutorgedrag, dat in dit hoofdstuk gepresenteerd wordt, is gebaseerd op een causaal model van probleemgestuurd onderwijs ontwikkeld door Gijselaers en Schmidt (1990) en Schmidt en Gijselaers (1990). In hun studie gingen Schmidt en Gijselaers de samenhang en invloed na van verschillende elementen van probleemgestuurd onderwijs. De volgende elementen van probleemgestuurd onderwijs werden door hen in hun onderzoek betrokken: de voorkennis van de student, de kwaliteit van het blokboek, het functioneren van de tutor, het functioneren van de onderwijsgroep, de hoeveelheid zelfstudietijd, de leerprestatie van de studenten behaald op een bloktoets en de belangstelling van de student voor het onderwerp dat in het blok aan de orde wordt gesteld. Voorkennis van de student, de kwaliteit van het blokboek en het functioneren van de tutor werden beschouwd als de 'input' variabelen, het functioneren van de onderwijsgroep en de tijd besteed aan zelfstudie werden opgevat als de 'proces'variabelen, de leerprestatie en de belangstelling voor het onderwerp werden gehanteerd als de 'output' variabelen. Figuur 7.1 geeft het theoretische model van Schmidt en Gijselaers (1990) weer. Schmidt en Gijselaers testten hun model met behulp van een serie opeenvolgende multipele regressie analyses, die de volgende padcoëfficiënten opleverden (zie Figuur 7.1).

De resultaten van het onderzoek van Gijselaers en Schmidt toonden vooral het belang van een goed geconstrueerd blokboek aan voor de kwaliteit van het leerproces in probleemgestuurd onderwijs. Het blokboek lijkt een grote, directe en indirecte, invloed op de proces- en outputvariabelen te hebben. Het functioneren van de tutor lijkt vooral invloed te hebben op het functioneren van de onderwijsgroep en de belangstelling van de studenten voor de aangereikte onderwerpen. Er wordt geen direct verband geconstateerd tussen het functioneren van de tutor en de leerprestatie van de student. De tutor heeft slechts een indirecte en betrekkelijk geringe invloed op de leerprestaties, namelijk via het functioneren van de onderwijsgroep en de studietijd. Dit hangt wellicht samen met het gegeven dat de vragenlijst waarmee het functioneren van de tutor gemeten werd geen items bevatte over de mogelijke invloed van de tutor op de leerprestatie van de studenten. Het meetinstrument waarmee Schmidt en Gijselaers het functioneren van de tutor in kaart brachten, bevatte slechts 11 items die zich vooral richtten op de vraag of de tutor voorgeschreven procedures volgde. 


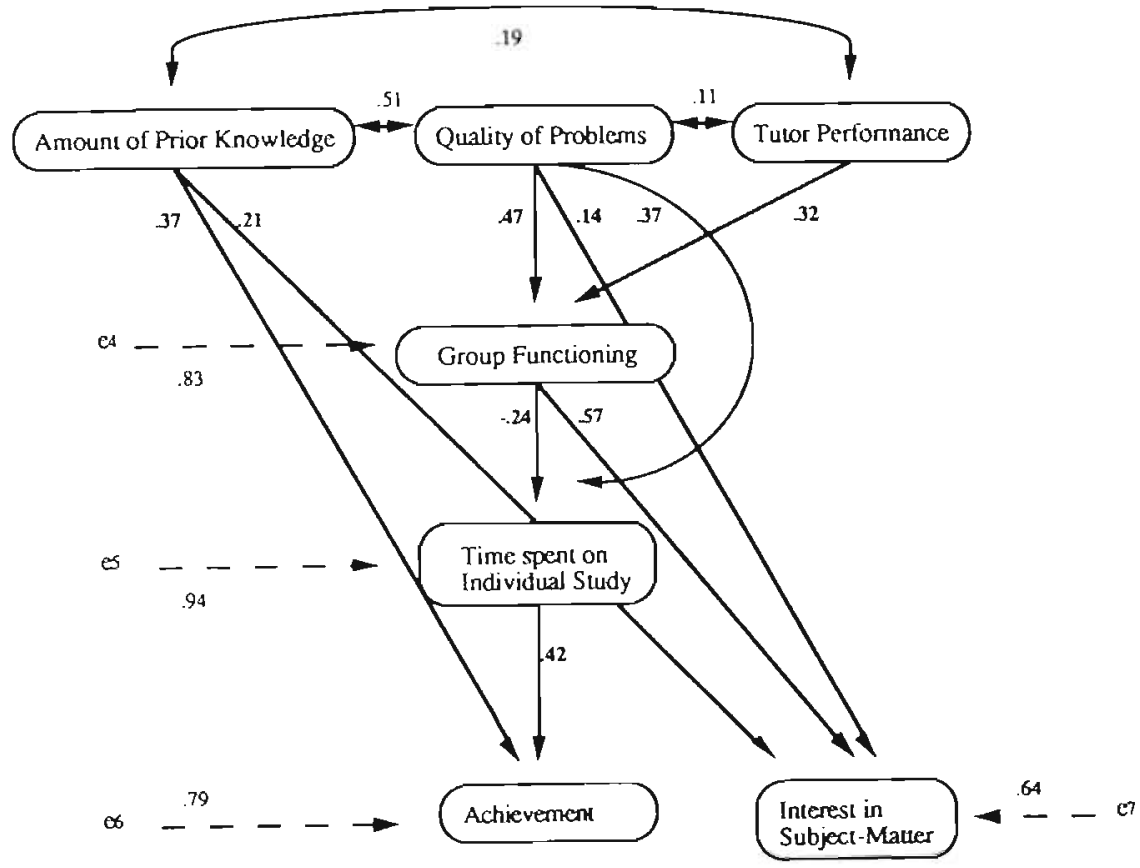

De veronderstelling die aan het hier beschreven onderzoek ten grondslag ligt, is dat nadere specificatie van de relevante gedragingen van de tutor wellicht bijdragen tot een meer genuanceerd beeld van de invloed van de tutor op het leren van de studenten. De verschillende aspecten van het functioneren van de tutor, die in Hoofdstuk 6 aan de orde zijn gesteld: gebruiken van expertise, cognitieve congruentie, toetsoriëntatie, autoriteit, rolcongruentie en bevorderen van samenwerking, lijken alle invloed te hebben op het functioneren en presteren van de studenten.

In onze overwegingen wordt een centrale rol toegekend aan het begrip cognitieve congruentie. De basis van probleemgestuurd onderwijs wordt immers gevormd door het gesprek, de discussie die de studenten met elkaar en met de tutor voeren over de leerstof. We hebben herhaaldelijk betoogd hoe belangrijk uitdieping en elaboratie is voor het begrijpen, onthouden en kunnen toepassen van leerstof. Een voorwaarde voor het succesvol verloop van een dergelijk gesprek is dat deelnemers elkaar begrijpen, met andere woorden zich uitdrukken in een taal die door de ander verstaan wordt. Cognitieve congruentie werd door ons gedefinieerd als het vermogen van de tutor om zich te verplaatsen in de denkwereld van de studenten. De tutor moet zich kunnen uitdrukken in termen die de student kent en begrijpt. Op grond van deze gedachtengang kan men niet anders redeneren dan dat cognitieve con- 
gruentie een centrale rol speelt in de effectiviteit van de interactie tussen studenten en tutor. Ook anderen benadrukken het belang van cognitieve congruentie in de context van het onderwijs in kleine groepen (Cornwall, 1980; Ten Cate, Tromp en Cornwall 1984). Men kan zich afvragen waarop het vermogen van de tutor om cognitief congruent te zijn met de studenten gebaseerd is. Is het ervaring? Is het een persoonlijkheidskenmerk, dat sommigen nu eenmaal wel, anderen niet bezitten? Betreft het hier een karaktertrek waarop training en vorming relatief weinig invloed hebben? De auteur van dit proefschrift neemt hier aan dat het gaat om een situationeel bepaald kenmerk dat een functie is van tenminste drie factoren: het beschikken over relevante kennis, het vermogen om een persoonlijke verstandhouding aan te gaan met de studenten en het vermogen van de tutor om de studenten ruimte te geven om zelf invulling te geven aan hun leren. Dat een tutor voldoende kennis van het onderwerp dient te hebben waarop de discussie betrekking heeft, lijkt vanzelfsprekend. Zonder kennis weet de tutor niet waarover de studenten discussiëren. De tutor moet enigszins boven de stof staan en weten waarheen de discussie moet leiden. Interesse in de studenten en actief nastreven van een goede persoonlijke verstandhouding, gedragskenmerken die wij eerder hebben omschreven als rolcongruentie, lijken evenzeer voorwaarden te zijn voor cognitieve congruentie. Immers, als een tutor niet geinteresseerd is in zijn studenten, waarom zou hij dan pogingen ondernemen om aan te sluiten op hun denkwereld? Tenslotte moet de tutor ook de studenten de vrijheid bieden om hun gedachten te ontplooien. Wanneer de studenten zich belemmerd voelen door de controle die de tutor uitoefent op hun ideeën en beweringen zullen de studenten slechts meedoen aan de discussie als zij er zeker van zijn dat zij een foutloze bijdrage aan het gesprek kunnen leveren. Als deze redenering een adekwate specificatie vormt van wat Schmidt en Gijselaers (1990) globaal omschreven hebben als "het functioneren van de tutor" dan ontstaat het volgende model: zie Figuur 7.2. ${ }^{1}$

Wij zullen hier niet verder ingaan op overwegingen die ten grondslag liggen aan de causale verbanden tussen functioneren van de onderwijsgroep, hoeveelheid tijd besteed aan zelfstudie, leerprestatie en interesse in de leerstof. De lezer zij hiervoor verwezen naar het theoretische en empirische werk van Carroll (1963), Schmidt en Gijselaers (1990) en Haertel, Walberg, \& Weinstein (1983). Het is dit model dat aan een nadere analyse onderworpen werd.

${ }^{1}$ De andere factoren, toetsoriëntatie en aandacht voor samenwerking, werden buiten beschouwing gelaten omdat in een eerdere poging tot toetsing van meer complexe modellen bleek dat deze geen rol speelden. 
Tabel 7.1

Correlaties tussen de in het model gepostuleerde variabelen

$\begin{array}{llllllll}1 & 2 & 3 & 4 & 5 & 6 & 7 & 8\end{array}$

1. Gebruik van expertise

1,00

2. Cognitieve congruentie

$0,551,00$

3. Autoriteit

$0,03-0,44 \quad 1,00$

4. Rolcongruentie

$\begin{array}{llll}0,21 & 0,68 & -0,58 & 1,00\end{array}$

5. Functioneren onderwijsgroep

$\begin{array}{lllll}0,22 & 0,67 & -0,32 & 0,56 & 1,00\end{array}$

6. Tijd voor zelfstudie

$\begin{array}{llllll}-0,04 & -0,17 & 0,38 & -0,30 & -0,20 & 1,00\end{array}$

7. Interesse

$\begin{array}{lll}0,09 & 0,27 & -0,18\end{array}$

$\begin{array}{llll}0,19 & 0,35 & -0,22 & 1,00\end{array}$

8. Leerprestatie

$\begin{array}{llll}-0,22 & -0,01 & -0,09 & -0,10\end{array}$

$0,31 \quad 0,15 \quad 0,20 \quad 1,00$

De data uit Tabel 7.1 werden onderworpen aan een padanalyse volgens het model gepostuleerd in Figuur 7.2. De resultaten waren als volgt: Chikwadraat $=23,30$, d.f. $=19 ; \mathrm{p}=0,22$ n.s.; B.B. NFI $=0,79$; B.B. NNFI $=$ 0,92 en de $C F I=0,95$. Hieruit kan geconcludeerd worden dat het model goed past.

\section{Figuur 7.3}

Padanalyse van het model tutorfunctioneren

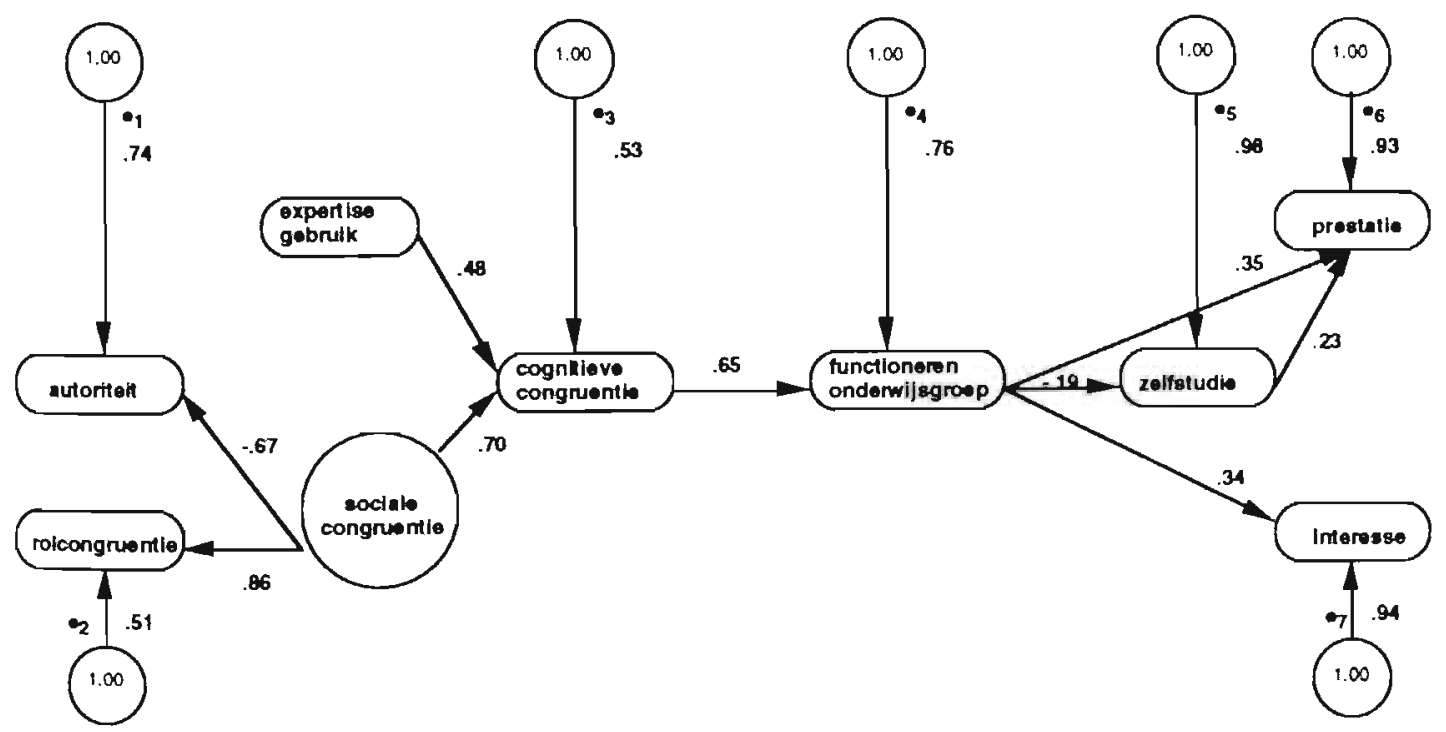


Het resultaat van de padanalyse wordt gepresenteerd in Figuur 7.3. Alle gewichten zijn gebaseerd op de maximum likelihood oplossing en bestaan uit gestandaardiseerde regressiecoëfficiënten. De directe effecten van gebruik van expertise en sociale congruentie van de tutor op cognitieve congruentie zijn positief en substantieel. Cognitieve congruentie heeft een sterke positieve invloed op het functioneren van de onderwijsgroep. Het functioneren van de onderwijsgroep heeft een directe invloed op de leerprestatie en motivatie van de studenten. Een zwakke negatieve directe invloed wordt gevonden tussen het functioneren van de onderwijsgroep en de tijd besteed aan zelfstudie. De paden tussen functioneren van de onderwijsgroep en prestatie en tijd besteed aan zelfstudie en leerprestatie zijn niet significant. (De pijlen gelabeld el tot en met e7 geeft de invloed aan van de residuen).

\section{Discussie}

Via het gesprek dat de leden van een onderwijsgroep met elkaar voeren over de leerstof worden belangrijke leerprocessen voor het begrijpen, onthouden en kunnen toepassen van informatie bevorderd. De studenten worden gestimuleerd hun voorkennis te activeren, leerstof te elaboreren en hun kennis toe te passen. Uit de literatuur over groepsonderwijs blijkt dat wanneer studenten meer met elkaar kunnen interacteren over de leerstof en wanneer deze interactie goed verloopt dit een positief effect heeft op de leerprestaties (Johnson, Maruyama, Johnson, Nelson \& Skon, 1981; Powell, 1974; Slavin, 1989; Ten Cate, 1986; Webb, 1982, 1989).

Om de kwaliteit van de discussie tussen de studenten te ondersteunen wordt aan de onderwijsgroep een tutor toegevoegd. In zijn rol van begeleider van de onderwijsgroep wordt van deze docent verwacht dat hij zorgvuldig luistert naar de discussie van de studenten om na te gaan waar hij het gesprek kan bijsturen, verdiepen of verhelderen. De bijdragen van de tutor aan de onderwijsgroep dienen gericht te zijn op het verbeteren van de kwaliteit van de interactie tussen de studenten onderling.

In deze studie is nagegaan in hoeverre bepaalde gedragingen van de tutor een positieve bijdrage leveren aan de kwaliteit van de interactie in een onderwijsgroep en op het leren van de studenten. Daarbij werd uitgegaan van drie aspecten van het functioneren van de tutor. Belangrijk voor het adekwaat functioneren van een tutor in een onderwijsgroep lijkt op de eerste plaats te zijn dat de tutor over een redelijke mate van vakinhoudelijke deskundigheid beschikt. De tutor moet voldoende kennis van het onderwerp hebben om te begrijpen waarover de studenten discussiëren en waarheen de discussie moet leiden. Zonder deze kennis is de tutor bijvoorbeeld niet in staat om kritische vragen te stellen over de leerstof waardoor de studenten na kunnen gaan of ze de leerstof begrijpen. Zonder vakinhoudelijke expertise is hij eveneens niet in staat enige uitleg te geven wanneer studenten het overzicht verliezen of 
kan hij geen voorbeelden aandragen waardoor de studenten gemakkelijker de leerstof onthouden of kunnen toepassen. Over de mate walarin de tutor moet beschikken over vakinhoudelijke deskundigheid kan moeilijk een algemene uitspraak gedaan worden. Afhankelijk van het onderwerp en het studieniveau van de studenten zal de mate van gewenste expertise van de tutor verschillen. In recente literatuur over het functioneren van tutoren in probleemgestuurd onderwijs zijn over de mate van vakinhoudelijke deskundigheid van de tutor twee opvattingen te vinden. Enerzijds is er de mening dat studenten begeleid moeten worden door vakinhoudelijk hoog gespecialiseerde tutoren. Door hun expertise zouden deze tutoren immers beter in staat zijn de discussie van de studenten te begeleiden. Recente onderzoeken van Davis, Naim, Paine, Anderson \& Oh (1992) en Eagle, Harasym \& Mandin, (1992) lijken deze opvatting te ondersteunen. De eerste studie toonde aan dat medische studenten begeleid door expert-tutoren hoger scoorden op een prestatiestoets dan studenten begeleid door non-expert tutoren; in de tweede studie formuleerden de studenten begeleid door de expert-tutoren meer leerdoelen en studeerden langer dan de studenten begeleid door de non-expert tutoren. In beide studies waren de non-expert tutoren medici, niet gespecialiseerd op het domein dat het blokthema behandelde. Anderzijds is er de opvatting dat de inhoudelijke deskundigheid van de tutor wel belangrijk is, maar dat de vaardigheden van de tutor in het begeleiden van het leer- en samenwerkingsproces van de onderwijsgroepsleden minstens zo belangrijk zijn om de kwaliteit van de discussie tussen de studenten te waarborgen (Barrows, 1988; Silver \& Wilkerson, 1991; Wilkerson, 1992). Barrows (1988) is zelfs van mening dat goede begeleidingskwaliteiten van een tutor geprefereerd moeten worden boven inhoudelijke deskundigheid. Uit een studie van Silver en Wilkerson (1991) bleek dat expert-tutoren meer directief gedrag vertoonden in de onderwijsgroep dan de non-expert-tutoren. De expert-tutoren waren vaker en langer aan het woord, gaven sneller een antwoord op de vragen van de studenten, suggereerden sneller de onderwerpen waarover gepraat moest worden en bevorderden sterker een interactiepatroon tussen studenten en tutor dan tussen studenten onderling. Hoewel over de mate van expertise van de tutor verschillend gedacht kan worden, duidelijk lijkt in ieder geval dat de tutor over een redelijke expertise met betrekking tot de aangeboden leerstof moet beschikken.

Naast de vakinhoudelijke expertise die de tutor meebrengt in een onderwijsgroep lijkt, ten tweede, ook de houding van de tutor ten opzichte van de leden van de onderwijsgroep invloed te hebben op de werkwijze en leerprestaties van de studenten. De tutor moet de studenten ruimte kunnen geven om met elkaar te discussiëren. Dit betekent dat de tutor zich (actief) luisterend moet opstellen naar de inbreng van de studenten en dat hij niet meteen corrigerend moet ingrijpen wanneer de studenten op de verkeerde weg zijn. De tutor moet enig geduld kunnen opbrengen en de studenten de gelegenheid geven om zichzelf te corrigeren. En àls de tutor ingrijpt, moet hij dat op 
zodanig wijze doen dat de studenten zich niet beoordeeld voelen op hun bijdragen. In de onderwijsgroep moet een veilige sfeer gecreëerd worden: de studenten moeten het gevoel hebben dat hun, veelal exploratieve, bijdragen atn het leerproces op de juiste wijze getaxeerd worden. Een tutor kan hier blijk van geven door betrokkenheid te tonen bij de leerervaringen die de studenten in en buiten de onderwijsgroep opdoen. Hij kan op een reële wijze zijn waardering tonen voor de pogingen van de leden van de groep om de leerstof te verwerken en te structureren. Cognitieve congruentie is een derde kenmerk van het gedrag van de tutor dat in deze studie verondersteld werd bij te dragen aan de leerprestaties van de studenten. Cognitieve congruentie werd omschreven als het vermogen van de tutor om zich te verplaatsen in de denkwereld van de studenten. Wil een tutor kunnen bijdragen aan de kwaliteit van de discussie van de studenten dan zal hij zich moeten kunnen uitdrukken in een taal die de studenten begrijpen. De bijdragen die de tutor levert om het leren van de studenten op gang te brengen en verder te ontwikkelen, moeten nauw aansluiten bij het kennisniveau dat de studenten in de onderwijsgroep creëren. Zijn uitleg of vragen moet niet over de hoofden van de studenten gesteld worden, noch mogen ze zo gemakkelijk zijn dat de studenten er niet door uitgedaagd of geholpen worden. Zijn bijdragen moeten telkens net op of boven het kennisniveau van de studenten liggen, zodat de studenten met behulp van zijn interventies zo zelfstandig mogelijk verder kunnen bouwen aan hun beheersing van de leerstof.

In dit hoofdstuk werd onderzocht of cognitieve congruentie inderdaad een centraal kenmerk is in het gedrag van de tutor om het leren van de studenten in de onderwijsgroep te bevorderen. Verondersteld werd dat cognitieve congruentie beïnvloed wordt door de wijze waarop de tutor zijn expertise gebruikt en het vermogen van de tutor om zich in te leven in de leefwereld van de studenten. Tutoren lijken pas cognitief congruent gedrag te kunnen vertonen als zij een zeker inzicht in en overzicht hebben over de leerstof én wanneer zij zich een beeld kunnen vormen van de leefwereld van de student. Uit de resultaten van deze studie blijkt dat cognitieve congruentie inderdaad een sterke invloed heeft op het functioneren van de onderwijsgroep $(r=0,65)$. Dit betekent dat $42 \%$ van de verschillen in het functioneren van onderwijsgroepen wordt verklaard door verschillen in cognitieve congruentie van tutoren. Ook de veronderstellingen ten aanzien van de expertise van de tutor en sociale congruentie worden zichtbaar in de redelijke tot hoge padcoëfficiënten, resp. $r=0,48$ en $r=0,70$. Er wordt geen directe verband gevonden tussen expertise van de tutor en leerprestatie. Dit betekent dat het kennisniveau van de tutor niet rechtstreeks van invloed is op de resultaten van de studenten op de toets. Evenmin worden rechtstreekse verbanden gevonden tussen sociale congruentie en leerprestatie. Dit betekent dat de wijze waarop de tutor omgaat met de studenten ook geen directe invloed heeft op de leerprestaties. Die invloed wordt als het ware "gekanaliseerd" via cognitieve congruentie. Even- 
1988: Levinson-Rose \& Menges, 1981). Feedback lijkt alleen effect te hebben als er een structuur gecreëerd wordt waarin verandering van gedrag ondersteund en beloond wordt (Weimer, 1990). De verkregen gegevens zouden daarom eveneens, in gecomprimeerde vorm, verstrekt moeten worden aan de facultaire organen die zich bezig houden met kwaliteitsbewaking van het onderwijs. Degenen die zich bezig houden met kwaliteitsbewaking, bijvoorbeeld de studierichtingscommissie en de vakgroepvoorzitters, moeten onderwijsprestaties op basis van deze summatieve programma-evaluatiegegevens, kunnen sanctioneren. Tutoren die hun rol regelmatig op een goede wijze vervullen, zouden hiervoor beloond moeten worden in het kader van het facultaire personeelsbeoordelingsbeleid. Tutoren die verschillende malen achtereen niet adekwaat functioneren moet de gelegenheid worden geboden tot bijscholing. Deze tutoren zouden de mogelijkheid moeten krijgen een aangepaste cursus "tutortraining" te volgen. Docenten die permanent onvoldoende functioneren in het uitvoeren van de tutorrol, zou geadviseerd moeten worden zich meer toe te leggen op de andere onderwijsrollen die binnen het probleemgestuurde onderwijs vervuld moeten worden.

\section{Begeleiding van tutoren}

Degenen die zich bezig houden met onderwijskundige professionalisering van stafleden moeten een programma van scholings- en begeleidingsactiviteiten aanbieden waarbinnen docenten de benodigde inzichten en vaardigheden met betrekking tot de tutorrol kunnen verwerven. We schetsen hier enkele mogelijkheden. In een introductiecursus voor nieuwe facultaire medewerkers moet een sterke nadruk gelegd worden op de faciliterende functie die zij als tutor moeten vervullen bij het leerproces van de studenten. Tutoren-in-spé moeten in deze cursus vertrouwd gemaakt worden met de wijze waarop studenten leren en welke rol zij kunnen vervullen om het leerproces van de student uit te lokken, te ondersteunen en te ontwikkelen. Het, in dit hoofdstuk beschreven model, moet hen duidelijk gemaakt worden zodat ze zich bewust worden van de specifieke bijdrage die cognitieve congruentie, sociale congruentie en vakinhoudelijke deskundigheid hebben bij het faciliteren van het leren van de studenten in de onderwijsgroep.

Daarnaast zullen in deze cursus de nieuwe medewerkers, bijvoorbeeld via microteaching, geoefend moeten worden in vaardigheden die zelfstandig leergedrag van de studenten ondersteunen. Aandacht zal besteed moeten worden aan de volgende vaardigheden: actief kunnen luisteren, zowel naar de inhoud als naar de intentie van de informatie die studenten naar voren brengen, vragen kunnen stellen die elaboraties op de leerstof door de studenten uitlokken en begrijpelijk kunnen uitleggen van informatie. Tijdens het verwerven of verder aanleren van deze vaardigheden is tevens van belang dat de cursisten leren op welke wijze ze deze vaardigheden aan de studenten kunnen overdragen. Tevens moeten tutoren getraind worden in het geven van inhoudelijke 
feedback op de bijdragen van de studenten en het creëren van probleemsituaties waarop de studenten hun kennis kunnen toetsen en toepassen. Studenten die bereid en geoefend zijn om adekwaat weer te geven welke interventies van tutoren stimulerend of belemmerend zijn voor hun verwerking van de leerstof zouden in deze oefensituaties een belangrijke rol kunnen vervullen. Zij kunnen het effect van de interventies van de cursisten op hun leer- en studiegedrag beschrijven.

Nadat tutoren op deze oriënterende wijze kennis gemaakt hebben met aspecten van faciliterend gedrag, zou het tweede deel van hun scholing plaats moeten vinden door een "training on the job". Tijdens hun eerste contacten met onderwijsgroepen zouden de "nieuwe" tutoren bijgestaan kunnen worden door een ervaren en bekwame tutor die al enige keren in het desbetreffende blok tutor geweest is. Deze tutor zou als observator een aantal onderwijsgroepsbijeenkomsten moeten bijwonen. $\mathrm{Na}$ afloop van iedere bijeenkomst krijgt de tutor van deze meer ervaren collega -- in onderlinge discussie -informatie aangereikt over de wijze waarop hij de onderwijsgroep begeleid heeft. Tijdens deze begeleiding zou het accent voomamelijk moeten liggen op de faciliterende functie die de tutor moet vervullen en de vaardigheden die daarbij behulpzaam kunnen zijn. Tevens zou in dit stadium van het verwerven van nieuwe onderwijskundige vaardigheden intensief gebruik moeten worden gemaakt van formatieve programma-evaluatie gegevens (Weimer, 1990). Met behulp van uitgebreide vragenlijsten, door de tutor zelf of in samenspraak met een onderwijskundige, studenten of andere tutoren ontwikkeld, zou de tutor na kunnen gaan op welke wijze hij zijn rol uitvoert en welke effecten zijn optreden tot gevolg heeft. Op basis van deze formatieve feedback kan de tutor dan beslissen wat hij wil veranderen in zijn begeleidingsstijl.

Voor de tutor die op grond van de studentbeoordelingen in aanmerking komt voor bijscholing zal een op maat gesneden cursus ontwikkeld moeten worden. In een dergelijke cursus zal bijvoorbeeld via video-observaties en observaties door meer ervaren tutoren of onderwijskundigen tijdens begeleidingsactiviteiten specifieke aandacht besteed moeten worden aan die onderdelen waarop de betreffende tutor slecht scoort.

In bovenstaande cursussen staan vooral algemene inzichten in en vaardigheden met het faciliteren van leergedrag centraal. De specifieke bijdrage van cognitief congruent gedrag van de tutor aan het leerproces van de studenten in de onderwijsgroep en hun leerprestaties, zal bijzondere aandacht moeten krijgen in een korte blokgebonden tutortraining. Voorafgaande aan een nieuwe blokperiode zullen de tutoren, die in een bepaalde blok actief zijn, tijdens een eendaagse cursus uitvoerig geinformeerd moeten worden over de eindtermen, inhoud en structuur van het blok. Tevens zullen de tutoren inzicht moeten krijgen in de samenhang van de verschillende onderwijsactiviteiten die in het blok plaatsvinden: onderwijsgroepen, hoorcolleges, practica. 
Tijdens deze bijeenkomst kunnen de tutoren dan tevens oefenen met enkele taken uit het blokboek. Centraal tijdens deze oefeningen moeten vragen staan als: "welke problemen zullen de studenten hebben met het begrijpen van deze taken en de daarbij behorende leerstof?"; "met welke vragen en probleemsituaties kunnen we het denken van de studenten stimuleren?"; "hoe kunnen we hen bepaalde verbanden tussen verschillende onderdelen in de leerinhoud laten ontdekken" en "hoe leg je bepaalde onderwerpen op een begrijpelijke wijze uit?" Deze en dergelijke vragen moeten ook voorop staan in het wekelijkse overleg van tutoren over de voortgang van de onderwijsgroepen tijdens de blokperiode, het zogenaamde tutoroverleg. Tijdens deze bijeenkomsten moet meer gedetailleerd nagegaan worden op welke kennisverwerkingsproblemen studenten stuiten tijdens de behandeling van de blokboektaken en de verschillende manieren waarop de tutoren bij de bespreking ervan een helpende hand kunnen bieden. In het tutorenoverleg zou bijvoorbeeld aandacht besteed kunnen worden aan de verschillende voorbeelden, geheugensteuntjes en ideeën over leerstoforganisatie die de tutoren in de groepsdiscussie naar voren brengen om elaboratie, toepassing en organisatie van kennis door de studenten te bevorderen. De verschillende hulpmiddelen, die afzonderlijke tutoren gebruiken om het leren van hun studenten te stimuleren, zouden tevens beschreven kunnen worden in het instructiemateriaal dat tutoren door de ontwikkelaars van een blokboek aangereikt krijgen, het zogenoemde tutorboek. Door tijdens de algemene tutortraining en meer blokspecifieke voorbereiding aandacht te besteden aan de verschillende manieren waarop tutoren concreet het leren van groepsleden kunnen bevorderen, krijgen tutoren in toenemende mate een rijker arsenaal van interventiemogelijkheden tot hun beschikking dat aangepast is aan het denkniveau en de problemen met het verwerken van de leerstof van de studenten in de onderwijsgroep. 

In 1982 begon de Rijksuniversiteit Limburg met de studierichting Nederlands Recht volgens de principes van probleemgestuurd onderwijs. Probleemgestuurd onderwijs kan omschreven worden als een benadering van het onderwijsleerproces waarbij studenten kennis verwerven door in een kleine groep te werken aan het begrijpen en eventueel oplossen van concrete problemen. Die problemen zijn door docenten geconstrueerd en rond een bepaald thema gegroepeerd. Ieder thema wordt gedurende een blokperiode van acht weken aan de orde gesteld.

$\mathrm{Na}$ een geleidelijke groei van de studentenaantallen in de eerste jaren van haar bestaan werd de Faculteit der Rechtsgeleerdheid in het studiejaar 1985 1986, als gevolg van universitair beleid, geconfronteerd met een aanzienlijk grotere instroom van eerstejaarsstudenten. De versnelde toename van studenten plaatste de faculteit voor de vraag of zij met het potentieel aan stafleden wel in staat zou blijven te voldoen aan één van de uitgangspunten van probleemgestuurd onderwijs: kleinschaligheid. Eén van de mogelijkheden om de probleemgestuurde aanpak van het onderwijs in stand te houden, was het inschakelen van ouderejaarsstudenten als begeleider van een onderwijsgroep. $\mathrm{Na}$ ampele discussie werd besloten met dit experiment te starten. Aanvankelijk bestond de indruk dat de ouderejaarsstudenten, die opteerden voor de functie van begeleider van een onderwijsgroep, in de praktijk goed voldeden. Onzekerheid hierover ging ontstaan, nadat enig onderzoek, in één onderwijsperiode, aantoonde dat studenten begeleid door ouderejaarsstudenten significant slechtere leerprestaties behaalden dan hun medestudenten die begeleid werden door stafleden. Op basis van deze indicatie werd besloten een meeromvattend onderzoek uit te voeren naar het functioneren van ouderejaarsstudenten en stafleden in de rol van tutor, begeleider van een onderwijsgroep. Doel van het onderzoek beschreven in dit proefschrift was dan ook te onder- 
zoeken of student-tutoren verschillen van staf-tutoren in de wijze waarop ze bijdragen aan het leerproces van studenten en of dat leidt tot verschillende leerresultaten.

Hoofdstuk 1 beschrijft de wijze waarop het onderwijs in de Maastrichtse juridische faculteit is ingericht. Na een korte schets van enkele onderwijskundige methoden waaruit probleemgestuurd onderwijs geëvolueerd is en de wijze waarop het curriculum in de Faculteit der Rechtsgeleerdheid is opgebouwd, wordt uitvoerig stil gestaan bij de wijze waarop studenten en tutoren betrokken zijn bij het verwerven en verwerken van de leerstof die de studenten wordt aangereikt.

Kenmerkend voor het probleemgestuurde onderwijsleerproces is de grote nadruk die gelegd wordt op de zelfwerkzaamheid van de studenten. Binnen de probleemgestuurde benadering van leren en instructie analyseren studenten als eerste stap de taken die hen door een groep docenten in het kader een bepaald thema worden aangeboden. Deze analyse vindt plaats in een onderwijsgroep bestaande uit een tiental studenten. Belangrijk tijdens dit analyseproces is dat de studenten zelf de probleemstelling(en) definiëren die zij uit de aangeboden informatie halen en dat zij zelf proberen, via een voorlopige inventarisatie van alle kennis waarover zij op dat moment beschikken, verklaringen aan te dragen voor de verschijnselen die in de taak beschreven zijn. Vervolgens formuleren de groepsleden, op basis van geconstateerde leemtes of tegenstrijdigheden in hun kennis, de leerdoelen die zij via studie willen bestuderen. De volgende stap bestaat uit een periode van zelfstudie waarbij de studenten door het raadplegen van literatuur, audiovisuele hulpmiddelen en docenten trachten een compleet beeld te verkrijgen van het externe kennisbestand dat een bijdrage kan leveren aan het begrijpen van de verklaringen voor het geschetste probleem. De laatste stap in het proces van probleemgestuurd onderwijs bestaat uit een nadere uitwisseling in de onderwijsgroep van de gevonden en bestudeerde informatie en een poging om alle verkregen informatie integraal toe te passen op het oorspronkelijke probleem.

De stappen van probleemanalyse, leerdoelformulering, individuele studie, synthese en toepassing van de verworven kennis, verlopen niet altijd vlekkeloos. Studenten hebben soms slechts vage ideeën welke verklaringen van toepassing kunnen zijn op een bepaald fenomeen, of ze formuleren hun leerdoelen te globaal, waardoor het proces van zelfstudie bemoeilijkt wordt. Ook in de rapportagefase kunnen er problemen optreden: de groepsleden onderkennen de samenhang binnen de leerstof onvoldoende, leggen verkeerde of onjuiste verbanden of kunnen de leerstof moeilijk concretiseren. De leden van een onderwijsgroep worden daarom bij hun pogingen greep te krijgen op het probleem en de daarop betrekking hebbende leerstof begeleid door een docent. Deze docent wordt tutor genoemd. Het is zijn taak om de studenten te 
ondersteunen in het proces van kennisverwerving en -uitwisseling en onderlinge samenwerking. De tutor kan de leden van een onderwijsgroep behulpzaam zijn met het leggen van verbanden tussen verschillende onderdelen van de leerinhoud, het toepassen van leerstof op door hemzelf aangedragen praktijksituaties of het formuleren van eenduidige, handzame leerdoelen. Daarnaast kan de tutor de leden van zijn onderwijsgroep ondersteunen in hun onderlinge samenwerking. Kenmerkend voor het handelen van de tutor is dat zijn of haar bijdragen meer gericht moeten zijn op het mogelijk maken van leergedrag van de studenten dan op het direct onderwijzen. De bijdragen van de tutor moeten de autonomie van de studenten bevorderen.

De vraag of ouderejaarsstudenten verschillen van stafleden in de wijze waarop ze bijdragen aan het leerproces van studenten en of dat leidt tot verschillende leerresultaten is hier niet voor het eerst gesteld. In Hoofdstuk 2 wordt een overzicht gegeven van het onderzoek naar, en mogelijke veronderstellingen voor, de effectiviteit van onderwijs waarbij de studenten geplaatst worden in de rol van docent. De resultaten van dat onderzoek zijn tegenstrijdig. In een aantal studies behalen de studenten begeleid door stafleden betere leerprestaties, in ander onderzoek worden geen verschillen geconstateerd. In weer ander onderzoek scoren studenten begeleid door studenten beter op de prestatiemeting. Deze heterogeniteit in de resultaten van dit onderzoek wordt geweten aan drie factoren: verschillen in de mate van structurering van de onderwijssituatie, verschillen in groepsgrootte en verschillen in prestatiemeting. In het ene onderzoek wordt bijvoorbeeld getoetst met behulp van multiple choice vragen, in een ander onderzoek wordt de leerprestatie gemeten met behulp van open vragen.

Veronderstellingen voor mogelijke effecten, of de afwezigheid daarvan, zijn schaars. In de literatuur zijn slechts enkele hypothesen te vinden die aanduiden waarom student begeleid door student-docenten even hoog of beter scoren dan studenten begeleid door staf-docenten. De eerste hypothese gaat uit van de gedachte dat de afwezigheid van een staflid-docent in een groep ertoe leidt dat de studenten meer en beter met elkaar communiceren over de leerstof. Uit sommige studies blijkt dat docenten vaak meer dan de helft van de spreektijd die beschikbaar is tijdens groepsdiscussies in beslagnemen. De studenten kunnen in een dergelijke situatie hun ideeën en opvattingen wellicht nauwelijks verwoorden. Wanneer echter studenten elkaar daadwerkelijk moeten onderwijzen, bijvoorbeeld doordat de docent zich terughoudend opstelt of zelfs afwezig is, moeten de leden van de discussiegroep elkaar echt helpen door informatie uit te wisselen. Verondersteld wordt dat deze activiteit tot elaboratie van het kennisbestand leidt. Hierdoor beklijft de informatie beter. De tweede hypothese die in de literatuur aangetroffen wordt, berust op het vermoeden dat de kennisstructuur van de student-docent sterk lijkt op de 
kennisstructuur van zijn medestudenten. De student-docent zou daardoor het kennisniveau en de problemen die de studenten hebben met de leerstof beter kunnen inschatten en hierop gemakkelijker kunnen aansluiten. De onderlinge informatie-uitwisseling zou hierdoor duidelijker en effectiever verlopen. Ook deze verklaring voorspelt dus geen verschillen in leerprestaties. De derde hypothese gaat uit van de idee dat studenten, in een onderwijscontext waarin zij begeleid worden door medestudenten, meer gemotiveerd raken voor hun studie. De begeleidende ouderejaarsstudenten zouden zich gemakkelijker kunnen verplaatsen in de leefwereld van hun medestudenten dan stafleden. Ze zouden zich relatief gemakkelijk een beeld kunnen vormen van de moeilijkheden en mogelijkheden die hun medestudenten hebben met hun studie en daarop meer adequaat kunnen inspelen met suggesties tot verbetering gebaseerd op hun eigen recente studie-ervaringen. Door dichter aan te sluiten bij hun opvattingen, normen en waarden kunnen ouderejaars jongerejaarsstudenten gemakkelijker motiveren door te zetten met hun studie.

In dit proefschrift wordt een additionele veronderstelling met betrekking tot het ontbreken van verschillen in leerprestaties geuit en onderzocht. Deze hypothese is dat studenten begeleid door student-docenten compensatie zoeken voor de relatief zwakkere begeleiding van medestudenten door harder te studeren dan studenten begeleid door stafleden. Interessant is dat in de literatuur geen veronderstellingen zijn te vinden waarom in sommige studies studenten begeleid door docenten het bij de prestatiemeting beter doen. In dit profschrift wordt hiervoor de volgende hypothese aangereikt: docenten beschikken over meer kennis en didactische ervaring dan student-begeiders. Hierdoor verloopt het proces van kennisoverdracht beter. Studenten begeleid door docenten leren daardoor meer en scoren op de toets hoger dan studenten begeleid door medestudenten.

In het onderzoek dat in dit proefschrift gepresenteerd wordt, zijn enkele van bovenstaande veronderstellingen nader onderzocht. Eerst is nagegaan of er verschillen in leerprestaties optreden tussen studenten begeleid door student-tutoren en studenten begeleid door staf-tutoren. Vervolgens is bestudeerd of er verschillen in studie-inspanning zijn tussen studenten in beide condities. Daarna is onderzocht of, en op welke aspecten, het optreden van student-tutoren verschilt van dat van staf-tutoren wanneer zij een groep begeleiden. Ten slotte is onderzocht of er relaties gelegd kunnen worden tussen specifieke kenmerken van docentgedrag en de uitkomsten in tijdsbesteding en leerprestaties.

Hoofdstuk 3 beschrijft de wijze waarop het onderzoek is uitgevoerd. Het onderzoek betrof een veldexperiment dat plaatsvond in het eerste cursusjaar van de studie Nederlands Recht. Het onderzoek werd in twee verschillende onderwijsblokken uitgevoerd: de blokken "Rechtshandeling" en "Onrechtma- 
tig gedrag". Tijdens beide blokperioden werden eerstejaarsstudenten aselect toegewezen aan een experimentele conditie (begeleiding door student-tutoren) of een controle conditie (begeleiding door docent-tutoren). Tutoren werden eveneens aselect toegewezen aan de onderwijsgroepen. Om verschillen in leerprestaties op te kunnen sporen werd na afloop van ieder blok aan de deelnemers, onder examencondities, een kennistoets bestaande uit 5 essayvragen voorgelegd. Om verschillen in tijdsbesteding, te kunnen onderzoeken (nodig vanuit de veronderstelling dat studenten begeleid door studenten feitelijk compenseren door harder te werken) vulden de studenten tijdens elke onderwijsperiode een studietijdregistratieformulier in. Om verschillen in tutorgedragingen na te kunnen gaan, vulden de groepsleden tijdens de laatste week van ieder onderwijsblok een vragenlijst in waarin hen een oordeel gevraagd werd over het functioneren van hun tutor en over enkele andere aspecten van het onderwijs dat zij in de desbetreffende blokperiode ontvangen hadden. Tevens werden in de laatste weken van ieder blok aselect gekozen studenten geïnterviewd over het functioneren van hun tutor.

In Hoofdstuk 4 wordt verslag verslag gedaan van een studie naar verschillen in leerprestaties tussen studenten begeleid door staf-tutoren en studenten begeleid door student-tutoren. Aangenomen werd dat de studenten begeleid door de staf-tutoren beter zouden scoren op de prestatiemeting. Deze hypothese werd gebaseerd op de veronderstelling dat de staf-tutoren over meer vakinhoudelijke deskundigheid beschikken dan student-tutoren. Meting van de voorkennis van de studenten voorafgaande aan beide onderwijsblokken toonde aan dat er geen verschillen in voorkennis was tussen de studenten in beide condities. De resultaten in beide onderwijsperioden toonden aan dat studenten begeleid door staf-tutoren vergeleken met de student-tutoren niet significant verschilden. Het onderzoek naar de leerprestaties met behulp van de eindtoets had echter drie beperkingen. Ten eerste bestond de eindtoets slechts uit vijf essayvragen, waardoor niet alle onderwerpen die tijdens de blokperiode aan de orde gesteld waren geëxaminieerd werden. Ten tweede werden de antwoorden per vraag slechts door één beoordelaar nagekeken. De betrouwbaarheid van de oordelen was daarom laag. Ten derde zou de gevolgde beoordelingsprocedure onvoldoende sensitief kunnen zijn om feitelijke verschillen tussen de studenten in beide condities aan het licht te brengen. Om dit laatste bezwaar te ondervangen werd een deel van de antwoorden van de studenten achteraf nogmaals zorgvuldig nagekeken en werden beide onderzoekspopulaties weer met elkaar vergeleken. Daarvoor werd de methode van propositie-analyse gebruikt. Ook met behulp van deze meer analytische en meer betrouwbare methode werden geen verschillen van betekenis gevonden. Op grond van dit onderzoek werd geconcludeerd dat studenten begeleid door staf-tutoren geen betere leerprestaties leveren dan studenten begeleid door 
student-tutoren. In de volgende hoofdstukken van dit proefschrift is geprobeerd een verklaring te vinden voor de afwezigheid van verschillen in studieprestaties.

In Hoofdstuk 5 wordt verslag gedaan van een onderzoek naar verschillen in studie-inspanning tussen studenten begeleid door student- of staf-tutoren. Centraal stond de veronderstelling dat studenten in de studentgeleide groepen een mogelijk relatief tekort aan overzicht en diepgang bij hun begeleiders proberen te compenseren door meer tijd aan zelfstudie te besteden. Op verschillende wijze werd nagegaan of er inderdaad verschillen in vakinhoudelijke deskundigheid bestond tussen de student- en staf-tutoren. Aan de tutoren werd voorafgaande aan het blok waarin zij optraden een toets voorgelegd (de zogenoemde "objectieve kennismeting"), tevens werd er aan hen gevraagd aan te geven in welke mate zij zich meer of minder deskundig achtten met betrekking tot de verschillende onderwerpen die in het blok aan de orde komen (de zogenoemde "subjectieve kennismeting"). Wat de objectieve kennismeting betrof bleek dat in het blok "Rechtshandeling" er geen verschil in kennis geconstateerd kon worden, in het blok "Onrechtmatig gedrag" daarentegen werd wel een significant verschil geconstateerd. Staf-tutoren bleken in laatstgenoemde blok over meer vakinhoudelijke kennis te beschikken dan student-tutoren. Wat de subjectieve kennismeting betrof bleken de staf-tutoren zich in beide blokken niet deskundiger te achtten dan de student-tutoren. Ook aan de studenten werd gevraagd in te schatten hoe deskundig hun tutor was. De resultaten daarvan waren dat de studenten in beide blokken van mening waren dat de student-tutoren als minder deskundig beoordeeld werden dan de staf-tutoren. Geconcludeerd werd dat in de waarneming van de studenten in ieder geval sprake was van een verschil in deskundigheid. Dat verschil zou, zo werd verondersteld, kunnen leiden tot compensatiegedrag bij studenten begeleid door student-tutoren.

Om na te gaan of studenten begeleid door student-tutoren meer tijd gebruiken aan zelfstudie werd gebruik gemaakt van een tijdschrijfmethode, waarbij de studenten dagelijks bijhielden hoeveel tijd zij aan hun studie besteed hadden. De studenten vulden dagelijks op een tijdschrijfformulier in hoeveel tijd zij besteedden aan zelfstudie voor en deelname aan de verschillende onderwijsactiviteiten die in het blok georganiseerd werden. De formulieren werden wekelijks uitgedeeld en opgehaald. De resultaten verkregen in de onderwijsblokken "Rechtshandeling" en "Onrechtmatig gedrag" verschilden. In eerstgenoemde blokperiode besteedden de studenten begeleid door de student-tutoren, zoals verondersteld, significant meer tijd aan zelfstudie dan de studenten begeleid door de staf-tutoren. In de daarop volgende blokperiode werden echter geen verschillen gevonden tussen beide condities. De veronderstelling dat studenten begelcid door student-tutoren compenseerden voor ver- 
onderstelde relatieve kennisachterstand van hun begeleider door harder te studeren, is dus niet systematisch bevestigd en heeft slechts een beperkte betekenis.

Hoofdstuk 6 rapporteert onderzoek naar verschillen in optreden van studenttutoren en staf-tutoren. Om na te gaan of ouderejaarsstudenten de tutorrol inderdaad op een andere wijze vervullen dan stafleden, zoals in Hoofdstuk 2 verondersteld werd, werd een observatielijst over het functioneren van tutoren geconstrueerd. Deze observatielijst werd aan de studenten voorgelegd. Er werd dus aandacht besteed aan het feitelijk gedrag van de tutor zoals dat door de studenten gepercipieerd werd. In het functioneren van de tutor werden twee hoofdcomponenten onderscheiden: de wijze waarop de tutor omgaat met de kennis die door de studenten verworven moet worden en de wijze waarop de tutor een relatie met de leden van de onderwijsgroep opbouwt. Binnen de eerste component, die de kenniscomponent genoemd werd, werden drie elementen onderscheiden: "expertise gebruik", de mate waarin de tutor zijn vakinhoudelijke expertise gebruikte, "cognitieve congruentie" de mate waarin de tutor in staat was zich in te leven in de denkwereld van de studenten en "toetsorientatie" de mate waarin de tutor in zijn handelen gebruik maakte van het feit dat iedere blokperiode afgesloten werd met een summatieve toets. De tweede component, die de relatiecomponent genoemd werd, werd evencens onderscheiden in een aantal elementen: "autoriteit", de mate waarin de tutor gebruik maakte van zijn gezag, "rolcongruentie" de mate waarin de tutor zich inleefde in en open stond voor de leefwereld van de studenten en "aandacht voor samenwerking" de mate waarin de tutor gericht was op het begeleiden van de samenwerking in de groep. Voorafgaande aan het onderzoek werden de volgende hypothesen geformuleerd. Verwacht werd dat de staf-tutoren meer gebruik zouden maken van hun expertise en meer autoriteit zouden uitoefenen ten opzichte van de studenten dan de student-tutoren. Verwacht werd dat de student-tutoren beter in staat zouden zijn zich in te leven in de denken leefwereld van de studenten en dat de student-tutor in zijn handelen meer gericht zou zijn op de bloktoets en meer aandacht zou besteden aan de samenwerking van de onderwijsgroepsleden dan de staf-tutoren. Voor alle dimensies werden items ontwikkeld, gebaseerd op interviewverslagen met studenten en tutoren, observaties in onderwijsgroepen, literatuur over tutorgedrag en eerder onderzoek naar tutorfunctioneren. Betrouwbaarheid en constructvaliditeit van de ontwikkelde beoordelingsschalen bleken bevredigend hoog te zijn.

Het onderzoek naar verschillen in gedrag tussen student-tutoren en staftutoren vond eveneens plaats in de blokken "Rechtshandeling" en "Onrechtmatig gedrag". Aan het einde van elk blok vulden alle studenten de vragenlijst in. De resultaten bevestigden in grote mate de veronderstellingen. Staf- 
tutoren gebruikten hun expertise sterker dan student-tutoren. Hoewel dit resultat in beide blokken geconstateerd werd, waren de verschillen slechts in het blok "Onrechtmatig gedrag" significant. Significante verschillen met betrekking tot de wijze waarop de staf en student-tutoren zich opstelden ten opzichte van de studenten (autoriteit) werden in beide blokken aangetroffen. Ook de hypothesen met betrekking tot cognitieve congruentie, rolcongruentie en toetsoriëntatie werden in beide blokken bevestigd. Student-tutoren waren beter in staat zich in te leven in de denk- en leefwereld van de onderwijsgroepsleden die zij begeleiden dan de stafleden. Tevens maakten de studenttutoren bij hun sturing van de activiteiten van studenten in de onderwijsgroep meer gebruik van het feit dat de resultaten van de bloktoets summatief zijn dan de staf-tutoren. De gevonden verschillen in deze domeinen waren significant en relatief groot. Geen verschillen werden gevonden wat betreft de aandacht van staf- en student-tutoren voor de samenwerking van de leden van de onderwijsgroep. De gegevens verkregen uit deze studie bevestigden de veronderstelling dat student-tutoren onderwijsgroepen op een andere wijze begeleiden dan staf-tutoren. Uit de resultaten dringt zich een beeld naar voren dat student-tutoren een beter idee hebben van de problemen die eerstejaarsstudenten hebben met het begrijpen van de leerstof en de eisen die aan het leren van deze studenten gesteld worden bij hun intrede in het hoger onderwijs. Doordat ze beter in staat zijn "de taal van de studenten" te spreken lijken ze ook beter in staat de leden van hun onderwijsgroep oplossingen aan te reiken die door de eerstejaars begrepen kunnen worden. Staf-tutoren daarentegen lijken het leer- en studieproces van de studenten relatief wat meer op een afstand te begeleiden. Waarschijnlijk hangt dit samen met het feit dat hun beeld van de wijze waarop zij indertijd hun studie beleefd hebben al enigermate vervaagd is. Ze kunnen zich blijkbaar niet meer zo goed een beeld vormen van de problemen die de studenten hebben. Bij hun optreden in de onderwijsgroep stellen ze zich ook sneller meer corrigerend op naar datgene wat studenten in de onderwijsgroep naar voren brengen. Daarbij laten ze hun goed- of afkeuring over de inbreng van de groepsleden nogal duidelijk blijken. Deze waardeoordelen beïnvloeden de mate waarin studenten zich vrij voelen om aan de discussie in de groep deel te nemen.

In Hoofdstuk 7 wordt de veronderstelling geuit dat effectief tutorfunctioneren niet in de eerste plaats een kwestie is van de vraag of de tutor een staflid of een student is, maar van de vraag of die student of dat staflid bepaalde activiteiten onderneemt, gedragingen vertoont, die effectief zijn. De vraag die in dit Hoofdstuk gesteld werd was: zijn bepaalde gedragingen, los van de vraag of ze door een student dan wel een staflid worden vertoond, causaal verantwoordelijk te stellen voor de prestatie van de studenten? Aansluitend bij een causaal model van probleemgestuurd onderwijs werd nagegaan wat de samen- 
hang en invloed was van de wijze waarop de tutor zijn expertise gebruikt, de wijze waarop de tutor zich opstelt ten opzichte van de studenten in de onderwijsgroep, de mate van cognitief congruent gedrag van de tutor, en het functioneren van de studenten in de onderwijsgroep, de hoeveelheid tijd besteed aan zelfstudie, de mate waarin studenten geïnteresseerd raken in de leerstof en de leerprestaties. In het model werd een centrale rol toebedeeld aan het begrip cognitieve congruentie van de tutor. Wil een tutor het leren van de studenten in en door het gesprek in de onderwijsgroep faciliteren dan zal hij zich moeten kunnen verplaatsen in de denkwereld van de studenten. Hij zal zijn stimuli om het leren te bevorderen, bijvoorbeeld de vragen die hij stelt of de uitleg die hij geeft, op het denkniveau van de studenten moeten kunnen afstemmen. De tutor moet zich kunnen uitdrukken in een taal die de studenten begrijpt. Verondersteld werd dat cognitieve congruentie van de tutor het functioneren van de onderwijsgroep verbetert en dat dat op zijn beurt de leerprestaties en de motivatie van de studenten bevordert. Cognitieve congruentie op zijn beurt wordt weer beïnvloed door kennis van het vakgebied van de tutor en sociale congruentie. Sociale congruentie werd omschreven als het vermogen van de tutor om een persoonlijke verstandhouding aan te gaan met de student en het vermogen om de studenten ruimte te geven om zelf invulling te geven aan hun leren. Voor een visuele wecrgave van het model zij de lercr verwezen naar Figuur 7.2.

Via de methode van structurele vergelijkingen werd bovengeschetst model getest. De resultaten van de padanalyse toonden aan dat het model goed "paste". De expertise die de tutor heeft en de mate waarin hij zich kan verplaatsen in de leefwereld van de studenten beïnvloeden in redelijke mate cognitieve congruentie. Cognitieve congruentie heeft een sterke positieve invloed op het functioneren van de onderwijsgroep. Dit betekent dat, naarmate een tutor zich beter kan verplaatsen in de denkwereld van de studenten en aansluitend daarop zijn leerbevorderende bijdragen geeft, de onderwijsgroep beter functioneert. Het functioneren van de groep bleek de prestatie te beinvloeden (zij het niet op statistisch significante wijze).

Op grond van deze resultaten wordt het hoofdstuk besloten met een beschrijving van enkele consequenties die deze uitkomsten kunnen hebben voor het inzetten van en de begeleiding van tutoren. Voorgesteld wordt dat in de onderwijsblokken alleen tutoren toegelaten worden die beschikken over een voldoende mate van vakinhoudelijke deskundigheid. Ook dienen tutoren kort na afloop van een blokperiode door middel van studentenquêtes feedback te krijgen. Deze feedback moet betrekking hebben op hun optreden in de onderwijsgroep, de leerprestaties en de tijd besteed aan zelfstudie van de onderwijsgroepsleden en de gemiddeldes van de jaargroep. Het functioneren als tutor dient bovendien deel uit te maken van de personeelsbeoordeling van de medewerker. Bij de begeleiding van tutoren moet meer rekening worden gehouden met het feit dat cognitieve en sociale congruentie zo'n sterke invloed 
heeft op het leren van de studenten in de onderwijsgroep. Tijdens de cursussen die voor tutoren georganiseerd worden, moet vooral aandacht besteed worden aan de wijze waarop studenten kunnen helpen de leerstof te begrijpen en toe te passen. Een centrale rol wordt daarbij toegekend aan de blokgebonden tutorbijeenkomsten. Daarin kunnen tutoren van elkaar leren op welke wijze zij de problemen, waarop de studenten stuiten, benaderen en proberen op te lossen. 
In 1982, the Faculty of Law at the University of Limburg established a curriculum founded on the principles of problem-based learning. Problembased learning is a process in which students gain knowledge by discussing problems in small-group tutorials. The groups are guided by a tutor, usually a member of the teaching staff.

In the academic year 1985-1986 the Faculty was, quite unexpectedly, confronted with large numbers of students. Consequently, the teaching staff faced the problem of insufficient numbers of staff tutors in relation to the number of tutorial groups. The question arose whether one of the fundamental principles of problem-based learning, i.e. small-scale groups, could be maintained. One of the suggestions to preserve this principle involved the use of undergraduate students as tutors. After full consideration, the Faculty decided to conduct this experiment. Initially, the Faculty believed that these students met with the requirements. However, doubts concerning students as tutors developed after some research in one course. After reviewing end-ofterm exams, it appeared that students guided by undergraduates did not achieve as high as those guided by faculty members. Based on this finding the Faculty decided to thoroughly investigate the performance of undergraduate students compared to staff members in the role of tutor. Their goal was to investigate whether they differ in facilitating the students' learning process and whether their performance leads to different study results.

The research presented in this thesis investigates the following questions. First, whether academic performance of students guided by staff tutors differs from academic performance of students guided by student tutors. Second, whether study efforts of students in both conditions are similar. Third, whether the performances of the staff and student tutors differ. And, finally, 
whether a relationship can be found between specific characteristics of tutor behavior, academic performance and the time students spent on their studies.

Chapter $l$ gives an overview of how the problem-based learning process is arranged in the Faculty of Law. After a short description of several educational approaches from which problem-based learning has been evolved, special attention is given to how students and tutors are involved in gaining knowledge by the problem-based-leaming method.

One of the main characteristics of problem-based learning is the strong emphasis on students' self-directedness. The first step to stimulate students' activity is to have them analyze a series of carefully constructed problems. This analysis takes place in a small group of ten students; the so-called small-group tutorial. The objective of the group members is to discuss these problems, to identify the relevant issues and to produce tentative explanations. After an initial brainstorm and after considering everyone's ideas, the students formulate learning objectives. These objectives are based on gaps in knowledge, dilemma's and questions they encounter during this analysis. The next step they must undertake is individual study. Within a two-day period students study legal texts, look for audio-visual materials and consult faculty members to gain a better understanding of the diverse aspects of the problem. After this period of self-directed study, students return to their group for the final step in the process. They discuss and exchange the information gathered in their study and try to apply their newly acquired knowledge to the problem-at-hand.

These phases of problem-analysis, formulating learning objectives, individual study, synthesis and applying the acquired knowledge, do not always proceed smoothly. First, as a novice entering into a new field of study, the students have vague ideas about which explanations are appropriate for certain problems. Consequently, their discussion can be rather superficial. Second, group members formulate leaming objectives that are too broad and unspecified, thus hindering their individual study. third, problems can also arise in the phase of synthesis. For example, students either insufficiently discern the coherence within the subject-matter or have difficulty applying what they have just learned. Moreover, they are unable to summarize in broad outlines the differences and similarities of the several topics connected with the theme of the course. Last, internal groupcooperation can be impeded by communication problems which threaten its cohesion, task performance and atmosphere.

To help the members of the small-group tutorials gain knowledge, every group is guided by a faculty member, the so-called tutor. The tasks of the tutor are twofold: to support the students in acquiring knowledge and exchanging information, and to stimulate their collaboration. For example, the 
tutor can help the students find the connection between different parts of the course. He can assist the group in formulating clear and manageable learning objectives. He can ask probing questions to stimulate discussion. And, if necessary, he can contribute by giving subject-matter information, as well as helping students evaluate their progress. Moreover, he can give them positive feed-back about the way the chairman and group members communicate with one another, encourage silent members and foster group development. Salient in the performance of a tutor is facilitating the students' learning as opposed to direct teaching. A tutors' activity must support students' autonomy.

The question whether undergraduate students differ from staff teachers in their performance is not at all new. Therefore, Chapter 2 presents a review of past research and possible hypotheses on efficient learning experiences where students perform the role of 'teacher'. The outcomes of peers teaching peersresearch are contradictory. For example, some studies report better achievement for staff guided students, some reveal no differences, and others show that student-guided students perform better on end-of-course exams. Several methodological explanations are considered for these inconsistent outcomes; differences in the classrooms' didactic approaches, differences in the magnitude of the groups studied and differences in the manner of assessing students' achievement. Some of the research, for instance, used multiple choice questions to judge students' academic performance, while other research used essay questions.

Hypotheses for possible effects or their absence of peer-guided teaching are feeble. In the literature, several hypotheses can be found which indicate why students guided by student teachers perform as well as or even better than students guided by staff teachers. A first assumption is that the absence of a teacher in a discussion group enables students to discuss more freely with each other about issues. Some studies have shown that teachers usually claim half or more of the talking time. By consuming so much time, students are hardly able to express their ideas. However, in discussion groups where students have to teach themselves, because the teacher is either absent or withdraws himself from the discussion, the members of the group actually benefit from helping one another. The assumption is that this activity expands their knowledge. By doing so information will be more easily remembered. The second premisse is founded on the idea that the knowledge structure of the student-teacher is more comparable to the knowledge structure of the students he guides. Because his knowledge is relatively at the same conceptual level as that of his peers, the student-teacher will often refer to linking concepts, relationships and facts that are part of the learners' knowledge. As a result, the process of information exchange is more supportive. The third hypothesis is based on the idea that students taught in a 
context in which they are guided by peer-tutors, become more motivated to leam. Moreover, because peer tutors interact rather in a directly and personally way with the students, a safer and more secure learning environment is created. In addition to these hypotheses found in the literature a fourth assumption will be researched in this thesis. It is assumed that students guided by student-teachers will compensate for their tutors' relative lack of expertise by working harder during their individual study than students guided by staff teachers.

Chapter 3 describes how the research is done. It concerns a field experiment in the first year curriculum of the Law Faculty. Two course units were studied; "legal transactions" and "unlawful behavior". In both eight week courses students were randomly selected to participate in either the experimental condition (tutorial groups guided by student tutors) or the control condition (tutorial groups guided by staff tutors). Student and staff tutors also were assigned at random to the tutorial groups. To discover differences in achievement, all students had to take an exam under normal test-taking conditions. To investigate differences in their study effort students filled out a study time registration form every day. This was necessary to test the above mentioned hypothesis that students guided by students try to compensate for their tutors' relative lack of content expertise by working harder. To find out possible differences in tutor behavior students had to complete a questionnaire in which they were asked to give their opinion about the performance of their tutor and about some other aspects of the course. This was done in the last week of every unit. Additionally, students of tutorial groups were interviewed about their tutors' performance.

Chapter 4 reports the study on differences in academic performance of student-guided and staff-guided students in both courses. It was assumed that students supported by staff tutors would perform better on the achievement test. The hypothesis was that staff tutors would have more content expertise than student tutors. After all, staff tutors would be better equiped to help their students in analyzing and synthesizing the subject-matter. Once prior knowledge had been assessed, no differences appeared between students in the experimental condition and students in the control condition. The end-of-term results in both courses showed no differences between students guided by either student or staff tutors. However, their achievement on the end-ofcourse test had some pitfalls. First, the end-of-course test only had five essay questions, so it is possible that not all subjects covered during the course were examined. Second, the answers to every question were judged by only one teacher. Therefore, the reliability of the judgement was rather low. Third, 
judging procedure might have been insensitive in showing the differences of students' performance in both conditions. To solve this problem an andom sample of the answers of students was carefully screened by means of another assessment procedure; the so-called method of propositional analysis. Even with this more analytical and reliable method no differences between either conditions were found. The results of each assessment procedure suggest that staff tutors provide no better guidance to tutorial groups than student tutors. However, the question still remains: Why do students guided by student tutors, who have not as much content expertise as staff tutors, perform as well as students guided by staff tutors? In the next chapter we try to give an explanation for this phenomenon.

Chapter 5 researches the differences in study effort of students in both conditions. The hypothesis was that students guided by student tutors compensate for a relative lack of expertise from their tutor by spending more time on individual study. Differences in expertise between staff and student tutors were assessed in various ways. At the beginning of the course, tutors were asked to fill out a test which assessed their content expertise (the socalled objective measurement test). They were also asked to indicate on a scale how much expertise they thought they had with regard to the different subjects offered in the course (the so-called subjective measurement test). According to the objective test no differences were found between staff and student tutors in the "legal transactions" course. However, staff tutors in the "unlawful behavior" course scored significantly higher than student tutors. With respect to the subjective measurement test no differences were found in either course.

Students were also asked to estimate their tutors' expertise. In both courses they indicated that student tutors had less knowledge about the topics than staff tutors. It was concluded that the students perceived a difference in expertise. According to the hypothesis that difference would initiate compensatory behavior of students guided by student tutors.

To test this hypothesis all students were asked to record every day how much time they spent on individual study and attendance of curriculum activities. The outcomes of study efforts in "legal transactions" and "unlawful behavior" differed. In the first course students guided by student tutors spent, as hypothesized, significantly more time on individual study than those guided by staff tutors. In the other course, however, no differences were found. Therefore, the hypothesis that students compensate for a supposed relative lack of knowledge from their student tutor by spending more time on individual study, is only of limited significance. 
The question concerning an explanation for the lack of differences in achievement still exists. In the next chapter we try to find an answer to this question by proposing the hypothesis that tutors differ in performance.

Chapter 6 studies the question whether student tutors perform their role in the same or in a different manner than staff tutors. A questionnaire about tutor performance was devised to show the actual behavior of the tutor as observed by the students. Two main components of the tutor role could be discerned: The way a tutor handles the knowledge students must acquire, and the way a tutor establishes a personal relationship with the members of the group. Within the first component, the so-called knowledge component, three different elements were distinguished. First, "use of expertise"; to what extent a tutor uses his subject matter expertise to help students. Second, "cognitive congruency"; to what extent a tutor is able to identify with students on their own level when processing information. Third, "assessment orientation"; to what extent a tutor stresses the end of course test to direct the students' learning performance.

The other main component, the so-called relationship component, also includes three elements. First, "authority"; to what extent a tutor exercises his power to direct students' behavior in the group. Second, "role congruency"; to what extent a tutor is able to empathize with and relate to students' life experience. Third, "focus on cooperation"; to what extent a tutor is interested in the cooperation process in the group.

Several hypotheses about student and staff tutors' performance were formulated. It was expected that staff tutors would use their expertise and authority more frequently than student tutors. On the other hand, it was expected that student tutors would be better able to empathize with students' level of processing information and their life experiences. It was also thought that student tutors would be more assessment-oriented and would be more focussed on the cooperation in the group. For all elements items were developed, on the basis of interviews with students and tutors, observations in tutorial groups, literature on teacher behavior and previous research on tutor performance. Reliability and constructvalidity of the diverse elements were shown to be satisfactorily high.

The research into the differences between student and staff tutors' performance was also done in the courses "legal transactions" and "unlawful behavior". At the end of both units students answered the questionnaire. The outcome confirmed the hypotheses for the most part. Staff tutors used their expertise more often than student tutors. Although this outcome was found in both courses, only the results in the course "unlawful behavior" showed significant differences. Further, differences were found, in both units, with respect to tutors' authority. Staff tutors exhibited more authoritarian behavior 
than student tutors. The outcomes concerning cognitive congruency as well as role congruency were also in line with the assumptions. Both courses showed that student tutors were better at understanding the nature of the problems students faced in attempting to master the subject-matter. Student tutors were also more interested in students' daily lives, study experiences and personalities. All differences were significant and relatively large. Signiticant differences were also found with regard to assessment orientation. Student tutors used the end-of-course exam more frequently than staff tutors to direct students activities in the small-group tutorial. Finally, no differences were found with respect to tutors' focus on cooperation between the members of the group.

In conclusion, the outcome of this study seems to affirm the assumption that student tutors guide small-group tutorials in a different way than staff tutors. From these findings, one has the impression that student tutors have a better idea of the problems first-years have in understanding the subjectmatter as well as the demands that an university education requires. Because they are able "to speak the language of the students", they appear more competent to offer the members of their group solutions that first-years can comprehend. Conversely, staff tutors guide the process of learning and studying from a relatively remote distance. Probably, they are unable to visualize the problems students have with knowledge acquisition. During the learning process, staff tutors rapidly correct what students contribute to the discussion. By formulating their approvals and disapprovals in a pedantic manner, staff tutors have a chilling effect on students' participation in the discussions.

Chapter 7 expresses the assumption that effective tutor performance is not really a question whether a tutor is a staff member or an undergraduate student, but rather whether student or staff tutors exhibit behavior that stimulates students'learning. Therefore, the question investigated in this chapter is: Is there a causal connection between tutor behavior and students' achievement. In accordance with a causal model of problem-based learning, the coherence and influence was researched of tutor's use of expertise, his social and cognitive congruency, the groups' performance, students' time on self-study, motivation and achievement. In the model a central role was assigned to cognitive congruency. To facilitate students' learning a tutor must identify with students' thinking process. His ability to help students is manifested by using a terminology adapted to their level of competence. The tutor must be able to ask questions and give explanations in a language students can understand. It was presumed that cognitive congruency of a tutor improves the performance of the small-tutorial group. After all, a better functioning tutorial group should support students' motivation and achievement. Besides this, it was presumed that cognitive congruency would be influenced by tutor's ex- 
pertise and social congruency. Social congruency was defined as a tutor's interest in their students' daily lives and personalities on a personal, nonauthoratative level. Figure 7.2 shows a visual representation of the model.

The model was tested by the method of structural equations. The outcome of the padanalysis showed that the model "applied" quite well. Appropriate knowledge and social congruency were causally responsible for the emergence of cognitive congruency. Cognitive congruency also exerts a strong influence on group functioning. This means that the better a tutor empathizes with students' thoughts and adapts his interventions to their level of understanding, the better the group performs and the better the results of students are. Group performance influenced academic achievement (however, not in a statistically significant way).

On the basis of these results, the chapter concludes with some recommendations for instructional development, especially the selection and training of tutors. With respect to selection several procedures are suggested. The first one is to give only tutors with an adequate level of content expertise an opportunity to be a tutor. The second suggestion concerns feedback. Shortly after the end of a course, a tutor should be informed about his performance in the tutorial group, the achievement of his students and their amount of time spent on self-study. This should be compared to the averages of his colleagues that were also tutoring in that unit. The third suggestion concerns recruitment policy. The performance of tutors should also been part of the faculty's promotion and tenure.

With respect to the training of tutors, more attention should be given to cognitive and social congruency. After a general introductory workshop on the tutor role coursebound tutortraining should follow. On-the-job training such as working with the actual problems to be presented to the students, would give tutors a better idea of the specific cognitive problems students will encounter. By informing each other how they try to help students solve these problems, tutors can gain a broader range of possible interventions which might effectively stimulate student elaboration and cognition. 
Abercrombie, M.L.J. (1979). Aims and techniques of group teaching. (4th ed.). Guilford: Society for Research into Higher Education.

Ahmann, J.S., \& Glock, M.D. (1971). Evaluating student progress. Principles of tests and measurements. Boston: Allyn and Bacon.

Alblas, G. (1983). Groepsprocessen. Het functioneren van taakgerichte groepen. Deventer: Van Loghem Slaterus.

Alexander, L.T., Gur, R., Gur, R., \& Patterson, L. (1974). Peer assisted learning. Improving Human Performance Quaterly, 3, 175-186.

Allen, A.R., \& Boraks, N. (1978). Peer tutoring: Putting it to the test. The Reading Teacher, 32, 274.

Allen, V.L. (1976). Children as teachers. Theory and research on tutoring. New York: Academic Press.

Anderson, J.C., \& Gerbing, D.W. (1984). The effects of sampling error on convergence, improper solutions and goodness-of-fit indices for maximum likelihood confirmatory factor analysis. Psychometrica, 53, 155-173.

Anderson, J.R., \& Reder, L.M. (1979). An elaborative processing explanation of depth of processing. In S. Cermak \& F.I.M. Craik (Eds.), Levels of processing in human memory. Hillsdale: Lawrence Erlbaum.

Annis, L.F. (1983). The processes and effects of peer tutoring. Human Learning, 2, 39-47.

Bargh, J.A., \& Schul, Y. (1980). On the cognitive benefits of teaching. Journal of Educational Psychology, 72, 593-604.

Barrows, H.S. (1985) How to design a problem-based curriculum for the preclinical years. New York: Springer Publ. co.

Barrows, H.S. (1988). The tutorial process. Springfield (Ill.): Southern Illinois University School of Medicine.

Beach, L.R. (1974). Self-directed student groups and college leaming. Higher Education, 3, $187-200$.

Beach, L.R. (1983). A report from America. In K.G. Collier (Ed.)., The management of peer group learning. Syndicate methods in Higher Education. (pp. 48-55). Guilford: Society for Research into Higher Education.

Bender, W. (1983). Studenten de mond gesnoerd door autoriteit? Bulletin Medisch Onderwijs, 2, 8-9.

Bentler, P.M. (1985). EQS. Structural equation program manual. L.A. (Cal.) BMDP Statistical software. 3e druk.

Bentler, P.M. (1990) Comparitive fit indexes in structural models. Psychological Bulletin, $107,2,238-246$

Bereiter, C., \& Scardamalia, M. (1989). Intentional learning as a goal of instruction. In: L.B. Resnick (Ed.) Knowing, learning and instruction - Essays in honour of Robert Glaser. (pp. 361-392). Hillsdale, NJ: Erlbaum.

Bloxom, B., Caul, W.F., Fristoe, M., \& Thomson, W.J. (1975). On the use of student-led discussion groups. The Educational Forum, 39, 223-230.

Blunt, M.J., \& Blizzard, P.J. (1973). Development and initial assessment of a teachinglearning programme in anatomy. British Journal of Medical Education, 7, 244-250. 
Boomsma, A. (1983). On the robustness of Lisrel (maximum likelihood estimation) against small sample size and non-normality. Groningen: dissertatie.

Bransford, J.D., \& Johnson, M.K. (1972). Contextual prerequisites for understanding: Some investigations of comprehension and recall. Journal of Verbal Learning and Verbal Behavior, 11, 717-726.

Brennan, R. (1983). Elements of generalizability theory. Iowa: American College Testing program.

Bruner, J.S. (1961). The art of discovery. Harvard Educational Review, 31, 21-32.

Carroll, J.B. (1963). A model of school learning. Teachers College Record, 64, 723-733.

Carsrud, A.L. (1979). Undergraduate tutors: Are they useful? Teaching of Psychology. 6, 46-49.

Cate, Th. J. ten (1986). Leren in groepen zonder docent. Academisch proefschrift, Universiteit van Amsterdam.

Cate, Th.J. ten, Tromp, Th.J.M., \& Cornwall, M.G. (1984). De student als docent. Utrecht: Het Spectrum.

Chambers, P. (1983). The six college project. In K.G. Collier (Ed.), The management of peer group learning. Syndicate methods in Higher Education. (pp. 77-87). Guilford: Society for Research into Higher Education.

Clark, C.M., \& Peterson, P.L. (1986). Teachers' thought processes. In M.C. Wittrock (Ed.), Handbook of research on teaching. (pp. 255-296). New York: MacMillan.

Clarke, R. (1983). A new medical school in Australia. In K.G. Collier (Ed.), The management of peer group learning. Syndicate methods in Higher Education. (pp. 34-42). Guilford: Society for Research into Higher Education.

Clement, D.E. (1971). Learning and retention in student-led discussion groups. The Journal of Social Psycholugy, 84, 279-286.

Coffman, W.E. (1971). Essay examinations. In R.L. Thorndike (Ed.)., Educational Measurement. (pp. 271-302). Washington, D.C.: American Council on Education.

Cohen, E.G. (1984). Talking and working together: Status, interaction, and learning. In P. Peterson, L.C. Wilkinson, \& M. Hallinan (Eds.), Instructional groups in the classroom: organization and processes. New York: Academic Press.

Cohen, M.J., \& Crombag, H.F.M. (1978). De nieuwe medische faculteit in Maastricht en de juridische opleiding. Nederlands Juristen Blad, 19, 335-360.

Cohen, P.A., Kulik, J.A., \& Kulik, C.C. (1982). Educational outcomes of tutoring: A metaanalysis of findings. American Educational Research Journal, 19, 237-248.

College van Bestuur, (1979). Schets van een studierichting Nederlands Recht aan de Rijksuniversiteit Limburg. RL. Maastricht.

Collier, K.G. (1966). An experiment in university teaching. Universities Quaterly, 20, 336348.

Collier, K.G. (1969). Syndicate methods: Further evidence and comment. Universities Quarterly: 23, 431-436.

Collier, K.G. (1980). Peer group learning in higher education: The development of higher order skills. Studies in Higher Education, 5, 55-62.

Collier. K.G. (1983). Syndicate methods placed in context. In K.G. Collier (Ed.), The munagement of peer group learning. Syndicate methods in Higher Education. (pp. 313). Guilford: Society for Research into Higher Education.

Cullicr, K.G. (1985). Teaching methods in higher education: The changing scene, with special reference to small-group work. Higher Education Research and Development, 4, 3-27. 
Cornwall, M.G. (1980). Students as teachers: Peer teaching in higher education. Amsterdam: Centrum Onderzoek Wetenschappelijk Onderwijs.

Cronbach, L.J., Gleser, G.C., Nanda H., \& Rajaratnam, N. (1972). The dependability of behavioral measurements: Theory of generalizability of scores and profiles. New York: John Wiley.

Crombag, H.F.M. (1972). De juridische opleiding in de Verenigde Staten. RM Themis, 125-158.

Crombag, H.F.M., Roskam, E.E.Ch., \& Meuwese, W.A.T. (1973). Het meten van studiebelasting. In W.M. van Woerden, T.M. Chang \& C.J.M. van Geuns-Wicgman (Red.) Onderwijs in de maak. (pp. 205-215). Utrecht: Het Spectrum.

Crombag, H.F.M., \& Vos, P. (1982). De invloed van tijdschrijven op studie-inspanning en studieresultaat. Tijdschrift voor Onderwijsresearch, 7, 97-108.

Crombag, H.F.M., Gruijter, D.N.M. de, Ende, P. van de, \& Vos, P. (1980). De nieuwe propedeuse in de Faculteit der Rechtsgeleerdheid: Verslag over het eerste semester. Leiden: Buro Onderzoek van Onderwijs (rapport nr. 20).

Davis, W.K., Naim, R., Paine, M.E., Anderson, R.M., \& Oh, M.S. (1992). Effects of expert and non-expert facilitators on the small-group process and on student pertormance. Academic Medicine, 67, 7, 470-474.

Damon, W., \& Phelps, E. (1989). Critical distinctions among three approaches to peer education. International Journal of Educational Research, 13, 9-21.

Devin-Sheehan, L., Feldman, R.S., \& Allen, V.L. (1976). Research on children tutoring children: A critical review. Review of Educational Research, 46, 3, 355-385.

Dixon, J.R. (1983). Limit enrollment - Or seek altematives. Engineering Education, 74, 84-85.

Edwards, G. (1983). The engineering syndicate study. In K.G. Collier (Ed.), The management of peer group learning. Syndicate methods in Higher Education. (pp. 67-77). Guilford: Society for Research into Higher Education.

Eagle, C.J., Harasym, P.H. \& Mandin, H. (1992). Effects of tutors with case expertise on problem-based leaming issues. Academic Medicine, 67, 7, 465-469.

Everwijn, S.E.M., \& Muggen, G. (1973). Methoden voor het meten van studietijd. In W.M. van Woerden, T.M. Chang, \& L.J.M. van Geuns-Wiegman (Eds.), Onderwijs in de maak. (pp. 216-228). Utrecht: Het Spectrum.

Field, B.O. (1973). A new practical course in inorganic chemistry. In D.E. Billing \& B.S. Furniss (Eds.), Aims, methods and assessment of advanced science education. (pp. 4549). London; Heyden \& Son Ltd.

Fineman, S. (1981). Reflections on peer teaching and peer assessment - an undergraduate experience. Assessment and Evaluation in Higher Education, 6, 82-93.

Fransson, A. (1976). Group centered instruction: Intentions and outcomes. In N. Entwistle (Ed.), Strategies for research and development in higher education. (pp. 44- 64). Amsterdam: Swets \& Zeitlinger.

Gall, M.D., \& Gall, J.P. (1976). The discussion method. In N.L. Gage (Ed.), The psychology of teaching methods. (pp. 166-216). Chicago: University of Chicago Press.

Gelderen, A. van, \& Cate O., ten (1985). Vrijwilligerseffecten in tijdschrijfonderzoek. Tijdschrift voor Onderwijsresearch, 10, 149-160.

Glew, P. (1983). Kinesiology: academic aspects of physical education. In K.G. Collier (Ed.), The management of peer group learning. Syndicate methods in Higher Education. (pp. 42-48). Guilford: Society for Research into Higher Education.

Goldschmid, M.L. (1971). The learning cell: An instructional innovation. Leaming and Development, 2, 1-16. 
Goldschmid, B., \& Goldschmid, M.L. (1976). Peer teaching in higher education: A review. Higher Education, 5, 9-33.

Goldschmid, M.L., \& Shore, B.M. (1974). The learning cell: A field test of an educational innovation. In W.A. Verreck (Ed.), Methodological problems in research and development in higher education. (pp. 218-236). Amsterdam: Swets \& Zeitlinger.

Gijselaers, W.H. (1988). Kwaliteit van het onderwijs gemeten. Academisch proefschrift, RL, Maastricht.

Gijselaers, W.H., \& Schmidt, H.G. (1990). Development and evaluation of a causal model of problem-based learning. In Z.N. Nooman, H.G. Schmidt, \& E.S. Ezzat (Eds.), Innovation in medical education. An evaluation of its present status. (pp. 95-114). New York: Springer Publ. Co.

Gijselaers, W.H., Bouhuijs, P., Mulder, M., \& Mullink, J. (1987) Rapport: Experiment student-tutoren blok 1.5 en blok 1.6. FdEw - OC 87 - 237. RL, Maastricht.

Grave, W.S. de, Volder, M.L. de, Gijselaers, W.H., \& Damoiseaux, V. (1990). Peer teaching and problem-based learning: Tutor characteristics, tutor functioning, group functioning and student-achievement. In Z.N. Nooman, H.G. Schmidt, \& E.S. Ezzat (Eds.), Innovation in medical education. An evaluation of its present status. (pp. 123135). New York: Springer Publ. Co.

Gronlund, N.E. (1976). Measurement and evaluation in teaching. New York: Macmillan.

Gronlund, N.E. (1982). Constructing achievement tests. New York: Prentice-Hall.

Groot, A.D. de (1961). Methodologie. Grondslagen van onderzoek en denken in de gedragswetenschappen. 's-Gravenhage: Mouton.

Gruijter, D.N.M. de (1981). Schatting van de studietijd met matrix sampling. Tijdschrift Onderwijs Research, 6, 209-216.

Hallinan, M.T. (1982). The peer influence process. Studies in Educational Evaluation, 7, 285-306.

Haertel, G.D., Walberg, H.J., \& Weinstein, T. (1983). Psychological models of educational performance: A theoretical synthesis of constructs. Review of Educational Research, $53,75-91$.

Hill, Fawcet Wm. (1969). Learning thru discussion. London: Sage Publications.

Hovey, D.E., Gruber, H.E., \& Terrell, G. (1963). Effects of self-directed study on course achievement, retention, and curiosity. The Journal of Educational Research, 56, 345351 .

Johnson, D.W., Maruyama, G., Johnson, R., Nelson, D., \& Skon, L. (1981). Student achievement on different types of tasks under cooperative, competitive and individualistic conditions. Contemporary Educational Psychology, 4, 99-106.

Jones, B.F. (1991) Thinking and learning: New curricula for the 21th century. Educational Psychologist, 26, 129-143.

Keller, F.S. (1968). Goodbye Teacher ... Journal of Applied Behavior analysis, 1, 79-89.

Knowles, M.S. (1975). Self-directed learning. A guide for leamers and teachers. Chicago: Follet.

Levin, J.R. (1988). Elaboration-based learning strategies: Powerful theory-powerful application. Contemporary Educational Psychology, 13, 191-205.

Levinson-Rose, J., \& Menges, R.J. (1981). Improving college teaching: A critical review of research. Review of Educational Research, 51, 3, 403-434

Lucero, S.M., Jackson, R., \& Galey, W.R. (1986) Tutorial groups in problem-based learning. In A. Kaufman (Ed.) Implementing problem-based medical education. (pp. 4571). New York: Springer. 
Magin, D.J. (1982). Collaborative peer leaming in the laboratory. Studies in Higher Education, 7, 105-117.

Marsh, H.W., Balla. J.R.. \& Mc Donald, R.P. (1988). Goodness-of-fit indexes in confirmatory factor analysis. The effect of sample size. Psychological Bulletin, 103, 391-410.

Mayer, R.E. (1975). Information processing variables in learning to solve problems. Review of Educational Research, 45, 525-541.

Mayer, R.E. (1979). Twenty years of research on advanced organizers. Instructional Science, 8, 133-167.

Mayer, R.E. (1980). Elaboration techniques that increase the meaningfullness of technical text: An experimental test of the leaming strategy hypothesis. Journal of Educational Psychology, 72, 770-784.

Mayer, R.E. (1985). Structural analysis of science prose: Can we increase problem-solving performance? In B.K. Britton, \& J.B. Black (Eds.), Understanding expository text. (pp. 65-87). Hillsdale, Erlbaum Lawrence Ass.

McBean, E.A., \& Al-Nassri, S. (1982). Questionnaire design for student measurement of teaching effectiveness. Higher Education, 11, 273-288.

Mehrens W.A., \& Lehmann, I.J. (1975). Measurement and evaluation in education and psychology. New York: Holt, Rinehart and Winston.

Melaragno, R.J. (1976). Tutoring with students. A handbook for establishing tutorial programs in schools. New Yersey: Englewood Cliffs.

Mellenbergh, G.J. (1971). Studies in studietoetsen. Amsterdam: Universiteit van Amsterdam, dissertatie.

McKeachie, W.J. (1954). Instructional psychology. Annual Review of Psychology, 25, 161 193.

Moust, J.H.C., \& Schmidt, H.G. (1989). Preparing students and faculty for problem-based learning. In H.G. Schmidt, M. Lipkin Jr., M.W. Vries de, \& J.M. Greep, (Eds.), New directions for medical education. Problem-based learning and community-oriented medical education. (pp. 260-271). New York: Springer-Verlag.

Moust, J.H.C., Bakker, R.E., \& Nuy, H.J.P. (1989). De rol van de docent in probleemgestuurd onderwijs. In M.J. Cohen (Ed.), Ervaringen met probleemgestuurd juridisch onderwijs. (pp. 59-71). Groningen: Wolters-Noordhoff.

Moust, J.H.C., Bouhuijs, P.A.J., \& Schmidt, H.G. (1989). Probleemgestuurd leren. Een wegwijzer voor studenten. Groningen: Wolters-Noordhoff.

Moust, J.H.C., Volder, M.L. de, \& Nuy, H.J.P. (1989). Peer teaching and higher level cognitive learning outcomes in problem-based leaming. Higher Education, 18, 737. 742.

Moust, J.H.C., Grave, W.S. de, \& Gijselaers, W.H., (1990) The tutorrole: A neglected variable in the implementation of problem-based learning. In Z.M. Nooman, H.G. Schmidt, \& E.S. Ezzat (Eds.), (pp. 135-152). Innovation in medical education. An evaluation of its present status. New York: Springer Publ. Co.

Nedermeijer, J. (1982). De student in de rol van docent; effectief en goedkoop. In A.G. Vroon (red.), Handboek voor de onderwijspraktijk. (pp. ned 3.4.1 - 3.4.20). Deventer: Van Loghum Slaterus.

Newcomb, T.M. (1974). A conversation with Theodore Newcomb. Psychology Today, sept., 73-80.

Nota Toetsing. Faculteitsbestuur Faculteit der Rechtsgeleerdheid, RL, 1987.

NR-OC, (1984). De inschakeling van student-assistenten in het onderwijs. Nederlands Recht-Onderwijs Commissie-84-I-39. RL, Maastricht.

Onderwijskundige uitgangspunten, FdR Maastricht. NR-OC, (1987). 
OC - 86 - I -52 'Doorgaan, maar beter'. Notitie OC/FdR, RL Maastricht.

OC. 86051/II Reacties op 'Doorgaan, maar beter' Notities OC/FdR RL, Maastricht.

Paolitto, D.P. (1976). The effect of cross-age tutoring on adolescence: An inquiry into theoretical assumptions. Review of Educational Research, 46, 215-237.

Peters, R.S. (1969). Ethics and education. London: Allen and Unwin.

Powell, J.P. (1974). Small group teaching methods in higher education. Educational Research, 16, 163-171.

Reerink, E., Tiddens, H.A., \& Wijnen, W.H.F.W. (1974). Maastricht en McMaster. Meta Medica, 10, 214-256.

Rodger, I. (1983). The influence of examinations. In K.G. Collier, (Ed.), The management of peer group learning. Syndicate methods in Higher Education. (pp. 87-92) Guilford: Society for Research into Higher Education.

Rosenbaum, P.S. (1973). Peer mediated instruction. New York: Teachers College Press.

Rudduck, J. (1978). Learning through small group discussion. A study of seminar work in higher education. Guilford: Society for Research into Higher Education.

Rumelhart, D.E., \& Norman, D.A. (1978). Accreation, tuning and restructuring: Three modes of learning. In J.W. Cotton \& R.L. Klatzky (Eds.), Semantic factors in cognition. Hillsdale (N.J.): Lawrence Erlbaum Ass.

Sarbin, T.R. (1976). Cross-age tutoring and social identity. In V.L. Allen (Ed.), Childern as teachers. (pp. 27-40). New York: Academic Press.

Saris, W.E., \& Stronkhorst, L.K. (198.). Causal modeling in nonexperimental research. An introduction to the Lisrel approach. Amsterdam: Sociometric Research Association.

Schermerhorn, S.M., Goldschmid M.L., \& Shore B.M. (1976). Peer teaching in the classroom: Rationale and feasibility. Improving Human Performance Quaterly, 5, 1, pp. 27-34.

Schoenfeld, A.H. (1989) Ideas in the air: Speculation on small-group learning, environmental and cultural influencies on cognition and epistemology. International Joumal of Educational Research, 13, 71-88.

Schmidt, H.G. (1979). Leren met problemen. Een inleiding in probleemgestuurd onderwijs. In A.G. Vroon (red.), Handboek voor de onderwijsprakıijk. (pp. Sch 3.4.1. - 3.4. 29). Deventer: Van Loghum Slaterus.

Schmidt, H.G. (1981). Enkele cognitieve effecten van probleemgestuurd onderwijs. In H.G. Schmidt, (red.), Probleemgestuurd onderwijs. (pp. 9-29). Harlingen: Flevodruk.

Schmidt, H.G. (1982). Activatie van voorkennis, intrinsieke motivatie en de verwerking van tekst. Studies in probleemgestuurd onderwijs. Apeldoom: Van Walraven BV.

Schmidt, H.G. (1983). Problem-based learning: Rationale and description. Medical Educaiion, 17, 11-16.

Schmidt, H.G., \& Bouhuijs, P.A.J. (1980). Onderwijs in taakgerichte groepen. Utrecht: Het Spectrum.

Schmidt, H.G., Foster, S. \& Bouhuijs, P.A.J. (1989). Theoretische en empirische grondslagen van probleemgestuurd onderwijs. In P. Keizer, (red.), Probleemgestuurd onderwijs in de economische wetenschap. (pp. 11-31). Assen: Van Gorcum.

Schmidt, H.G., \& Gijselaers, W.H. (1990). Causal modelling of problem-based learning. Paper presented at the Annual Meeting of the American Educational Research Association, Boston, M.A.

Sharan, S. (1980). Cooperative learning in small groups: Recent methods and effects on achievement, attitudes and ethnic relations. Review of Educational Research, 50, 241 247.

Sharan, S. (1984). Cooperative learning. Hillsdale, NJ: Erlbaum. 
Shavelson, R.J., \& Webb, N.M. (1991). Generalizability theory: A Primer. London: Sage Publications.

Shuell, T.J. (1986). Cognitive conceptions of learning. Review of Educational Research, $56,4,411-436$.

Shuell, T.J. (1988). The role of the student in learning from instruction. Contemptrary Educational Psychology, 13, 276-295.

Shulman, L.S., \& Keislar, E.R. (Eds.), (1966) Learning by discovery, a critical appruisal. Chicago: Rand Mc Nally.

Silver, M., \& Wilkerson, L. (1991). Effects of tutors with subject expertise on the problem-based tutorial process. Academic Medicine, 66, 6, 298-300.

Slavin, R.E. (1980). A review of peer tutoring and cooperative learning in twenty-eight schools. Review of Educational Research, 11, 315-342.

Slavin, R.E. (1989). Cooperative learning and student achievement. In R.E. Slavin (Ed.) School and classroom organization. (pp. 129-159). Hillsdale: Lawrence Erlbaum Associates.

Slotnick, R.S., Jager, A.M., \& Schure, M. (1981). Peer support networks in a large introductory psychology class. Paper presented at the American Psychology Association National Convention, Los Angeles. Geciteerd in N.A. Whitman, (1988) Peer teaching: To teach is to learn twice. ASHE-ERIC Higher Education Report No. 4. Washington, D.C.: Association for the Study of Higher Education.

Smith, R., Feletti, G., \& Hughes, J. (1986). Can senior students be good small-group tutors? Higher Education Research \& Development Society of Australia News, 8, 7-8.

Thung, P.J. (1980). Rechten in Maastricht. Rapport van de Voorbereidingscommissie Juridische Studierichting. Leiden.

Tober, H.J. (1985). Vergelijking van tijdschrijf- en schattingsgegevens. In A. Bax, (red.). Verslag van de CRWO-studiedag 1984. (pp. 183-196). Den Haag: CBOWO/Academische Raad.

Topping, K. (1988). The peer tutoring handbook. London: Croom Helm.

Trakman, L.E. (1979). Law student teachers: An untapped resource. Joumal of Legal Education, 30, 331-357.

Tucker, L.S., \& Lewis, C. (1973). The reliability coefficient for maximum likelihood factor analysis. Psychometrika, 38, 1-10.

Volder, M.L. de, Grave, W.S. de, \& Gijselaers, W.H. (1985). Peer teaching: Academic achievement of teacher-led versus student-led discussion groups. Higher Education, $14,643-650$.

Wagner, L. (1982). Peer Teaching. Historical Perspectives. London: Greenwood Press.

Warries, E. (1977). Jerome Bruner. In Q. Meer, van der, \& H. Bergman, (red.), Onderwijskundigen van de twintigste eeuw. (pp. 211-226). Groningen: Wolters-Noordhoff.

Webb, G. (1983). The tutorial method. Learning strategies and student participation in tutortials: Some problems and suggested solutions. Programmed Learning and Educational Technology, 20, 117-121.

Webb, N.M. (1982). Student interactions and learning in small groups. Review of Educational Research, 52, 421-445.

Webb, N.M. (1989). Peer interaction and learning in small groups. International Journal of Educational Research, 13, 21-41.

Weiner, M. (1990). Improving college teaching. San Fransisco: Jossey-Bass Publ.

White, J.R. (1945). Methods in engineering laboratory instruction. Joumal of Engineering Education, 35, 50-54. 
Whitman, N.A. (1988). Peer teaching: To teach is to learn twice. Washington D.C.: ASHE - ERIC Higher Education Report No 4.

Wilkerson, L. (1992). Identification of skills for the problem-based tutor: student and faculty perspectives. Paper presented at the Annual Meeting of the American Educational Research Association. San Francisco, Cal.

Wittrock, M.C. (1966). The learning by discovery hypothesis. In L.S. Shulman, \& E.R. Keislar, (Eds.), (pp. 33-76). Learning by discovery, a critical appraisal. Chicago: Rand Mc Nally.

Wittrock, M.C. (1986). Handbook of Research on Teaching. New York: MacMillan.

Wolleswinkel, R. (1989). Studeren in een probleemgestuurd curriculum. In M.J. Cohen (red.), Ervaringen met probleemgestuurd onderwijs. (pp. 21-35). Deventer: Kluwer. 


\section{BIJLAGE 3.1}

Aan: Deelnemers van het onderwijs in de blokken "Rechtshandeling" en "Onrechtmatig gedrag".

Betreft: Uw medewerking aan een onderzoek naar de invloed van onderwijsgroepen op leerprestaties

Geachte student(e),

Misschien heeft $U$ in het afgelopen nummer van de Observant (no. 10), het uitvoerige artikel over de tutor in het Maastrichtse onderwijs gelezen. Uit dat artikel blijkt dat het nog niet zo gemakkelijk is om te bepalen aan welke eisen zo'n tutor moet voldoen. U begint daar misschien zelf, zo tijdens uw tweede blok, ook al ideeën over te krijgen.

Hoe dan ook, in de juridische faculteit gaat in de tweede helft van dit jaar, gedurende de blokken 1.3 en 1.4 een onderzoek van start, dat ons iets moet leren over de invloed van onderwijsgroepen op leerprestaties. $U$ begrijpt dat het een onderwerp is, dat voor het onderwijs binnen deze faculteit van groot belang is. Vragen die in dit onderzoek centraal zullen staan, zijn onder meer: wat is nu precies de invloed van de onderwijsgroep op leerprestaties en maakt het daarbij veel uit op welke manier de tutor zijn of haar rol uitvoert? Welke andere factoren spelen bij het bereiken van leerresultaten een rol? Wat is de invloed van de hoeveelheid aan studie bestede tijd?

Het spreekt vanzelf dat wij voor dit onderzoek afhankelijk zijn van uw medewerking: U bent tenslotte degene die aan dat onderwijs deelneemt en die leerprestaties levert. We hebben uw medewerking nodig voor:

a. het (in januari) invullen van een korte toets met vragen over onderwerpen die in blok 1.3 en 1.4 aan de orde zullen komen;

b. het invullen, aan het einde van de blokken 1.3 en 1.4 , van een vragenlijst over het funktioneren van uw onderwijsgroep;

c. het gedurende de blokken 1.3 en 1.4, dagelijks bijhouden van de door $\mathrm{U}$ aan studie bestede tijd. Dit laatste lijkt veel werk, maar bestaat uit niet meer dan het dagelijks noteren van de door $U$ aan studie bestede tijd en het wekelijks terugzenden van een formulier. Het is mogelijk dat $\mathrm{U}$ hiervoor een kleine financiële vergoeding ontvangt.

Als gezegd is dit onderzoek voor het funktioneren van het onderwijs aan de faculteit heel belangrijk. Maar dat betekent niet, en ik wijs daar met nadruk op, dat de faculteit inzage krijgt in de individuele gegevens die verzameld worden. In de rapportages aan de faculteit wordt uitsluitend en alleen gesproken en geschreven over groepstotalen. Uw anonimiteit wordt absoluut gewaarborgd. 
Wilt U meer weten over dit onderzoek, dan kunt $U$ mij bereiken via het secretariaat van de vakgroep Metajuridica (Nieuwenhof, k. 0041, tel. 887020) of door een briefje te sturen naar:

Jos Moust,

vakgroep Onderwijsontwikkeling en -research,

RL 


\section{BIJLAGE 3.2}

Aan: Alle eerstejaarsstudenten

Betreft: Onderzoek naar de kwaliteit van het onderwijs in de blokken 1.3 en 1.4

Maastricht, 8 december 1988

Beste student(e),

Onlangs is via mondelinge mededelingen en het publikatiebord voor eerstejaars melding gemaakt van een onderzoek naar de kwaliteit van het onderwijs in de blokken "Rechtshandeling" (1.3) en "Onrechtmatig gedrag" (1.4).

Via deze brief wil ik $U$ verder informeren over dit onderzoek en $U$ vragen aan dit onderzoek mee te willen doen.

Zoals $U$ weet zijn we nog een jonge faculteit die probeert via een ander onderwijsprogramma en een nieuwe vormgeving de rechtenstudie op een boeiende wijze vorm en inhoud te geven.

De verschillende geledingen in de faculteit proberen voortdurend de kwaliteit van het onderwijs op diverse manieren te bewaken en te verhogen. Een dergelijke omvangrijke verandering van het onderwijs vereist voortdurend informatie over de wijze waarop het programma en de onderwijsmethode in de praktijk werkt. Om adekwaat te kunnen bijsturen op punten waar het niet optimaal verloopt is informatie nodig.

Om deze informatie te verkrijgen wil de faculteit gedurende de blokken 1.3 en 1.4 onderzoek doen naar de kwaliteit van het onderwijs in die blokken.

Dit onderzoek bestaat uit de volgende onderdelen:

1. alle eerstejaarsstudenten worden gevraagd mee te doen aan een korte toets, bestaande uit ongeveer 60 à 70 vragen. Deze toets wordt afgenomen tijdens de eerste practicumbijeenkomst van blok 1.3 (Rode Kluwer of Vermande s.v.p. meenemen);

2. een deel van de studenten wordt verzocht, tijdens blok 1.3 en 1.4 mee te doen aan een onderzoek naar de wijze waarop de studietijd besteed wordt. Dit onderzoek bestaat uit het wekelijks invullen van een formuliertje waarop vermeld moet worden hoeveel uren per week besteed wordt aan zelfstudie en onderwijsdeelname;

3. alle eerstejaarsstudenten worden verzocht, na afloop van bovengenoemde blokken, een vragenlijst in te vullen over de verschillende onderwijselementen die plaatsvonden tijdens de blokperiode;

4. een deel van de studenten zal, gedurende beide blokken, gevraagd worden deel te nemen aan een kort interview over hun ervaringen met probleemgestuurd onderwijs. 
In totaal zal uw bijdrage aan dit onderzock gedurende het komende halve jaar ongeveer 3 tot 6 uur tijd in beslag nemen, afhankelijk van de onderdelen waaraan $U$ mee doet.

Het onderzoek zal worden uitgevoerd door ondergetekende, lid van de vakgroep Onderwijsontwikkeling en -research.

Voor de betrouwbaarheid van de gegevens is het erg belangrijk dat iedereen meedoet. Hoewel het onderzoek niet in volledige anonimiteit kan plaatsvinden (sommige gegevens moeten aan elkaar gekoppeld kunnen worden) is met de faculteit afgesproken dat deze géén individuele gegevens over studenten krijgt. Zij krijgt uitsluitend en alleen groepstotalen.

Waarom zou U eigenlijk meedoen aan dit onderzoek? Ten eerste omdat U zodoende gelegenheid krijgt invloed uit te oefenen op het onderwijs dat $U$ geniet. Ten tweede omdat $U$ de faculteit helpt de kwaliteit van haar onderwijs te verbeteren. Daarbij hebben zowel $U$ als de Faculteit baat. En, ten derde, omdat $U$ daarmee de faculteit helpt instrumenten te ontwikkelen die geschikt zijn om blijvend aan kwaliteitstoetsing te doen. Uiteraard krijgt $\mathrm{U}$ de bevindingen van dit onderzoek te horen.

We rekenen op uw medewerking!

Met vriendelijke groet,

Jos Moust

vakgroep Onderwijsontwikkeling en -research

RL

N.B. Voor verdere informatie, mededelingen etc. ben ik bereikbaar via het secretariaat van de vakgoep Metajuridica, km 045 in de Nieuwenhof (tst. 7020) of via km. 1045 Nieuwenhof, tst. 7064 
BIJLAGE 4.1

\section{Generaliseerbaarheidsstudie bloktoetsen}

Bijlage 4.I.a

Decisiestudie van de bloktoets "Rechtshandeling"

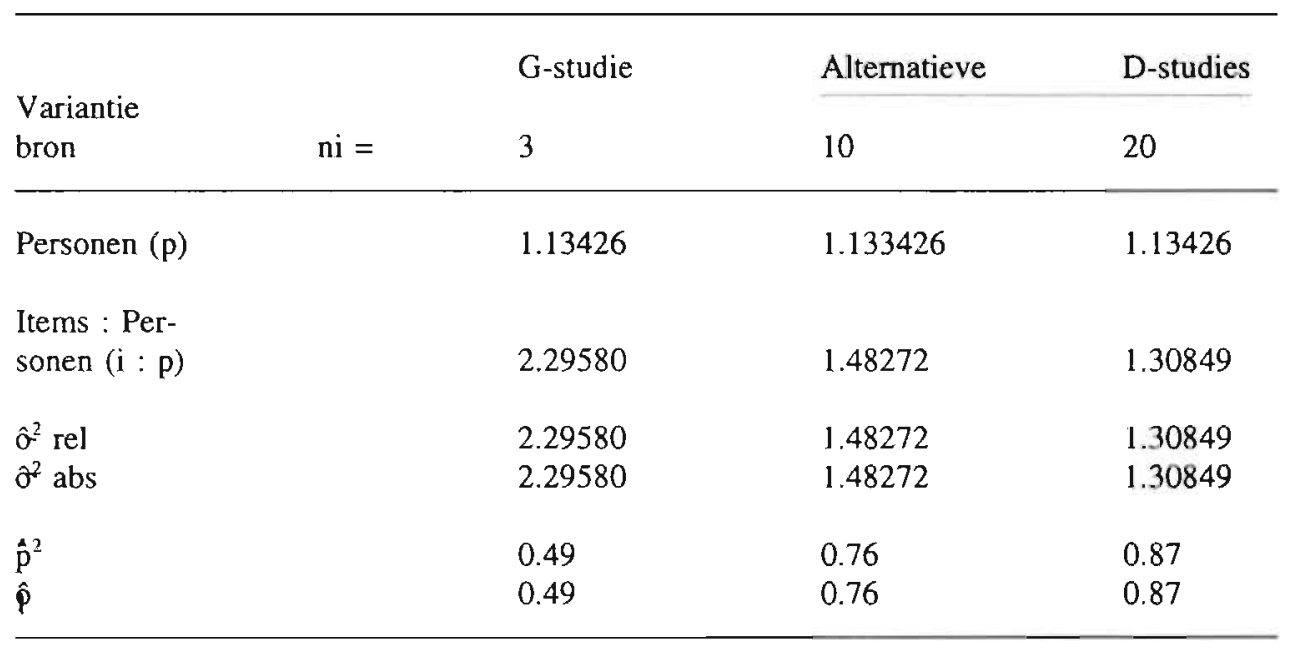


Bijlage 4.l.b

Decisiestudie van de bloktoets "Onrechtmatig gedrag"

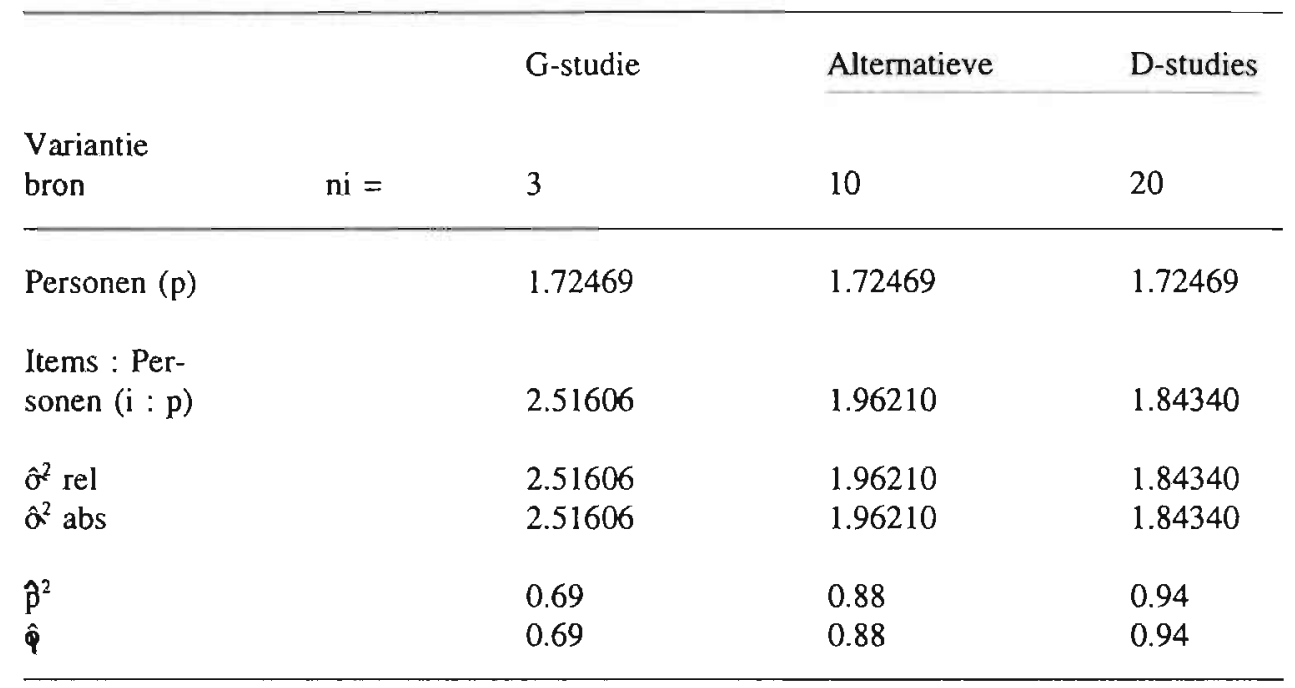


Gemiddelde aantallen totale proposities (T-prop), juiste proposities (J-prop), descriptieve proposities (D-prop) en verklarende proposities (V-prop) (met standaarddeviaties) op vraagniveau van alle bloktoetsvragen blok "Rechtshandeling"*

vraag 1

\begin{tabular}{lllllllll} 
& T-prop & \multicolumn{3}{c}{ J-prop } & \multicolumn{3}{c}{ D-prop } & \multicolumn{2}{c}{ V-prop } \\
& $X^{N}$ & SD & X & SD & X & SD & X & SD \\
10 & 43 & 17 & 28 & 14 & 5 & 3 & 24 & 12 \\
10 & 32 & 11 & 25 & 10 & 6 & 5 & 19 & 10 \\
\hline
\end{tabular}

vraag 2

\begin{tabular}{|c|c|c|c|c|}
\hline & T-prop & J-prop & D-prop & V-prop \\
\hline$N$ & SD & SD & SD & $X$ \\
\hline
\end{tabular}

\begin{tabular}{llllllllll} 
staflid-tutor & 10 & 39 & 18 & 31 & 17 & 6 & 4 & 25 & 13 \\
student-tutor & 10 & 37 & 15 & 27 & 14 & 6 & 4 & 21 & 11 \\
\hline
\end{tabular}

vraag 3

\begin{tabular}{|c|c|c|c|c|}
\hline & T-prop & J-prop & D-prop & V-prop \\
\hline $\mathrm{N}$ & SD & SD & $S D$ & $\mathrm{X}$ \\
\hline
\end{tabular}

\begin{tabular}{llllllllll} 
staflid-tutor & 10 & 29 & 14 & 21 & 12 & 3 & 3 & 17 & 9 \\
student-tutor & 10 & 35 & 14 & 25 & 13 & 6 & 4 & 19 & 9 \\
\hline
\end{tabular}

vraag 4

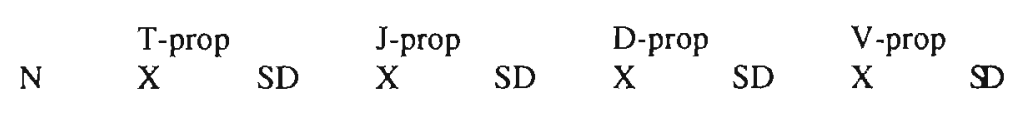

\begin{tabular}{lllllllllll} 
staflid-tutor & 5 & 31 & 17 & 20 & 14 & 1 & 1 & 19 & 13 \\
student-tutor & 3 & 38 & 26 & 24 & 15 & 2 & 2 & 22 & 13 \\
\hline
\end{tabular}


vraag 5

\begin{tabular}{llllllllll} 
& & T-prop & \multicolumn{3}{c}{ J-prop } & \multicolumn{1}{c}{ D-prop } & \multicolumn{2}{c}{ V-prop } \\
& $\mathrm{N}$ & $\mathrm{X}$ & $\mathrm{SD}$ & $\mathrm{X}$ & $\mathrm{SD}$ & $\mathrm{X}$ & $\mathrm{SD}$ & $\mathrm{X}$ & $\mathbf{S}$ \\
& & & & & & & & & \\
staflid-tutor & 10 & 27 & 10 & 21 & 8 & 2 & 1 & 20 & 8 \\
student-tutor & 10 & 37 & 13 & 25 & 12 & 2 & 1 & 23 & 11 \\
\hline
\end{tabular}

* Verschillen tussen gemiddelden die in Bijlage 4.2 zijn weergegeven werden getoetst door middel van variantie analyse (ANOVA). De resultaten wijzen uit dat er geen significante verschillen $(p>.05)$ zijn tussen studenten begeleid door staf-tutoren en studenten begeleid door student-tutoren. 
Gemiddelde aantallen totale proposities ( $T$-prop), juiste proposities (J-prop), descriptieve proposities ( $D$-prop) en verklarende proposities (V-prop) (met standaarddeviaties) op vraagniveau van alle bloktoetsvragen blok "Onrechtmatig gedrag"*

vraag 1

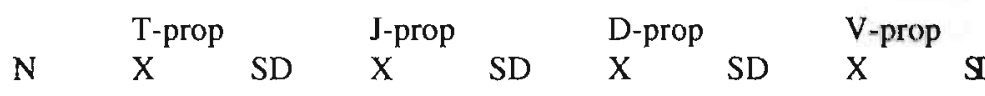

\begin{tabular}{llllllllll} 
staflid-tutor & 15 & 35 & 10 & 23 & 11 & 8 & 7 & 15 & 10 \\
student-tutor & 15 & 38 & 14 & 25 & 11 & 6 & 4 & 19 & 9 \\
\hline
\end{tabular}

vraag 2

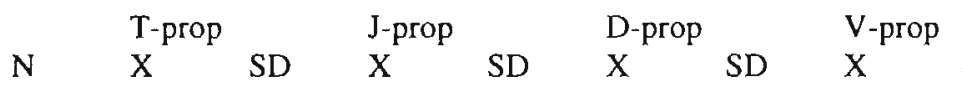

\begin{tabular}{llllllllll} 
staflid-tutor & 15 & 35 & 12 & 17 & 10 & 3 & 3 & 14 & 9 \\
student-tutor & 15 & 32 & 9 & 18 & 9 & 2 & 2 & 16 & 8 \\
\hline
\end{tabular}

vraag 3

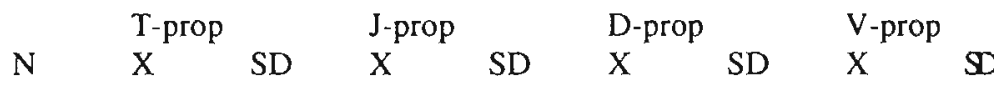

\begin{tabular}{llllllllll} 
staflid-tutor & 14 & 30 & 14 & 20 & 12 & 2 & 3 & 18 & 11 \\
student-tutor & 14 & 30 & 7 & 20 & 9 & 1 & 1 & 19 & 9 \\
\hline
\end{tabular}

vraag 4

$\begin{array}{lllllll} & \text { T-prop } & & \text { J-prop } & & \text { D-prop } & \\ \text { X-prop }\end{array}$

$\$$

\begin{tabular}{llllllllll} 
staflid-tutor & 15 & 35 & 8 & 24 & 9 & 4 & 3 & 20 & 10 \\
student-tutor & 15 & 37 & 8 & 23 & 9 & 3 & 2 & 20 & 9 \\
\hline
\end{tabular}


vraag 5

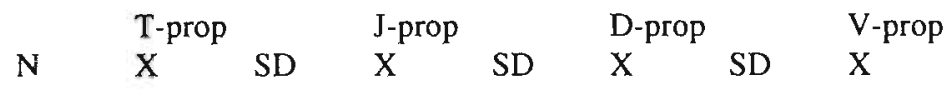

SD

\begin{tabular}{llllllllll} 
staflid-tutor & 15 & 32 & 9 & 21 & 8 & 3 & 2 & 18 & 9 \\
student-tutor & 15 & 32 & 12 & 19 & 12 & 3 & 2 & 17 & 12 \\
\hline
\end{tabular}

* Verschillen tussen gemiddelden die in Tabel 15 zijn weergegeven werden getoetst door middel van variantie analyse (ANOVA). De resultaten wijzen uit dat er geen significante verschillen $(p>.05)$ zijn tussen studenten begeleid door staf-tutoren en studenten begeleid door student-tutoren. 


\section{BIJLAGE 5.1}

FORMULIER TIJDSEESTEDING BLOK. 1.4 week: $7(22 / 5-29 / 5)$

Naam en voorletters:

Adres (1):

tel
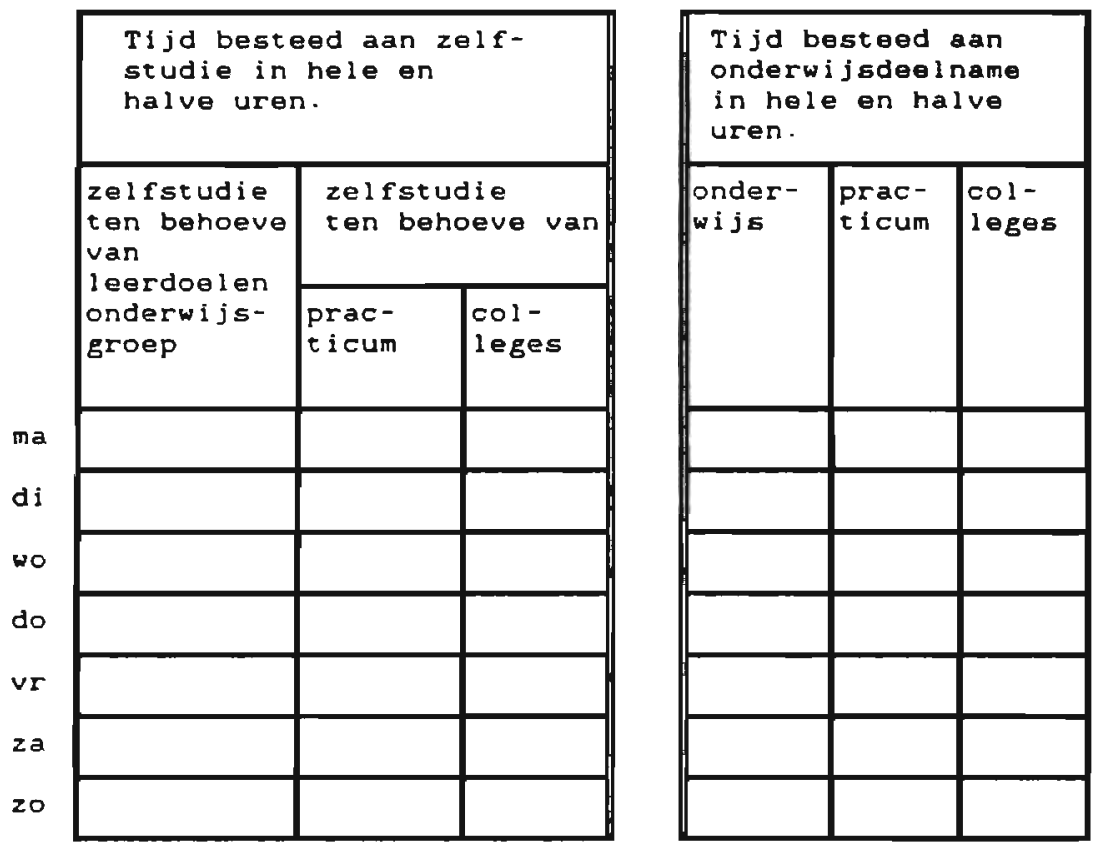

1. alleen invullen als adres gewijzigd is of gedurende het blok gaat wijzigen.

2. voorbeelden van $t$ ijdsinvulling:

a: studietijd leerdoelen onderwijsgroep 2 uur en 15 minuten $=2$ uur

b: practicumtijdsduur 2 uur en 20 minuten $=21 / 2$ uur

c: college van 1 uur en 40 minuten $=11 / 2$ uur

d: studie voor practicum van 2 uur en $50 \mathrm{~min}$. = 3 uur

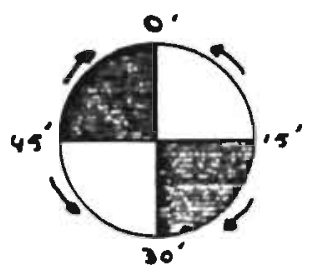




\section{BIJLAGE 5.2}

Aan de deelnemers van het onderwijs in het blok "Rechtshandeling", Faculteit der Rechtsgeleerdheid

Beste student(e),

Deze brief en de bijgevoegde formulieren vormen het begin van het TLJDSCHRIJFONDERZOEK, dat ik onlangs (brief, dd. ) en afgelopen week al mondeling bij u aankondigde. Ik herhaal nog eens kort wat het doel van dit onderzoek is en leg u vervolgens de werkwijze uit.

Een van mijn taken in de Faculteit der Rechtsgeleerdheid is het ondersteunen en verder uitbouwen van probleemgestuurd onderwijs. Hiermee houd ik mij op verschillende manieren bezig: ik probeer het functioneren van onderwijsgroepen te verbeteren (zie bv. de Handleiding Probleemgestuurd Studeren) en ik verzorg kursussen voor tutoren en planningsgroepsleden. Een van mijn andere aktiviteiten in de Faculteit is het uitvoeren van onderwijskundig onderzoek. Via deze werkzaamheden probeer ik een bijdrage te leveren aan het verbeteren van de kwaliteit van het onderwijs dat de staf van deze Faculteit u levert.

In het blok "Rechtshandeling" wil ik via onderzoek meer inzicht vergaren in het funktioneren van onderwijsgroepen en de invloed die daarvan op uw studie-activiteiten uitgaat. Om daar achter te komen vragen we u dagelijks bij te houden hoeveel uren $u$ aan uw studie besteedt. Dat kunt u doen op speciale formulieren, waarvan de eerste drie, bestemd voor de eerste drie weken, zijn bijgesloten.

De formulieren zien er welllicht wat ingewikkeld uit maar het is heel eenvoudig. Als u het formulier voor de eerste week erbij neemt, kan ik u uitleggen hoe het gaat. Links staat een groot vierkant, verdeeld in hokjes. Van boven naar beneden staan de dagen van de week (maandag $\mathrm{t} / \mathrm{m}$ zondag). Van links naar rechts de studie-activiteiten (de verklaring van de afkortingen staan rechtsboven op het formulier). Dit grote vierkant dient ervoor om op te geven hoeveel tijd per dag en ten behoeve van welke onderwijsactiviteit u aan ZELFSTUDIE besteedt. Hebt u bv. op maandagmorgen gestudeerd aan leerdoelen voortvloeiend uit taken uit het blok "Rechtshandeling", dan zet u in het hokje linksboven, hoeveel tijd u daaraan besteed hebt, afgerond in hele en halve uren, (bv. 2 1/2 uur). Heeft u daarentegen bv. 2 uur besteed aan voorbereiding op het practicum in blok 1.3 dan vult u die tijd in in het middengedeelte van het ZELFSTUDIEBLOK.

Rechts van dit zelfstudieblok treft $u$ een ander blok aan, het zgn. ONDERWIJSAANBODBLOK. Hierin kunt u aangeven welke onderwijsactiviteiten u gevolgd heeft die de Faculteit aanbiedt, bv. onderwijsgroepen, practica, lezingen, colleges.

Dit dient eveneens te gebeuren in tijdsperioden van hele en halve uren. Het is wellicht overbodig om op te merken dat wanneer u bv. eens een onderwijsgroepsbijeenkomst niet heeft gevolgd, u deze tijd niet moet noteren. 
Op het moment dat u deze brief ontvangt is de eerste week van deze blokperiode al bezig. Toch krijgt u een formulier voor deze week. We hopen dat u de tijden nog uit uw herinnering kunt invullen. Wat betreft onderwijsalanbodtijd zal dit wel lukken, de zelfstudietijd zal wellicht wat moeilijker zijn. Vanaf de komende week echter kunt u dagelijks precies bijhouden wat u doet. Doe dat ook aan het einde van iedere dag. Dat is dagelijks een heel klein werkje als u het formulier op uw werktafel laat liggen. Aldus krijgen wij de meest betrouwbare gegevens.

De betrouwbaarheid van het onderzoek hangt af van de mate van deelname aan het onderzoek en de correctheid van uw gegevens. We willen graag dat iedereen meedoet. Voor ons onderzoek is even erg als niet-meedoen, het verschaffen van foutieve gegevens verschaffen. $U$ hebt er geen enkel belang bij om meer of minder werkuren op te geven dan u in werkelijkheid maakt. Uw individuele gegevens komen uiteraard niet in handen van de Faculteit. Die is alleen geïnteresseerd in gegevens omtrent de gehele groep; zij krijgt uitsluitend en alleen groepstotalen.

Als dat zo is, waarom staat uw naam dan op het formulier? Dat is nodig om de gegevens per deelnemer over de verschillende weken bij elkaar te houden. Van u wordt namelijk gevraagd aan het begin van iedere nieuwe week het formulier in te leveren. U sluit het formulier in de daartoe verstrekte enveloppe en deponeert hem in de bussen die voor dat doel staan bij de portiers van de lokaties Nieuwenhof en Bouillonstraat.

Om de twee weken ontvangt u een nieuw formulier voor de volgende weken. Ontbreken er oude formulieren van $u$, dan wordt $u$ daaraan herinnerd. Uw naam is dus tevens nodig om bij te houden of iedereen nog meedoet en om de gegevens per persoon bij elkaar te houden.

Waarom zou u eigenlijk meedoen aan dit onderzoek? Ten eerste omdat u de Faculteit helpt de kwaliteit van het blokgebonden onderwijs te verbeteren. Daarbij hebben zowel u als de Faculteit baat. Hogere kwaliteit van onderwijs verbetert direkt uw positie op de arbeidsmarkt en stelt de Faculteit indirect in staat nieuwe initiatieven op onderwijskundig gebied verder door te voeren en uit te breiden. Ten tweede heeft iedereen die tot aan het einde van het blok trouw meedoet recht op een beloning van fl. ... Als u het zichzelf gemakkelijk makkt en dagelijks uw werkuren invult op de voorgeschreven wijze, dan is dat bedrag gemakkelijk verdiend. Ten slotte zullen we u rapporteren wat de bevindingen van dit onderzoek zijn. Aldus kunt u zien hoe uw studie-inspanningen zich verhouden tot die van uw jaargenoten. Een interessant gegeven lijkt ons.

We rekenen op uw medewerking!

Met vriendelijke groet,

Jos Moust

vakgroep Onderwijsontwikkeling en -research

P.S. Voor verdere informatie, mededelingen etc. ben ik bereikbaar via het secretariaat van de vakgroep Metajuridica, km. 0045 Nieuwenhof (tst. 7020) of via km. 1045 Nieuwenhof. tst. 7064 . 


\section{BIJLAGE 6.1}

Beste student (e),

Bijgaande treft $u$ aan een vragenlijst, waamee $u$ kunt aangeven wat uw mening is over het onderwijs dat $u$ in blok 1.4 gevolgd heeft.

Deze vragenlijst maakt deel wit van het onderzoek "kaliteit van het anderwijs" waarvoor $u$ al een of meerdere bijdragen geleverd heeft. Met deze enquete willen we aan alle studenten vragen hoe het hen vergaan is in dit blok en wat hum oordeel is over de verschillende aspekten van het onderwijsaanbod. Het is van groot belang dat de faculteit een helder zicht heeft op de wijze waarop het programma in de praktijk werkt. De vragenlijst bevat vragen over:

* us algemene indruk van dit blak,

* de turtor,

* het blokboek

* de onderwijsgroep

* de practica

* de lezingen en colleges.

De vragenlijst is niet anonien; wij willen deze gegevens koppelen aan de andere gegevens die wij verzamelen. De faculteit alszodanig krijgt geen inzicht in de gegevens van individuen. Individuele gegevens worden witsluitend voor anderzoeksobeleinden gebruikt.

De vragenlijst bestaat wit gesloten en open vragen. De gesloten vragen kunt u gemakkelijk imullen. U hoeft slechts het betreffende cijfer te amcirkelen dat uw mening weergeeft.

Gebruik is gemaakt van een 5-punts schaal, lopende van 1 tot en met 5, bv. bij de onderstaande bewering

De tutar toande .... enthousiasme voor de anderwerpen van dit blok.

betekenen de schaalscores

$\begin{array}{lllll}1 & 2 & 3 & 4 & 5 \\ \text { in zeer } & \text { in geringe } & \text { sams wel in grote } & \text { in zeer } \\ \text { geringe } & \text { mate } & \text { sams niet mate } & \begin{array}{l}\text { grote } \\ \text { mate }\end{array}\end{array}$

In de vragen is gebruik gemaakt van de mannelijke aanspreekvorm. Uiteraard kunt $u$ waar hij staat zij lezen wanneer dat nodig is.

De eerste resultaten van uv evaluatie van dit blok zullen we tijdens het volgende anderwijsblok presenteren.

Hartelijk dank voor uw medewerking.

Jos Moust

Vakgroep onderwijsontwikkel ing

en Onderwijsresearch

$R L$ 
Examennumer:

VRAGENLTIST BTAR 1.4

(of naam en voorletters)

FUNCTTONEREN ONDERWIJTSRRAPP

$\begin{array}{ll}\text { in zeer } & \text { in zeer } \\ \text { geringe } & \text { grote } \\ \text { wate } & \text { mate }\end{array}$

1. De sfeer in mijn anderwijsgroep was .... plezierig.

$\begin{array}{lllll}1 & 2 & 3 & 4 & 5\end{array}$

2. In de anderwijsgroep werd .... ingegaan

op wat groepsleden inbrachten.

$\begin{array}{lllll}1 & 2 & 3 & 4 & 5\end{array}$

3. Ik heb .... iets geleerd van mijn groepsgenoten.

$\begin{array}{lllll}1 & 2 & 3 & 4 & 5\end{array}$

4. Bet werken in de groep was .... bevorderlijk voor mijn zelfstudie-activiteiten.

$\begin{array}{lllll}1 & 2 & 3 & 4 & 5\end{array}$

5. In de onderwijsgroep was .... aandacht voor het bespreken van nieuwe taken.

6. De bijeenkamsten waren .... prochuktief.

$\begin{array}{lllll}1 & 2 & 3 & 4 & 5\end{array}$

7. In de anderwijsgroep werd .... systematisch gewerkt.

$\begin{array}{lllll}1 & 2 & 3 & 4 & 5\end{array}$

8. In de anderwijsgroep stand de rapportage van resultaten van individuele studie .... centraal.

\section{FUNCTIONEREN VAN DE TUTOR}

9. De tutor kon zich .... verplaatsen in de inhoudelijke prablemen die wij tijdens dit blok tegenkwamen.

10. De bijdragen van de tutor hielpen mij .... vertanden te zien tussen stukjes leerstof. $\quad 1 \quad 1 \quad 2 \quad 3 \quad 4 \quad 5$

11. De tutor verwees .... naar het tutorboek. $\quad \begin{array}{llllll}1 & 2 & 3 & 4 & 5\end{array}$

12. De tutor droeg er .... toe bij dat ik goed voonbereid naar de bloktoets ga.

13. De tutar toonde .... wardering voor ons werk.

14. Door het optreden van mijn tutor had ik ... meite toe te geven dat ik iets niet begreep.

15. De tutor wist .... meer dan wij. 


$\begin{array}{ll}\text { in zeer } & \text { in zeer } \\ \text { geringe } & \text { grote } \\ \text { mate } & \text { mate }\end{array}$

16. De tutor toande .... betrakkenheid bij anze studie.

$\begin{array}{lllll}1 & 2 & 3 & 4 & 5\end{array}$

17. De tutor stelde .... eisen aan de hoeveelheid leerstof die wij geacht werden te bestuderen.

$\begin{array}{lllll}1 & 2 & 3 & 4 & 5\end{array}$

18. Tutoren hebben in het algemeen .... invloed op het leren van studenten.

$\begin{array}{lllll}1 & 2 & 3 & 4 & 5\end{array}$

19. De onderwijsgroep had .... kumnen functioneren zander deze tutar.

$\begin{array}{lllll}1 & 2 & 3 & 4 & 5\end{array}$

20. De tutor was .... gericht op het bestuderen van "weetjes".

$\begin{array}{lllll}1 & 2 & 3 & 4 & 5\end{array}$

21. De tutor had .... begrip voor de problemen die een erstejaars heeft met zijn studie. $\quad \begin{array}{llllllll}1 & 2 & 3 & 4 & 5\end{array}$

22. De tutor makkte .... gebruik van zijn vakinhoudelijke deskundigheid bij het begeleiden van de groep.

$\begin{array}{lllll}1 & 2 & 3 & 4 & 5\end{array}$

23. De bijdragen van de tutar hadden .... invloed op de manier waarop ik buiten de anderwijsgroep gewerkt heb.

$\begin{array}{lllll}1 & 2 & 3 & 4 & 5\end{array}$

24. De tutor was .... erop gericht dat in onze onderwijsgroep relaties gelegd werden tussen diverse anderwerpen wit de leerstof.

$\begin{array}{lllll}1 & 2 & 3 & 4 & 5\end{array}$

25. De tutor had .... belangstelling voor anderwerpen die met anze persocallijke levenssfeer te maken hadden.

$\begin{array}{lllll}1 & 2 & 3 & 4 & 5\end{array}$

26. De tutor heeft .... invloed gehad op de manier waarop ik de leerstof bestudeerd heb.

$\begin{array}{lllll}1 & 2 & 3 & 4 & 5\end{array}$

27. De tutor benadrukte .... het toepassen van reeds opgedane kennis op voorbeelden wit de praktijk.

28. Het was merkbaar dat de tutor .... overzicht had over de leerstof van het blok.

$\begin{array}{lllll}1 & 2 & 3 & 4 & 5\end{array}$


Met de volgende vragen willen we niet zo zeer de mate waarin iets gebeurde tijdens blok nagaan, maar hoevaak bepaalde situaties zich voordeden.

De volgende vragen hebben daaram schaalindeling die steeds loopt van:

1 = nooit

2 = zelden

3 = regelmatig

4 = vaak

$5=$ altijd

29. Ik volde mij in deze anderwijsgroep .... nooit

altijd machteloos.

$\begin{array}{lllll}1 & 2 & 3 & 4 & 5 \\ 1 & 2 & 3 & 4 & 5 \\ 1 & 2 & 3 & 4 & 5\end{array}$

31. De tutor trad .... op als een couderwetse schoolmeester".

32. De tutor verbood ons .... bepaalde onderwerpen te bestuderen met een beroep op zijn vakinhoudelijke deskamdigheid.

$\begin{array}{lllll}1 & 2 & 3 & 4 & 5\end{array}$

33. De tutor cuntroleerde .... of wij ans werk wel gedaan hadden.

$\begin{array}{lllll}1 & 2 & 3 & 4 & 5\end{array}$

34. De tutor leek .... op dezelfde wijze over de stof te denken als wij.

$\begin{array}{lllll}1 & 2 & 3 & 4 & 5\end{array}$

35. De tutar stelde .... begrijpelijke vragen. $\quad \begin{array}{lllllll}1 & 2 & 3 & 4 & 5\end{array}$

36. De tutor had .... door dat we iets niet begrepen.

$\begin{array}{lllll}1 & 2 & 3 & 4 & 5\end{array}$

37. De tutor waarschuwde .... voor de zwaarte van dit blok.

$\begin{array}{lllll}1 & 2 & 3 & 4 & 5\end{array}$

38. De tutor makte .... kleinerende qamerkingen wanneer wij bij de bespneking van een anderwerp "de plank missloegen".

39. De tutar stelde zich vakinhoudelijk .... terughoudend op.

$\begin{array}{lllll}1 & 2 & 3 & 4 & 5\end{array}$

40. De tutor gebruikte .... dezelfde terminologie als wij.

$\begin{array}{lllll}1 & 2 & 3 & 4 & 5\end{array}$

41. De tutar noemde .... anderwerpen die wij woor de bloktoets zeker moesten kennen.

$\begin{array}{lllll}1 & 2 & 3 & 4 & 5\end{array}$

42. De tutor korrigeerde .... verkeerde redeneringen.

43. De tutor slaagde er .... in iets op eenvoudige wijze uit te leggen. 
44. De tutar liet .... blijken dat hij infonmeel kontakt met de groepsleden plezierig vond.

45. De tutar verwees .... naar de zak/slaagcijfers van dit blak in het vorige studiejaar.

$$
\begin{array}{lllll}
1 & 2 & 3 & 4 & 5
\end{array}
$$

46. Ik infonmeerde .... bij medestudenten vit andere groepen wat hun tutor hen aanried te bestuderen.

47. De tutor liet .... weten dat hij van en bepaald anderwerp slecht op de hoogte was.

48. Ik volde mij .... onzeker of de tutar ans wel kon helpen met de leerstof.

49. De tutar vertelde .... iets over zijn eigen studie-ervaringen met de anderwerpen die in dit blok aan de orde kwamen.

50. De tutor toande zich .... bezorgd over de inhoudelijke diepgang van diskussie in de groep.

51. De tutar liet .... merken dat zijn mening de enig juiste was.

$\begin{array}{lllll}1 & 2 & 3 & 4 & 5\end{array}$

52. De tutar stelde in de evaluatie zijn eigen functioneren .... ter diskussie.

53. Ik vroeg .... a an studenten wit andere onderwijsgmepen wat $z i j$ in hun groep bespraken en bestudeerden.

54. De tutor verbeterde ans .... met een beroep op zijn vakinhoudelijke deskundigheid.

55. De tutor had .... aandacht voor het functioneren van de onderwijsgroep.

56. De tutor had .... aandacht voor de wijze warrop de gespreksleiders in hun ral functioneerden.

De tutor evalueerde .... de groepsbijeenkamsten. 


\section{BET BUORBCER}

$$
\begin{aligned}
& \text { in zeer } \\
& \text { geringe } \\
& \text { mate }
\end{aligned}
$$

in zeer

grote

mate

58. Het blakboek sloot .... aan bij mijn voorkennis.

$\begin{array}{lllll}1 & 2 & 3 & 4 & 5 \\ 1 & 2 & 3 & 4 & 5 \\ 1 & 2 & 3 & 4 & 5\end{array}$

59. De taken waren .... duidelijk anschneven.

60. De taken gaven .... aanleiding tot zinnige groepsdiskussies.

61. Ik ben .... tevreden over de inhoud van het blakboek.

62. De taken gaven .... aanleiding tot zelfstudie.

63. De taken boden .... mogelijkheden voor een systematische bespreking in de onderwijsgroep.

64. Het blak bood mij .... inzicht in de strukturx van de vakinhoud(en).

65. Het blakboek gaf mij .... hourvast an te antolekken wat de essentiële leerstofelementen in dit blok zijn.

66. De taken boden .... mogelijkheden tot het formuleren van leerdoelen.

67. De taken vergden .... tijd voor zelfstudie.

68. Ik heb .... iets geleerd van de practicumbijeenkomsten.

69. Ik heb in de practicumbijeenkamsten .... plezierig gewerkt.

70. Ik heb .... iets geleerd van de colleges "Rechtsgeschiedenis".

71. Ik heb van de lezingen, die georganiseerd werden in het kader van het blakboek, .... iets geleend. 
UN ETINDOCRDERL OVER DTT ONDERWIJSRIOK

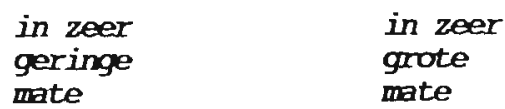

72. Het programma vergde .... studietijd.

$\begin{array}{lllll}1 & 2 & 3 & 4 & 5\end{array}$

73. Ik had .... moite met de leerstof van dit blak.

$\begin{array}{lllll}1 & 2 & 3 & 4 & 5\end{array}$

74. Het blak was .... goed georganiseerd.

$\begin{array}{lllll}1 & 2 & 3 & 4 & 5\end{array}$

75. De leerstof was .... interessant.

$\begin{array}{lllll}1 & 2 & 3 & 4 & 5\end{array}$

76. Ik heb in dit blok .... niewwe dingen geleerd.

$\begin{array}{lllll}1 & 2 & 3 & 4 & 5\end{array}$

77. Ik heb in dit blak .... plezierig gewerkt. $\begin{array}{lllllll}1 & 2 & 3 & 4 & 5\end{array}$

\section{ENRETE AFSLUTTENDE VRAGEN}

78. Hoeveel tijd heeft $u$, gemiddeld gemomen, per week aan literatunirstudie voor de anderwijsgroep besteed?

Vul het antwoord in hele uren in.

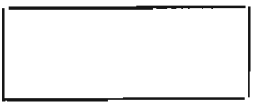

79. Welk percentage van de onderwijsgroepsbijeenkousten van dit blok heeft $u$, naar schatting, gevolgd?

ancirkel uw antwoord.

0 tot/met 248

25 tot/met 498

50 tot/met 758

75 tot/met 1008

80. Als $u$ het totale onderwijs, zoals $u$ het in dit blok meemaakte, glabaal genomen een cijfer zou moten geven op een schaal van 1 tot 10 (zes is cen voldoende), welk cijfer goeft u dan?

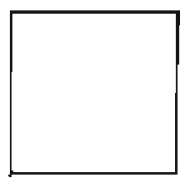


81. Welke aspecten of anderdelen van dit blok zouden veranderd moeten worden?

82. Helke aspecten of anderdelen van dit blak vand $u$ erg goed? 


\section{Generaliseerbaarheidsstudie observatielijst "tutorgedrag"}

Als facetten waarover de variantie werd berekend, werden bepaald:

$\mathrm{T}=$ Tutorvariantie

$I=\quad$ Itemvariantie

$\mathrm{S}: \mathrm{T}=$ Studenten genest binnen tutoren variantie

$\mathrm{TI}=$ Tutoren $\mathrm{x}$ Itemvariantie

IS:T = Items $x$ Studenten genest binnen tutoren variantie (dit is de algemene foutenterm)

Met behulp van ANOVA werden variantiecomponenten en een generaliseerbaarheidscoëfficiënt (voor een enkelvoudige rating) geschat van de mean squares waarbij de standaard procedures van de generaliseerbaarheidstheorie (Brennan, 1983) werd gebruikt. Deze generaliseerbaarheidscoëfficiënt geeft een maat van beoordelaarsbetrouwbaarheid.

Volgens de formule ware variantie

ware variantie + geobserveerde variantie

werden de betrouwbaarheden (generaliseerbaarheden) per schaal berekend.

In dit geval is deze formule

$\mathrm{T}$

$$
T+S: T / n(s)+T V / n(i)+I S: T / n(i) \times n(s)
$$

waarbij $n(s)=$ het aantal studenten $(=5)$ en $n(i)=$ het aantal items per schaal

De gegevens in onderstaande Tabellen geven de variantiekomponenten per schaal weer. 
Geschatte variantiekomponenten per schaal

Blok "Rechtshandeling"

\begin{tabular}{|c|c|c|c|c|c|c|}
\hline \multirow[b]{2}{*}{ Schaal } & \multicolumn{5}{|c|}{ Geschatte variantiekomponenten } & \multirow[b]{2}{*}{ IS:T } \\
\hline & $\begin{array}{l}\text { Aantal } \\
\text { items }\end{array}$ & $\mathrm{T}$ & I & $S: T$ & $\mathrm{TI}$ & \\
\hline Expertise gebruik & 9 & 0,27695 & 0,00585 & 0,00000 & 0,07839 & 0,87345 \\
\hline Cognitieve congruentie & 6 & 0,08137 & 0,01164 & 0,00000 & 0,02964 & 0,56410 \\
\hline Toetsoriëntatie & 3 & 0,14206 & 0,00773 & 0,00000 & 0,00000 & 1,35192 \\
\hline Autoriteit & 5 & 0,14459 & 0,00000 & 0,10019 & 0,13487 & 0,53212 \\
\hline Rolcongruentie & 6 & 0,10323 & 0,00752 & 0,00000 & 0,00000 & 1,23115 \\
\hline Aandacht voor samenwerking & 3 & 0,07989 & 0,01677 & 0,00000 & 0,00000 & 1,20705 \\
\hline
\end{tabular}


Geschatte variantiekomponenten per schaal Blok "Onrechtmatig gedrag"

Geschatte variantiekomponenten

Schaal

Expertise gebruik

Cognitieve congruentie

Toetsoriëntatie

Autoriteit

Rolcongruentie

Aandacht voor samenwerking
Aantal

$\mathrm{T}$

$9 \quad 0,23554$

0,00923

0,00000

0,18684

$6 \quad 0,08149$

0,01108

0,00000

0,03615

$3 \quad 0,07225$

0,00000

0,00000

0,00000

$5 \quad 0,17204$

0,00847

0,09778

0,13375

0,00000

0,09559

0,00000

0,00000
0,82708

0,65648

1,60648

IS:T

0,57222

1,09259

1,07500 

Het schrijven van een proefschrift is een coöperatief leerproces. Op velerlei manieren ben ik door verschillende "peer tutors" en "peer teachers" geholpen, geïnspireerd en gemotiveerd. Het zal mij dan ook niet lukken hen allemaal te bedanken. Ik zou vast en zeker iemand vergeten. Op de eerste plaats wil ik daarom al degenen bedanken wier of wiens naam hier niet genoemd wordt.

Ik wil echter ook enkele mensen uit mijn leer- en leefomgeving graag expliciet dankzeggen. Allereerst mijn collega's aan de juridische faculteit die mij de tijd gaven om aan dit proefschrift te werken ondanks de grote hoeveelheid andere taken die nog plaats moesten vinden.

Voorts, Diana Riksen die geduldig statistische analyses voor mij deed. Petry Thiemann en Elly Peters voor de wijze waarop zij het manuscript van een mooie vormgeving voorzagen. Whitney Bell die de 'summary' nog eens grondig onder handen nam. Leo Claassens die, terwijl hij mij van de tennisbaan veegde, tijdens baanwisselingen mij steeds stimuleerde met de vraag: "Ich weit neet of ich ut vraoge maog, maer wie geit ut mit ut schrieve?".

Ook gaat mijn dank uit naar Wim Gijselaers, Magda Kerkhofs en Cees van der Vleuten die mij bij bepaalde onderdelen van dit proefschrift met hun deskundige raad en daad bijstonden. Tevens wil ik de leden van de beoordelingscommissie bedanken voor hun kritische opmerkingen en suggesties.

Mijn dank gaat vooral uit naar mijn beide promotoren, die mijn vertrouwen om aan deze 'ondememing' te beginnen schraagden met hun adviezen, betrokkenheid en inzet. Job Cohen die, ondanks zijn drukke taken, steeds stip op tijd zijn waardevolle feedback gaf op de verschillende versies van dit proefschrift. Henk Schmidt wiens elaboraties mij steeds weer motiveerde om er nog een schepje bovenop te doen. Henk, jij was een fijne peer teacher en peer-tutor tegelijkertijd. 
Tot slot wil ik Ingnıar. Nina, Björn en Margriet graag nog in het zonnetje zetten. $\mathrm{Na}$ lang aarzelen ben ik aan dit karwei begonnnen. Eén van mijn bedenkingen was dat ik door het schrijven van dit proefschrift, onvoldoende tijd alan jullie zou kunnen besteden. En soms is dat ook het geval geweest. Sorry. Bedankt voor jullie begrip en geduld als ik mij weer eens in mijn werkkamer terugtrok. Hopelijk is er nu weer meer tijd om samen activiteiten te ondernemen. 
Jos Moust werd geboren te Heerlen op 12 augustus 1945. Na het afsluiten van de ULO, studeerde hij aan Pedagogische Academie "Dr. van Gils" te Roermond waar hij in 1967 deze studie afsloot met het behalen van het diploma 'volledig bevoegd onderwijzer'. Na enige jaren les gegeven te hebben aan een lagere school te Bussum, studeerde hij van 1969-1975 aan de faculteit der Sociale wetenschappen van de Katholieke Universiteit te Nijmegen, studierichting Sociale Pedagogiek en Andragogiek. Vervolgens verzorgde hij enkele jaren onderwijs aan de Kader- en Docentenopleiding voor Verpleegkundigen te Rotterdam. Sinds augustus 1978 is hij medewerker bij de vakgroep Onderwijsontwikkeling en Onderwijsresearch van de Rijksuniversiteit Limburg. Zijn speciale aandachtsgebied is onderwijskundige professionalisering van docenten. Momenteel is hij werkzaam bij de Faculteit der Rechtsgeleerdheid. 
